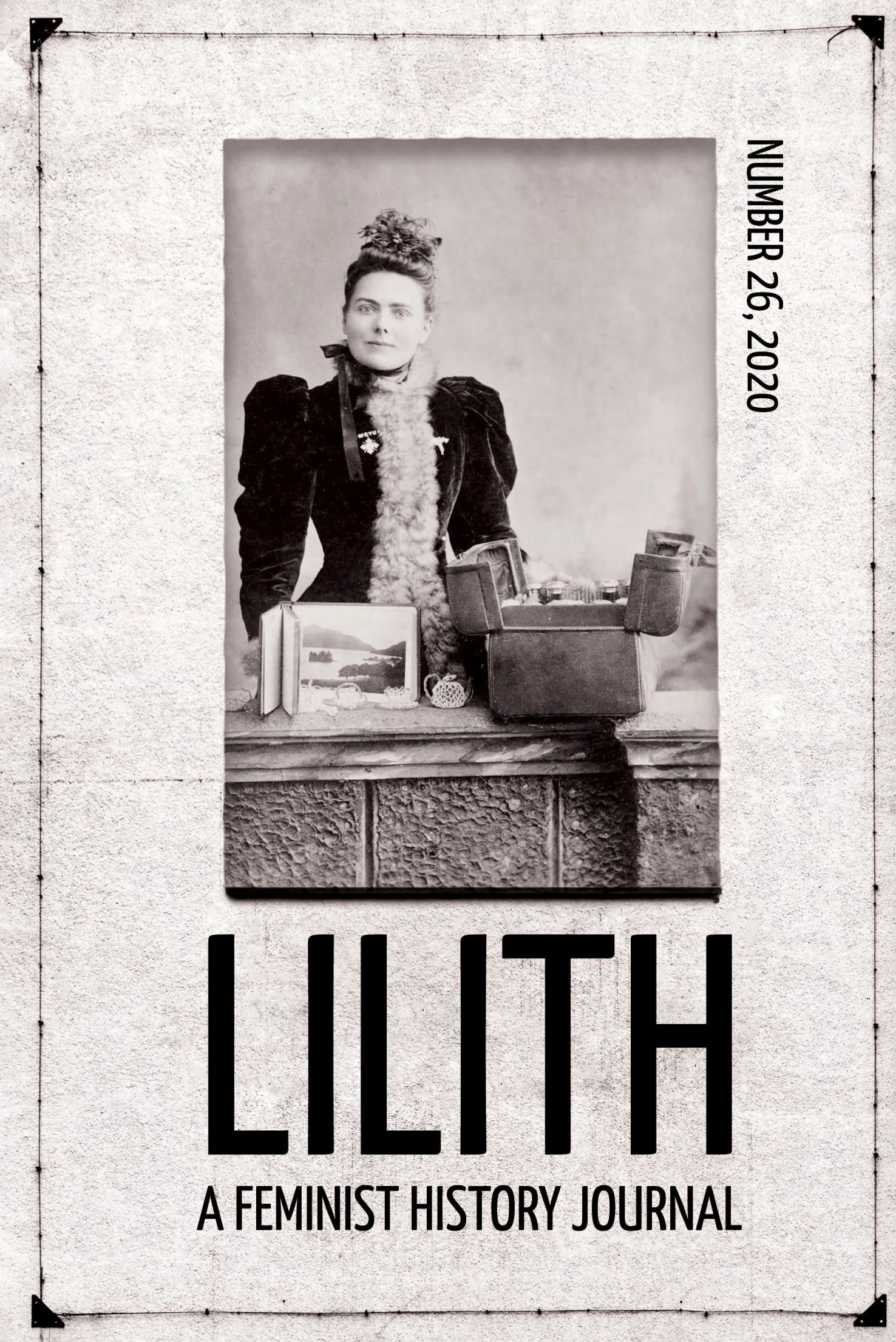





\section{ANU \\ PRESS}

Lilith: A Feminist History Journal is published by ANU Press

The Australian National University

Acton ACT 2601, Australia

Email: anupress@anu.edu.au

This title is available online at press.anu.edu.au

ISSN 2652-8436 (online)

This title is published under a Creative Commons Attribution-NonCommercial-NoDerivatives 4.0 International (CC BY-NC-ND 4.0).

\section{(9) $(\mathcal{Q} \otimes \Theta$}

The full licence terms are available at creativecommons.org/licenses/by-nc-nd/4.0/legalcode

Cover design and layout by ANU Press

Cover photograph: Photograph of Bessie Lee Cowie taken by Yeoman and Company, Melbourne, Australia. Ref: 1/2-007869-F. Alexander Turnbull Library, Wellington, New Zealand. /

records/23156256

(C) 2020 ANU Press

\section{About Lilith}

Lilith: A Feminist History Journal is the journal of the Australian Women's History Network (AUSWHN). First published in Melbourne in 1984, Lilith is a peer-reviewed journal that publishes articles in all areas of women's, feminist and gender history. It is a valuable forum for both new and established scholars. The journal is produced by a collective of postgraduates and early career researchers, along with a distinguished Editorial Advisory Board of leading scholars in the field. New collective members are always welcome. Please contact Lilith (lilithjournal@gmail.com) if you are interested in being part of the team.

\section{Editorial Collective}

Alexandra Ciaffaglione (RMIT University)

Paige Donaghy (University of Queensland)

Dr Rachel Harris (University of Adelaide)

Lauren Samuelsson (University of Wollongong)

Michelle Staff (The Australian National University)

Hannah Viney (Monash University)

\section{Editorial Advisory Board}

Dr Jane Carey (University of Wollongong)

Dr Sharon Crozier-De Rosa (University of Wollongong)

Professor Ann Curthoys (University of Western Australia)

Professor Joy Damousi (University of Melbourne)

Associate Professor Lisa Featherstone (University of Queensland)

Professor Patricia Grimshaw (University of Melbourne)

Professor Victoria Haskins (University of Newcastle)

Dr Catherine Kevin (Flinders University) 
Professor Marilyn Lake (University of Melbourne)

Professor Vera Mackie (University of Wollongong)

Professor Penny Russell (University of Sydney)

Dr Zora Simic (University of New South Wales)

Professor Christina Twomey (Monash University)

Professor Angela Woollacott (The Australian National University)

\section{AUSWHN Journal Manager}

Dr Alana Piper (University of Technology Sydney)

\section{Submissions}

Submissions are due in September each year. Lilith only publishes articles that constitute an original piece of research. Thus it only accepts articles that are not under review by other journals, and that are substantially different from other published work. All articles are peer reviewed, and only articles that pass the review process are published. Lilith will also consider publishing short non-refereed book reviews and discussion essays. Submission guidelines are available at the Lilith website.

\section{Access}

The journal is only available electronically. All back issues are available via the Lilith website. 


\section{LILITH: A FEMINIST HISTORY JOURNAL}

NUMBER 26

\section{Contents}

\section{Editorial}

The Importance of Feminist History in a Global Pandemic. . . . . . . . . . . . . 3 Rachel Harris and Michelle Staff

\section{Articles}

The Theatrics of Protest: Bessie Harrison Lee and Performing the Values of the Woman's Christian Temperance Union . . . . . . . . . . . . . . . . . . 11 Jenny Caligari

Body and Language: Enlivening Exhibitions of Colonial Women in Australian

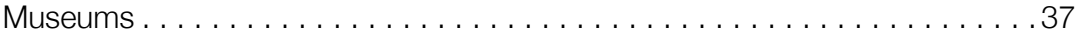

Toni Church

The Mother Archive: Immersion, Affect and the Maternal in Museum Practice

Rebecca Louise Clarke

Women's Politics as Radical Politics: Reconceptualising Women's Historical and Contemporary Political Practices with the Work of Luce Irigaray . . . . . . 81 Belinda Eslick

Religious Dress and the Making of Women Preachers in Australia, 1880-1934.

Kerrie Handasyde

'Laugh and Grow Fat': Resistance, Complicity, Fat Bodies and Community Amongst Rural Women in Interwar Western Australia, 1934-1939 . . . . . . . 121 Jessie Matheson

Female Invisibility in the Male's World of Plantation-Era Tropical North Queensland .143

Bianka Vidonja Balanzategui 
Unnatural Womanhood: Moral Treatment, Puerperal Insanity and the Female Patients at the Fremantle Lunatic Asylum, 1858-1908 . . . . . . . . . 171 Alexandra Wallis

'I Don't Want Anything Like That': The Coercion of British Women and Girls into Domestic Service, 1918-1928 . . . . . . . . . . . . . . . . . . . . 197 Elmarí Whyte

\section{Book Panel}

Debating Patriarchy

Julia Adams, Benita Roth and Pavla Miller

\section{Book Reviews}

Three Lively Feminist Lives

Rosa Campbell

Female Genital Cosmetic Surgery: Deviance, Desire and the Pursuit of Perfection

Paige Donaghy

Notes on Contributors .251 


\section{EDITORIAL}





\title{
The Importance of Feminist History in a Global Pandemic
}

\author{
Rachel Harris and Michelle Staff
}

As we write this editorial, the COVID-19 pandemic is entering its third month. Our everyday lives have drastically changed, requiring us to come to grips with this new normal. In seeking to make sense of the tragedy and immense scale of this global health crisis, parallels have been drawn to other pandemics, particularly the 1919 Spanish flu, which in Australia killed an estimated 12,000 to 15,000 people. ${ }^{1}$ As feminist historians, we are especially interested in the gendered dimensions of pandemics past and present, including how they have impacted women. There is relatively little research on the gendered effects of the 1919 Spanish flu. We do know, however, that nurses, like those on the frontline today, would have been at higher risk of infection. The responsibility to entertain children, at home due to school closures, also fell entirely on women. Moreover, war widows or those with husbands still overseas who became ill were still expected to carry out their caregiving roles. ${ }^{2}$ Almost exactly a century later, the context in which COVID-19 is occurring is vastly different; but there are similarities. Opinion pieces proclaim that its flow-on effects have left women 'anxious, overworked [and] insecure' and that lockdowns are a 'disaster for feminism' as they have placed the burden on women to balance full-time employment with home-schooling and domestic chores. ${ }^{3}$ Household isolation has also led to a worldwide increase in domestic violence, prompting the United Nations to urge governments to 'prevent and redress' violence against women in their pandemic response

1 Frank Bongiorno, 'How Australia's Response to the Spanish Flu Sounds Warnings on Dealing with Coronavirus', Conversation, 22 March 2020, theconversation.com/how-australias-response-tothe-spanish-flu-of-1919-sounds-warnings-on-dealing-with-coronavirus-134017.

2 Humphrey McQueen, 'The "Spanish” Influenza Pandemic in Australia, 1912-19', in Social Policy in Australia: Some Perspectives 1901-1975, ed. Jill Roe (Sydney: Cassell Australia, 1976), 139; Joan Beaumont, Broken Nation: Australians in the Great War (Sydney: Allen \& Unwin, 2013), 523-4. 3 Annabel Crabb, 'Coronavirus has Left Australian Women Anxious, Overworked, Insecure-And Worse Off Than Men Again', ABC News, 24 May 2020, www.abc.net.au/news/2020-05-24/coronavirushas-set-back-progress-for-women-workplace-equality/12268742; Helen Lewis, 'The Coronavirus is a Disaster for Feminism', Atlantic, 19 March 2020, www.theatlantic.com/international/archive/2020/03/ feminism-womens-rights-coronavirus-covid19/608302/. 
plans. ${ }^{4}$ More broadly, it has warned that as a result of COVID-19 and its associated economic impact, 'even the limited gains [towards gender equality] made in the past decades are at risk of being rolled back'. ${ }^{5}$

Women in academia have not been immune. The number of submissions made by women to academic journals in all disciplines in the past month has dropped considerably, while those from men have increased. ${ }^{6}$ Juggling academia and motherhood has always been difficult; for many now it is almost impossible to maintain a competitive research output and tend to children at home all week too. Just yesterday, the University of New South Wales announced the closure of one of its early childhood centres as a result of lost revenue due to a rapid decline in international students-a decision that will disproportionately affect the women who work at and attend the university. ${ }^{7}$ For academic historians more broadly, travel restrictions and the closure of key archives and research institutions will see valuable projects delayed or abandoned. For many, already in precarious positions before the pandemic began, the lack of government support for universities will have an untold impact on career progression. In the midst of these circumstances, feminist history becomes more important than ever as it helps us to understand the structural inequalities that have faced women and others in the past and their significance today. Lilith champions the work of feminist and gender historians, and the publication of this issue during the COVID-19 pandemic is testament to its commitment to the discipline.

The 12 contributions to this issue explore how women have experienced and responded to such inequalities over time, some even flourishing despite them. In them there are evident connections to contemporary discussions surrounding women's status. For example, the response of women leaders, such as New Zealand's Jacinda Ardern and Finland's Sanna Marin, to the

4 'UN Urges Governments to Protect Women from Domestic Violence during Coronavirus Lockdowns', SBS News, 6 April 2020, www.sbs.com.au/news/un-urges-governments-to-protectwomen-from-domestic-violence-during-coronavirus-lockdowns.

5 United Nations, 'Policy Brief: The Impact of COVID-19 on Women', 9 April 2020, www. unwomen.org/-/media/headquarters/attachments/sections/library/publications/2020/policy-briefthe-impact-of-covid-19-on-women-en.pdf?la=en\&vs=1406.

6 Anna Fazackerley, 'Women's Research Plummets During Lockdown but Articles From Men Increase', Guardian, 12 May 2020, www.theguardian.com/education/2020/may/12/womens-researchplummets-during-lockdown-but-articles-from-men-increase.

7 Anna Patty, 'University Childcare Services Axed and Outsourced to Private Operators', Sydney Morning Herald, 26 May 2020, www.smh.com.au/national/nsw/university-childcare-services-axedand-outsourced-to-private-operators-20200526-p54wkm.html. 
COVID-19 pandemic has been much lauded in some quarters, offered as evidence of the effectiveness of women's leadership. ${ }^{8}$ Yet as Belinda Eslick demonstrates, women's political activity still largely exists outside of spaces traditionally considered 'political'. In placing value on the woman who breaks through into the halls of parliament, she argues, we continue to valorise masculine conceptions of politics. Drawing upon the work of Australian historian Marilyn Lake and French philosopher Luce Irigaray, Eslick suggests that women's alternate ways of doing politics should be considered as radical disruptions to the norm and must be seen as legitimate rather than deficient.

How women's lives are memorialised is an important part of ensuring they remain visible and their achievements rightly acknowledged. Toni Church and Rebecca Louise Clarke both consider this issue in relation to Australian museum displays. In a discussion of curatorial practice and methodology, Church advocates that museums must make greater effort to more accurately portray the autonomous voices of colonial Australian women. This is needed in order to make them stand apart from the male actors that have so often shaped public understanding of the frontier and challenge traditional interpretations of their lives. Clarke's article takes an opposing stance as it advocates for the inclusion of women's maternal experiences in museum programs, but at its core also disrupts thinking about traditional museum practice, arguing that museums need to pay more attention to important 'stories of quiet heroism' such as those of mothers, in addition to their traditional focus on grand narratives and national events. Clarke's exploration of the possibilities offered by online storytelling and virtual exhibits take on new relevance as museums explore different ways to stay connected with the public due to their physical closure as a result of the current pandemic.

Several authors also address the depiction and experiences of women's bodies in the past, navigating the intertwined themes of gender and embodiment. Jenny Caligari employs the lens of the individual to focus her analysis, delving into the life of temperance evangelist Bessie Harrison Lee, pictured on the front cover of this issue. She explores Lee's theatricality, dress and public appearances within the context of her activism for women's rights and temperance reform, which sent

8 Louise Champoux-Paillé and Anne-Marie Croteau, 'Why Women Leaders are Excelling During the Coronavirus Pandemic', Conversation, 13 May 2020, theconversation.com/why-women-leadersare-excelling-during-the-coronavirus-pandemic- 138098. 
this working-class woman around the world and into the public eye. The discussion of embodiment and women's dress is picked up again in Kerrie Handasyde's article. Her analysis of women preachers' sartorial choices across three Protestant denominations from the late nineteenth to early twentieth centuries draws upon contemporary periodicals and reveals the multivalent connections between women's clothing, gender, religious visual culture and the authorisation of women's ministry during these years.

As the authors in this issue demonstrate, the human body is not simply a site for the reproduction of cultural norms concerning gender identity and performance. Central to discussions of embodiment are the opposing yet often coexisting concepts of conformity and contestation. Jessie Matheson foregrounds these ideas in her exploration of the fat women who created a community around the women's pages of the Western Mail. She evokes the ambiguity of this space, explaining how the women who wrote letters that appeared in these pages simultaneously challenged and reinforced prevailing cultural narratives about their 'outsized' bodies and feminine ideals. As Elmarí Whyte shows in her article, these themes of conformity and resistance have broader applicability as well. Whyte examines working-class families' complicity in the state coercion of women and girls into domestic service in 1920s Britain. Pointing to economic and moral concerns and using the voices of domestic servants captured in oral histories, she teases out the gendered and class-based dynamics of labour force participation in the aftermath of the First World War to provide a more complex picture of this phenomenon.

The theme of women and domesticity is extended in other contributions to this issue. Bianka Vidonja Balanzategui's article considers the intersection of domestic service and ethnicity in her study of Manbarra (Palm Island) woman Jenny, a late nineteenth-century house servant in the Herbert River Valley, far North Queensland. Her story, alongside that of white women and other women of colour living on the Herbert from the 1870s to the 1890 s, reveals the profound contribution they made to the success of the settlement and aims to rectify the invisibility of women on the frontier, which has hitherto been characterised as a masculine landscape. Shifting geographically to the other side of the country but continuing the theme of nineteenth-century domestic work, Alexandra Wallis examines how women at Fremantle Asylum were prescribed domestic chores as a form of rehabilitation for 'mental derangement' after childbirth. In unearthing this piece of history, Wallis speaks to contemporary concerns regarding 
postnatal depression and clearly demonstrates the potential of feminist history to inform contemporary debates and teach us about women's responses to challenging circumstances in the present.

This issue of Lilith also includes a panel discussion on Pavla Miller's book Patriarchy (2017). The contributors engage with contemporary feminist debates surrounding this oft-invoked concept, including those concerning its history, its usefulness and the ways in which it can be best deployed by feminist scholars. The theme of patriarchy-or, indeed, fighting against it-is taken up in the book reviews included in this issue as well. Paige Donaghy reviews Camille Nurka's study Female Genital Cosmetic Surgery: Deviance, Desire and the Pursuit of Perfection. This book, enacting queer and feminist methodology, charts the history of labiaplasty from classical antiquity to the present day, and discovers how institutions and medical professionals have long tried to wield authority over women and their bodies. Rosa Campell shifts focus to examine three recent auto/ biographies of Australian feminists Germaine Greer, Iola Mathews and Anne Summers. Taken together, Campbell argues these three works offer an interesting and important insight into the personal effect that the Women's Liberation movement had on three women central to its momentum, but suggests these works do not adequately reflect upon or address the intersection of the movement with race and racism-perhaps an avenue for further inquiry.

The research on display in this issue of Lilith engages with a range of questions at the heart of contemporary feminist research and demonstrates the vitality of feminist history writing amongst emerging and established scholars alike. Of course, this publication is the result of an entire community's contributions, creativity and generosity. On behalf of the editorial collective, we would like to extend our sincere thanks to the Lilith editorial board and journal manager, Dr Alana Piper. As always, we have greatly benefited from your experience and guidance. Thanks also must go to the many peer reviewers, both local and international, who kindly lent their time and expertise to enable us to continue publishing high-calibre, original scholarship. Last but not least, congratulations to the authors, who finally get to see their words in print. Publishing a journal is a collaborative endeavour, and we on the collective have greatly enjoyed being part of the wider network that Lilith brings together. 
Frequent readers may note that this year we have moved to a new publisher, ANU Press, and to an open-access model of publishing. This is part of our continued commitment to promoting equity and accessibility within the research community. Lilith's founding editors first published this journal in 1984 , creating a space especially for women's history and feminist scholars. Over three decades later, the journal continues to promote the study of feminist, gender and women's history in ever more expansive terms. The COVID-19 pandemic, alongside the other challenges brought by 2020 , has highlighted the precarious foundations underlying advances made towards gender equality. In the face of these challenges, Lilith maintains a commitment to providing a platform for feminist historical research. In seeking to understand how gender has shaped lives in the past, we hope to stimulate conversations about how we might continue feminist work into the future.

29 May 2020 
ARTICLES 



\title{
The Theatrics of Protest: Bessie Harrison Lee and Performing the Values of the Woman's Christian Temperance Union
}

\author{
Jenny Caligari
}

Deakin University

\section{Abstract}

Australian women's activist, Bessie Harrison Lee (1860-1950) used her body and dress in performative, dynamic and innovative ways. Lee established herself as an integral part of a movement of women who exhibited exceptional stamina for public protest. At the beginning of Lee's career, she joined the Woman's Christian Temperance Union (WCTU) because it matched her ideals of how society could best nurture Christian values in the home and wider community. Many women who spoke in public spaces were educated and considered upper class, whilst Lee's early life was characterised by humble beginnings and lack of formal education. Despite the odds, she rose to prominence as President of the WCTU Footscray branch, Colonial Evangelist and Superintendent of Literature. Temperance or abstaining from alcoholic beverages was a primary goal that the WCTU and Lee promoted over a lifetime in multiple contexts in various continents. I argue that revisiting Lee's life shows us that the WCTU provided the environment for working-class women to move up through the ranks and publicly communicate radical ideas behind the veil of a hyper-conservative organisation. Women in this period, rather than shrinking from attention, utilised it to convey powerful messages for social change. 
Lilith: A Feminist History Journal, Number 26

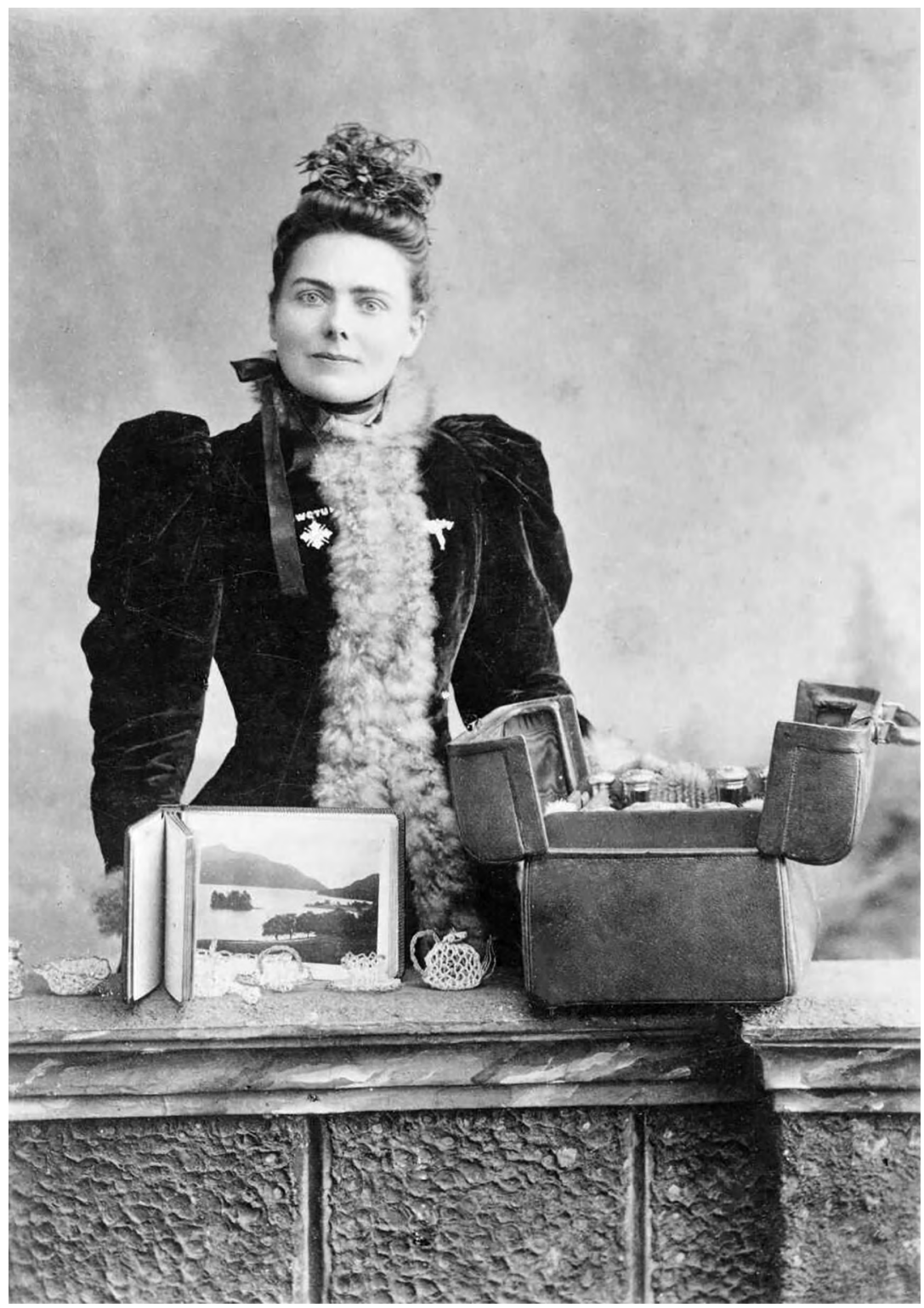

Figure 1: Lee behind a writing desk showcasing gifts from her travels.

Source: Mrs Harrison Lee, Marriage, Heredity and the Social Evil (London: H.J. Osborn, National Temperance Union Depot, 1903). 
Bessie Harrison Lee, a nineteenth-century Australian social activist, placed her image, a robust female body, as a central, exemplary focal point for Christian followers. This occurred from her beginnings as a Sunday School teacher where she would place herself in the middle of a small group of 'bootless, ragged children trundling hoops and playing imaginary cricket'. 'With the combination of her storytelling ability and aptitude for reading her audience, she was honoured in the Australian and British press with such commentary as having 'a clear, penetrating voice, deliberate utterance, kindly humour [which] allowed her to hold an immense audience in eager attention'. ${ }^{2}$ Her appearance, expressed in various media (photography, written publications and speeches), was indicative of her complex ideas about social issues that were marked by sustained activism over a lifetime in numerous forums and countries.

Lee was a significant leader of the late nineteenth-century women's movement in Victoria and internationally. She was born Betsy Vickery on 10 June 1860 in the mining town of Daylesford, Victoria. The town had undergone tremendous changes due to the discovery of gold in the decade prior to her birth. Amidst the backdrop of the profound historical changes to the townspeople of Daylesford, Lee and her siblings were separated after the tragic death of their mother in $1868 .{ }^{3}$ Lee was placed in the care of her aunt and uncle, who resided in the inner-city workingclass suburb of Footscray in Melbourne. During Lee's aunt and uncle's bouts of drunkenness, Lee was subjected to physical abuse. On hearing of Lee's treatment, her father Henry Vickery relocated her to the mining town of Enochs Point. Here she lived with another aunt and uncle who were firm in their deliverance of care, shown by Lee's recollection 'her aunt was unmerciful over any little peccadillo'. ${ }^{4}$ It was during this point that Lee experienced her religious 'conversion'. She believed that 'from that moment I was saved, thy sins are forgiven'. ${ }^{5}$ The mining environment of Enochs Point welcomed evangelical religious fervour as it provided dramatic relief from the dangers associated with mining. ${ }^{6}$ It also explained Lee's comfortable discussion of her personal religious experiences such as

\footnotetext{
1 Bessie Harrison Lee Cowie, One of Australia's Daughters: An Autobiography of Mrs Harrison Lee Cowie (London: James, 1924), 93.

2 'Mrs Harrison Lee', Queensland Times, Ipswich Herald and General Advertiser, 4 July 1903, 12.

3 Cowie, One of Australia's Daughters, 3.

4 Ibid., 30.

5 Ibid., 21.

6 Stuart Piggin, 'Two Spiritual Awakenings, Moonta Mines 1875 and Loddon River 1883', Evangelical Review of Theology, 31, no. 1 (2007): 65.
} 
conversion or 'glorious prayer'. ${ }^{7}$ Julie Melnyk highlighted that 'Evangelical theology', popular amongst mining communities, 'stressed the priesthood of the believer, that is the ability of the individual Christian to interpret God's revelation for himself or herself and to carry on a relationship with God without the intervention of clergy'. ${ }^{8}$ Robert Lee, a young miner, introduced Lee to his brother, a railway worker named Harrison Lee, and they were married at St Peters Anglican Church on 14 March $1880 .{ }^{9}$ Her career's beginnings lay in philanthropic work, specifically volunteering for the poor in refuges and gaols in the inner suburbs of Melbourne. This period of women's participation in charitable activities is reflective of Pamela Walker's observations that 'opportunities for laity, especially women emerged as they did not necessarily require ordination or a formal education'. ${ }^{10}$ When asking her husband whether she should join the Woman's Christian Temperance Union (WCTU), he replied: 'my dear, I think you had better accept the position'. ${ }^{11}$ With her husband's encouragement, Lee helped pioneer the WCTU in Victoria. ${ }^{12}$ The WCTU was an organisation that began in Ohio (USA) with the aim to promote moral character by education and example. ${ }^{13}$ Her public speaking career took Lee through remote rural Victoria, where she travelled by train, boat and horseback to promote a temperance lifestyle. Lee also helped establish the WCTU branch structure, which provided the resources for obtaining some 30,000 signatures for the Monster Petition of 1891 for female suffrage in the colony of Victoria. Besides relentless travel, speechgiving and pledge-taking, she wrote extensively for daily newspapers and the temperance press. In the middle phase of her career, Lee took on a highly visible role as an international campaigner for the World Women's Christian Temperance Union (WWCTU), one of only a few women to achieve this position. Not only did Lee travel abroad to countries such as Britain and the United States of America, she also toured less accessible

\footnotetext{
7 Cowie, One of Australia's Daughters, 38.

8 Julie Melnyk, 'Women, Writing and Theological Cultures', in Women, Gender and Religious Cultures in Britain, 1800-1940, eds. Sue Morgan and Jacqueline deVries (London: Routledge, 2010), 36, doi. org/10.1093/ehr/cer403.

9 Cowie, One of Australia's Danghters, 45.

10 Pamela Walker, 'Women, Preaching and Spiritual Authority', in Women, Gender and Religious Cultures in Britain, 1800-1940, eds. Sue Morgan and Jacqueline deVries (London: Routledge, 2010), 98, doi.org/10.1093/ehr/cer403.

11 Cowie, One of Australia's Daughters, 98.

12 Ibid., 98.

13 Jane Carey and Patricia Grimshaw, 'Woman's Christian Temperance Union of Australia', The Encyclopaedia of Women and Leadership in Twentieth Century Australia, www.womenaustralia. info/leaders/biogs/WLE0774b.htm.
} 
places. For example, Lee spent time visiting a Marae in New Zealand, spoke at leper colonies in Sri Lanka, and toured Natal and Zululand. ${ }^{14}$ Lee gave Australian women high visibility on the world stage when she spoke to a temperance audience at Exeter Hall, London, and completed voluntary work with Lady Henry Somerset at her Colony for inebriate women, Duxhurst. Lee's husband died on 17 January 1908. An admirer of Lee's work, Robert Cowie, a New Zealand farmer, wrote offering her marriage, and after much encouragement she accepted his proposal.

Lee's physical presence was larger than life, characterised by the delivery of her highly emotional, dramatic gestures and theatrics. During her final years in Pasadena, California, for example, she gained 'national wide fame when she staged a "Carry the Light" crusade into the bars and cocktail lounges of Pasadena'. ${ }^{15}$ Her weekly visits wearing placards around her neck were indicative of her public oratory. Her actions were the embodiment of a wider movement of women in the Judeo-Christian tradition who were engaged in discussions of the body in relation to heredity, eugenics, social evil (prostitution), marriage and voluntary motherhood. These women were navigating new pathways for women in the public sphere using their clothing and stance to communicate their arguments. Lee tirelessly utilised her physical body, through her demeanour and dress, in innovative and theatrical ways, and she did this consistently throughout her career as the manifestation of all that she believed in. Similarly, Elizabeth Nicholls, a contemporary of Lee's, became President of the South Australian WCTU. She too was described as a 'lucid speaker'. However, unlike Lee, she was from a privileged background and did not engage in the type of performativity that Lee did. ${ }^{16}$ Lee's unswerving placement of herself at the centre of her written and public appearances as a worker for the WCTU was central to her public persona. Lee presented herself as 'what you could be', or someone who could show 'the way'. In her own words, 'God has proved that a girl [herself] without education, money, influence, position or friends can by taking Christ's hand, and trusting her all to Him, rise to eminence'. ${ }^{17}$ By following Lee's example, a sanctified life could be obtained despite one's upbringing, whether it be in a working-class

14 Cowie, One of Australia's Daughters, 186.

15 '89 year old Temperance Crusader Dies in Sleep', Pasadena Star News, 18 April 1950, 2.

16 Marie Mune, 'Nicholls, Elizabeth Webb (1850-1943)', Australian Dictionary of Biography, National Centre of Biography, The Australian National University, adb.anu.edu.au/biography/ nicholls-elizabeth-webb-7839/text13613, 1988.

17 Cowie, One of Australia's Daughters, 153. 
environment or a family predisposed to alcoholism; she was proof that one could succeed. She therefore used herself as an example of someone who was self-educated, grew up around drinking and violence, and yet led a respected Christian lifestyle. Unlike other nineteenth-century preachers such as Catherine Booth or Jessie MacFarlane whose formative years were amongst the middle classes, Lee's childhood and early adulthood experiences were within working-class communities and her formal education was minimal. ${ }^{18}$

\section{Histories of Lee and the WCTU}

Valuable contributions have been made by scholars to restore Australian women's part in national and world suffrage history. ${ }^{19}$ Temperance was a major reform issue for most of the nineteenth century, an era that witnessed the development of successful women orators. Australian scholars have addressed the absence of temperance women in the history annals, building on Ian Tyrrell's extensive research, which employed an international lens to study women's public activism. ${ }^{20}$ Identifying temperance women more specifically in the Australian context, Lee is featured in a chapter by Patricia Grimshaw in the book Double Time: Women in Victoria, 150 Years, a collection of biographical studies that helped orientate Lee amongst prominent nineteenth- and twentiethcentury women. ${ }^{21}$ Grimshaw identified Lee's aunt as the one who instilled in Lee the importance of sexual purity in marriage, and she linked this to Lee's promotion of female personal autonomy. ${ }^{22}$ Lee further emerged as part of a new-world community of women who combined discussions of science with Christian ideals, as identified in Susan Magarey's work. ${ }^{23}$

18 Olive Anderson, 'Women Preachers in Mid-Victorian Britain: Some Reflexions on Feminism, Popular Religion and Social Change', The Historical Journal, 12, no. 3 (1969): 467-84, 470, doi. org/10.1017/s0018246x0000724x.

19 Denise George, Mary Lee: The Life and Times of a 'Turbulent Anarchist' and her Battle for Women's Rights (Adelaide: Wakefield Press, 2018), doi.org/10.1080/1031461x.2019.1662547; Myra Scott, How Australia Led the Way: Dora Meeson Coates and British Suffrage (Melbourne: Arcadia, Australian Scholarly Publishing).

20 Ian Tyrrell, Woman's World/Woman's Empire: The Woman's Christian Temperance Union in International Perspective, 1880-1930 (Chapel Hill and London: University of North Carolina Press, 1991), doi.org/10.1086/ahr/97.5.1608.

21 Patricia Grimshaw, 'The Politics of Purity', in Double Time: Women in Victoria, 150 Years, eds. Marilyn Lake and Farley Kelly (Ringwood: Penguin Books, 1995).

22 Patricia Grimshaw, Marilyn Lake, Ann McGrath, and Marian Quartly, Creating a Nation (Ringwood: McPhee Gribble Publishers, 1994), 187.

23 Susan Magarey, Passions of the First Wave Feminists (Sydney: UNSW Press, 2001), 3. 
This discourse on health, in particular women's control over reproduction, widened women's public role as experts on heredity and was a subject that featured in Lee's public debates and writings. ${ }^{24}$ Carol Mattingly, writing on temperance rhetoric, argued that 'labels such as conservative and radical inadequately described the complexity of women temperance leaders' arguments' ${ }^{25}$ Lee's public appearances in Church or public halls, evidenced vastly different delivery styles of dress and manner, from ostentatious to black Victorian dress. I suggest Lee walked a strategic line in promoting radical views to varied audiences, many hostile and even aggressive. Further, Mattingly's discussions surrounding the use of appearance to negotiate expectations and challenge and reconstruct the power hierarchy contribute to understanding the motivation and significance of Lee's many varied public appearances.

Australian women, including Lee, were at the forefront of debates surrounding women's suffrage. Clare Wright's You Daughters of Freedom tells the story of the victory of suffrage for women in Australia and therefore highlights the many public methods of protest utilised in Australia and overseas. ${ }^{26}$ In this work, Wright details a political world to which Lee was privy. There were other similar female political figures at the time who operated like Lee. For example, Wright's discussion of Vida Goldstein's public appearances alongside the likes of Alfred Deakin, Reverend Strong and the Lord Mayor illustrated how women representing various organisations were placed under scrutiny according to their dress and demeanour. Wright noted that the reports in the newspapers about Goldstein's speeches were loosely reported as 'her presence on the stage was newsworthy enough'. ${ }^{27}$ James Keating's work on Vida Goldstein identified her state, national and international loyalties. ${ }^{28}$ Lee similarly embodied this trend and declared herself 'One of Australia's Daughters', a title she was proud of during her national and international tours. Other literature that aided the analysis of Lee's public role is Yan Shu-Chuan's research on popular representation of fashionable female bodies in nineteenth-

\footnotetext{
24 Ibid.

25 Carol Mattingly, Well Tempered Women: Nineteenth Century Temperance Rhetoric (Carbondale: Southern Illinois University Press, 1998), 1; Carol Mattingly, Appropriating Dress: Women's Rhetorical Style in Nineteenth Century America (Carbondale and Edwardsville: Southern Illinois University Press, 2002). 26 Clare Wright, You Daughters of Freedom, The Australians Who Won the Vote and Inspired the World (Melbourne: Text Publishing Company, 2018), doi.org/10.1017/qre.2019.18.

27 Ibid., 36.

28 James Keating, “An Utter Absence of National Feeling”: Australian Women and the International Suffrage Movement, 1900-14', Australian Historical Studies, 47, no. 3 (2016): 462-81, 480, doi.org /10.1080/1031461x.2016.1194441.
} 
century periodicals. It acknowledges that the status of women and dress performed a major role in the social construction of identity, which assisted in decoding Lee's costumes and theatrical performances. ${ }^{29}$ Shu-Chuan argues that dress became a symbolic language, a kind of personal glossary and a species of body phrenology. Similarly, Lisa Tickner's work on the imagery of the British Suffrage Campaign 1907-14 contributed to historians viewing activists like Lee as part of the broad movement of women who utilised 'the agitation by symbol'. ${ }^{30}$ Taking from Tickner's argument, imagery that was cultivated in the public spectacle was 'not a footnote of or an illustration to the "real" political history going on elsewhere, but an integral part of the fabric of social conflict'. ${ }^{31}$

In this article, I contribute to the historical literature discussed here by focusing on the very theatrical and innovative nature of Lee's public performances, which were emblematic of public debates about social justice issues that were contemporaneous with Lee's performances. I argue that revisiting this aspect of Lee's life shows us that the WCTU provided the environment for a working-class woman to move up through the ranks and publicly communicate radical ideas behind the veil of a hyper-conservative organisation. Women in this period, rather than shrinking from attention, utilised it to convey powerful messages for social change. Historians like Olive Anderson show women preachers in Victorian Britain examined the 'drawing power' of early 'lady preachers' and the utilisation of dress to cultivate and demand a certain mood from the audience. ${ }^{32}$ Other case studies of female Christian followers such as Salvation Army worker Catherine Booth, or American Martha Neumark in the Judaism tradition, also confirm a rich history of women working the public arena using their posture, gestures or clothing to further their claims. ${ }^{33}$ Thus, historians have demonstrated the pivotal place of women

29 Shu-Chuan Yan, '(Ad)dressing Women: Fashion and Body Image in Punch, 1850s-1860s', Women's Studies, 43, no. 6 (2014): 750-73, doi.org/10.1080/00497878.2014.921510.

30 Lisa Tickner, The Spectacle of Women, Imagery of the Suffrage Campaign, 1907-14 (Chicago: University of Chicago Press, 1988), doi.org/10.1086/ahr/95.1.169.

31 Ibid., ix.

32 Olive Anderson, 'Women Preachers in Mid-Victorian Britain: Some Reflexions on Feminism, Popular Religion and Social Change', The Historical Journal, 12, no. 3 (1969): 467-84, doi. org/10.1017/s0018246x0000724x.

33 Roger J Green, 'Catharine Booth, The Salvation Army, and the Purity Crusade of 1885', Priscilla Papers, 22, no. 3 (2008): 9-18; Ellen M Umansky, 'Women in Judaism: From the Reform Movement to Contemporary Jewish Religious Feminism', in Women of Spirit: Female Leadership in the Jewish and Christian Traditions, eds. Rosemary Ruether and Eleanor McLaughlin (New York: Simon \& Schuster, 1979), doi.org/10.2307/3164818. 
and their embodied practices in such contexts. A study of Lee shows her as part of this movement, where women asserted their values in multiple contexts and adds to the above literature as a detailed examination of someone who, from working class not middle class, was similarly prominent and mobile. Lee sustained her public persona for the full duration of her career.

I begin this study by examining Lee's attendance in a coat of arms dress at the Colonial and Foreign Stall, London. She represented the newly created nation Australia in the celebration of the coronation of King George V. Then, I consider Lee's symbolic costume style during her passage on the ship Naldera to India. Furthering the study of Lee's performative dress style, I offer a discussion of her pageant presentations titled Bride of Many nations. I then turn to Lee's representation in photos and how they further enhanced her activism.

\section{Colonial and Foreign Stall}

The centrality and conspicuous public nature of Lee's appearances was exemplified by her arrival in a coat of arms dress to the Colonial and Foreign Stall, London, in 1911, which coincided with the Coronation of King George V of England at Westminster Abbey. Representations from British colonies attended, along with items that represented each colony's characteristics. 'Australian women', according to Keating, 'were enthusiastic member[s] of an International community' and Lee's presence in this event, culminating in the desire for Britain to enfranchise its women, evidenced this. ${ }^{34}$ This event took place after her marriage to her second husband Robert Cowie, her appointment as a WWCTU Missionary, and during the infancy of Australia's Federation. The wearing of the dress with Australia's coat of arms painted on its hem was significant because Lee used her body as a site to celebrate a new nation that was at the forefront of debates on contemporary social issues. At first glance, this ostentatious act appeared to contravene Evangelical values that emphasised spiritual inwardness; on the contrary, 'Evangelicalism gave women licence to move beyond home and hearth to places of diplomatic transnational forums' (London, in this case). ${ }^{35}$ Lee was reported in the Australian coat of arms 
costume in the numerous temperance and mainstream newspapers and in her own children's text, Auntie Faith's Rhymes. ${ }^{36}$ The South Australian women's temperance newspaper Our Federation wrote the following:

A public meeting in the evening was well attended, and proved of the highest interest. Mrs Stevens presided and ranged on the platform where the high officials of the union from many lands, Indian, Burmese, Australian, and Icelandic costumes were worn, adding a dash of colour that pleased the Genevese as much as the delegates themselves. Rev. M. Sauvin offered a prayer and afterwards kindly translated several speeches. Mrs Harrison Lee delivered a delightful speech. She was attired in a beautiful white satin dress, upon which was painted the Australian coat of arms and its motto 'Advance Australia' and a spray of the Australian wattle blossom crowned on her head. She excited great interest. ${ }^{37}$

Unapologetically bold at the stall, Lee signified the newly formed Commonwealth's authority and ownership; and rather than being quiet in movement and mind, she 'proved of the highest interest'. The infusion of colonial symbols provided an alternate iconography to the masculine images of colonial advancement - the bushman, shearer or pastoralist. As Chuan identified when studying earlier representations of women in magazines, the female body, adorned in this case with iconic wattle, could be used as 'a bearer of public sentiment, assumption and opinion within the context of fashion'. ${ }^{38}$ The celebrations of the new nation consisted of 'Britannia and her daughter Australia, a maiden in white', not dissimilar to what Lee was wearing on this occasion. ${ }^{39}$ The symbol of the new nation on public banners and press was a young, white, virginal Goddess and the entire spectacle of Lee's coat of arms dress was 'predicated upon an acceptance of the universality of whiteness', equated with purity, strength and morality. ${ }^{40}$ Events such as these illuminate the complex role women played in the formation of the values and ideals that the Federation was founded on.

36 Bessie Harrison Lee, Aunty Faith's Rhymes (Melbourne: JJ Howard, 1911).

37 'Advance Australia', Our Federation, 15 August 1903.

38 Yan, '(Ad)dressing Women', 753.

39 Raymond Evans, 'White Citizenship: Nationhood and Race at Federation', Memoirs of the Queensland Museum, Cultural Heritage Series 2, part 2 (2002): 182.

40 Ibid., 180. 


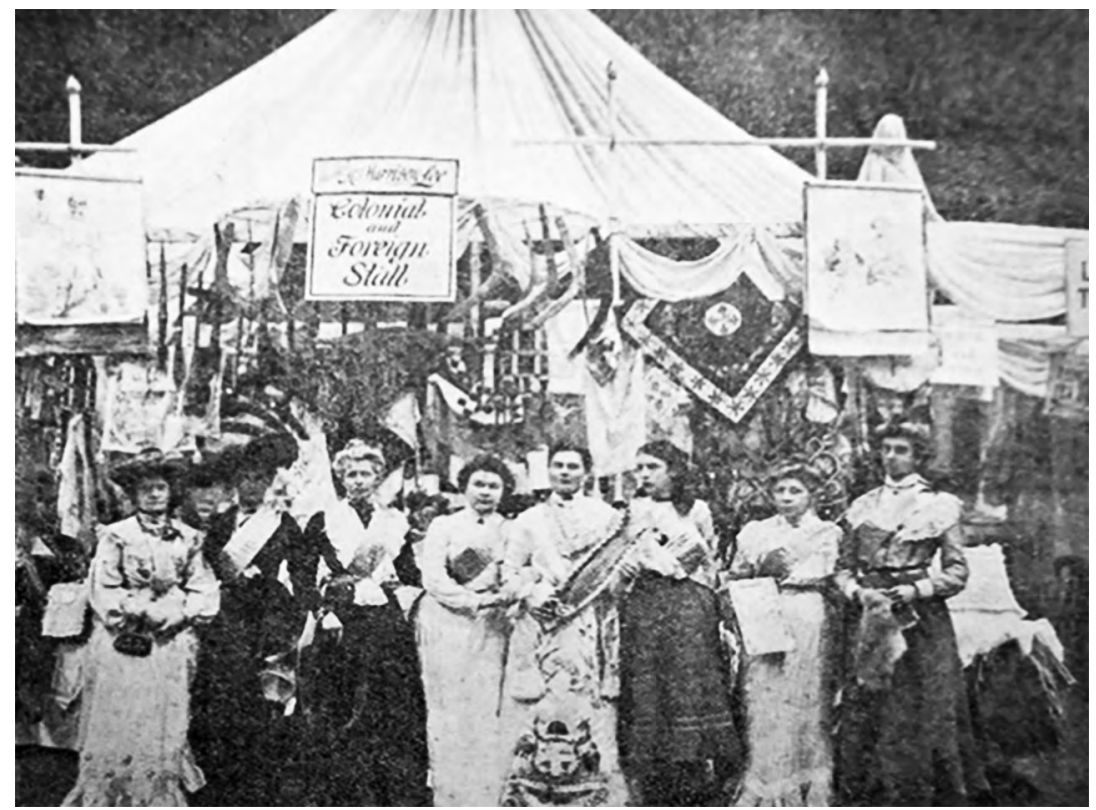

Figure 2: Auntie Faith's Bazaar Stall. Lee is fifth from left.

Source: Mrs Harrison Lee Cowie, Auntie Faith's Travels (London: Richard J James, Temperance Publishing House, 1910).

The idealisation of mother and home had been empowering for women and daughters; however, by the late nineteenth century, competing discourses of science, professional medicine and secularisation were eroding motherhood's authority. ${ }^{41}$ In centring herself, Lee and the WCTU worked against this trend and continued to elevate and affirm motherhood and articulate dissatisfaction with society's temptations. The public celebration of the newly formed nation framed within familiar metaphors of motherhood, purity and the home were also utilised in Lee's written autobiographies, where she would refer to the 'Goddess of Temperance versus Giant Alcohol'.42 These images encouraged questions about what it meant to be a woman in the early formative years of the nation. White women were elevated by their responsibilities to populate the new nation, where they 'had a central part to play in economic growth-

41 Patricia Grimshaw, Jim Hammerton and Eileen J Yeo, 'Introduction', Women's History Review, 8, no. 2 (1999): 193-9.

42 Bessie Harrison Lee Cowie, One of God's Lamplighters: Incidents in My Life-work. Being a Continuation of 'One of Australia's Daughters' (London: Ideal Publishing Union, 1902); Sue Morgan, 'Faith, Sex and Purity: The Religio-feminist Theory of Ellice Hopkins', Women's History Review, 9, no. 1 (2000): 18, doi.org/10.1080/09612020000200235. 
women in their capacity as mothers. ${ }^{43}$ White babies were a national asset, motherhood a national service. ${ }^{44}$ In early Federated Australia, as a result of these directives, white citizens received what were probably the most advanced welfare reforms in the world, the maternity allowance. ${ }^{45}$ While white married mothers received this bonus to boost the 'flagging birth rate against the threat of Asian invasion', these pronounced political rights, however, disadvantaged Aboriginal inhabitants. Evans argued: 'nowhere else on earth were Indigenous people so totally denied human rights by their conquerors. ${ }^{46}$

Lee's projection of herself with the coat of arms dress at the Colonial and Foreign Stall provided her room to show herself acting in different guises. She could cross traditional boundaries of female behaviour as modest and self-effacing to the forefront of flamboyancy.

\section{Naldera}

On board the passenger ship Naldera on voyage to India in 1924, Lee walked to a fancy dress ball exhibiting a similarly ostentatious style to the coat of arms dress, with large metaphorical pictures pinned to her skirt, chest and back communicating her temperance ideas. ${ }^{47}$ The purpose of Lee's journey was to visit 16 Christian missions in India and Ceylon, including leprosy colonies. ${ }^{48}$ When steam trains were first introduced in the early 1800 s, it was difficult for proper society to envision how a woman could travel in public and still adhere to the requirements of domesticity, as trains were projected as overwhelmingly masculine, brawny, dynamic and dominating. ${ }^{49}$ Lee presented herself as someone who was not reluctant to leave a domesticated space or her cabin

43 Grimshaw, Lake, McGrath and Quartly, Creating a Nation, 206.

44 Renata Howe and Shirlee Swain, 'Fertile Grounds for Divorce, Sexuality and Reproductive Imperatives', in Gender Relations in Australia, Domination and Negotiation, eds. Kay Saunders and Raymond Evans (Sydney: Harcourt Brace Jovanovich, 1992), 168, doi. org/10.1177/144078339603200308.

45 Evans, 'White Citizenship', 183.

46 Ibid., 184.

47 'Mrs Lee Cowie as "Prohibition”', White Ribbon, 18 June 1925, 7.

48 Cowie, One of Australia's Daughters.

49 Frances Steel, Oceania Under Steam: Sea Transport and the Cultures of Colonialism, c1870-1914 (Manchester: Manchester University Press, 2011); Frances Steel, 'Women, Men and the Southern Octopus: Shipboard Gender Relationships in the Age of Steam, 1870s-1910s', International Journal of Maritime History, 20, no. 2 (2008): 287, doi.org/10.1177/084387140802000214. 
(the ship equivalent), but relished being a spectacle, dominating the floor. The image of Lee as an eager participant in fancy dress represents a confident, strong woman who sat in tension with other conventional accounts of women as pious, pure, submissive and living within the domestic sphere. This is the description of Lee's 1924 voyage to India that was published in New Zealand's White Ribbon Journal. By then, she referred to herself as Mrs Cowie, or Mrs Bessie Lee Cowie, taking Robert Cowie's surname:

Mrs Cowie was dressed up as 'Prohibition', with big pictures on cloth, both on chest and back, and tied round her as a skirt; and she carried a banner which showed the sun in one corner, smiling down on the earth. The sun was prohibition, and on the earth was sitting a big frog called 'Booze', which said, "Soon there will not be a damp spot on earth." The pictures on her person were equally effective, representing a group of children to be saved, and a sieve showing all the different drinks that he manufactured from oats, barley, maize, etc., also a 'world' weeping, the result of drink, and a world smiling and happy when Prohibition comes. There were various mottoes, eg. "Sign the pledge and fight for abolition," etc. It was awfully good and she was a rare sport. She was very prominent, and it was a rare opportunity for Temperance propaganda. ${ }^{50}$

This description identifies Lee, nineteenth-century evangelical, temperance and suffrage activist, as a woman who maintained a consistently powerful public presence in both her oratory public performance and written publications. The melodramatic narrative of the story outlined on her dress had reached its conclusion, as good had overcome evil and moral order had been restored. Lee tapped into Victorian performance culture, the success of which depended not only on its fantastic spectacle, but also on the accessibility and popularity of its topical commentary. ${ }^{51}$ Women travellers were by no means celebrated and were often the focus of critical scrutiny; yet here Lee's dress demanded of her audience shock and thrill, through the comedic and the serious. ${ }^{52}$ Theatrical events orchestrated and acted by Lee saw their embryonic stages in performances like this, which showed the

50 'Mrs Lee Cowie as "Prohibition"', 7.

51 Peter Yeandle, Citizenship, Nation, Empire: The Politics of History in England, 1870-1930 (Manchester: Manchester United Press, 2015), 127, doi.org/10.1111/1468-229x.12179.

52 Indira Ghose, Women Travellers in Colonial India, The Power of the Female Gaze (Delhi: Oxford University Press, 1998), 8. 
importance of image creation to communicate and capture an imagined space of connectivity between WCTU women and the wider public. Lee's ostentatious performances continued throughout her career, drawing her more intimately to her audiences as opposed to ostracising her. On the contrary, up to a generation before Lee, many women who held careers in acting or other performance-related activities were not accepted as part of proper society. To illustrate this, Celeste Venard married Count Lionel de Chabrillan, the first French Consular Agent in the Colony of Victoria, much to his family's aversion. Celeste's highly scandalous memoirs included her participation in polka dancing, acting, riding horseback in a circus and her life as a Parisian courtesan. She was labelled the 'harlot spouse' by the early settler community. ${ }^{53}$ Similarly, Lola Montez, entrepreneurial actress and dancer, was reportedly conducting scandalous dance performances for the gold-digging community of Ballarat. ${ }^{54}$ The success of Lee's staged performances indicated cultural forces that were broadening the landscape for women's public activity. It also shows that Lee was confident to take risks and utilise forums such as a fancy-dress ball on the Naldera not previously available for women.

\section{Brides of Many Nations}

The success of Lee's staged performances indicated cultural forces that were not only broadening the landscape for women's public activity, but also using it as a vehicle to promote WCTU ideas on marriage and purity. The 'Brides of Nations Pageant', written and choreographed by Lee in Adelaide in 1908, intended to symbolise and unite women from different nations through the celebration of a wedding, an event that connected and engaged them with other women of the world.

53 Patricia Clancy and Jeanne Allen trans., The French Consul's Wife, Memoirs of Celeste de Chabrillan in Gold Rush Australia (Melbourne: Melbourne University Press, 1998).

54 Katina Banyai, ed., Bling, 19th Century Goldfields Jeweller (Ballarat: Museum of Modern Democracy, 2016), 53. 


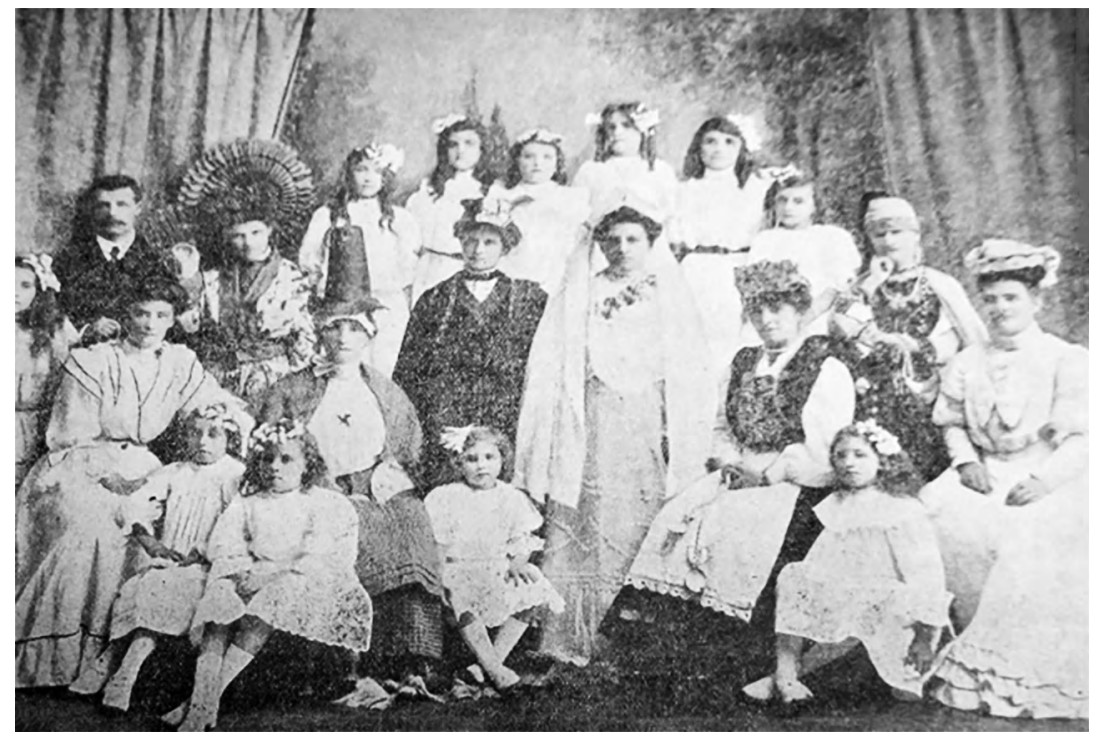

Figure 3: Brides of Many Nations.

Source: The White Ribbon, New Zealand, 15 October 1908.

This was not a linear narrative but a performance infused with familiar religious and cultural rituals that women of disparate British and European nations would have identified with. Women were universally the focal point of the marriage service, and so it was only natural that Lee used this in her performance to celebrate the Christian marriage and the success of prohibition in some countries, which elevated a bride's happiness. The Evening Post reported that Lee was:

Very theatrical in her addresses, she took her audience for a trip round the world, touching on many incidents and scenes she had witnessed during her travels. She referred at some length to what she had seen and heard of the Prohibition states in America. ${ }^{55}$

The glamour and lure of adventure unfolded majestically in front of her audience, her style derived from the pantomime traditions, the burlesque and the extravaganza. French, German, Scandinavian and Celtic folk stories were adapted for an English audience, and although told in a humorous tone, they often reverted to the serious message and complex

55 'Mrs Harrison Lee’s Mission', Colonist, vol. L, no. 1229 (1908): 2; 'No Licence', Evening Post, xxvi no. 22, 25 July 1908, 9. 
WCTU ideology of a Christian Temperance lifestyle. ${ }^{56}$ For example, Lee spoke and wrote about comical traditions behind Scottish courting rituals and then used the light-hearted tone of her talk to emphasise the Scottish 'war on whiskey'. ${ }^{57}$ Lee highlighted that 'the happiness of a bride was wrecked by "the evils of drink" and noted the Norwegian and Swedish brides were the happiest as their countries had many drink licences. ${ }^{58}$ What appeared as pantomime entertainment, however, subliminally offered a critique of indigenous races by their notable absence. When Indigenous Australians were included in the narrative it was done in a condemnatory, repetitive style, as exemplified by this quote in the Bendigo Advertiser:

Mrs Lee then gave an amazing description of the marriage customs of the Australian Aborigines. Usually when an Australian native wanted a bride he waited behind a gum tree and when a lubra appeared he simply struck her on the head with a club, and carried off his bride. That was the beginning and the end of the aborigines [sic] marriage festival..$^{59}$

As Philippa Levine noted, this is just one example of how writers borrowed freely from one another, superimposing imagery from enslaved and colonised women from diverse scenarios of racial difference. ${ }^{60}$ Through the reiteration of the above types of tropes, racial differences became entrenched in formal and informal conversation. For example, in her work on the early First Fleet accounts of bridal capture of Aboriginal women by their menfolk, Inga Clendinnen highlighted that 'too many reports were simply recirculation derived from a mere handful of speculative and unsubstantiated textual contrivances' ${ }^{61}$ Despite Lee's opportunities to access changing ideas, this was often not evident in her attitudes to race. The Bride of Many Nations cultivated a pictorial vocabulary of various ways of rejoicing in the Christian marriage, invited viewers to validate this, endorsed the reduction in liquor licences, and reminded the audience of the precarious position of the white race. Although Lee

56 Jennifer Schacker, 'Unruly Tales: Ideology, Anxiety and the Regulation of Genre', Journal of American Folklore, 120, no. 478 (2007): 381-400, doi.org/10.1353/jaf.2007.0066.

57 Bessie Harrison Lee Cowie, 'Brides of Many Nations', Goulbourn Evening Penny Post, 12 August $1913,2$.

58 Ibid.

59 'Temperance Crusade: Lecture by Mrs Harrison Lee "Brides of Many Nations", Bendigo Advertiser, 6 May 1908.

60 Philippa Levine, 'States of Undress: Nakedness and the Colonial Imagination', Victorian Studies, 50, no. 2 (2008): 189-219, doi.org/10.2979/vic.2008.50.2.189.

61 Liz Conor, Skin Deep, Settler Impressions of Aboriginal Women (Crawley: University of Western Australia Publishing, 2016), 93; Inga Clendinnen, Dancing with Strangers (Melbourne: Text Publishers, 2003), 159-60. 
emphasised the transnational experience of being a bride, she highlighted that 'the English wedding garb was the most charming of all', thereby reinforcing established racial thinking at the time. ${ }^{62}$ The opinion column of New Zealand's Ashburton Guardian reported:

Mrs Harrison Lee will address the Electors of Ashburton in the Oddfellows' Hall tonight, Thursday November 13 Mrs Harrison Lee's farewell meeting subject, "Beautiful Britain its blessings and its blight", as seen by a Colonial. The subject tonight will be "patriotic songs and beautiful views" illustrated on the canvas. ${ }^{63}$

In this public environment Lee was represented as an expert in her field, forging comparisons between celebration and criticism of British culture.

\section{New Zealand}

A photograph of Lee taken in 1899, during the first of many visits to New Zealand, shows her speaking authoritatively to a crowd on the evils of drink from the top balcony at Scotts Junction Hotel, Rangiora. ${ }^{64}$ It provides many clues to Lee's ability to craft a confident female space on this public stage. Her confidence is emphasised by her position overlooking and talking down to a male audience below. Her outer public representation in impeccable Victorian dress was socially coded to signify her exemplary moral character and emanated nothing but self-assurance. Lee stands where domestic staff traditionally stood to have their photographs taken, while their employers stood at the entrance below. These conventions conveyed 'contemporary knowledge of sexual difference and a rather obvious representation of women as domestic servants'. ${ }^{65}$ The image conformed to the separation of private and public spaces, of the spatial arrangements of pubs, and of sexual differentiation. Here the image subverts the traditional image of a male proselytising from a pulpit or political podium, his power emanating from the top balcony to the audience below. The framework encapsulates Lee's authorial role and how an Australian woman, energised by her relatively recent travels to Britain and Australia, was naturally confident to bestow her learned ideas to a hostile audience. The photograph captures the physical

62 Cowie, 'Brides of Many Nations', 2.

63 'No Licence Campaign', Ashburton Guardian, 13 November 1902, 3.

64 Alexander Turnbull Library F19635 1/2.

65 Diane Kirkby, Barmaids: A History of Women's Work in Pubs (Melbourne: Cambridge University Press, 1997), 59, doi.org/10.1086/shad18010100. 
manifestation of the rhetoric for which Lee was famous. At all the WCTU and WWCTU events, meetings and local option campaigns, when Lee delivered temperance speeches she placed herself at the centre of the physical stage and consistently privileged her narrative of life as a young vulnerable child in a volatile alcoholic environment as the prime motivator for her work. Lee's recollection of events, the feelings of loneliness, confusion, isolation, abandonment, dislocation from family and community qualified her to speak with experience. Lee's subsequent religious conversion, her intense inner spiritual life, provided the audience with keys to her identity and motivation. More importantly, it reaffirmed that heredity was not an excuse for 'wrong doing', as she used herself as an example: 'God has proved that a girl without education, money, influence, position, or friends can, by taking God's hand, and trusting her all to Him, rise to any eminence. ${ }^{66}$ Lee was exemplary in presenting herself as someone subjected to an alcoholic environment as a child, but who through faith and lifestyle rejected 'King Alcohol'.

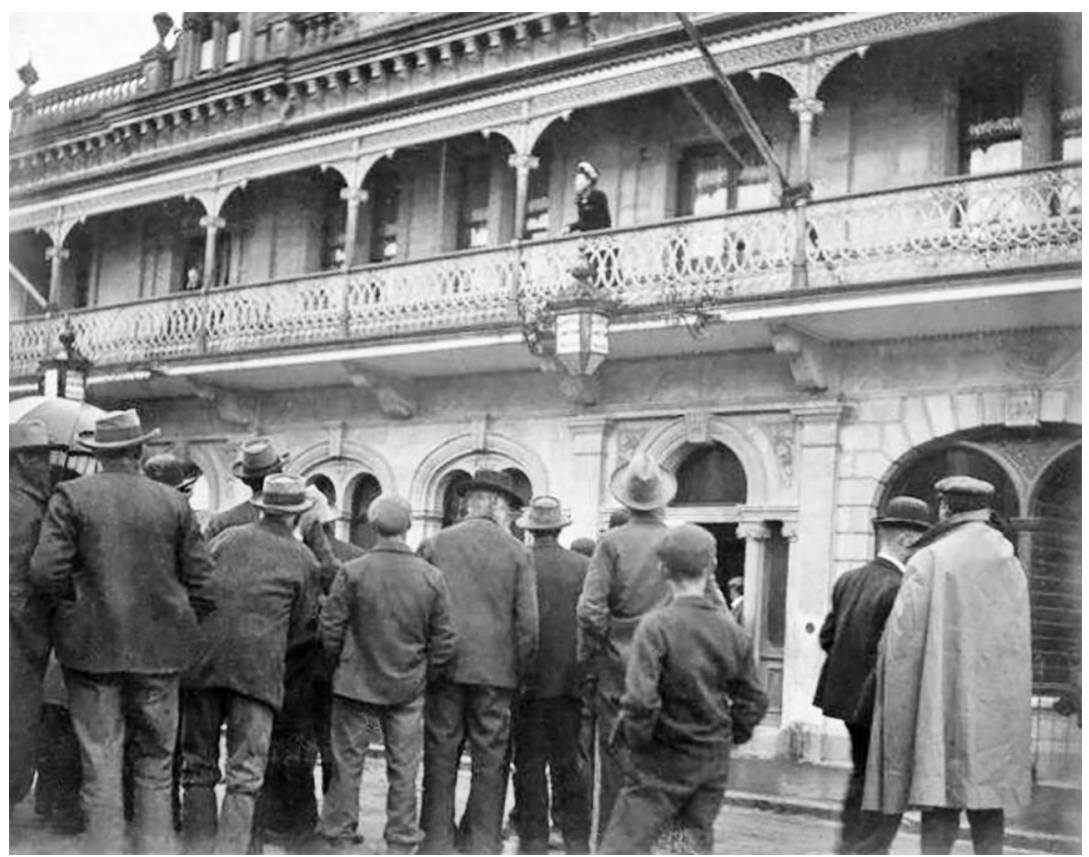

Figure 4: Lee on the top balcony of Scotts Junction Hotel, Rangiora.

Source: Mrs Harrison Lee, 'Scotts Junction Rangiora New Zealand', Alexander Turnbull Library, F196351/2.

66 Cowie, One of Australia's Daughters. 


\section{Holy Spirit Imagery}

The photographs that form an imperative part of Lee's publications utilise her image as an exemplary figure whose outward appearance signified, according to holiness teaching, the 'ever increasing likeness to Christ in love through the gracious indwelling presence of the Holy Spirit'. ${ }^{67}$ Within the framework of evangelicalism, the holiness movement identified that salvation transforms believers' inner lives in a way that actually helps them to live without committing sin. While different holiness churches have differing explanations on how this happens, they generally agree that the living Holy Spirit in believers helps them to obey God. ${ }^{68}$

The glorification of image was a trend evidenced in the WCTU, where portraits of Frances Willard, the leader of the American WCTU, were placed in a central position at their weekly meetings or official events. The image would replicate a religious environment, where flowers would adorn the border of Willard's portrait honouring her importance. Lee also adapted and refined this trend. She distributed photos of herself with captions on them to inspire temperance, reminiscent of the distribution of holy cards. In Yarragon, Victoria, Lee described a 'poor fellow' who requested her photograph. She recorded the exchange as follows:

A poor fellow just recovering from a drinking bout, came to the home at which I was stopping to get a pledge card, and to ask most humbly for the gift of inspiration to do better. I had in my work such a tremendous demand for photos, that in self-defence I had to put a price on them, and they were sold for the benefit of special branches of my far reaching enterprises. ${ }^{69}$

Whilst fashion potentially 'operated as a psychically powerful sign system for seducing women into becoming narcissistic, passive objects to be looked at by men', Lee transformed her image into a public display that sought to motivate the people she encountered. ${ }^{70}$

67 Charles Yrigoyen Jr and Susan E Warick, Historical Dictionary of Methodism (Lanham: Scarecrow Press, Inc., 2013), 186.

68 Kenneth J Collins, ed., A Wesley Bibliography, 5th ed. (Nashville, TN: First Fruits Press, 2016).

69 Cowie, One of God's Lamplighters, 24.

70 Yan, '(Ad)dressing Women', 762. 
Photographs were central to Lee's non-fiction publications Marriage and Heredity and Marriage, Heredity and the Social Evil. ${ }^{71}$ The studio photograph taken by Yeoman and Company (Melbourne) epitomises Lee as a site of empowerment, 'the bearer of Holyness'. ${ }^{72}$ It displays Lee behind a desk in a formal Victorian dress. The outfit is a typical 'tailor-made suit', the skirt slim in the front and still very full behind. The sleeves are long and her bodice short at the hip. Lee stands tall and wears a fur tippet, fashionable for middle-class women at the time-practical, comfortable and respectable. ${ }^{73}$

The encapsulation of the gender mores of Victorian society within Lee's photographic images operated by giving Lee latitude-giving her room to move without radically changing the normative rules governing gender difference. Accompanying her photograph are two biblical quotations: one from the Old Testament's Book of Isaiah (62:6), 'I have set watchmen upon thy walls, who shall never hold their peace day nor night. Ye that make mention of the Lord keep not silent'; and another from the New Testament's Gospel of Matthew, verse 8, 'Blessed are the pure in heart, for they shall see God'. These references are highly significant in elevating Lee's status as one of these 'watchmen' who 'shall never hold their peace'; hardly a command to be complacent, but to be a woman with a utopian vision that encompassed a female corrective that was urgently needed to establish an authentic Christian faith. Lee's photograph speaks of someone who was singled out to carry out God's work, a radical directive. The photos, poetry and biblical quotations position readers to observe Lee as someone who was endorsed to speak publicly about social concerns and provide direction forward. She wrote:

I am deeply impressed with the immensity of the task I have undertaken. Nothing short, indeed of attempting a revolution of all our social and domestic relationships; and as the work is great, so do I expect the reward to be great. ${ }^{74}$

Lee's confident style and inherent ideals displayed in the studio photographs were confidently reiterated in various mediums.

71 Bessie Harrison Lee Cowie, Marriage and Heredity (Melbourne: JJ Howard, 1893); Lee, Marriage, Heredity and the Social Evil.

72 'Colonial Evangelist's Report, 1889', WCTU Convention.

73 Yvette Mahe, 'Furs in Fashion in the Early Twentieth Century' (2013), www.fashionintime.org/ furs-fashion-early-twentieth-century/ (site discontinued).

74 Cowie, Marriage and Heredity. 


\section{Women and Travel: Lee's Journeys}

What was also extraordinary is the reporting of Lee's 11-month travels by The Woman's Signal, a weekly British temperance and women's magazine. Even in preparation of Lee's arrival, The Woman's Signal promoted her popularity with the following introduction: 'Among our colonial visitors this year, will be Mrs Bessie Harrison one of the best known and most successful of women Temperance advocates at the Antipodes. ${ }^{75}$ The editor Florence Fenwick Miller confirmed Bessie's popularity with:

Mrs Harrison Bessie our welcome Australian visitor has quickly received the best testimony possible to the pleasure that is given British women to receive a sister from out distant British Colonies she has already booked every date possible for addressing meetings during her stay in the Motherland. ${ }^{76}$

Over the 11-month travel period, Lee's photograph was published several times on the front page of The Woman's Signal and details of her interactions with fellow temperance workers documented. An example of one such article was a full-page commentary on Lee titled 'Mrs Bessie Harrison, A character sketch'. This article was accompanied by a large profile photograph of her centre page that endorsed her as a leading temperance figure. ${ }^{77}$ Whilst Miller thought that Lee could learn from British women's 'methods of welfare ... to demolish this giant foe', the editor was also open to what Lee 'could teach them'. ${ }^{78}$

75 Woman's Signal, 16 July 1896. The Woman's Signal was a weekly British feminist magazine published by Marshall \& Son, London, from 4 January 1894 to 23 March 1899. It was edited by Lady Henry Somerset, Annie Holdsworth and Florence Fenwick-Miller. Although primarily a temperance paper, it dealt with several feminist issues including fair wages. It began life as The Women's Penny Paper (27 October 1888 - 27 December 1890), edited by Helena B Temple (Henrietta Müller), later becoming The Woman's Herald (3 January 1891 - 28 December 1893). In 1892, Mrs Frank Morrison became editor, followed by Christina Bremner, then by Lady Henry Somerset in 1893. It was bought out by Lady Henry and renamed The Woman's Signal. Florence Fenwick-Miller bought the paper in 1895 and was the editor and sole proprietor until its demise in 1899 .

76 F Miller, 'Mrs Harrison Bessie, Our Welcomed Australian Visitor', Woman's Signal, 10 September 1896.

77 Woman's Signal, 30 August 1896, front page.

78 Miller, 'Character Sketch', Woman's Signal, 20 August 1896, front page. 
Twe Wounto Broxich, Acocor 20, 1800.

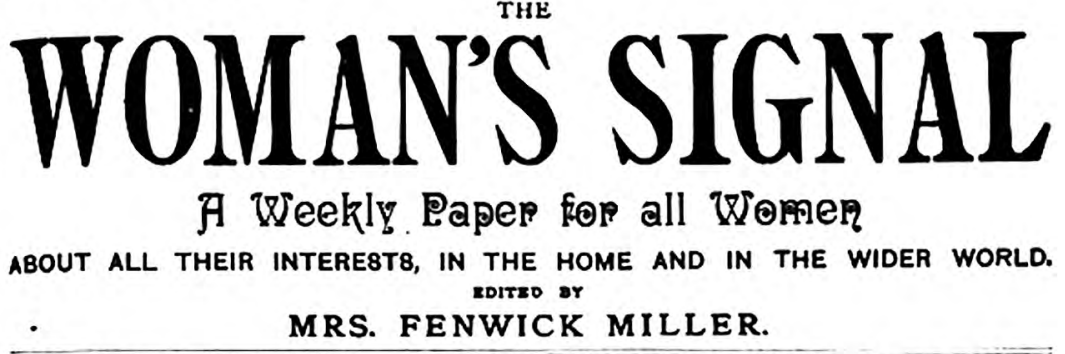

\begin{tabular}{|c|c|c|}
\hline Vor. VI., No. 138. & AUGUST 20, 1896. & On Ponny Woakly. \\
\hline
\end{tabular}

\section{Ebaracter Sketcb.}

MRS. HARRISON LEE.

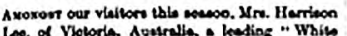

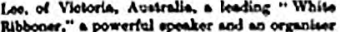

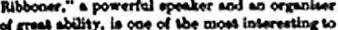
of ereas abasty. is coe of

Mm. Barrivos tee is known throaghost the

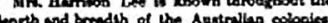
und by ber eotbuniastlo and ancereing leboars hes eamed for bereell the tisle of " Vistoris's Tecoperan os Gueve."

Tecoperan on thes.

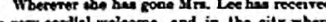
- rory cordlat webocke, and in lbe city were

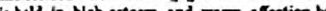

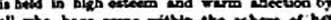
Introesce.

infracose.

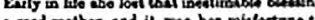
$\rightarrow$ cood molber, acd it wis her mialortase wo o lofl bo whe cart of an wank. Who thoagh good and hind reoggh ordinarily. Jet wae the herror

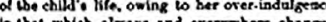
In thas wbich always and every bere change hamen boinge inss inhoman monskers-atroo

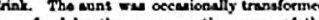
w - tend by the pecromentio power of the

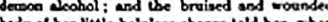
body ol bee till lo heipless charge lad ber, when withely relarsed, ol tbe depuld of enelly of

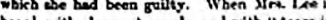
beard. with eloquent words. and with " heara in ber voike, pleseding for the listle cones whom tros are a desly martyriom becusen of tise the that we herielt bas

IIspplly, thin ebequered ebaplee of ber life

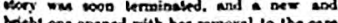
a chelser opened with ber rempinal bo the care

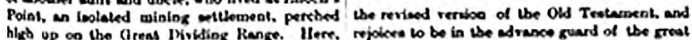

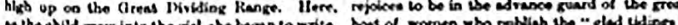

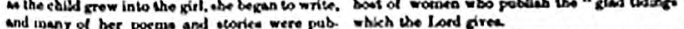
and inany of ber poecha and oconka were pus.

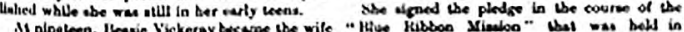

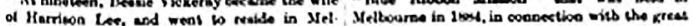
bourne. By degreses be was led into public erhibition ubere as that date. Wber laser. the

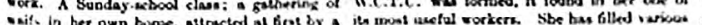
bets in ber own buaxe. attrached al hat zy a in ovile of pudding: a shibirea 3 metrike: the vis. the vepu wbich led eventually b ibe pulpit and

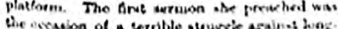
in most aueful rorkers. Sbe ban flled various.

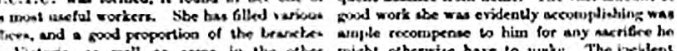

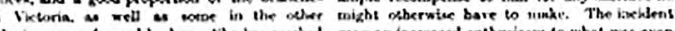

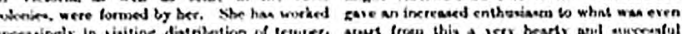

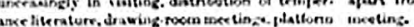

Figure 5: Lee featured on the front page of The Woman's Signal, A Weekly Paper for All Women About All Their Interests, in the Home and in the Wider World.

Source: The Woman's Signal, 20 August 1896. 
Not only was Lee traversing continents, but she was expanding her vision beyond the local and national boundaries of Australia and sharing aims for the betterment of humanity, while establishing her identity as a poised and dignified figure. This British publication described Bessie's achievements on her 11-month travels:

Wherever she has gone Mrs Bessie Harrison Lee has received a very cordial welcome, and in the city where she resided when not engaged in mission work, is held in high esteem and warm affection by all who have come within the sphere of her influence. ${ }^{79}$

Miller constructed Lee as exemplary and asked readers, 'Is Mrs Lee a New Woman? She is if the new woman is meant one who has a fuller development of the noble and lovable attributes of the old. ${ }^{\prime 80}$ This term was popularised at the time by Irish writer Sarah Grant, who promoted the image of a 'New Woman' in mind and action. Miller's choice of words encapsulated Lee as being independent, not just simply in her attitudes and values but in her engagement with a broader, more active world.

The inclusion of the following was also indicative of the characteristics Miller wanted to emphasise to a British woman's audience-a woman and marital arrangement they could emulate. Miller reported:

At a farewell meeting in Ballarat the most interesting features of the gathered was the maiden address of Mr Harrison Lee who though unaccustomed to public speaking in a few earnest words stated that his wife's work and labours had his thorough approval and he was only too glad to encourage her in her missions. Even though they involved frequent absence from home. The vast amount of good work she was evidently accomplishing was ample recompense to him for any sacrifice he might otherwise have to make. The incident gave an increased enthusiasm to what was even apart from this a very hearty and successful meeting. ${ }^{81}$

Miller used Harrison Lee's public support for his wife's travel and public profile as an exemplary model for her readers to emulate. Harrison Lee's endorsement of his wife's frequent absences from home is another reason why studying the life of Bessie is so enlightening on a number of levels. Her marital relationship, when juxtaposed with dominating

81 Miller, 'Character Sketch', Woman's Signal, 20 August 1896, front page. 
themes of masculinity promoted at the time in Australian journals such as The Bulletin highlights the varied social relations evident during this time. The magazine article invites us to look and contest the promotion of a type of masculinity that upheld male independence and considered domesticity abhorrent with the type of relationship Bessie and Harrison lived out both privately and publicly.

Other women equally placed themselves at the centre in the delivery of public addresses or public reports. For example, Victoria’s Vida Goldstein was noted for her wit and eloquence, and her ability to deal with hecklers. What is distinctive about Lee, however, is the longevity of her prolific writing and public speaking career and its particular ostentatious style. Many who were part of this generation of women who spoke in public became reclusive in the concluding years of their careers, or altered their method of attack. Vida Goldstein, for example, in her final years lived quietly with her sisters and pursued her role as a Christian Scientist practitioner.

Lee's enduring image personified the mental and physical stamina that sustained her career right up to her final years in Pasadena, California. While other women slowed down in their public duties, Lee failed to become despondent. Instead, she continued picketing bars by wearing placards, was featured on the cover of Life Magazine, and reported in numerous mainstream newspapers. In short, she was ambitious right up until her death in $1949 .{ }^{82}$ Her protests here were not dissimilar to her outlandish performance on the ship Naldera, or working the public speaking circuit in New Zealand. Lee gained nationwide fame in 1947 when she staged a 'Carry the Light' crusade into the bars and cocktail lounges of Pasadena, demanding the city enforce brighter lighting. After marching at the head of a band of 30 or 40 members of the WCTU, she succeeded in forcing the Pasadena Board of City Directors to pass a city ordinance requiring brighter illumination and improving the visibility of bars from the street. Her weekly invasions of the bars made national news and Life Magazine devoted several pages of pictures to her crusade in which she attempted to bring spiritual as well as physical light to the dark corners of Pasadena's bars.

82 'Cocktail Bars Raided by Bible Reading Women Who Meet Only Courtesy', Los Angeles Times, 26 April 1947, 1. 


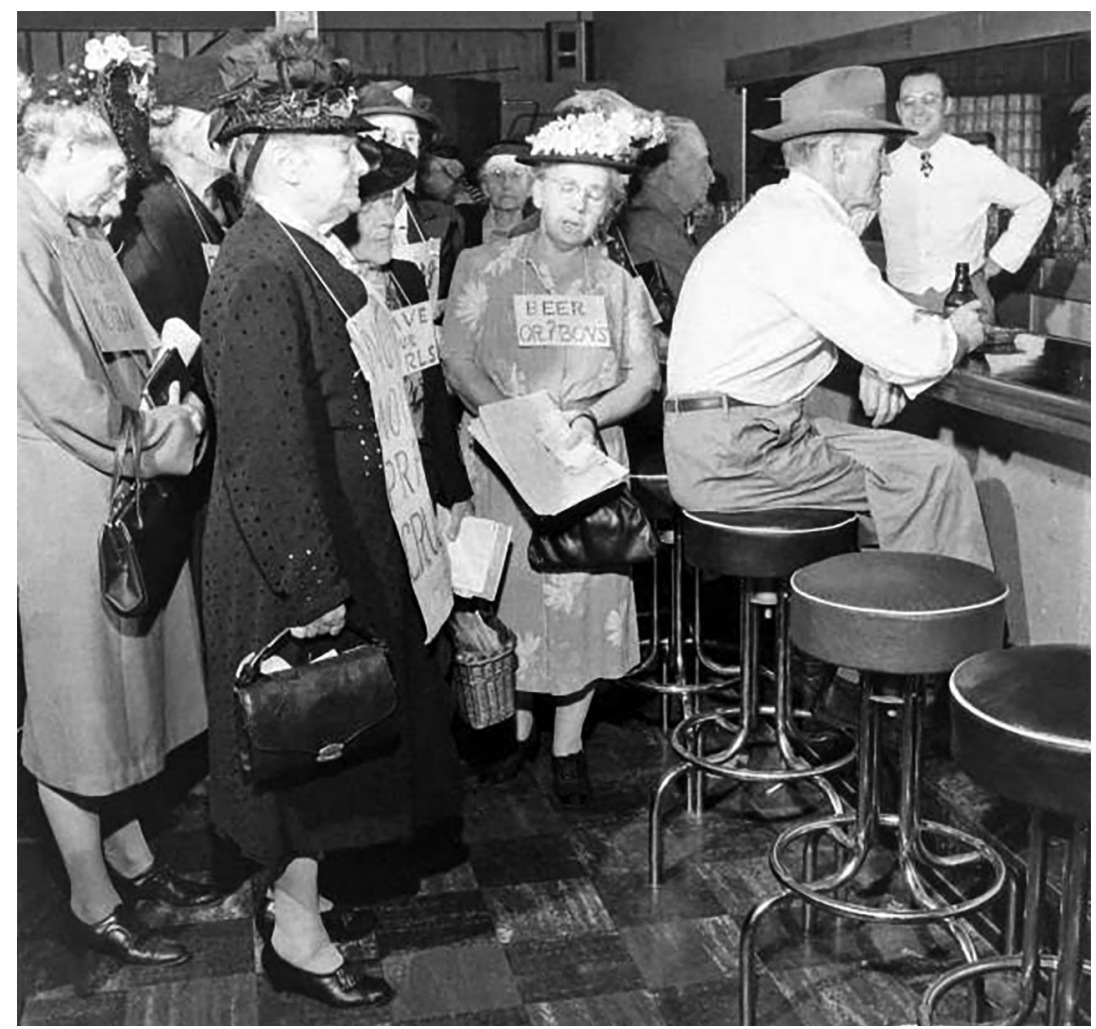

Figure 6: Lee protesting in Pasadena, California.

Source: Life Magazine, 19 May 1947.

\section{Conclusion}

Lee placed herself in the centre of public attention where she followed a long evangelical tradition of responding to introspective thought that manifested into action. Evangelicalism valued internal spirituality and the conversion experience, which involved an intense feeling of sins forgiven. From this belief, Lee wrote: 'The world has a right to all we possess, the right to the best that is in us.' The above evangelical ideas were embraced and Lee constructed her public appearances and autobiographies to walk a fine line between projecting herself as having a modest ego, while also promoting her sense of being sanctified. Despite her disadvantaged beginnings, her life was characterised by sustained public protest in the media and public oratory where she used her body to cultivate an atmosphere of Christian devotion and an aversion to alcohol. 



\title{
Body and Language: Enlivening Exhibitions of Colonial Women in Australian Museums
}

Toni Church

University of Notre Dame Australia

\begin{abstract}
The representation of women in galleries informs perceptions of women in society. Fieldwork conducted in Australian museums since 2017 has highlighted the discord between understandings of the historical role and autonomy of Australian women and the accurate embodiment of their stories in exhibition spaces. Museum exhibitions are imbued with qualitative cultural information and meaning led by curatorial intent, but also inflected with visitormade meaning. Subtle nuances of language and physicality in curatorial and exhibition design communicate messages, overt or subliminal, to audiences who carry pre-conceived cultural understandings about the world around them. This article addresses how curatorial intent and visitor interpretation produces understandings of Australian womanhood within museum exhibitions, and ways in which the methodology of displays can be adjusted to more accurately portray these women's autonomous voices and experiences.
\end{abstract}

'In this country, there are more statues of animals than there are of real Australian women', wrote Tracey Spicer in an editorial in The Sydney Morning Herald in September 2017. ${ }^{1}$ Spicer targeted the physical representation, including language, used to commemorate real (non-fictional, non-royal) women, who have been publicly cast as statues across Australia, and around the Western world. ${ }^{2}$ She further reflected that women are severely underrepresented, in their own right, in public memorialisation in Australia's

1 Tracey Spicer, 'Why Aren't More Women Immortalised in Stone?', Sydney Morning Herald, 29 September 2017, www.smh.com.au/lifestyle/tracey-spicer-why-arent-more-women-immortalisedin-stone-20170928-gyqm59.html.

2 Ibid. 
built landscape. She concluded that this 'marble ceiling', a phrase borrowed from an American study, sends a message that women's contribution to public life is not worthy of recognition. ${ }^{3}$

She built upon the work of Nilanjana Roy, whose editorial in the Financial Times a few months earlier called out the persistent 'statue gap' of the modern era-arguing that this visual silence:

goes beyond political correctness: what children and teenagers see of the world shapes their view of it, their sense of the place they should occupy. It's not enough to have women's images reflected only in billboards and advertisements - they must also be part of historical memory. ${ }^{4}$

The meaningful recognition of women's contributions to history in Australia has arguably not yet been fully (and accurately) translated into public memorialisation and, as an extension, in cultural heritage practice. A lack of accurate representation of women's contribution to Australian history informs broader public assumptions that this contribution is insignificant.

Reframing how women are represented within Australian cultural heritage by enlivening their experiences through language and physicality, can contribute to them being more accurately remembered in Australian historical memory. While cultural heritage encapsulates statues, memorials, built heritage, oral history, galleries and more, this paper will use industry practice in leading Australian museums and galleries and the methods they employ as examples of the representation of stories and experiences of women in public spaces. Once an exhibition subject is chosen, the methods employed by these museums to personify female characters fall into two main categories: language and physicality.

While the poetics of exhibition design produce meaning through the interrelation of elements within the display, it is the choices of language that most clearly articulate curatorial perspective and intent, and influence how a visitor perceives these chosen characters and stories on display. ${ }^{5}$ Museums also wield the physical in their storytelling. More specifically, the physical representation of bodies within galleries project subconscious cultural signposts to which visitors respond. It has long been established

3 Ibid.

4 Nilanjana Roy, 'Why Aren't There More Statues of Women?', Financial Times, 7 June 2017, www.ft.com/content/2f9137c6-49ff-11e7-a3f4-c742b9791d43.

5 Rhiannon Mason, 'Cultural Theory and Museum Studies', in A Companion to Museum Studies, ed. Sharon Macdonald (Chicester: Wiley, 2008), 20. 
that museum objects provide visitors with a 'touchstone for their life experiences', but even more subtle design features influence a visitor's perception of the subject and can reinforce societal values. ${ }^{6}$

This paper will address the embodiment of women's stories through mannequin design, pose and costume to understand the power that museums have in altering traditional forms of female characterisation. Such alterations can lift the character of real-life women out of stock standard mannequin bodies, and place their words, their self-reflection and their autonomy into the exhibition space. More specifically, it will look at methods of representing colonial Australian women in gallery spaces. Historically, this group were tied to their male counterpartsboth in life and appearance in historical memory-but following trends in academic feminist historiography that more fully embraced women's autonomy on the frontier, museums also brought Australian colonial women into their galleries.

In 2017, when Spicer penned her article on the public memorialisation of women in Australia, I was undertaking fieldwork in support of the beginnings of a $\mathrm{PhD}$ thesis broadly covering the representation of colonial women in museums across major cities in Australia, and how this practice might translate into my own creative work curating an exhibition highlighting the autonomy of European women who travelled to early Western Australia. The purpose of this fieldwork was to investigate how industry practice was reflecting well-worn and accepted feminist scholarship in the recognition of women in Australian history and translating these stories and practice into museology for the populace. Opportunities to access a broad range of museums are limited in Western Australia, so it was decided that fieldwork could most effectively be conducted in major cities in eastern Australia, where there are multiple galleries in a relatively small area. Therefore, fieldwork was localised to museums and galleries in Melbourne, Sydney and around the Hobart area in September 2017. State and local government institutions, as well as some community or privately funded museums were included in order to understand trends in the representation of women in galleries across the sector. ${ }^{8}$

6 Elizabeth Wood and Kiersten F Latham, The Objects of Experience: Transforming Visitor-Object Encounters in Museums (Walnut Creek: Routledge, 2016), 24.

7 These are, of course, European women - mostly middle-class educated British women—whose experiences of the frontier was vastly different to those of other classes, races or nationalities, let alone Aboriginal or Torres Strait Islander women who (for brevity) are not covered in this paper.

8 Both museums and art galleries were included in the fieldwork. 
While some sites and exhibitions were chosen due to their content being anticipated to relate to the research topic, in the first instance institutions were chosen mainly because of their practice. For example, while the Cascades Female Factory near Hobart seemed a natural choice for the project due to the institution's focus on the representation of women in a colonial context, valuable information about audience positioning and interactive design techniques was also found at the temporary exhibition 'The Pool' at The Ian Potter Centre, National Gallery of Victoria (NGV) Australia in Melbourne, which displayed an altered version of the Australian exhibition displayed at the 2016 Venice Architecture Biennale. ${ }^{9}$ Exhibition content was also considered, with preliminary research having identified some permanent and temporary exhibitions related to the experiences of women in Australia, and more specifically those in a colonial context. Case studies in this paper include Melbourne Museum, Allport Library and Museum in Hobart, and the Museum of Applied Arts and Sciences in Sydney. Melbourne Museum was selected as a case study due to their all-encompassing permanent exhibition content, from Bunjilaka Aboriginal Cultural Centre through to natural and broader social history displays. ${ }^{10} \mathrm{~A}$ section of the 'Evolution' gallery, which illustrated colonial scientific study, will be discussed as a case study later in this paper. Similarly, 'Bird Woman', a temporary exhibition at Allport Library and Museum within the State Library of Tasmania, was selected for similar themes of scientific work in colonial Australia, and explored the works of artist Elizabeth Gould in a contrasting fashion to Melbourne Museum's display. ${ }^{11}$ Lastly, the Museum of Applied Arts and Sciences (Powerhouse Museum) in Sydney was selected for their range of permanent social history exhibitions, as well as the 'Love Is ... Australian Wedding Fashion' temporary exhibition, which displayed some early colonial wedding dresses and provided consideration of the treatment and display of colonial female bodies within exhibition spaces. ${ }^{12}$

9 'Cascades Female Factory', Port Arthur Historic Site Management Authority, www.female factory.org.au; 'The Pool', The Ian Potter Centre, NGV Australia, 18 August 2017 - 18 February 2018, www.ngv.vic.gov.au/exhibition/the-pool/.

10 'Melbourne Museum', Museums Victoria, museumsvictoria.com.au/melbournemuseum/.

11 'Bird Woman', Allport Library and Museum of Fine Arts (State Library of Tasmania), 8 September 2017 - 27 January 2018.

12 'Love Is ... Australian Wedding Fashion', 13 May 2017 - 20 May 2018, Museum of Applied Arts and Sciences, maas.museum/event/love-is-australian-wedding-fashion/. 


\section{Historical and Theoretical Background}

Spicer's words felt pertinent to my fieldwork, particularly as gallery after gallery were scanned in the search for an autonomous female perspective, which was certainly there, but was overwhelmed with what I was beginning to recognise as a pervasive gender gap in both written and physical recognition within museums. Specifically, colonial women existed in the Australian history on display while men acted. ${ }^{13}$ This was reiterated by exhibition text that either largely sidelined their achievements, presented women solely within the context of their husbands or male guardians, or through the physical misrepresentation of colonial women's bodies on display. This exists in stark contrast to the well-established academic feminist historiography related to colonial women in Australia that has been developing since the 1970s. From the latter half of the twentieth century, historians such as Anne Summers, Miriam Dixon, Eve Pownall, Susanna de Vries and Deborah Oxley (among many others) wrote provocative and influential accounts of women's history in Australia that lay the foundation of feminist historiography in this country. ${ }^{14}$ Further, a focus on the diversity of histories about colonial (free, indentured or convict) women in Australia were popularised in academia from the 1990s and had a broad reach into the public sphere through education and popular discourse. ${ }^{15}$ The rise of

\footnotetext{
13 John Berger, Ways of Seeing (London: Penguin Books, 1972), 47.

14 See: Susanna De Vries, The Complete Book of Heroic Australian Women: Twenty-one Extraordinary Women whose Stories Changed History (Sydney: Harper Collins Publishers, 2010); Miriam Dixon, The Real Matilda: Woman and Identity in Australia 1788 to 1975 (Ringwood: Penguin Books, 1976); Deborah Oxley, Convict Maids: The Forced Migration of Women to Australia (Cambridge: Cambridge University Press, 1996); Eve Pownall, Australian Pioneer Women, 3rd ed. (Melbourne: Rigby Limited, 1964); Anne Summers, Damned Whores and God's Police, 2nd revised ed. (Melbourne: Penguin Books, 2002).

15 See Alison Alexander, The Ambitions of Jane Franklin: Victorian Lady Adventurer, 2nd ed. (Sydney: Allen \& Unwin, 2016); Rica Erickson, The Bride Ships: Experiences of Immigrants Arriving in Western Australia 1849-1889 (Perth: Hesperian Press, 1992); Jane Long, Jan Gothard and Helen Brash, eds., Forging Identities: Bodies, Gender and Feminist History (Perth: University of Western Australia Press, 1997); Raelene Frances and Bruce Scates, Women at Work in Australia: From Gold Rushes to World War II (Cambridge: Cambridge University Press, 1993); Raelene Frances, Selling Sex: A Hidden History of Prostitution (Sydney: UNSW Press, 2007); Raelene Frances, The Politics of Work: Gender and Labour in Victoria 1880-1939 (Cambridge: Cambridge University Press, 1993), doi.org/10.1086/ahr/101.1.228-a; Lucy Frost, No Place For A Nervous Lady: Voices from the Australian Bush (Melbourne: McPhee Gribble Publishers, 1984); Jan Gothard, Blue China: Single Female Migration to Colonial Australia (Melbourne: Melbourne University Press, 2001); Penelope Hetherington, Herstories - Our History: Bibliography of Western Australian Women's History (Perth: Edith Cowan University, 1998); Penelope Hetherington, Settlers, Servants \& Slaves: Aboriginal and European Children in Nineteenth-century Western Australia (Perth: University of Western Australia Press, 2002), doi. org/10.2307/27515946; Penelope Hetherington and Phillipa Maddern, eds., Sexuality and Gender in History: Selected Essays (Perth: Centre for Western Australian History, University of Western Australia, 1993); Susan Hunt, Spinifex and Hessian: Women in North-West Australia, 1860-1900 (Perth: University of Western Australia Press, 1986); Siân Rees, The Floating Brothel: The Extraordinary True Story of an 18thcentury Ship and its Cargo of Female Convicts, 2nd ed. (Sydney: Hodder Headline Australia, 2002), doi. org/10.2307/27516857; Patricia Crawford and Philippa Maddern, eds., Women as Australian Citizens: Underlying Histories (Melbourne: Melbourne University Press, 2001).
} 
feminist histories from the late twentieth century illuminated Australian women's experiences in the colonial archive-describing in their own words, in letters, diaries and personal communication, their lives on the Australian frontier, and highlighting their autonomy.

Since the 1970s, museums have undergone significant cultural change, not least in embracing the 'history from below' movement mirrored in the democratisation of social history in academia. ${ }^{16}$ Alison Bartlett and Margaret Henderson, Australian academics involved with the National Library of Australia's 2013 symposium 'Feminism and the Museum', argue that in line with this 'history from below' movement, feminism deserves 'a place in the museological production of social memory'. ${ }^{17}$ Feminist research in museums is a fledgling discipline, but significant research has addressed varied concerns about depictions of women in exhibitions, and their representation in narratives of cultural heritage. ${ }^{18}$ Amongst this research, there is a common focus on how museum materialities, as Arndís Bergsdóttir refers to them, as well as gendered power relations, conventionally place male figures at the centre of museum narratives. ${ }^{19}$ British museum consultant and academic Gaby Porter argues that these museum materialities, including text, objects and design, which reduce or omit women from exhibition spaces not only occur at a curatorial level, but within museum processes and deeper knowledge production-in turn affecting how objects are categorised, interpreted and employed within exhibition spaces and museum collections. ${ }^{20}$ Further, Porter has argued,

16 Alison Bartlett and Margaret Henderson, 'Feminism and the Museum in Australia: An Introduction', Journal of Australian Studies, 40, no. 2 (2016): 130-2.

17 Ibid., 132.

18 See Bartlett and Henderson, 'Feminism and the Museum in Australia', 129-39; Arndís Bergsdóttir, 'Museums and Feminist Matters: Considerations of a Feminist Museology', NORA - Nordic Journal of Feminist and Gender Research, 24, no. 2 (2016): 126-39, doi.org/10.1080/08038740.2016.1182945; Katy Deepwell, 'Feminist Curatorial Strategies and Practices since the 1970s', in New Museum Theory and Practice, ed. Janet Marstine (Chichester: Wiley-Blackwell, 2008), doi.org/10.1002/9780470776230. ch2; Amy K Levin, ed., Gender, Sexuality and Museums: A Routledge Reader (New York: Routledge, 2010); Jane R Glaser and Artemis A Zenetou, eds., Gender Perspectives: Essays on Women in Museums (Washington DC: Smithsonian Institution Press, 1994); Viv Golding, 'Museums, Poetics and Affect', Feminist Review, 104, no. 1 (2013): 80-99, doi.org/10.1057/fr.2013.2; Hilde Hein, 'Looking at Museums from a Feminist Perspective', in Gender, Sexuality and Museums: A Routledge Reader, ed. Amy K Levin (Oxon, UK: Routledge, 2010), 53-64, doi.org/10.4324/9780203847770; Hilde Stern Hein, 'Redressing the Museum in Feminist Theory', Museum Management and Curatorship, 22, no. 1 (2007): 31-4, doi.org/10.1080/09647770701264846; Gaby Porter, 'Seeing through Solidity: A Feminist Perspective on Museums', The Sociological Review, 43, no. S1 (1995): 105-26, doi.org/10.1111/j.1467954x.1995.tb03427.x.

19 Bergsdóttir, 'Museums and Feminist Matters', 128.

20 Porter, 'Seeing through Solidity', 105-26. 
even curators who have addressed this gender imbalance have themselves largely reinforced cultural assumptions of gender. ${ }^{21}$ Their exhibitions tend to reduce women to traditionally passive or shallow roles, idealising women who fitted the mould, and leaving behind those deemed to be more 'difficult'. Alternatively, they have granted these 'difficult' women a disproportional focus inside exhibition narratives - such as those outstanding, royal or criminal women of the most popular displays. ${ }^{22}$ This is accomplished through both language, with crafted exhibition text, and physical design; the deliberate selection of objects, their placement, and representation of figures in galleries, which also contribute to visitor-made meaning within the gallery.

The physical representation used by curators and designers to characterise historical figures in museums and galleries tells their audience almost as much as the written content in text panels and object labels. Exhibition elements are imbued with varying social meaning and qualitative cultural information, while the gaps are filled with text, to generate and reproduce collective knowledge within the viewer. ${ }^{23}$ Museum objects are largely 'mute and unreadable' to visitors without some form of curatorial explanation and narrative involvement. ${ }^{24}$ The cohesive positioning and location of objects, and collective exhibitions within the walls of the museum, communicate much more than is written on text panels, or explained through object labels, and has a profound social impact through its display. Therefore, it is unavoidable that there are intrinsic social assumptions and beliefs, influenced by culture, within gallery representations. ${ }^{25}$ Museum practices reflect the society in which they are placed. In a Western context, this has resulted in colonial, imperialist and masculinist interpretations being privileged. ${ }^{26}$ Numerous academics across disciplines have argued that in Western patriarchal societies, 'men have controlled who looks

\footnotetext{
21 Ibid., 108-9.

22 Ibid.

23 Hilde Hein, quoted in: Michelle Henning, Museums, Media and Cultural Theory (Maidenhead, England: Open University Press, 2006), 6-7; Adrian B Evans, 'Enlivening the Archive: Glimpsing Embodied Consumption Practices in Probate Inventories of Household Possessions', Historical Geography, 36 (2008): 44; Bartlett and Henderson, 'Feminism and the Museum in Australia', 131; Susan A Crane, 'The Conundrum of Ephemerality: Time, Memory, and Museums', in A Companion to Museum Studies, ed. Sharon Macdonald (Chichester: Wiley, 2008), 99.

24 Katherine Louise Gregory, 'The Artist and the Museum: Contested Histories and Expanded Narrative in Australian Art Museology, 1975-2002' (PhD, University of Melbourne, 2004-10), 267.

25 Usha Bande, 'Introduction', in Boundaries of the Self: Gender, Culture and Spaces, ed. Debalina Bannerjee (Newcastle-upon-Tyne: Cambridge Scholars Publishing, 2014), 4.

26 Hein, 'Looking at Museums from a Feminist Perspective', 53-64.
} 
at whom'. ${ }^{27}$ Due to this overarching influence, it's not only men who do the looking, but society as a whole has been provided with what Beth Eck has labelled 'readily available cultural scripts' for interpreting and responding to femininity on display. ${ }^{28}$ Therefore, it is not just the curatorial and exhibition design that influences the visitor, but also their own social and cultural conditioning that guides their interpretation of the museum narrative. Further, it must be acknowledged that meaning is made as much by curatorial intent and carefully considered design, as by the social values and beliefs of the audience. This means that in both museum collections, and in the public exhibitions that utilise these objects, it is the museum staff who influence the narrative that depicts the wives, sisters and, daughters (and mistresses) of great men as footnotes to masculine achievement. In an Australian context, these women have become mere additions to the narrative of progress that marched across this declared-empty continent.

\section{A Study of Language: Exhibiting Elizabeth Gould}

The striking difference in curatorial language used to illuminate the life and work of Elizabeth Gould, a colonial-era scientific artist, highlights the power of words within an exhibition to both reflect and influence visitormade meaning within the museum, and wider social understandings of historical women in Australia. Gould featured in both a permanent natural history display at Melbourne Museum, and a temporary exhibition titled 'Bird Woman' at Allport Library and Museum of Fine Arts (State Library of Tasmania) in Hobart, on display from September 2017. ${ }^{29}$ In both galleries, Gould was presented as the wife of John Gould, whose publication Birds of Australia was a definitive nineteenth-century text on native ornithology in this country. Traditionally, Gould's work was overshadowed by her husband who assumed credit for her artistic work after her death, effectively

27 See: Rosalind Coward, Female Desires: How They Are Sought, Bought and Packaged (New York: Grove Weidenfeld, 1985); Melody D Davis, The Male Nude in Contemporary Photography (Philadelphia: Temple University 1991); Berger, Ways of Seeing.

28 Beth A Eck, 'Men Are Much Harder: Gendered Viewing of Nude Images', Gender and Society, 17, no. 5 (2003): 691-3.

29 'Evolution Gallery', Melbourne Museum; Jess Walters, 'Bird Woman: Elizabeth Gould and the Birds of Australia', Tasmanian Archive and Heritage Blog, 7 November 2017, archivesandheritageblog. libraries.tas.gov.au/bird-woman-elizabeth-gould-and-the-birds-of-australia/. 
removing her contribution from historical memory. ${ }^{30}$ The permanent, and arguably out-dated, display at Melbourne Museum reinforces this narrative by giving little recognition to Gould's accomplishments as an artist, instead emphasising her domestic work as a wife and mother. ${ }^{31}$ Alternatively, Allport Library and Museum characterises Gould as an artist in her own right, who developed her craft through travel with her husband and honed her scientific observation while in Tasmania in order to produce the acclaimed imagery in her husband's publication. ${ }^{32}$ The difference in characterisation in these exhibitions is significant because it highlights the impact of interpretation of a single subject through language, and reflects the changes in museum practice towards greater inclusivity of feminist historiography and acceptance in wider historical memory in Australia.

Choices in exhibition language have relegated Elizabeth Gould, a prolifically talented scientific artist in her own right, to a secondary figure alongside her husband John Gould, who is glorified in the natural history display at Melbourne Museum. ${ }^{33}$ Although an accomplished artist who produced a large number of lithographs and prints of Australian birds for publication in her husband's book, Birds of Australia, Gould is not the feature of the display. ${ }^{34}$ The language of the text panel featuring Gould highlights (in bold text) her perceived key achievement: 'Elizabeth Coxen married John Gould in 1829'. ${ }^{35}$ On the other hand, John Gould's achievements are lauded; his illustrations and scientific plates are cited as 'magnificent works of art and important scientific documents'. ${ }^{36}$ The objects chosen to accompany these pieces of text include illustrations from the large-scale scientific publication, as well as tickets to the Gould's exhibition of hummingbirds in London. ${ }^{37}$

The juxtaposition of language clearly positions John Gould as the hero, emphasising his production of Birds of Australia as more significant than Elizabeth's Gould's domestic work. The language used in text panels about

\footnotetext{
30 Walters, 'Bird Woman'.

31 'Evolution Gallery', Melbourne Museum.

32 'Bird Woman', Allport Library and Museum of Fine Arts.

33 'Evolution Gallery', Melbourne Museum.

34 'Gould, Elizabeth (1804-1841)', Australian National Herbarium, last updated 11 September 2013, www.anbg.gov.au/biography/gould-elizabeth.html; AH Chisholm, 'Gould, Elizabeth (1804-1841)', Australian Dictionary of Biography, published first in hardcopy 1966, adb.anu.edu.au/biography/ gould-elizabeth-2112/text2665.

35 'Evolution Gallery', Melbourne Museum.

36 Ibid.

37 Ibid.
} 
John Gould tie him more significantly to the objects on display, while the lesser amount of text about Elizabeth Gould notes her (secondarily) as a contributing artist. ${ }^{38}$ No other mention of Elizabeth Gould was found in the gallery. A single coloured portrait was the only other physical evidence of her existence. ${ }^{39}$ Through this curatorial narrative, Elizabeth Gould's contribution is minimised-sidelined with domesticity as her focus, and overpowered by the significance placed on her husband's contributions outside of the home and their marriage. The selection of curatorial design to emphasise the text about her marriage, rather than the large number of scientific illustrations she produced, aligns with the gendered expectations of nineteenth-century colonial women. This traditional approach to women's representation in Australian history means that, to a visitor of this exhibition, Elizabeth Gould's existence and her historical significance is defined by her relationship to her husband. Her autonomy is reduced by this narrative of dependency upon him for recognition, and reinforces the traditional gender bias in Australian public memory.

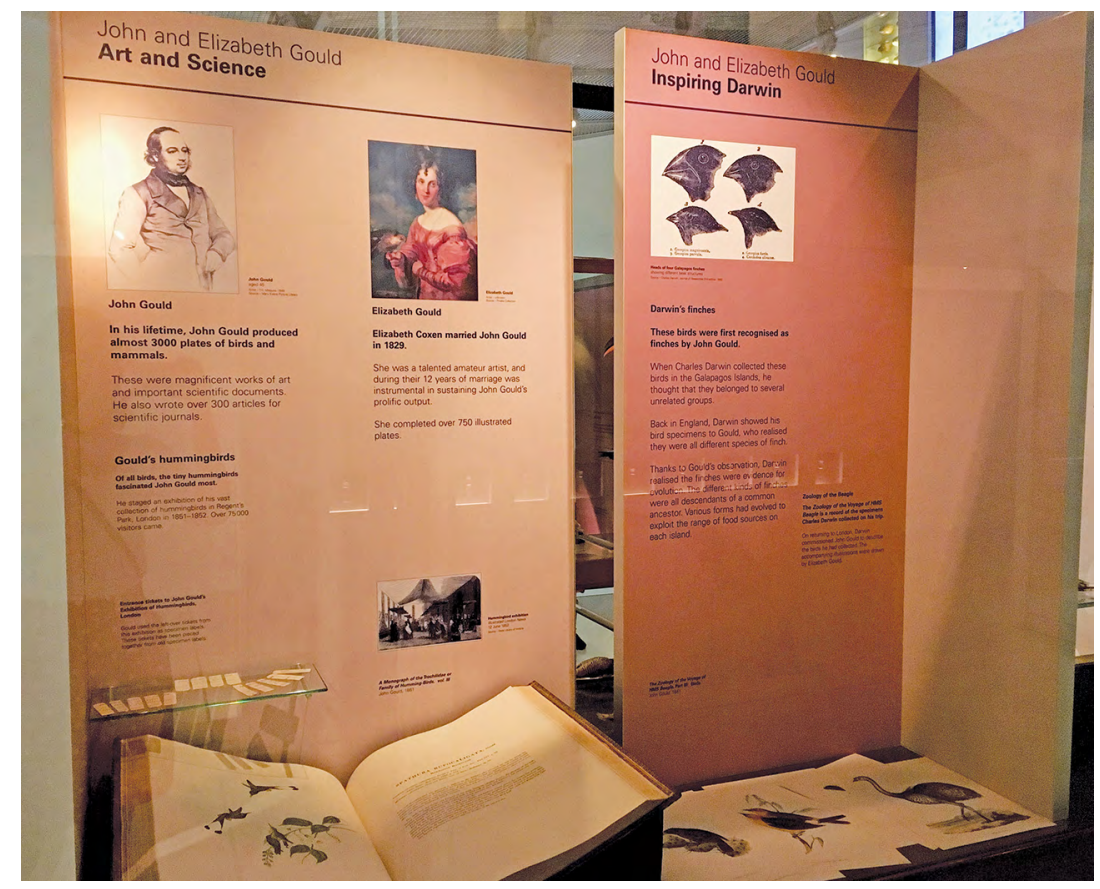

Figure 1: Melbourne Museum, 2017.

Source: Toni Church. 
In 2017, Allport Library and Museum of Fine Arts in Hobart provided an alternative interpretation of the role of Elizabeth Gould. The 'Bird Woman' exhibition presented the Gould's artistic works and implements, with very similar objects to those on display in Melbourne Museum, but with a narrative weighed heavily in favour of Elizabeth Gould. ${ }^{40}$ The introductory text panel at the entrance of the gallery acknowledged that her 'role in the production of Gould's books has been understated and overlooked'. ${ }^{41}$ This explicit acknowledgement of the historical silence surrounding Elizabeth Gould's contribution frames the exhibition as both an exercise in truth-telling, and brings this history into line with now-accepted historical understandings of the contribution of women in the colonial era. The panel went on to articulate the main theme of the exhibition by stating that 'Elizabeth Gould the Birdwoman was the equal partner in life and work to John Gould the Birdman', a stark departure from the traditional trope. ${ }^{42}$ Further curatorial interpretation gave reasons for Elizabeth Gould's limited notoriety; text panels summarised how the gendered expectations of nineteenth-century womanhood had hidden Elizabeth Gould's 'artistic endeavours ... within the family home and business', while also noting that her early death at 37 further obscured her role, and allowed for her husband to assume credit for her works in his publications. ${ }^{43}$ The conscious framing of Elizabeth Gould as a significant contributor to her husband's publications through careful selection of language provides a powerful statement on the role of women in colonialera scientific productions in Australia. Allport Library and Museum directly address the gender imbalance in this historical memory, with their curators using direct and unambiguous language to frame Elizabeth Gould as a significant scientific artist in her own right. In doing so, they have strongly contributed to redressing the historical imbalance in the Australian collective memory of colonial women.

There is a marked difference in the nature of both the curation and display of the two exhibitions in Melbourne and Hobart. ${ }^{44}$ In the case of Elizabeth Gould, it is not the objects but the textual interpretation that simultaneously sidelines and highlights her contribution. The objects are

\footnotetext{
40 'Bird Woman', Allport Library and Museum of Fine Arts.

41 Ibid.

42 Ibid.

43 Ibid.

44 Admittedly, the Melbourne Museum display has not aged well, and represents the challenges of museums to maintain their currency amidst a changing social and cultural landscape. Their updated gallery spaces, within the same building, are recognised as leading examples of industry excellence.
} 
the same. The history is the same. However, the methods and manner of interpretation provide the audience with vastly different meanings. This gendered bias at once reinforces preconceived notions of women's role in scientific advancement through the positioning of Elizabeth Gould's narrative as secondary to her husband. Further, it cements any of her achievements as wholly reliant upon him. Other Australian exhibitions have addressed similar themes, such as Sydney Living Museums' 2016 exhibition 'The Artist \& the Botanical Collector' about the publishing partnership between Gertrude Lovegrove and William Bäuerlen. Framed as a coming together of equal minds, Lovegrove the artist and Bäuerlen the collector pursued the ambitious (but ultimately unsuccessful) multipart publication of The Wild Flowers of New South Wales. ${ }^{45}$ The Australian Museum's current touring exhibition 'Transformations: Art of the Scott Sisters' seeks to further highlight the contribution of women in the production of scientific illustrations in colonial Australia. ${ }^{46}$ Placing the works of Harriet and Helena Scott as the subject of this exhibition, the accompanying text characterises them as 'two of 19th-century Australia's most prominent natural history illustrators ${ }^{4}{ }^{47}$ By pointedly not qualifying their gender in this statement, the curators give weight to the Scotts' contribution to the scientific world as equal and deserving of attention based on their skills, not the extraordinary nature of their behaviour given the gendered expectations of their time. Somewhat subtle but powerful adjustments in language used in exhibitions and publicity materials affects visitor's perceptions of curatorial subjects in museums. By reflecting on choices of language, museums are contributing to popular discourse and understandings of Australian historical memory; and, in the case of Elizabeth Gould, are both continuing the trend of feminist historiography in academia, and directly influencing the increasing recognition of the roles of women in colonial Australia.

45 'The Artist \& The Botanical Collector: The Lost Works of Lovegrove \& Bäuerlen', Museum of Sydney (Sydney Living Museums), 13 August 2016 - 20 November 2016, sydneylivingmuseums. com.au/exhibitions/artist-botanical-collector.

46 'Touring exhibition: Transformation: Art of the Scott Sisters', Australian Museum, 2020, australianmuseum.net.au/get-involved/services/touring-exhibits/transformations-art-of-the-scottsisters-exhibition/.

47 Ibid. 


\section{A Study of the Physical: Mannequin Bodies}

Clothing presents vast potential for interpretation, particularly in exhibitions focusing on the individual stories and historical imprint of women, as it enables visitors 'to make tangible, meaningful mental links with the past'. ${ }^{48}$ The embodied nature of costume collections enables a more personal connection with the audience. ${ }^{49}$ Displaying costume collections in a manner that is authentic to the historical figures being represented is a challenge. Ingrid Mida, Fashion Research Collection Coordinator at Ryerson University, has investigated the challenge posed to costume curators whose collections and exhibitions must communicate that a dress artefact was once worn by a living person and therefore embodies a complex interplay of cultural beliefs, identity, memory, and body imprints. ${ }^{50}$ The interpretive designs for standard objects and artefacts, such as display cases or plinths, do not allow for the accurate embodiment of clothing items in order to flesh out the person who once wore the costume, and produce an emotional affect with the audience. In lieu of the live bodies who wore the clothing, mannequins have become the industry standard design feature that 'bring to life' costume collections, using a constructed bodily form to make an inextricably human connection between visitor and object.

When mannequins take a female form within a museum gallery, the bodies on display are perceived by visitors with the same cultural consciousness as women in their society. The mannequin form itself, when not on display, does not purvey particular meaning to an absent audience. However, when that feminised figure is curated, accompanied by a design aesthetic, recognisable social indicators such as pose and accessorised in such a way as to produce meaning, the impact of these social and cultural marks becomes clearly evident. Put simply, when women are displayed within the walls of a gallery, they become an object. Whether represented by painting, material culture or modelled figure mannequins, these women are imbued with cultural significance and interpreted by cultural values. ${ }^{51}$

48 Julia Petrov, 'Cross-Purposes: Museum Display and Material Culture', CrossCurrents, 62, no. 2 (2012): 223.

49 Laura Neilson, 'How Museums and Cultural Institutions Have Shaped the History of Body Diversity,' Fashionista, 6 December 2017, fashionista.com/2017/12/mannequins-fashion-museumfit-body-exhibit.

50 Ingrid Mida, 'Animating the Body in Museum Exhibitions of Fashion and Dress', The Journal of the Costume Society of America, 41, no. 1 (2015): 38, doi.org/10.1179/0361211215z.00000000038.

51 Laura Mulvey, 'Dossier: Visual Pleasure at 40', Screen, 56, no. 4 (2015): 481-2; Laura Mulvey, 'Visual Pleasure and Narative Cinema', Screen, 16, no. 3 (1975): 6-18; Berger, Ways of Seeing. 
Amy Levin, Professor of Museum Studies at Northern Illinois University, has commented that 'regardless of the type of museum, its objects become subjects of gaze', with museums taking their place as a 'cultural apparatus' instructing visitors in approved culture and behaviours-including how to view female bodies. ${ }^{52}$ Feminine mannequins are laden with these cultural signposts, designed and posed as idealised female forms.

Such posing and perfecting of the female form is in stark contrast to a mannequin's purpose to display costume collections worn by real women, many of whom did not perform to social or cultural ideals, and produces a clash between the curatorial intent in displaying a costume object, on a socially ill-fitting mannequin form, which can result in an unintended perception of the curatorial subject by visitors. Visitors view the costume object through a lens of their own cultural, social and personal experiences, which means their perception of the curatorial subject is heavily influenced by the physical form on which it is displayed. As Joanne Entwistle highlighted, 'our experience of the body [within a gallery setting] is not as inert object but as the envelope of our being, the site for our articulation of self', for which curatorial and exhibition design staff are not immune. ${ }^{53}$ The distinct relationship between body and identity, and identity and dress, must be understood and then applied with care by those in museums who hold the power to influence the meaning-making of an exhibition. Understanding and working with this cultural and social interrelationship of feminised bodies in gallery spaces and visitor perception, is crucial when curating accurate representations of real women in museum exhibitions.

The contradiction between design and historical accuracy was observed through the exhibition design choices that posed colonial women as demure, shy, downward-facing mannequins in the Museum of Applied Arts and Sciences' (Powerhouse Museum, Sydney) 'Love Is ... Australian Wedding Fashion' exhibition in 2017.54 In this exhibition, colonial wedding dresses were displayed on fine-figured, almost child-like, mannequin dress forms with stylised hair and gentle features, standing with arms softly placed in passive positions. ${ }^{55}$ The mannequins had clearly

52 Amy K Levin, 'Introduction', in Gender, Sexuality and Museums: A Routledge Reader, ed. Amy K. Levin (Oxon, UK: Routledge, 2010), 5, doi.org/10.4324/9780203847770.

53 Joanne Entwistle, 'Fashion and the Fleshy Body: Dress as Embodied Practice', Fashion Theory, 4, no. 3 (2000): 335, doi.org/10.2752/136270400778995471.

54 'Love Is ... Australian Wedding Fashion'.

55 Ibid. 
been designed and positioned to adopt a stereotypical female personality of the nineteenth century. Small and diminutive in both physicality and behaviour, they projected a gentle demeanour, not taking up a lot of space with their bodies, and certainly not behaving as assertive figures. The mannequin's pose added another layer of character and personality to both the costume and the historical figure the curator represented in the exhibition. Pose is an important aspect of telling exhibition stories and creating meaning by mirroring human behaviour, and further engaging visitors through the embodiment of costume collections. ${ }^{56}$ However, the poses used to display these colonial wedding dresses did not fully communicate the complexities of the historical figures. Rather, they reinforced the stereotypical, sociocultural assumptions about nineteenthcentury colonial women in Australia, strengthening a narrative that is both inaccurate and damaging to the equal recognition of women's contributions in Australian collective memory.

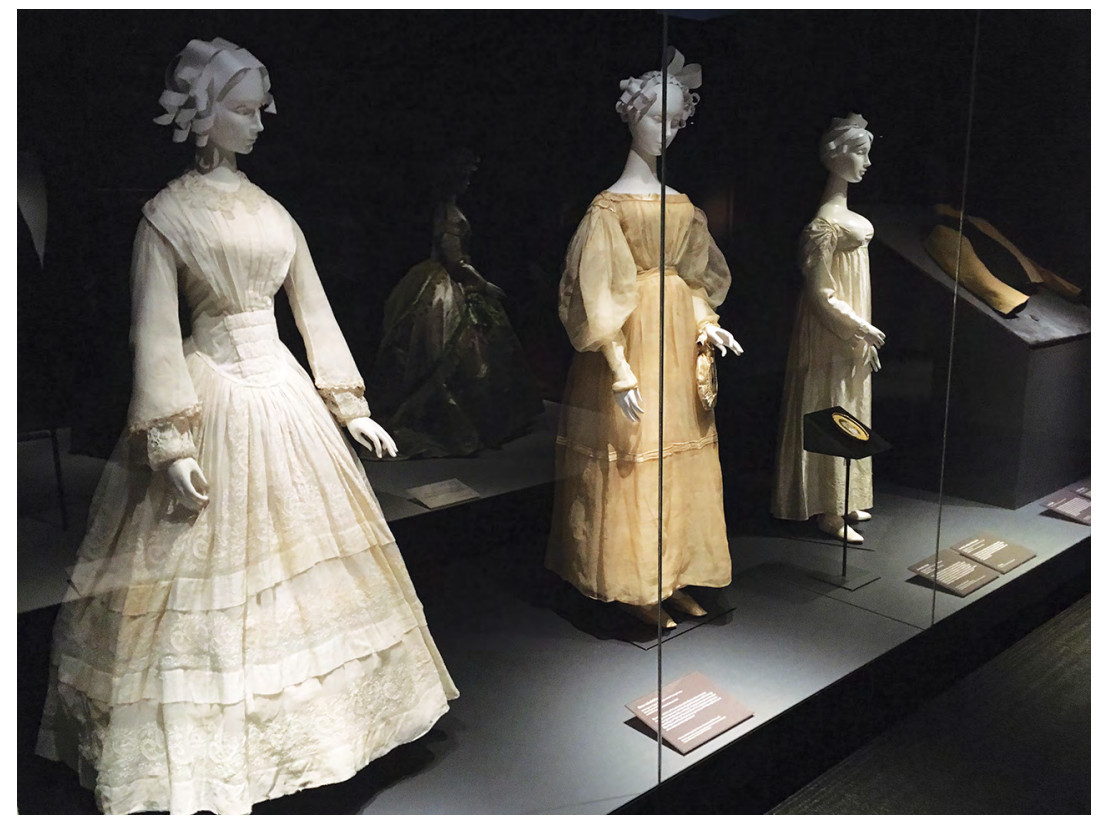

Figure 2: 'Love Is ... Australian Wedding Fashion', Museum of Applied Arts and Sciences, 2017.

Source: Toni Church.

56 Shelly Uhlir, 'Articulated Solutions for Mannequins in the Circle of Dance Exhibition at National Museum of Ths American Indian - New York', Journal of the American Institute for Conservation, 56, no. 1 (2017): 53, doi.org/10.1080/01971360.2016.1269552. 


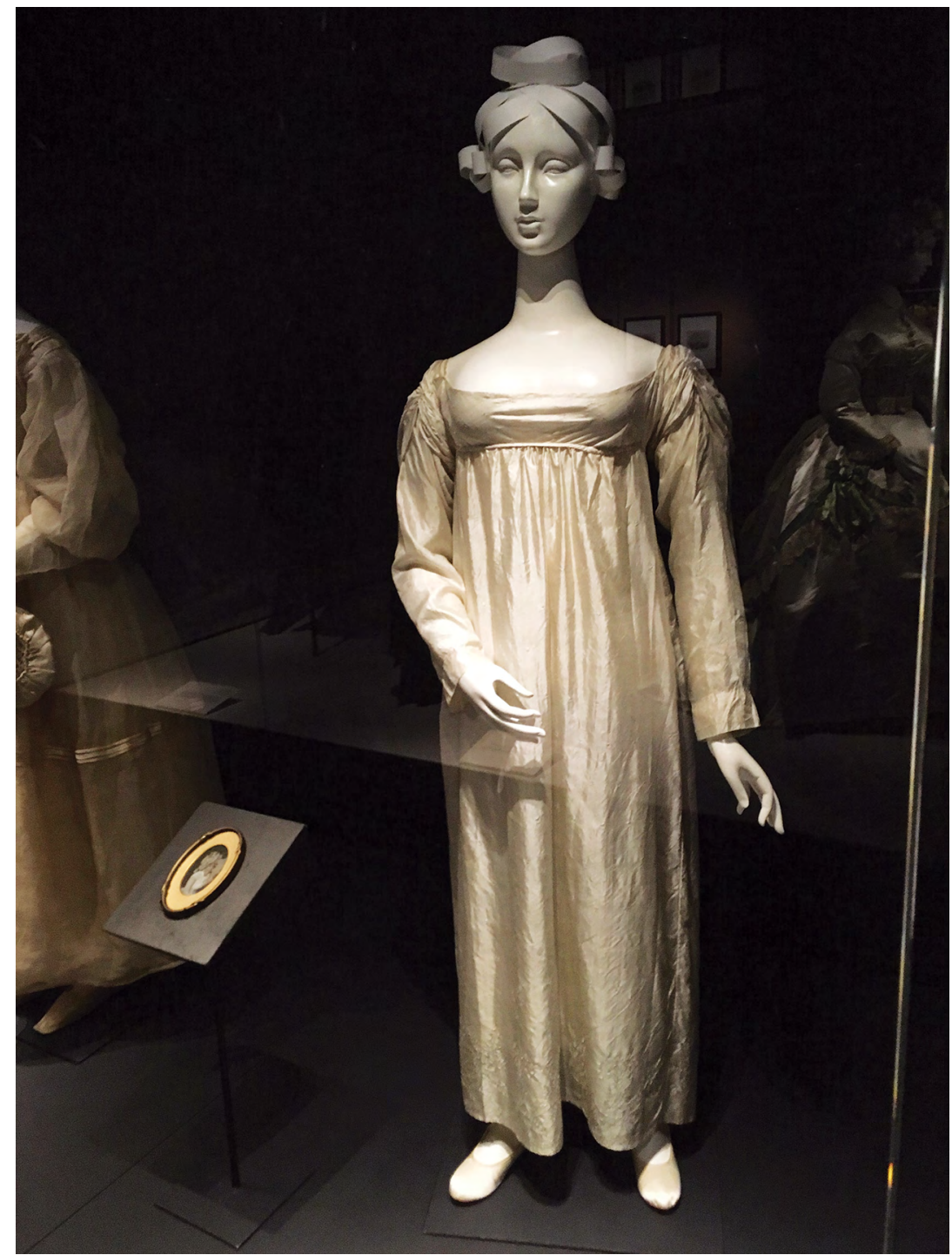

Figure 3: Australia's oldest surviving wedding dress, 'Love Is ... Australian Wedding Fashion', Museum of Applied Arts and Sciences, 2017.

Source: Toni Church.

There were sparse details included in the exhibition text about the women who wore these dresses, but further research indicated that these were vibrant, adventurous and generous colonial women whose personalities are not accurately portrayed by the posed figures hosting their dresses. Believed to be Australia's oldest surviving wedding dress, the pictured 
popular neoclassical style of gown is provenanced to Ann Marsden who married Reverend Thomas Hassall in Parramatta in 1822, but its display does not convey the courageous story of the generations of women who wore this dress. ${ }^{57}$ At a glance, the visitor may recognise the age of the gown, but will also perceive the type of woman who wore this dress. From the mannequin's soft and open hand gestures, delicately moulded facial features and crafted 'hair', the gentle persona (and European race) being conveyed by the mannequin design is clear. While this gentle personality may befit the original owners of this dress, the passivity of the mannequin's presence and pose in this display belies the difficulties endured by its wearers in their life on the colonial frontier. The absence of these colonial women's active and autonomous contributions to the processes of colonisation in this space perpetuates popular misunderstandings of women's experiences of the frontier, and the significant role they had in the settlement of Australia.

The dress was originally worn by Ann Marsden's mother Elizabeth Marsden (née Fristan) in her marriage to Samuel Marsden in April $1793 .{ }^{58}$ It appears that Elizabeth Marsden brought her wedding dress with her later that year when she travelled from England to Sydney with her husband-a priest destined for the new colony at Parramatta — giving birth to her first child, Ann, on the voyage, during a wild storm off the coast of Tasmania. ${ }^{59}$ While her husband attempted farming, despite his inexperience, as well as the evangelising of convicts and Aboriginal people, Elizabeth Marsden raised five daughters and a son in challenging environmental and social circumstances. Her husband's missionary work in Norfolk Island and New Zealand (over seven voyages) took him away from the family, leaving her isolated in the raising of the family. His reputation as a harsh colonial magistrate and his staunch opposition to the colonial government surely made for an uncomfortable social predicament, at best, for his wife. ${ }^{60}$ The style and typical pose of mannequin used to display the dress does little to embody both Elizabeth's, and later her daughter Ann's, intrepid

57 Lydia Edwards, How to Read a Dress: A Guide to Changing Fashion from the 16th to the 20th Century (London: Bloomsbury Academic, 2017), 68; 'Love Is ... Australian Wedding Fashion'.

58 'Love Is ... Australian Wedding Fashion'; Glynis Jones, 'Love is ... Highlights from the MAAS Wedding Dress Collection', Museum of Applied Arts \& Sciences, 13 February 2018, maas. museum/inside-the-collection/2018/02/13/love-is-highlights-from-the-maas-wedding-dresscollection/; AT Yarwood, 'Marsden, Samuel (1765-1838)', Australian Dictionary of Biography, adb. anu.edu.au/biography/marsden-samuel-2433.

59 AT Yarwood, 'Marsden, Samuel (1765-1838)'.

60 Ibid. 
bravery or personify their experiences on the colonial frontier. Overall, the uniformity of the demure mannequin design promotes a homogenous colonial experience for women and does not embody the complexities of personality or experiences of the original wearers of these garments.

\section{Curating Enlivened and Embodied Exhibitions}

The challenge for cultural heritage professionals, then, is how to accurately represent the former owner's full lived experience through the display of their collection. Challenging established social and cultural expectations, just as many of these colonial women did, is a key step in order to more fully embody their stories with action, autonomy and a more accurate representation of their lives on the frontier. What is remembered is important, but it is also the way history is remembered. How women are represented is just as important as their inclusion in the collective narrative. By embracing pluralism beyond merely tokenistic representations of women within exhibition narratives and curatorial selection, but also redressing the engrained notions of subjectivity within museum's processes and roles, museums have the potential to shift the perspectives of not just their content, but the perspectives and understandings of its audiences. ${ }^{61}$ There has been, and continues to be, a distinct shift in the way colonial narratives are told in this country. As we transition into a postcolonial society (with much work to come), the narrative of the frontier is becoming more inclusive-as it always was, but not always as it has been collectively remembered. By recognising that museums have traditionally been characterised by patriarchal barriers and controls, museum professionals have played a key role in initiating a transformation of this characterisation; initiating discussions of gender and inequality in the museum by exhibiting richer and more challenging histories. ${ }^{62}$ However, this transformation is still incomplete.

61 Bergsdóttir, 'Museums and Feminist Matters', 128; Hilde Stern Hein, 'Redressing the Museum in Feminist Theory', Museum Management and Curatorship, 22, no. 1 (2007): 31-4, doi. org/10.1080/09647770701264846.

62 Golding, 'Museums, Poetics and Affect', 81; Gaynor Kavanagh, Museum Provision and Professionalism (London: Routledge, 1994); Bergsdóttir, 'Museums and Feminist Matters', 129. 
Certainly, a shift in visitor perception led by curatorial and design influences is key. Providing audiences with more inclusive narratives through language and recognising the active role women played in processes of colonisation has been achieved in galleries such as Allport Library and Museum by repositioning female-driven narratives to the forefront of exhibition planning. ${ }^{63}$ This narrative shift aligns more fully with the lived experience of colonial women on the frontier, but also mirrors the evolution of feminist historical scholarship on these topics. From fieldwork conducted in exhibitions about women in Australian museums since 2017, it became clear that in order to more fully articulate colonial women's contributions to Australian historical memory, their language needs to be enlivened and physicality more accurately embodied. An appreciation of audience, and the sensory visitor experience is key to targeting all aspects of storytelling available in museums-particularly in communicating complex, often challenging, narratives. Some suggested methods of the reinterpretation of colonial women in Australian museums include the re-evaluation of language used to both describe and represent these women. Reconsidering traditional representations of the domestic as less valuable to contributions of public life, for example, can shift a masculine-focused narrative to one that considers the value of women's work on the frontier. Placing greater emphasis on the contribution of valuable domestic work, as well as highlighting the adaption of skills many women brought to the colonial experience can shift perceptions of women's contribution on the frontier. Similarly, reinterpreting objects previously regarded as masculine by applying revised language to encompass a more gender-diverse exhibition narrative is an effective (and budget-friendly) adjustment for museums-reinventing their collection through interpretation.

Imaginative designs and, arguably, creative budgeting are needed to transform the representation of female forms in museums and galleries. While it may take more effort, and a greater budget, to customise mannequin stock in order to more fully, and accurately, embody curatorial subjects, it is not always necessary in order to balance female representations 
in exhibitions. ${ }^{64}$ The inclusion of complementary interpretive materials can do this work to enliven the character of real-life women out of stock standard mannequin bodies, and place their words, their self-reflection, and their autonomy into the exhibition space. For example, where a masculine uniform immediately represents power and its enforcement, women's costume collections are rarely read in such a way. However, readjusting a colonial exhibition through the inclusion of a woman's costume piece, together with a reinterpretation of their role in 'civilising' the frontier through publishing their written work, representations of colonial power dynamics through art or broader audio-visual media, can more fully embody the original costume object and enliven the experience of this colonial woman to befit the curatorial subject. Museums should deliver these women's voices directly to the audience. This will enable those women to share with visitors their reflections, not only of their experiences of colonial life, but also the weight of their clothing, the heat of European layers under the Australian sun, and the blisters of uncomfortable footwear in sandy soil. The daily realities of womanhood in the environment of 'the other' cannot be communicated through the plastic bodies of a stagnant mannequin. These subtle shifts, from pose to curatorial focus, will enliven women, and their bodies, in our museums and galleries and, importantly, place their autonomy back into the colonial narrative and public memory. Only by more fully representing the diversity of our shared collective memory can we encourage widespread acceptance of a more diverse and inclusive collective identity.

64 A recent example of custom-made mannequins was in the Arts Centre Melbourne touring exhibition 'Kylie on Stage' (on display at the Western Australian Maritime Museum, 16 February - 9 June 2019). Displaying mannequins based on Kylie Minogue's body, to fit her performance costumes from the 1980s to 2015, they were posed as performers on stage, befitting the concert tour curatorial subject and adding to the enlivening of the costumes on display. 


\title{
The Mother Archive: Immersion, Affect and the Maternal in Museum Practice
}

Rebecca Louise Clarke

Monash University

\begin{abstract}
In a discussion of my digital archive project, 'The Mother Archive', I ask: what would a museum program about motherhood look and sound like? Identifying an absence of motherhood and the maternal as curatorial themes in Australian museums, I argue for a need to address maternal experience in museum practice. I then ask: how can digital technologies be used in museum settings to give us greater insight into maternal experiences? I suggest that the immersive technology of virtual reality (VR) could lead us to a deeper understanding of maternal subjectivity by enabling affective encounters. The immersive potential of VR has been used in areas including psychology (for instance trauma recovery) and workplace training. But its capacity to achieve affect in the context of museum environments has not been explored fully in scholarly work. While there is much conceptualising of VR as a tool of embodiment and empathy, there is no known scholarly work on how VR might enable us to engage with maternal subjectivity. My project strives to fill this gap in knowledge by creating a digital archive representing actual experiences of mothering as voiced by mothers.
\end{abstract}

How does a mother make sense of her maternal experiences? The wellknown What to Expect When You're Expecting, first published in 1984, now in its fifth edition, remains on the New York bestseller list. This book, along with countless websites targeted at expectant mothers, aims to educate women about each stage of their pregnancy. In this sense, there is little room for perspectives on 'matrescence', the transformation of first-time 
motherhood, outside the parameters of medical language. ${ }^{1}$ My project, 'The Mother Archive' strives to create a digital archive of 'inobservable worlds' the actual experiences of matrescence as voiced by mothers. ${ }^{2}$

'The Mother Archive' is an interdisciplinary $\mathrm{PhD}$ project based at Monash University. This project is informed by my curatorial research at Museums Victoria (MV) on their mother-related collection material, and my experiments with digital technologies to create an archive of maternal experiences, based at Monash University's SensiLab. The aim of this project is to design a digital, immersive archive of motherhood (and maternal experiences) using digital technologies (including, for instance, virtual reality (VR), immersive sound design, and motion capture technology), with the aim of articulating experiences of mothering. The immersive potential of VR has been used in areas including psychology (for instance, trauma recovery) and workplace training. But its capacity to achieve affect in the context of heritage environments has not been explored fully in scholarly work. While there is much conceptualising of VR as a tool of embodiment and empathy, there is no known critical attention to how VR might enable us to engage with maternal subjectivity. My research seeks to fill this gap in knowledge by imagining how VR might be used in the creation of a 'mother archive' to be displayed in museum settings. By experimenting with immersive technologies including VR, I seek representations that challenge dominant discourses on motherhood. My project aims to bring more visibility to the role mothers have played in Australian history by representing maternal experiences in museum settings.

In my practice-led research, I explore how immersive experiences might lead us to an embodied connection with maternal subjectivities. I suggest that various characteristics of maternal experience (for example, emotional

1 I would like to thank Professor Therese Davis, Dr Thomas Chandler, Dr Joanne Evans and Dr Vince Dziekan at Monash University for their thoughtful comments and encouragement. I would also like to thank Dr Carla Pascoe Leahy, at University of Melbourne, and MV Senior curator Deborah Tout Smith for generously offering me their time and expertise, and VR filmmaker Sojung Bahng for her valuable insights on VR cinema. I also acknowledge the support of the Australian Government Research Training Program Scholarship and the Robert Blackwood Museums Victoria - Monash University Partnership Award in the writing of this article. Dana Raphael, 'Matrescence, Becoming a Mother, a "New/Old” Rite De Passage', in Being Female: Reproduction, Power and Change, ed. Dana Raphael (Berlin: Walter de Gruyter, 1975), 65-71, doi.org/10.1515/9783110813128.65.

2 Anne E Sexton and Dolly Sen, 'More Voice, Less Ventriloquism: Exploring the Relational Dynamics in a Participatory Archive of Mental Health Recovery', International Journal of Heritage Studies, 24, no. 8, (2018): 847, doi.org/10.1080/13527258.2017.1339109. 
connections to one's child, and atmospheric sounds and images specific to the environment of mothering) are intangible in nature, and then go on to explore how techniques of digital immersion might enable us to better engage with intangible heritage (the intangible heritage of mothering might include, for instance, oral histories, soundscapes, religious and cultural rituals) and lead us into a more profound understanding of maternal experiences by enabling affective encounters. Drawing on my experiments, I analyse the ways that VR might enable us to challenge and disrupt dominant discourses on motherhood, discourses that commonly spring from realms of medical language, nostalgia and Western notions of the ideal mother. By making the subjective inner-worlds of mothers a primary concern in my work, my research offers contributions to the fields of maternal studies, museum studies and immersive technologies, including VR cinema.

This article asks: how can we represent the inner-world of mothers and 'maternal subjectivity' in museum collections and programs? First, I identify an absence of 'motherhood' and maternal experience as curatorial themes in Australian museum collections and programs. Drawing on my current curatorial research at MV in which I study mother-related collections, I identify gaps in MV's collection and programs and argue for a need to address maternal experience. I then ask: what would an exploration of the theme of motherhood in museums look and sound like? I propose that a collection on motherhood, or what I will call a 'mother archive', can best be facilitated by curatorial practice that employs techniques of immersion, affect and the model of the 'relational museum', and that digital technologies offer us valuable tools to realise these techniques. ${ }^{3}$ I then ask: how might VR help with conceptualising a 'mother archive'? I suggest that VR, with its potential for creating embodied understanding could contribute much value to exhibitions displaying mother-related content and could provide some of the valuable tools we need to come to a closer understanding of maternal subjectivity. In a discussion on my own experiments with VR, I explore the ways that VR might offer us representations of the maternal that challenge dominant discourses on motherhood and can lead us into a deeper understanding of the maternal experience by enabling affective encounters.

3 For more information see: Michael Alistair Jones, 'Documenting Artefacts and Archives in the Relational Museum' (PhD thesis, School of Historical and Philosophical Studies, University of Melbourne, December 2018). 
Perhaps at first glance, mothering could be considered just too quotidian for a museum collection or exhibition. A 'mother archive' might necessarily entail a focus on the banal and everyday, and consequently a resistance to grand narratives and monumentality, components considered central to notions of nationhood. Museum scholar Laurajane Smith critiques museums' privileging of grand narratives, and what Smith terms 'authorised heritage discourse', suggesting that heritage institutions value the monumental over the banal as a necessary upholding of national pride. ${ }^{4}$ Smith points out that often the events being 'remembered' by museums are dramatic in their significance and although negative events are preserved by museums, it is the exceptional that is favoured over the ordinary:

Even when it is the "bad" that is being preserved, it is very often the exceptionally "tragic" event that is being commemorated, rather than unpleasantness that is more mundane or reflective of the general inequalities of human experience. ${ }^{5}$

I argue that it is the 'stories of quiet heroism' that need more attention in Australian history and deserve to be represented. ${ }^{6}$ As maternal scholars such as Anne Manne, Petra Bueskens and Maria Tumarkin argue, the role of caregiver is under-valued and under-represented in contemporary Australian society. ${ }^{7}$ My project aims to bring more visibility to the role mothers have played in Australian history by representing maternal experiences in museum settings.

A survey of online museum catalogues reveals that rarely has motherhood been granted contemplation as a curatorial theme in museum collections and programs. The Victoria \& Albert (V\&A) Museum of Childhood in London holds childhood collections relevant to children and family, but there is no collection thematically concerned with motherhood. ${ }^{8}$ In the US, the Smithsonian recently ran the exhibition 'Picturing Motherhood' that displayed photography and paintings depicting representations of mothers in fine art. ${ }^{9}$ While this exhibition sheds light on the way motherhood has been represented throughout history, the inner-world of mothers, or maternal subjectivity, remains largely absent as a curatorial

4 Laurajane Smith, Uses of Heritage (Abingdon: Routledge: 2006), 23.

5 Ibid.

6 Anne Manne, 'Mothers and the Quest for Social Justice', in Dangerous Ideas About Mothers, eds. Camilla Nelson and Rachel Robertson (Perth: University of Western Australia Publishing, 2014), 23.

7 Ibid., 25; Petra Bueskens, 'Containing to Creating, Maternal Subjectivity', in ibid., 197-210; Maria Tumarkin, 'Against Motherhood Memoirs', in ibid., 86.

8 Museum of Childhood, Victoria and Albert Museum (V\&A), www.vam.ac.uk/moc.

9 'Picturing motherhood', Smithsonian, www.si.edu/spotlight/mothers-day. 
concern. The Museum of Motherhood (MOM), based in New York is a unique case as the only known museum devoted specifically to the theme of motherhood. ${ }^{10}$ Founded by adjunct professor of motherhood studies, Martha Joy Rose of Manhattan College, the museum houses a collection of objects ranging from the political (for example, activist pamphlets) to the personal (including personal testimonies authored by mother writers and artists) with an emphasis on public education and feminist activism. ${ }^{11}$ At a local level, as of yet there is no known Australian museum that focuses on motherhood (or maternal experience) as a curatorial theme. In Australian museum collections, the topic of motherhood is often raised in the peripheral, as a side note to other issues, which serve as the focus of collections such as women's movements, childhood and immigration. The representation of mothers in museum collections and programs is also a neglected area of interest in scholarly work.

In the following section, I focus my attention to mother-related collections at MV and argue for a need to explore experiences of mothering in museums collections and programs.

\section{Museums Victoria (MV): A Case Study}

Currently, MV's collection holds over 17 million items, including objects relating to Indigenous Australian and Pacific Islander cultures, geology, historical studies, palaeontology, technology and society, and zoology. ${ }^{12}$ MV was first established as the National Museum of Victoria in 1854, which had a primary focus on natural sciences. In 1870 , the Industrial and Technological Museum was established to research, collect and display scientific and technological advances. When the two institutions were brought together in 1983, social history was added as a further research and collecting area. In 2016, the museum was renamed Museums Victoria (MV) and now encompasses Melbourne Museum, Immigration Museum, Royal Exhibition building, Scienceworks, Bunjilaka and IMAX cinema. These sites, all residing in Melbourne, Victoria, are major tourist attractions and education sites for those visiting Melbourne. For instance, the Melbourne Museum in Carlton houses permanent exhibitions on the history of Melbourne and, more recently, Indigenous history, which

10 Museum of Motherhood (MOM), mommuseum.org.

11 Ibid.

12 'Collections', Museums Victoria, collections.museumsvictoria.com.au. 
attracts international visitors and school excursion groups. Currently, MV holds a collection of over 17 million items, held in storage facilities at Melbourne Museum, Scienceworks and a specialised storage facility.

The recent development of MV's Pauline Gandel children's gallery demonstrates MV's awareness that children visitors (both within school excursion groups and families) are vital to the survival of their museums. ${ }^{13}$ Over one third of all visitors to Melbourne Museum are families, and yet in exhibits, parents, carers and experiences of mothering are not specifically being addressed. In MV's Collection Plans 2013 - 2018, which summarises the aims and future directions of their collections, motherrelated collections include: Childhood, Migration and Cultural Diversity, Medicine and Health, and Home and Community. ${ }^{14}$ These categories have been formed thematically by curators and consist of material that can be found on MV's catalogue system EMu. Keywords and subjects recognised in the EMu system do not include 'mother' and 'maternal', but instead can be found indirectly through broader terms such as 'domestic life'.

MV have made efforts to include marginalised voices in their programs by curating collections and exhibits that engage with indigenous cultures, and seek out a counter-narrative to white colonial perspectives. For example, the Bunjilaka Aboriginal cultural centre at Melbourne Museum has a permanent exhibition on Indigenous cultures and MV's Immigration Museum has hosted programs addressing themes of cultural diversity and immigration histories. MV's recent exhibition 'WWI: Love and Sorrow', which commemorated the 100-year anniversary of WWI, paid substantial attention to the experiences of families of war (including mothers of war soldiers). ${ }^{15}$ These developments at MV show an enthusiasm to engage with the concerns of marginalised groups and a willingness to re-consider

13 Pauline Gandel children's gallery, museumsvictoria.com.au/melbournemuseum/whats-on/ childrens-gallery/. It cannot be confirmed exactly how many mothers visit MV, although this author has observed (as a mother and frequent visitor myself) the Melbourne museum is commonly frequented by mothers and their children. MV keeps records of their visitor statistics in their ticketing system, though details such as gender are not documented, which makes specific characteristics of visitors hard to decipher.

14 Carla English (ticketing records officer) interview with Rebecca Louise Clarke (Melbourne, 17 March 2020); Museums Victoria, Collection Plans 2013 - 2018 (Melbourne: Museums Victoria, July 2013).

15 For more information, see Deborah Tout-Smith, 'Love \& Sorrow: The Role of Emotion in Exhibition Development and Visitor Experience', in Emotion and the Researcher: Sites, Subjectivities, and Relationships, Studies in Qualitative Methodology, Vol. 1, eds. Tracey Loughran and Dawn Mannay (Bingley, United Kingdom: Emerald Publishing Limited, 2018), 159-76, doi.org/10.1108/ s1042-319220180000016011. 
what might constitute 'heritage' in innovative, museum practice. For instance, their recent exhibition 'Love' held at the Immigration Museum demonstrated an approach to curatorial practice that groups collection material into a broader theme of 'love' in all its varying definitions, without being anchored to a particular time period or geographical location. This demonstrates MV's growing interest in taking thematic approaches to their exhibit concepts. But maternal experience as a thematic focus has not yet been explored.

Recent projects have taken a look at motherhood in MV's collections. Melbourne historian and author Dr Carla Pascoe Leahy has undertaken a substantial body of work on the history of childhood, which has included archival research on MV's childhood collection. Pascoe Leahy is currently conducting oral histories from several generations of Australian mothers to analyse how understandings of 'selfhood, work, care, and gender have played out in the lives of mothers from 1946 to the present' ${ }^{16}$ These oral histories will be acquired by MV as part of their collection. MV curator Liza Dale-Hallett has played a pioneering role in the development of women-centred collections at MV. Dale-Hallett initiated The Invisible Farmers Project, a collection that focuses on women farmers (often wives and mothers) who have played crucial roles, often involving the 'invisible' labour (for instance, domestic labour and child rearing) important to farming life in Australia. Dale-Hallett's project, which still thrives with an active online MV blog, was created when Dale-Hallett put forward the strong argument that a collection is needed that acknowledges unpaid domestic labour and that rural women and mothers should have a vocal place in the history of Australia. Rural women's invisible labour has since had a place in MV's collection in the form of objects and oral histories. ${ }^{17}$ However, while written transcripts are available via EMu and snippets of interviews displayed on the Invisible Farmers project blog on the MV website, generally the museum visitor is unlikely to hear these voices.

The William Boyd Childhood Collection, housed in MV's Childhood Collection, is another collection that offers glimpses of maternal experiences. The collection consists of over 700 objects, including most of the childhood possessions of William (Bill) Boyd, encompassing

16 Carla Pascoe Leahy, 'The Experience of Becoming a Mother since 1945', Australian Research Council (DECRA) project, University of Melbourne, 2018.

17 Barbara Pini, Ruth Panelli, and Liza Dale-Hallett, 'The Victorian Women on Farms Gatherings: A Case Study of the Australian "Women in Agriculture" Movement', Australian Journal of Politics \& History, 53, no. 4 (2007): 569-80, doi.org/10.1111/j.1467-8497.2007.00475.x. 
toys, books, clothing and other items that Bill and his mother collected. The MV website describes the collection as demonstrating a range of prominent themes in the lives of postwar Victorian children, such as the ability to 'make do' under harsh circumstances and the changes in toy manufacturing (towards plastic materials and mass production), the prominence of gender roles, and the popularity of transport- and warthemed toys for boys. ${ }^{18}$ The collection was passed onto Bill after his mother's death and eventually donated to the Museum of Childhood at Edith Cowan University in Western Australia (when the Museum of Childhood closed it was transferred to the Museum Victoria in 2009). This collection, I suggest, also reveals the ways that Bill's mother, Lillian Boyd, archived her experiences of motherhood. The objects have been exhibited in contexts outside of motherhood specifically, to address national concerns. For instance, objects from the William Boyd collection have been displayed as part of exhibitions concerned with immigration histories and Melbourne history, and have an online presence on the MV blog in which their national significance is discussed. ${ }^{19}$

I suggest that if the mother-related collections that I have outlined were to be explored under the thematic umbrella of motherhood, a different set of concerns could then be addressed and much could be learned about experiences of maternal subjectivity. For instance, it would be interesting to know what these objects represented to Lillian Boyd personally and why she chose to order them in a certain way. If we consider the mother as archivist, in this light, it could also be considered that a mother's collected objects place her on display as a parent. In this sense, it would be worth examining whether the act of archiving involves a performance of motherhood in a self-conscious or idealised way, favouring nostalgia over challenging realities. What Lillian Boyd and her son kept reveals a lot about how clothes were made, how children were taken care of, and the available domestic technologies of the time. I suggest that what is missing from this collection are the more banal, everyday 'things' of matrescence, specifically the voice of the mother and access to her experiences of early motherhood in all its chaos and messiness.

I suggest that digital technologies could offer us intimate encounters with the intangible aspects of mothering. As digital humanities theorist and curator Sarah Kenderdine observes, digital technology offers valuable

18 'William Boyd Collection', Museums Victoria, collections.museumvictoria.com.au/articles/1622.

19 Ibid. 
tools to display intangible cultural heritage. ${ }^{20}$ Intangible heritage, which can include oral traditions, expressions and language, can be preserved or re-enacted with the assistance of technologies such as motion capture, VR and immersive storytelling. ${ }^{21}$ Intangible aspects of motherhood hold potent elements of maternal subjectivity and a 'mother archive' could articulate these aspects with the use of digital technology. In what follows, I outline a 'mother archive' that articulates experiences of motherhood as voiced by mothers.

\section{The Mother Archive: Theory}

The 'mother archive' is woven from oral histories, objects and images drawn from maternal experiences-my own and those close to me including, for instance, my mother, mother-in-law and aunt. Inspired by my own experience of becoming a mother for the first time, it is a deeply personal project, which does not seek to define any universal experience of mothering but rather to articulate aspects of complex and hard-todefine maternal subjectivities and to ask: how might digital technology afford us opportunities to experience aspects of maternal subjectivities in a museum setting?

In my role as curator, I employ a practice-led methodology to imagine what a 'mother archive' might look and sound like. Practice-led methodology allows me to illustrate theories with practical experiments relevant to the industry or practice-in this case, the industry of museums and the practice of curatorship, which my project seeks to illuminate. Practice-led research is 'concerned with the nature of practice' (in my case, curatorial practice) and leads to 'new knowledge that has operational significance for that practice. The main focus of the research is to advance knowledge about practice, or to advance knowledge within practice.' 22

\footnotetext{
20 For further information, see Sarah Kenderdine and Jeffrey Shaw, 'Archives in Motion', in Museum and Archive on the Move: Changing Cultural Institutions in the Digital Era, ed. Wendy Coones and Viola Rühse (Berlin: Walter de Gruyter GmbH \& Co KG, 2017), 211, doi.org/10.1515/9783110529630. 21 Intangible heritage has been defined as including: performing arts, social practices, rituals and festive events, knowledge, traditional craftsmanship. See Huib Schippers, 'Applied Ethnomusicology and Intangible Cultural Heritage', in The Oxford Handbook of Applied Ethnomusicology, eds. Svanibor Pettan and Jeff Todd Titon (Oxford: Oxford University Press, 2015), 134-56, doi.org/10.1093/ oxfordhb/9780199351701.013.7.

22 Linda Candy, 'Practice based research: A guide', CCS report 1 (2006): 1-19.
} 
My research draws on the approach employed by qualitative researchers (rather than by logical and statistical procedures) who 'use multiple systems of inquiry for the study of human phenomena including biography, case study, historical analysis, discourse analysis, ethnography, grounded theory and phenomenology'. ${ }^{23}$ My methodology is based on the assumptions that 'knowledge is subjective rather than objective' and that I learn from the participants in order to 'understand the meaning of their lives'. ${ }^{24}$

Given that my subjects of study include myself and those close to me, I use autoethnography, which seeks to analyse personal experience (auto) in order to understand cultural experience. It is value centred rather than pretending to be value free. As Carolyn Ellis, Tony E Adams and Arthur P Bochner describe it in the journal Forum: Qualitative Social Research:
When researchers write autoethnographies, they seek to produce aesthetic and evocative thick descriptions of personal and interpersonal experience. They accomplish this by first discerning patterns of cultural experience evidenced by field notes, interviews, and/or artefacts, and then describing these patterns using facets of storytelling (e.g., character and plot development), showing and telling, and alterations of authorial voice. Thus, the auto-ethnographer not only tries to make personal experience meaningful and cultural experience engaging, but also, by producing accessible texts, she or he may be able to reach wider and more diverse mass audiences that traditional research usually disregards, a move that can make personal and social change possible for more people. ${ }^{25}$

In order to explore the representation of maternal subjectivity in VR, I apply the following technology applications: I create a VR 360-degree video scene, I collect oral history recordings and atmospheric sound recordings, and I apply immersive soundscapes to the VR 360-degree environment. In my collection of VR works, I investigate maternal subjectivity through an exploration of the messy, banal, hard to articulate and hard to define everyday-ness of mothering. It is through this exploration that the normal and banal are made interesting, surprising and strange, allowing for a critique of assumptions we have in Australian society about motherhood,

23 Carolyn Ellis, Tony E Adams, Arthur P Bochner, 'Autoethnography: an Overview', Forum: Qualitative Social Research, 12, no. 1 (2011): 273-90.

24 Ibid.

25 Ibid. 
the cultural expectations placed on the 'mother' identity and a critique on archival practice that frames representations of (and produces knowledge about) motherhood.

\section{Maternal Subjectivity}

How can the complex experience of becoming a mother be defined? Medical anthropologist Dana Raphael coined the term 'matrescence' in 1975 to describe the experience of becoming a mother for the first time. ${ }^{26}$ Since then the term has been used by maternal scholars in their explorations of what it might mean to become a mother. I argue that, as leading Australian maternal scholars Petra Bueskens and Alison Stone suggest, maternal subjectivity needs to be thoroughly explored in order to free representations of motherhood from clichéd paradigms. ${ }^{27}$ Stone, drawing on psychoanalytic theory, argues that were cultural assumptions about motherhood to be changed, what is normally considered the 'natural fact' of mothering could be experienced differently and that maternal subjectivity could then be more easily understood. ${ }^{28}$ Interestingly, Stone suggests that maternal subjectivity would not be subjectivity-as-usual but rather specifically maternal: 'a specific form of subjectivity that is continuous with the maternal body, both the body of the one who mothers now and, in memory and fantasy, the one who mothered her, the mother's mother'. ${ }^{29}$

My exploration is most inspired by features of maternal subjectivity described by creative writer and historian Sarah Knott and maternal scholar and psychotherapist Lisa Baraitser. ${ }^{30}$ The characteristics Knott and Baraitser attribute to maternal subjectivity have informed my experiments because they have resonated most with my own experience of mothering. Knott's 2019 Mother: An Unconventional History was written when Knott became pregnant with her first child. Knott sought to make sense of her experience by seeking out the forgotten histories of motherhood from different communities as far back as the sixteenth century. Knott's creative narrative includes her anecdotes from her own life, which are intermingled

26 Raphael, 'Matrescence', 65-71.

27 Bueskens, 'Containing to Creating', 197.

28 Alison Stone, Feminism, Psychoanalysis, and Maternal Subjectivity (Abingdon: Routledge, 2013).

29 Ibid., 3.

30 Sarah Knott, Mother: An Unconventional History (London: Penguin, 2019); Lisa Baraitser, Maternal Encounters: The Ethics of Interruption (Abingdon: Routledge, 2008). 
and contrasted with those of other mothers throughout times and cultures. Knott describes this process: 'The telling of anecdotes, it is seeming to me, is a peculiarly powerful means of moving between history with a capital $\mathrm{H}$ $\ldots$ and the mundane stuff of living with an infant'. ${ }^{31}$ As a reviewer of Knott's book aptly describes:

The fragmentary nature of these anecdotes becomes an essential element of the book's fabric; Knott wants in part to capture the distracted, interrupted nature of new motherhood and often describes going about her research while trying to get her son to sleep or feed. ${ }^{32}$

In Baraitser's 2008 book, Maternal Encounters: The Ethics of Interruption, her view of the maternal state of mind is congruent with that of Knott's 'distracted, interrupted nature of new motherhood'. ${ }^{33}$ Baraitser seeks to present a major new theory of maternal subjectivity as well as discussing current understandings of contemporary motherhood in Western society. Baraitser's approach explores philosophies of feminist ethics, psychoanalysis and social theory. Like Knott, Baraitser cuts between her own anecdotes and theoretical concepts, reflecting the distracted, 'interrupted' characteristics of the maternal subjectivity described. Baraitser's 'ethics of interruption' goes beyond views of mothering as an interruption to an otherwise straight-forward inner life, but rather to articulate 'the potential within maternity for new experiences, sensations, moods, sensibilities, intensities, kinetics ... new coagulations of embodied and relational modes..$^{34}$

I argue that if matrescence is characterised by the messy, chaotic, interrupted and hard to define, as Knott and Baraitser describe, then the aesthetic techniques used to capture it would need to allow for the expression of these elements. I suggest that theories on immersion, affect and relation can lead us into a deeper understanding of the maternal experience by enabling affective encounters. In the following section, I give a brief overview of these concepts, which I suggest can shed light on the way the theme of motherhood could be explored in museum settings.

31 Knott, Mother, 5.

32 Stephanie Merritt, 'Mother: An Unconventional History - Review', Guardian, 10 March 2019, www.theguardian.com/books/2019/mar/10/mother-an-unconventional-history-childless-voicessarah-knott-lorna-gibb-review.

33 Ibid.

34 Baraitser, Maternal Encounters, 3. 


\section{Immersion, Affect and Relation}

Since Michel Foucault's 1969 The Archaeology of Knowledge, Foucault's theories of knowledge epistemes, power structures and regulatory spaces have been widely influential in scholarly work that highlights the power of the archivist to wield control over knowledge and the ordering of information. ${ }^{35}$ Museum scholars have written on the power that museums hold as history tellers. As museum scholars Fiona Cameron and Helena Robinson argue in their discussion of the documentation (or cataloguing) practices of museums, 'the act of description is not neutral'. ${ }^{36}$ They suggest that 'documentation is more than a repository of unadulterated "facts", rather, it constitutes an ideologically and culturally drenched form of text in its own right'. ${ }^{37}$ Characteristics such as date, medium and artist, while seemingly neutral, are not necessarily so. Museum scholar Laurajane Smith has written extensively about the power that museums wield as meaning-makers. In a critique of what Smith has termed 'authorised heritage discourse', Smith argues that heritage discourse works to reinforce national identity and mythology. In this model, the museum visitor plays a passive role and is not active in their relationship with museum content.

The theory of the 'relational museum', on the other hand, offers a new museology that emphasises museum's relationship with community. James Clifford's 1997 article 'Museums as Contact Zones' and Tony Bennett's 1998 Culture: A Reformer's Science point out that curators need to consider museums' roles as not just representers of communities but also as producers of knowledge and as institutions with various agendas. ${ }^{38}$ In the new museology, a curator is not a neutral preserver of history but is responsible for translating community histories for museum audiences. The relational museum is a suggested model in which the visitor is participatory in meaning making rather than being in a passive position as listener to an authorised heritage voice.

35 Michel Foucault, The Archaeology of Knowledge (London: Tavistock, 1972).

36 Fiona Cameron and Sarah Kenderdine, Theorizing Digital Cultural Heritage: A Critical Discourse (Cambridge: MIT Press, 2007), 240, doi.org/10.7146/mediekultur.v27i50.5244.

37 Ibid.

38 James Clifford, 'Museums as Contact Zones', in Routes, Travels and Translations in the Late 20th Century (New York: Harvard University Press, 1997); Tony Bennett, Culture: A Reformer's Science (California: Sage, 1998); For more information see Jones, 'Documenting Artefacts and Archives in the Relational Museum'. 
I suggest that digital tools could activate the relational museum model because they provide unique affordances to help us interact with heritage in an active way. VR in particular could hold the potential for museums to engage their visitors in a relational way. The relationship created between museum content and the visitor through VR could encourage multiple and fluid interpretations of museum collection material, beyond the information conveyed in the static museum object label, allowing the visitor to become an active participant in meaning-making. The concept of 'relation' is helpful in conceptualising the ways that a VR archive can benefit curatorial practice. Museum theorist Viv Golding suggests that the concept of relation offers much to feminist museum practice because it 'challenges essentialism - notions of purity, fixity and authority that echo in the traditional museum's masculine framing of knowledge in glass showcases. ${ }^{39}$ Relation requires being open to multiple meanings and interpretations of collection objects. Golding suggests this might mean curators reach out to artists or the general public to engage with collections in a way that allows them to contribute to the meanings of the object rather than this meaning being fixed. As Golding describes it, the imaginative realm of relation denotes a 'third space' of 'unsettledness, unhomeliness, rupture, as well as a new basis for cultural production'. ${ }^{40}$ As museum theorist Melissa Rachleff points out, museums are having to consider including visitor participation as part of their programs in order to stay relevant. The Rosenbach Museum and Library, for instance, was able to survive by opening its interpretative enterprise to artists in residence. The artists were encouraged to provide creative interpretations of the collection. Rachleff describes this: 'In effect this museum collection is being perpetually rediscovered, radically transformed and created anew by exposing itself to risks. ${ }^{31} \mathrm{VR}$ challenges the very idea of an 'authorised heritage discourse' by highlighting the process of interpretation. Australian curator and museum scholar Andrea Witcomb describes the multimedia exhibition in the context of the museum: 'This is a revolution which has revealed the process of making meaning in exhibitions, a process which previously was made to appear neutral through a focus on the conventional world of objects. ${ }^{32}$

39 Viv Golding, 'Museums, Poetics and Affect', Feminist Review, 104, no. 1 (2013): 80-99, doi. org/10.1057/fr.2013.2.

40 Ibid.

41 Cited in Elini Myrivili, 'Performativity, Interactivity, Virtuality and the Museum', Museology E-journal, 4 (2007).

42 Ibid., 35. 
The immersive and experiential potential of the virtual exhibit means that the knowledge transmitted to the visitor is embodied. Embodied learning is a way that the visitor can be engaged in a participatory relationship with the museum content. Digital humanities researcher and curator Sarah Kenderdine, who has authored a vast body of work concerned with digital museology, suggests that digital technologies have the capacity to produce an embodied experience of museum content and proposes the notion of 'embodied museography' as a way of thinking about these developments and immersive approaches. ${ }^{43} \mathrm{VR}$, which attains its power by captivating the viewer's attention to induce a sense of immersion and presence, can be a unique and ideal tool for exploration of subjectivity, as it places the viewer in someone else's lived reality. VR's power as a tool for embodiment and empathy has been addressed in scholarly research, but its capacity to reinvent the archive has not yet been investigated.

Thinking about the way 'affect' works in museums is also helpful for this discussion. More recently, 'an affective turn' in museum practice has focused on understanding better how museums make us feel. ${ }^{44}$ For example, a 2015 special issue of the Journal of Curatorial Studies focused on the role of affect in exhibition design. ${ }^{45} \mathrm{I}$ draw on discourse analysis academic Margaret Wetherell's definition of affect as 'embodied meaningmaking' as a definition that is useful in the context of the museum and the way content is exhibited to create affective encounters for the visitor. ${ }^{46}$

Witcomb and co-author Australian curator Kate Gregory have written extensively on affect in the museum, and suggest that affect can help achieve 'embodied learning' for the museum visitor. Witcomb and Gregory argue that exhibits hold the capacity to 'produce a different kind of knowledgeone that embodies in a very material way, shared experiences, empathy, and memory'. ${ }^{47}$ The observations made by Witcomb and Gregory reflect the ways digital technology could engage visitors as active participants in the heritage experience, in a relational museum model. It could be argued that the only real way to understand matrescence is to immerse

43 See Cameron and Kenderdine, Theorizing Digital; Sarah Kenderdine, 'Embodied Museography', About the Culture Academy Singapore, 23 (2012): 27.

44 Jenny Kidd, “Immersive" Heritage Encounters', The Museum Review, 3, no. 1 (2018): n.p.

45 Jennifer Fisher and Helena Reckitt, 'Introduction: Museums and Affect', Journal of Curatorial Studies, 4, no: 3 (2015): 361-2, doi.org/10.1386/jcs.4.3.361_2.

46 Margaret Wetherell, Affect and Emotion: A New Social Science Understanding (London: Sage, 2012), 4 .

47 Kate Gregory and Andrea Witcomb, 'Beyond Nostalgia: The Role of Affect in Generating Historical Understanding at Heritage Sites', Museum Revolutions: How Museums Change and are Changed (2007): 47. 
ourselves in a mother's experience. While cinema offers us a glimpse of the maternal, VR could take this immersion a step further, engaging us with the inner world of mothers and experiences of mothering.

In exploring the term 'immersive', I have drawn on museum theorist Jenny Kidd's analysis of the recent 'immersive turn' within museum contexts, in which Kidd suggests that immersive heritage practice has a number of key defining characteristics: 'it is story-led, audience and participation centred, multimodal, multisensory and attuned to its environment'. ${ }^{48}$ My analysis recalls the definition of immersion theatre theorist Nandita Dinesh who defines immersive as encounters that are 'multisensorial' and that privilege a 'participatory aesthetic'. ${ }^{49}$

While the terms 'immersive' and 'virtual' are trending in heritage publicity for MV programs, VR has only recently become a part of MV's content and so has not been fully explored in this heritage setting. ${ }^{50}$ In a broader sense, scholarly work on the use of VR in heritage settings is scarce. I begin my exploration in VR with a brief outline of its technology.

VR cinema is filmed on a static camera that can record in 360-degrees. This allows the viewer unlimited perspectives. The viewer wears a headset to watch the VR experience and is able to rotate and look at the complete 360-degrees, including along the vertical axis. VR has gained a reputation as an 'empathy machine', a phrase attributed to Chris Milk, founder of media company Within, known for the 2015 VR film Clouds Over Sidra (a collaboration with the United Nations and Samsung that takes users on a tour through Jordan's Za'atari camp for Syrian refugees). ${ }^{51}$ David Darg, cofounder of interactive-media agency Ryot, describes VR as 'the ultimate fundraising tool' because it can 'can create empathy like never before'. ${ }^{52}$

\section{Kidd, 'Immersive'.}

49 Cited in ibid.

50 For example, the MV website includes a 'Virtual Museum' online. Referring to MV's dinosaur display, the website's promotion states: 'Use this website to explore facts about the 17 skeletons of prehistoric animals on display in the exhibition.' The permanent exhibition at the Melbourne Museum is described as immersive: 'Touchable objects, immersive experiences and multimedia exhibits allow students to explore how these prehistoric animals moved, ate and survived in their changing environments.' This website is designed to be used as a teaching resource before and after a school excursions to the exhibition. In this instance, 'virtual' is used to refer to an online presence of aspects of the exhibition including text (written information about the dinosaurs) and images. For more information see 'Dinosaur Walk', Museums Victoria, museumsvictoria.com.au/melbournemuseum/resources/dinosaur-walk/.

51 Clouds Over Sidra, directed by Gabo Arora and Barry Pousman, 2015; Shamus Smith, Tim Marsh, David Duke, Peter Wright (1998) and Marie-Laure Ryan (2001) discuss VR's power as a tool for embodiment and empathy, cited in Elvia Wilk, 'Trauma machine: rewiring empathy with virtual reality', Western, 9 July 2018, popula.com/2018/07/09/virtual-reality-empathy-trauma/.2018.

52 Ibid. 
Several VR films demonstrate VR cinema's capacity to explore subjectivity, memory and trauma in the context of heritage; for example, Parragirls Past, Present unlocks memories of institutional 'care' drawing from oral histories of previous residents. ${ }^{53}$ Created by women who once lived at the institution Parramatta Girls Home, it is a deeply moving immersive VR film, which contains a 3D re-imagining of the institution site based on former residents' memories of the home. In this VR film, we see buildings of the institution, which have been drawn from former resident's memories, as we hear their recollections told in voice-over. This brings us in an intimate engagement with the memories of the residents. Chileanborn Australian VR artist Oscar Raby's VR work also offers an embodied experience of the intense trauma of war in an interactive virtual reality documentary Assent, which uses dream logic and video game aesthetics to depict the aftershocks of war. ${ }^{54}$ South Korean VR filmmaker Sojung Bahng's 2017 Floating Walk: Gangnam Kangaroo also brings the viewer into empathic engagement through Bahng's poetic voice-over narration and a 360-degree landscape that stiches together locales in South Korea (the filmmaker's home) and Australia (where the filmmaker currently lives) to recreate the inner-world of an international resident living and working in Australia, reconciling ancestral history and cultural identity. ${ }^{55}$ In this film we are able to experience the strange feeling of existing in two locales at once, coming into an empathic engagement with the unsettled emotions of immigration. As these examples illustrate, VR offers unique tools for empathic engagement, a feeling of presence, of having 'been there' at the site of the event or memory. It is these attributes that make it a technology worthy of contemplation in the cultural heritage field.

VR also offers a relational museum model with its capacity to present the visitor with an interactive archive. Through various software, from the more accessible and easy to use 'Wonda VR', to the more complex and multi-layered 'Unity', various levels of interaction between the viewer wearing the headset and the museum objects being displayed on the screen become possible. For instance, the viewer is able to navigate a menu of objects and by using the controls on the headset and can manually select which object they would like to learn about. Through gaze control, the

53 Parragirls Past, Present, writer/narrator Bonney Djuric, directed by The Parragirls Project, www.pffp memory.org.au.

54 Assent, directed by Oscar Raby, oscarraby.net/assent/.

55 Floating Walk, Gangnam Kangaroo, directed by Sojung Bahng, sojungb.com/floating-walkgangnam-kangaroo/. 
viewer only needs to merely look at an object on the screen to find out more about it or to even activate a new development in the narrative. In this way, 'relation' can be achieved in an active relationship between participant and museum content. Objects then become filled with meaning personal to the viewer, as they are able to come into an intimate engagement with them. In my VR experiment with everyday objects of mothering, VR has enabled me to imbue objects with affect.

In my 'mother archive' I have explored various ways to illuminate experiences of motherhood, and have investigated how VR experiences might enact embodied museography in museum practice.

\section{The Mother Archive-Practice}

As part of the process of creating the 'mother archive', I draw on the affective potential of sound by audio-recording everyday experiences with my daughter. My project experiments with teaming voice and material culture to create a relationship between material objects and digital sounds. In my attempt to articulate my own feelings about mothering, I have found, as Sarah Knott discovered in her research for book Mother: An Unconventional History, it is the banal sights and sounds that best demonstrate the realities of my experiences. ${ }^{56}$ I suggest then that the representation of the maternal in museum programs should involve an immersion in the daily realities of mothering and that a mother archive would need to contain collection objects pertaining to everyday realities.

\section{'Glow-face': Affect and Everyday Objects}

In my experiments with creating a digital archive of motherhood, I have reflected on the objects of matrescence that hold the most potence for me. One of these is our night-light.

It is this everyday object that I find captivating as it holds within it the emotions I felt in early parenting. A hallmark of early parenting for me was night-time. In many ways, it felt like this was when the work began. My daughter slept in the day but at night she woke, endlessly it seemed, for milk. It was in the half dark that we got to know each other;

56 Knott, Mother, 5. 
when she gave me her first smile, when she saw me. We called it 'glowface' because we didn't know what is was. Two-parts: unicorn and dog, it glowed, guiding us from room to room, from couch to breast to bed and back to couch again. In my VR work, I have brought glow-face to life. It moves and rotates around the dark 360-degree space that surrounds us so that we are able to feel it animated. Emanating a dull ever-switching colour, 'glow-face' - a name reflective of our inability to articulate in the trenches of sleep-wake caring - has its own personality, its own aura. We hear the rituals of night-time parenting on the soundtrack: a lullaby is half-sung, a baby monitor gurgles, the sound of breath pulses in the dark.

As Knott reminds us, night-time mothering is one of the key aspects of mothering that has been neglected in history:

In bed so many hours of each twenty-four, and wake for so many of those hours, I suspect that the middle of the night is maternity's most concealed past. Hard to fathom, yet perhaps most important to a person mothering. ${ }^{57}$

To display a simple night-light without personal context would not activate affect in a museum setting. In order to convey the object's personal significance and the object's affect, the curator would need to somehow bring the object to life-to animate it and to enable the visitor to feel connected to it, if not through physical touch, then through a sense of intimacy with the object. In my VR experiment, VR allows me to create this sense of intimacy. Hearing sounds associated with nighttime rituals also enables affective encounters with this everyday object and the lost history of night-time mothering. The intimate encounters with everyday objects afforded by VR technology resist grand narratives described by Laurajane Smith as hallmarks of authorised heritage discourse and instead work in a relational museum model and enables affective encounters. 


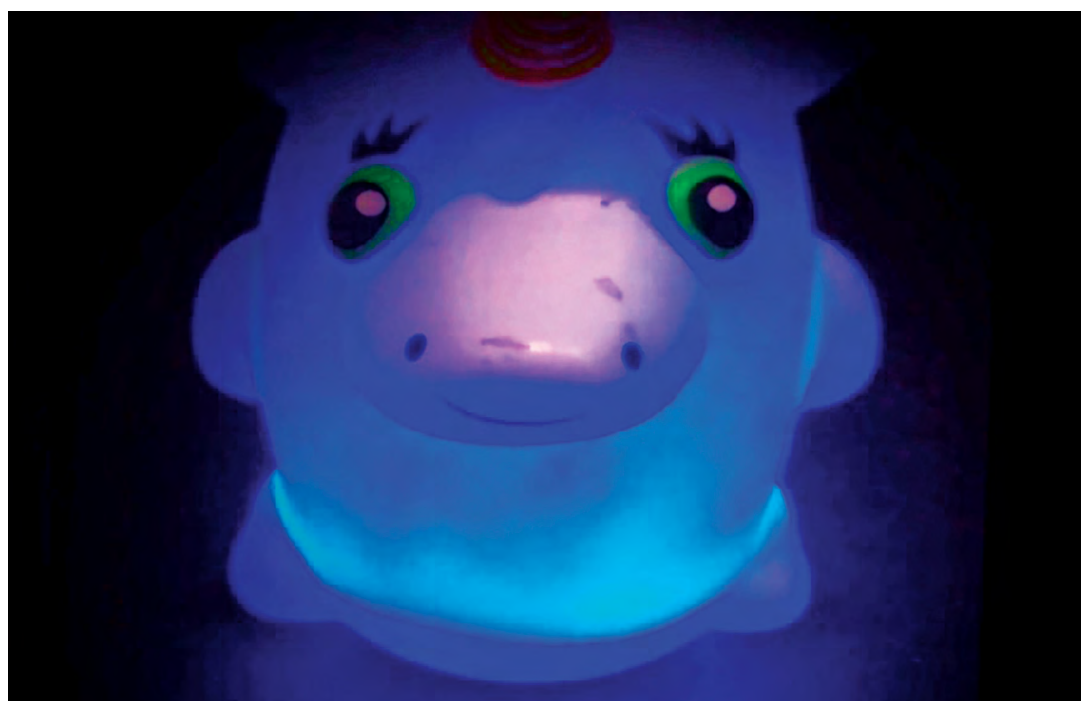

Figure 1: Glow Face.

Source: Rebecca Louise Clarke.

\section{Timelessness and Immersion}

When I audio-recorded my daughter over the course of a day it was in an attempt to see if I could capture a day in the life of my mothering. What resulted was an eerie sense of time becoming a loop, each activity and its sound repeated to the point that every day, every hour becomes indistinguishable from the next. Knott describes timelessness as being an important component of maternal subjectivity: 'There's just one long, blurry present, counted out in the days of the baby's age. Or maybe my days since the birth', writes Knott, of her own mothering. ${ }^{58}$ In a bright 360-degree daylight scene of a backyard, we see my daughter running. We hear the sounds over the course of a typical day of parenting, each sound growing more warped and repetitive. My toddler runs in circles around us. Her Dad is chasing her in a game she calls 'tiger'. The game is happening now, in the past, in the future, as they run around the circular landscape over and over. It could be one game or several, over the course of a day, or a week. Dad growls (he is tiger) and she screams, laughs, screams, laughs. When I watch this scene, I feel a sense of anxiety which I did not create intentionally but which has emerged regardless, an everpresent threat of things going sour, the feeling of 'it'll end in tears' as my 
mother used to say. It doesn't 'end in tears' but instead cycles, in a loop, through tears, laughter, screams, tired cranky pleas, and returns again to a game of 'one more' tiger.

While the voice is an area of museum studies not fully explored, in the context of radio, it has been given more attention. In a discussion of oral history narratives in radio programs, journalist Siobhan A McHugh offers insights into the relationship between orality, aurality, and affect:

An affecting testimony will ... arouse strong feelings in the listener, which will, in turn, influence how the listener processes the story and evaluates its meaning (cognition). Put simply, the affective power of sound and voice, combined with the intimacy of the listening process, means we can be moved by listening to oral history; this, in turn, affects how we absorb and retain its content, as well as how we judge that content. ${ }^{59}$

My VR scene brings the viewer into an everyday scene of motherhood. It does this not through a linear narrative or through narratives of nationhood or monumental moments in history. Rather, these scenes linger in moments of timelessness and chaos, resisting finality. In this way, my experiments with the technology work in the poetics of relation, and enable affective encounters through VR immersion. Through the presence that VR offers, the distance between subject (viewer) and object (what we see on screen) is brought into intimacy. Instead of the viewer merely observing the scene, the viewer in the 360-degree sphere is able to look around the backyard and feel that they are in the scene.

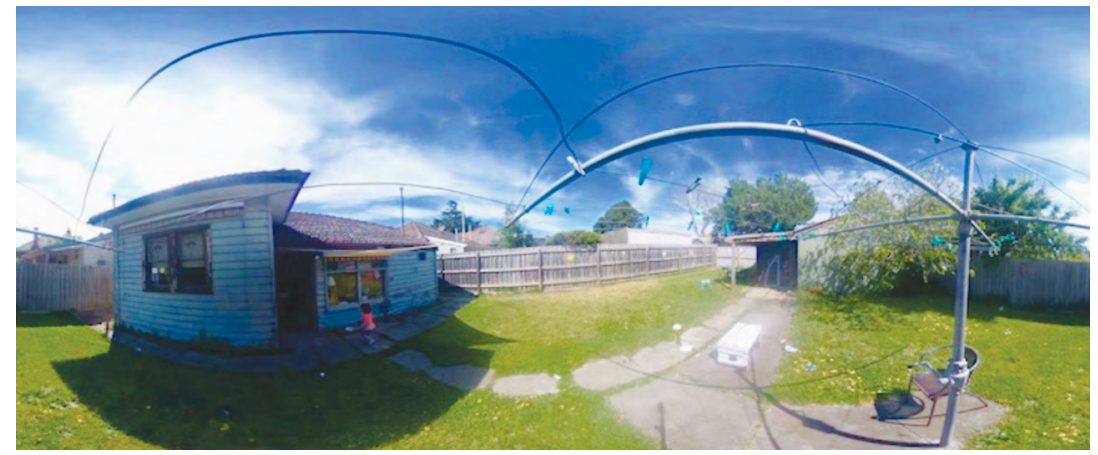

Figure 2: My daughter playing 'tiger'.

Source: Rebecca Louise Clarke.

59 Mia Lindgren and Siobhan A McHugh, 'Not dead yet: Emerging Trends in Radio Documentary Forms in Australia and the US', Australian Journalism Review, 35, no. 2 (2013): 101. 
In these instances, VR has enabled me to create representation of an 'interrupted', chaotic and repetitive state of mind typical of my day-today life as a mother, of what it is like to live a moment in my life as a Mum. Witcomb argues that exhibits hold the capacity to 'produce a different kind of knowledge-one that embodies in a very material way, shared experiences, empathy, and memory ${ }^{60} \mathrm{VR}$, with its potential to create immersion, can offer the 'physical expressions and material effects' that Witcomb describes of immersive exhibits. ${ }^{61}$ It also offers us intimate encounters with collection objects and the potential to become a part of the archive, to interact with it and to navigate it ourselves, activating affect and the poetics of relation. This approach to museum practice works to resist the grand narratives described by Smith as being hallmarks of authorised heritage discourse, and instead seeks to find those spots in maternal histories reminiscent of those found by Knott in her discovery of histories of mothering, those that linger 'between history with a capital $\mathrm{H}$ $\ldots$ and the mundane stuff of living with an infant'. ${ }^{62}$

\section{Conclusion}

In this article I have asked: how can we represent the inner-world of mothers and 'maternal subjectivity' in museums? Providing an analysis of MV's mother-related material culture, I observe an absence of motherhood as a thematic focus in museums. I then go on to explore how museums might best represent complex features of maternal experiences. I have suggested that the model of the relational museum, affect and techniques of immersion, in particular VR, offer valuable tools for museums to engage with the subject of mothering in innovative ways, which can work outside stereotypical narratives about motherhood.

VR's power to achieve embodiment and empathy has been addressed in scholarly research, but its capacity to reinvent the archive has not yet been investigated. My immersive archive aims to achieve a more expansive representation of maternal subjectivity by exploring what becomes possible when we approach the archive in new and exciting ways. I explore the potentiality of affect and empathy in museum practice, arguing that

60 Andrea Witcomb, The Materiality of Virtual Technologies: A New Approach to Thinking About the Impact of Multimedia in Museums (MIT Press, 2007), 47.

61 Ibid.

62 Knott, Mother. 
exhibitions that re-imagine and reframe collections have the unique capacity to create embodied and empathic responses. This engagement with the empathic and affect has pedagogic potential to enable younger generations to engage with histories of the past. Empathic response can be achieved by engaging with collection material in an embodied way.

Beyond the scope of this article, but in need of further analysis is the role of language and description in the archiving process, and how these would need to be re-considered in an imagining of an archive about motherhood. In the conception of the creative archive, new innovative ways to search for material can co-exist with more conventional forms of searching. The ontology that underpins the values of MV would need to be explored. Innovative approaches to archival language could make room for a collection that addresses individual experiences of mothering. Inspired by personal stories of participants responding to the subject of motherhood and my own personal experiences as a mother, my immersive archive explores the potential of affect in its representation of artefacts. I suggest that immersive exhibitions challenge the very idea of an 'authorised heritage discourse' by highlighting the process of interpretation. At the heart of my imagined collection, articulated in sound and image, is my exploration of affect, immersion and the messy, hard to define and neglected field of maternal experience. 



\title{
Women's Politics as Radical Politics: Reconceptualising Women's Historical and Contemporary Political Practices with the Work of Luce Irigaray
}

\author{
Belinda Eslick
}

University of Queensland

\begin{abstract}
In her paper 'Feminist History as National History: Writing the Political History of Women', Australian feminist historian Marilyn Lake urged scholars to create new narratives about women's political histories. Lake's subsequent work has informed approaches to feminist histories that challenge liberal feminist values and adherence to the narrative of the 'waves' of feminism by drawing scholars' attention to women's political histories outside of political institutions and parties. Lake argued that 'masculinist historiographical and conceptual frameworks' had rendered women's political histories invisible, and she called on scholars to develop new conceptual frameworks for understanding women's diverse, and mostly non-institutional, political theories and practices. Such new frameworks, Lake argued, could allow us to challenge the idea that women's political history had been one of 'failure'. As a non-historian engaging with Lake's work, I also see the value in developing such frameworks for understanding women's continuing non-institutional political activity in contemporary Australia. In this paper, I bring Lake's discussions of nineteenth- and twentieth-century Australian feminist political theories and practices together with French feminist philosopher Luce Irigaray's writing on politics. I explore how considering Irigaray's work could allow us to acknowledge women's political activities in ways that not only render them visible but also identify their potential radicalness.
\end{abstract}


It is common for women and women's influence to be missing from recorded political histories and national mythologies, including in Australia. And where there is a positive account of a 'great' or influential woman in political histories (in dominant as well as some feminist histories) it is commonly to document or tell the story of a female 'first'. For example, in Australia, we celebrate the first women to have run for election to government or become Members of Parliament, the first women who were allowed to vote, the first female state premier or prime minister, and so on. Women barely featured at all in Australia's political history before activists, feminist historians and other feminist scholars intervened-particularly from the 1970s. But, in dominant histories and contemporary public discourse, there has been and remains a tendency to fixate on those exceptional women who were or are able to break into (or lean into-as some recent liberal feminist attitudes encourage women to do) typically male realms, roles or occupations. This aspect of a woman's story is also likely to receive a dominating focus, even if a woman lived an active and influential political life before or after her entrance into institutional, 'formal', male-dominated politics. This is still arguably so in contemporary Australian public discourse and national mythologies: women are lauded for breaking through barriers but typically little else, and the women who have breached the 'frontiers' of men's worlds are celebrated.

It is less common to hear stories about women who have been influential from the places where women do already commonly dwell or have conventionally dwelt. These include, most notably, 'informal' or noninstitutional sites as well as the realms of society that are closest to the home. The scarcity or invisibility of women in recorded political histories and dominant cultural political narratives is—as some feminist historians have shown-no indication of women's idleness and not only because women have been lowly regarded in Australian society and by non-feminist historians. Rather, it is largely because of the promotion of particular ideals that have typically privileged men's stories and experiences and either explicitly or implicitly silenced (through excluding or devaluing) women's stories and experiences. The privileging of certain ideals or places in society means that women only become visible, or worth mentioning, when we reach a particular (male) standard. This means that much of women's activity—despite its significant influence—goes unacknowledged and unvalued. 
Some feminist historians in Australia, like the authors of Creating a Nation, showed that, in this sense, women were missing from dominant histories by default. ${ }^{1}$ This was because Australian histories typically privileged masculine ideals, endeavours and realms of society (that is, primarily government and the state, the military and war, and the frontiers of colonial development) and women have been mostly absent from or silenced in those realms. Women were not absent from dominant political histories because we had been politically idle but because women had been politically active outside of the most culturally privileged, male-dominated realms of society. One of the authors of Creating a Nation, Marilyn Lake, argued further with her 1996 article 'Feminist History as National History: Writing the Political History of Women' that privileging masculine realms of society and ignoring (and thereby devaluing) the sites where women act, perpetuated what she called the 'women-as-political-failures thesis'. ${ }^{2}$ Lake argued, in other words, that women's history was typically framed only according to women's apparent failure to achieve the political positions that men had. Lake argued that women were characterised as political failures despite women's energetic, engaged and influential political activity in different realms of society, and through different modes of 'doing' politics. The political practices that many women developed throughout the late nineteenth and twentieth centuries-and which continue into the twenty-first century-were, as Lake has helped to demonstrate, largely non-institutional and non-party.

With her subsequent work, particularly in Getting Equal: The History of Australian Feminism (1999), Lake documented some examples of women's non-institutional political activity in Australia. She argued, further, that these examples suggested that feminism in Australia had indeed 'flourished in the interwar years, decades that, in many ways, could be characterised as the golden age of the woman citizen. ${ }^{3}$ Such an interpretation, as Lake noted, was counter to the popular characterisation of this period by other feminist scholars as a disappointment because it had been marked by a relative lack of women in positions of institutional political power. Lake argued that to understand women's political histories more fully (and not as a history characterised by failure), scholars needed to look

1 Patricia Grimshaw, Marilyn Lake, Anne McGrath and Marian Quartly, Creating a Nation (Melbourne: McPhee Gribble/Penguin Books Australia, 1994).

2 Marilyn Lake, 'Feminist History as National History: Writing the Political History of Women', Australian Historical Studies, 27, no. 106, (1996): 154-69, doi.org/10.1080/10314619608596005.

3 Marilyn Lake, Getting Equal: The History of Australian Feminism (Sydney: Allen \& Unwin, 1999), 9. 
beyond masculine realms of society. She also argued that scholars needed to develop and apply new conceptual frameworks that would allow us to think differently about politics and about women's varied experiences as citizens in Australia.

As an academic in feminist theory and gender studies (that is, a nonhistorian) considering women's political practices in contemporary Australia, I have found Lake's work to be immensely beneficial for challenging perceptions about women's political engagement. Public discourse and political science surveys continue to measure women's political engagement according to a particular, masculine standardand the 'women-as-political-failures thesis' that Lake described persists, I argue, in contemporary Australia. ${ }^{4}$ With this paper, I consider Lake's call to 'develop new conceptual, analytical frameworks that will allow us to see more clearly the complexity of women's political history'. I respond by exploring how such feminist frameworks might be developed by engaging with French feminist philosopher Luce Irigaray-particularly her early feminist writing on politics and her philosophical contributions to rethinking women's subjectivities. Doing so can, as I argue, contribute new feminist resources for understanding women's political histories as well as contemporary experiences of politics.

Irigaray began publishing feminist work in the 1970s with her first feminist text Speculum of the Other Woman (published in French in 1974 and translated into English in 1985). Her work (along with other feminist scholars and writers in France at this time, like Hélène Cixous and Julia Kristeva) has made an enormous impact on feminist thought in the West. This has, notably, been through contributing to what have been considered as 'difference' feminisms, through her thinking on sexual difference, her rethinking of the categories of 'subject' and 'other' in response to the work of Simone de Beauvoir, and her critiques of egalitarian feminist perspectives. I will suggest with this paper that considering Irigaray's work in the context of women's non-institutional political practices-together with Lake's historical work-could allow us to acknowledge women's political activities in ways that not only render them visible but also identify their potential radicalness. I suggest that it is possible to show how women's distinct modes of doing politics can be reconceptualised

4 Lake, 'Feminist History as National History', 158.

5 Ibid., 161. 
as disruptions to the normativity of the masculine political subject and to phallocentric notions of citizenship, and not merely as ways of 'making do' with a lack of masculine political power.

I discuss Irigaray's feminist and philosophical (and feminist philosophical) perspectives and, specifically, her early work on women's relationships to politics. This includes her argument, put forth initially in This Sex Which is Not One (1977/1985), that women should develop new modes of doing politics that would not emulate existing, masculine political practices. I then consider how these perspectives can be thought with Lake's feminist historical work to develop critical feminist approaches to understanding women's political activities. Further, I also consider Irigaray's more recent work on politics, where she advocates for a politics, generally, based in relationality, care and with a greater attention to life and 'natural' rhythms. Finally, I begin to explore how this work might enable ways of reconceptualising the aspects of women's non-institutional political activity that have been conventionally considered to be the greatest barriers to women's 'legitimate' citizenship. This includes, for example, women's proximity to the home, local community and so-called 'private' realms of society. I question whether consideration of an Irigarayan ethic of politics could, in some ways, allow us to conceptualise these aspects of women's politics as signs of a radical rather than deficient politics.

\section{Looking to Where Women Actually Were: The Impacts of 'Difference' Feminisms}

Lake argued that the omission of women's non-institutional sites of political action from recognition in cultural and historical narratives had contributed to the presumption that women's political history had been one of 'woeful disappointment'. 6 This was coupled with criticism from feminist activists and scholars in the 1970s and 1980s who, Lake said, had suggested women in Australia had 'wasted the vote' by failing to enter parliamentary positions in high numbers in the twentieth century. Lake argued that we therefore needed a new approach to telling women's political histories - one that would acknowledge the distinct modes of politics that women employed outside of institutions-in order to counter the limited narrative of women's political 'failure'.

6 Lake, 'Feminist History as National History', 159.

7 Ibid. 
Lake's book Getting Equal: The History of Australian Feminism (1999) was itself a contribution to the new narrative that she advocated. It documented the vast and rich political contributions and influence from mostly white women in colonised Australia in the nineteenth and twentieth centuries. Many of the women documented in Lake's work practised what she has since described as a kind of 'white maternalist' politics outside of institutional politics-in clubs and societies, homes and public halls, and in sites of grassroots activism. ${ }^{8}$ Lake argued, for example, that 'contrary to the popular idea that the women's movement languished with the achievement of the vote', feminism in Australia had indeed 'flourished in the interwar years, decades that, in many ways, could be characterised as the golden age of the woman citizen'. ' Lake characterised this period as an immensely productive time of women's political advocacy and organising in Australia, where many women (particularly socially privileged women) lobbied for a broad range of social and political change. Further, many women had developed, as Lake found, 'their own mode of doing politics, eschewing for the most part the traditional male-dominated political parties in favour of mobilising women at the grassroots level'. ${ }^{10}$ Importantly, Lake was suggesting that women had been developing distinct ways of practising politics and were actively critiquing the status quo of parties and parliaments, describing women as 'leading theorists and practitioners of citizenship'. ${ }^{11}$

This influence, however, had not been documented or celebrated in recorded histories, as Lake argued in Getting Equal, writing:

That women were leading theorists and practitioners of citizenship, that they were outspoken advocates for proportional representation, a welfare state, Aboriginal citizenship, the custody rights of Aboriginal and non-Aboriginal mothers and the importance of international law seemed to be of no consequence to the men who document, and still document, our political history. It was as if political women had never existed. ${ }^{12}$

8 Marilyn Lake, 'Subjective Femininities and Feminist Subject Positions: White Maternalism and the Will to Power', Paper presented at 'Feminisms and Feminities', Lilith: A Feminist History Journal Symposium, Melbourne, November 2019.

9 Lake, Getting Equal, 9.

10 Ibid., 13.

11 Ibid., 6.

12 Ibid. 
Lake compelled us to counter the popular characterisation of women's political history as one of failure by telling feminist history as national history. This would involve going beyond a strategy of inserting women into an existing set of ideals or narratives_about nation-building, society or politics-and would instead involve radically reviewing the kinds of stories that we record, retell and canonise through radically rethinking what we deem politically, culturally and historically significant. Such an approach expands beyond a strategy of searching for traces of women in men's places, as Lake suggested previous scholars had largely done. Instead, it would aim to acknowledge, tell and retell new kinds of narratives that recognise women's distinct perspectives and experienceswhether as workers, mothers, teachers, farmers, writers, community leaders, grandmothers, business owners, artists, and so on. Doing so could acknowledge women's experiences as inherently valuable and significant, rather than only valuable according to their proximity to male-dominated institutions. In other words, the radical aspect of Lake's call was that women's histories should be acknowledged and valued according to what women were already doing or where we already were-an important feminist conceptual shift.

Lake also showed the limitations of conventional political science approaches to documenting women's political histories. She critiqued what she described as the 'reduction of the history of politics to parties and parliaments' and urged scholars to move beyond 'a Whiggish tale of women's entry into parliament and the counting of female politicians. ${ }^{13}$ To tell women's histories accurately and meaningfully, it was necessary to look beyond parties and parliaments. She suggested, for example, that empirical studies on women's participation with institutional politics were limited, writing:

Whereas political science models of investigation have provided valuable empirical studies of women's integration into parliaments and parties ... we also need to develop new conceptual, analytical frameworks that will allow us to see more clearly the complexity of women's political history and the vital interrelationship of public and private life. ${ }^{14}$

13 Lake, 'Feminist History as National History', 160.

14 Ibid., 161. 
Such new conceptual frameworks would, Lake argued, enable us to recognise 'citizen politicians', including Rose Scott, Jean Daley, Edith Jones, Bessie Rischbieth, Cecilia Downing, Mary Montgomery Bennett and Jessie Street, 'as key figures in Australian political history'. ${ }^{15}$ It would also allow us, Lake said, 'to see women's political history as a history of creativity and accomplishment'. ${ }^{16}$

Accounts of women who have been historically influential from typically feminine realms of society are rare for many reasons. The places where women have typically acted from are, first, not culturally valued in the ways that masculine sites (including institutional, state, industrial, commercial or military ones) are. But the sites of women's non-institutional political activity (including non-institutional, non-commercial, non-industrial places like the home and other 'private' spaces, women-only places or organisations, the local community, and grassroots sites of activism) are also often characterised by women's oppression. Many feminist scholars and activists are therefore wary of valorising these sites of women's political activity as this might risk appearing to justify women's social and political subordination or falling into essentialist claims about women's social roles. Any attempts to valorise women's experiences outside of male-dominated, privileged realms of society must therefore be approached critically, with clear acknowledgement of both the privilege and oppression that shape women's experiences of politics. For example, women who practised politics in the ways that Lake's work described were engaging in real struggle, as - and on behalf of-oppressed and subordinated subjects. But these women were also relatively privileged and were able to practise the kinds of politics they did because they had access to time and resources that many other women, including Indigenous Australian women, nonEuropean women, elderly women and many poor and working-class women, typically did not. Lake's work is clear to emphasise that many socially privileged women used their relative power to advocate on behalf of more vulnerable women-and vulnerable subjects generally.

Failing to critically consider the sites where women have practised politics (even when these are oppressive sites), however, risks reaffirming the privileged position of the male political subject and the normativity of men's political ideals and institutions. With recognition of these tensions, scholars like the authors of Creating a Nation have argued that it is not 
enough to simply insert women into the dominant, and predominantly masculine, narrative about Australia. Lake, for example, suggested other Australian feminist scholars, including Anne Summers in Damned Whores and God's Police (1975) and Miriam Dixson in The Real Matilda (1976) had done this. ${ }^{17}$ Even if Summers and Dixson had done so to highlight women's subordination in patriarchal society, they were arguably limited in their critical capacity because they had remained within a patriarchal framework. According to Lake, they therefore served implicitly to reinforce that framework and narrative, which assumed the normative citizen was a masculine subject. Lake argued that it was necessary, instead, to cultivate a new story that acknowledged and respected women's experiences and perspectives as central to Australia's story. As Lake wrote, she and the other authors of Creating a Nation 'aimed not so much to discredit the old stories as to advance a new one, with women not alienated from, but central to, nation-building..$^{18}$ In doing so, they sought to construct 'the national subject as feminine', rather than constructing women as national subjects. Such a distinction is significant. The latter would arguably amount to constructing women, conceptually, as masculine subjects because the 'national subject' (the normative citizen) was based on a particular, male experience of citizenship.

Lake also described how a rigid conceptualisation of 'politics' had rendered many of women's political contributions invisible to those who recorded political histories. For example, referring to Judith Smart's study of the citizen activism of the largest women's organisation in Australia of its time, the Victorian Housewives Association and the Federated Association of Australian Housewives, Lake described how the organisation's leader, Cecelia Downing, had 'effectively disappeared from public memory while the names of some contemporaries, such as Enid Lyons, have survived'. ${ }^{19}$ She argued that, because Lyons had entered institutional politics, it would seem that political power, like sexual power, has to be visible to be seen to exist'. ${ }^{20}$ Lake suggested that Lyons is celebrated while Downing is not because Lyons was the first woman to be elected to an Australian parliament (albeit toward the end of what had already been a long political life outside of institutional politics), and because parliaments 'have solid visual form'. ${ }^{21}$

17 Ibid., 154

18 Ibid., 155

19 Ibid., 160.

20 Ibid.

21 Ibid. 
Lake's critiques of liberal or egalitarian feminist approaches to documenting women's political histories arguably positions her work within a feminism of difference. Feminisms of difference emerged from the 1970s and 1980s within the context of, for example, the feminist theory emerging from France as well as women's liberation and countercultural movements in the West that focused on celebrating or valorising, rather than transcending, the female position. Lake's work challenges notions of citizenship and politics that exclude women's actual experiences of politics, and she sought to construct women as political subjects based on women's distinct experiences outside of the privileged, masculine institutions. Lake aimed at reimagining women as legitimate political subjects rather than 'political failures'; I argue further that there remains a risk of reinforcing the normativity of masculinist modes of citizenship if we valorise women's political practices while characterising them as primarily a means to an end or a way of 'making do'. Even Lake, who defended Australian suffragists and postsuffrage feminists (whose goals were not necessarily to enter parliament but to influence policy in different ways, including by voting), wrote that women's 'distinctive modes of doing politics' were formed by women's 'lack of mobility and autonomy'. ${ }^{22}$ As I argue with this paper, feminist scholarship should be critical of characterising women's political activities as 'lacking', and should be developing ways of conceptualising it, as I describe, as legitimate and 'whole'. Such reconceptualisations are significant for feminist theorising. While it would be reckless to deny women's suffering based on our social, political and cultural subordination and oppression, we must also ask how we could engage in more critical approaches that disrupt the normativity, or false universality, of the masculine subject. I suggest that Irigaray's feminist philosophy offers ways of reimagining and reconceptualising women's non-institutional and non-party political practices in such ways.

\section{An Irigarayan Politics as (Women's) Radical Politics?}

Luce Irigaray is most well-known for her critiques of the phallocentrism of Western philosophy and psychoanalysis (particularly in Speculum of the Other Woman, in which she offers a substantial critique of the works of Plato 
and Freud). She is also known for her thought on sexual difference and for her assertion of the ontological, not only socially constructed, nature of what she terms 'sexuate' identity. Her work critiques a phallocentric culture of 'sexual indifference' that positions 'Man' as the universal (or neutral) subject and 'Woman' as the 'particular' - that is, a deviation from the male subject. 'In Speculum', she later wrote, 'I interpret and critique how the philosophical subject, historically masculine, has reduced all otherness to a relationship with himself-as complement, projection, flipside, instrument, nature—inside his world, his horizons. ${ }^{23}$

Throughout her work, Irigaray develops an argument for rethinking sexual difference, and feminism, based on a rethinking of the categories of subject and other. In response to Simone de Beauvoir's work in The Second Sex (1949), she argues that women should indeed lay claim to the position of 'other' rather than transcending it (as she suggests Beauvoir's work advocates). She critiques Beauvoir's thinking on the categories of 'subject' and 'other', in particular suggesting that Beauvoir fails to critique the implicit masculinity of the 'subject' in Western thought and culture. Irigaray suggests that by laying claim to the category of 'other' - a category that is different to the masculine subject-women could cultivate our own subjectivities, rather than aiming to join the already existing masculine subject position. In a 1995 paper, Irigaray described her position as the 'inverse' of Beauvoir's, 'as far as the question of the other is concerned'. ${ }^{24}$ She had earlier described the conceptual position of women in patriarchal thought and culture as the other side of the sex that alone holds a monopoly on value: the male sex'. ${ }^{25}$ Rather than aiming for equality, or for women to join men in the position of the subject, Irigaray argued that subjectivity itself needed to be rethought in the West to acknowledge the possibility of (at least) two different but non-hierarchical subjects. She wrote, for example:

The question of the other has been poorly formulated in the Western tradition for the other is always seen as the other of the same, the other of the subject itself, rather than an/other subject, irreducible to the masculine subject and sharing equivalent dignity. ${ }^{26}$

23 Luce Irigaray, 'The Question of the Other', Yale French Studies, no. 87 (1995): 10.

24 Ibid., 8.

25 Luce Irigaray, This Sex Which is Not One (Ithaca, New York: Cornell University Press, 1977/1985),

26 Ibid. 
Such a logic, as Irigaray's argument goes, denies women a subject position in our own right and in our own terms; women do not occupy a position as 'woman' but are relegated to the position of 'not-man'. In this sense, women are positioned only ever in relation to the supposedly universal, neutral and stable subject: 'Man'. Irigaray's philosophical work is in this sense grounded in her commitment to affirming women's specificity (while acknowledging the plurality among and between women) and therefore a subjectivity of our own. She argues that such a subjectivity is not currently represented (or indeed possible) in Western thought and culture. Her philosophical work is therefore concerned with not only critiquing the phallocentrism of Western thought and culture but, as Margaret Whitford describes, with working out the conditions of women's subjectivity-how women can assume the "I" of discourse in their own right'. ${ }^{27}$

These perspectives have informed what is known as the 'creative' (as opposed to the critical) phases of Irigaray's work as well as a lengthy discussion, in Irigaray's second feminist text This Sex Which is Not One (first published in French in 1977 and translated into English in 1985), on politics and women's political practices. Irigaray discussed women's relations to politics and the need for women to cultivate a 'new' politics-particularly in the context of the women's liberation movements in France, and elsewhere in the West, in the 1970s. In her discussion on politics, Irigaray argued that women of this time needed to create a politics that did not reinforce political practices, ideals and systems that men had typically adopted. She critiqued then conventional modes of practising politics, arguing that 'strictly speaking, political practice, at least currently, is masculine through and through'. ${ }^{28}$ She also argued that a feminist politics that emulated the ways that men had practised politics would be limited in its transformative capacity. For women to be able to make ourselves heard, Irigaray argued, 'a "radical" evolution in our way of conceptualising and managing the political realm is required'. ${ }^{29}$ She wrote:

No "women's politics" exists, not yet, at least not in the broad sense. And, if such a politics comes into existence one of these days, it will be very different from the politics instituted by men.

27 Margaret Whitford, Luce Irigaray: Philosophy in the Feminine (London; New York: Routledge, 1991), 42 .

28 Irigaray, This Sex, 127.

29 Ibid. 
For the questions raised by the exploitation of women's bodies exceed the stakes, the schemas, and of course the "parties" of the politics known and practiced up to now. ${ }^{30}$

Irigaray's scepticism about women's entrance into the kinds of politics 'known and practiced to now' meant that she warned against the merits of 'equality feminist' aims, including advocacy for the equal representation of women and men in political institutions. She argued that political parties could 'co-opt' the so-called woman question by 'granting women a place in their ranks' and argued that such gestures were merely aimed at 'aligning [women] —one more time ...-with their "programs", which most of the time, have nothing to do with them, in the sense that these programs fail to take into consideration the specific exploitation of women'. ${ }^{31}$ Not only did Irigaray, in this sense, reject prioritising women's entrance into male political systems (which would amount to women fulfilling the role of dutiful daughter, upholding the rule and existing practices of men), but she emphasised that, for her, women's exploitation was deeper than the level of material or social oppression. She said that the exploitation of women does not constitute a limited question, within politics, one which would concern only a "sector" of the population or a "part" of the "body politic"'. ${ }^{32}$ Irigaray argues rather, as the psychoanalytic aspects of her work seek to demonstrate, that women's oppression is grounded in and perpetuated by the lack of symbolic representation of women and women's experiences in Western thought and culture. Women's bodies, desires and language have been denied expression in women's own terms: the culture (including political theories and practices) that women inherit is a masculine one. In this sense, egalitarian feminist aims are considered highly conservative. Irigaray's feminist aims are much more radical:

When women want to escape from exploitation, they do not merely destroy a few "prejudices", they disrupt the entire order of dominant values, economic, social, moral, and sexual. They call into question all existing theory, all thought, all language, inasmuch as those are monopolised by men and men alone. They challenge the very foundation of our social and cultural order, whose organisation has been prescribed by the patriarchal system. ${ }^{33}$

30 Ibid., 165.

31 Ibid.

32 Ibid.

33 Ibid. 
Importantly, while Irigaray points out the limitations of egalitarian feminisms, she does not deny the need for material and social rights-nor the need to demand these in an organised way. She cautions, however, that while women must 'continue to struggle for equal wages and social rights, against discrimination in employment and education, and so forth', this is 'not enough'. ${ }^{34}$ Women 'merely "equal" to men', she said, 'would be "like them", therefore not women'. ${ }^{35}$ In other words, aims for equality leave existing conceptions of the 'subject' intact, and this is a singular, masculine subject—one cultivated by men.

Whitford suggests that Irigaray 'does not recommend that women enter the political arena as it at present exists' but that she accepts 'that this can be a strategic necessity'. ${ }^{36}$ Whitford also suggests that it 'would be very easy to misread' Irigaray's position as not taking women's social and material oppression seriously. However, she argues that Irigaray's aim of a transformation of 'the foundation of our social and cultural order' is not dismissive of more immediate political concerns: ${ }^{37}$

In fact, Irigaray suggests that we need to distinguish between struggle and critique on the one hand, and the long-term vision on the other. The local struggles are important, even essential, but to lose sight of the larger objective would mean that women become assimilated to the world of men and then have nothing to contribute as women (as is made clear by the problems inherent in applying classical liberal theory to women)..$^{38}$

In other words, equal rights should, for Irigaray, be considered a means to an end and not the end itself. She emphasised, for example, that claims to social freedoms 'must never disguise the fact that it is in order to bring their difference to light that women are demanding their rights. ${ }^{39}$ To therefore avoid the differences between women and men being 'cancelled out, ignored, papered over' by becoming assimilated into the 'world of men', Irigaray argued that it was essential 'for women among themselves to invent new modes of organisation, new forms of struggle, new challenges'. ${ }^{40}$ She recognised that the women's movements in the

34 Irigaray, This Sex, 165-6.

35 Ibid.

36 Whitford, Philosophy in the Feminine, 12.

37 Irigaray, This Sex, 165.

38 Whitford, Philosophy in the Feminine, 12.

39 Irigaray, This Sex, 166.

40 Ibid. 
West at this time had already begun to do this, particularly through women's ways of gathering together through consciousness-raising groups. However, she implored that 'innovation is necessary: institutions, hierarchy, and authority - that is, the existing forms of politics—are men's affairs' and 'not ours'. ${ }^{41}$ She warned that if 'women allow themselves to be caught in the trap of power, in the game of authority, if they allow themselves to be contaminated in the "paranoid" operations of masculine politics' then women will 'have nothing more to say or do as women'. ${ }^{42}$

Anti-essentialist and poststructuralist feminists have been understandably wary and critical of Irigaray's work because her arguments are grounded in an affirmation of women's specificity and difference from men. Some argue that this risks falling into (or indeed does fall into) essentialist claims about precisely what this difference is or where it originates. Questions about apparent essentialism in Irigaray's work remain a topic of debate in Irigarayan scholarship. However, it is important to understand and acknowledge the philosophical interventions that Irigaray's work offers to feminist thought-in particular, her rethinking of subjectivity, the category of the other, and difference. In terms of thinking about women's experiences of politics, this helps us to ask important questions about women, citizenship and political subjectivity. If women are granted access to phallocentric political institutions, what legacy do we inherit? What political subjectivity do we occupy? If women practice politics in the ways that men conventionally have done, what systems, ideals and institutions does this sustain? And, on the other hand, what would a political subjectivity articulated and cultivated in women's own termsand in a way that disrupted the logic that positions women always ever in relation to men-look like?

\section{Reading Women's Political Theories and Practice in Australia as Radical}

Many parallels with Irigaray's calls for feminist innovation in political practice can be found in Lake's interpretations of women's nineteenth-and twentieth-century political theories and practices in Australia. As discussed previously, Lake has aimed to counter the myth that women in Australia 
lacked a robust political history by drawing attention to the energetic and influential ways that women practised politics as activists, advocates, writers, speakers, community members and 'citizen politicians'. Could the political practices that women engaged in throughout the nineteenth and twentieth centuries in Australia (and that women continue to engage with in twenty-first-century Australia) embody the 'new' political practices that Irigaray advocated for in the 1970s? Lake has emphasised that women's political thought and practices were distinct. In other words, they were not merely 'deficient' versions of men's political practices and ideals but were often based in active critiques of institutional and party politics. The anti-party stance of feminists like Louisa Lawson, Vida Goldstein and Rose Scott as documented in Lake's work, for example, were often grounded in a rejection of conventional political practices.

Lake's work has also highlighted the ways that nineteenth- and twentiethcentury feminists' approaches to politics in Australia often sought to foreground, rather than neutralise, women's specificities and the unique perspectives, experiences and oppressions of women. Lake has suggested, for example, that it was faith in the collective power of the vote as an expression of woman-power that ... animated feminists' strong opposition to women's engagement in party politics'. ${ }^{43}$ It was assumed that 'if women's interests were subsumed in men's parties, "woman's voice" would be rendered inaudible'. ${ }^{44}$ Later feminists, Lake suggested, had 'some difficulty in coming to terms with the priority accorded by suffragists to voting rights' (over parliamentary representation). She argued that this risked misunderstanding and misrepresenting Australian suffragists' political purpose, however, 'which was broad social reform, not merely or primarily, the advancement of women'. ${ }^{45}$

Australian suffragists including Louisa Lawson explicitly opposed women's engagement in party politics. In 1890, pre-suffrage, Lawson had written in The Dawn, for example, that 'few women would care for such a [parliamentary] post' and that 'there is no woman who would not think of her baby and the happiness of her home long before she desired in her wildest fancies the barren honour of a parliamentary seat'. ${ }^{46}$ There are problems with Lawson's characterisation of a parliamentary

43 Lake, 'Feminist History as National History', 164.

44 Ibid.

45 Ibid.

46 Louisa Lawson, 'Women Members', Dawn, June 1890. 
position as a 'barren honour' and her categorical characterisation of parliament as a place 'unfit for women' (and presumably unable to change), of course. Irigaray's feminist perspective, for example, does not deny the importance of women being in the positions of greatest societal power. However, we must also be critical of the ways in which institutional political places and systems might be unfriendly to women or unable to serve and respond to women's experiences (like motherhood), needs and desires-as Lawson suggests here. As Lake suggested, the goal for many feminists at the time of the women's suffrage campaign was not, in many instances, women's equal representation in parliament but the power of the ballot. ${ }^{47}$ Many feminists refused to participate in institutional politics on men's terms, and the parliamentary system was considered one of them. Rose Scott similarly opposed women's participation in institutional politics. She said, in a 1904 address to the Women's Political Education League, for example, that 'our place as women is not as camp followers to a corrupt system of Party politics, but as women to be men's inspiration to higher and nobler methods of governing a country'. ${ }^{48}$ She described, further, how:

At both Federal and State elections we issued manifestos urging women to keep away from sectarianism and party politics, and to work for the interests of women and children which have been so long neglected. Many who saw no reason in this warning have since assured me that they are now quite convinced, through bitter experience, of the necessity for women (who desire to work for reform in a whole-hearted manner) to keep apart from the factions and fights of men. ${ }^{49}$

Feminists in Australia like Scott were adopting critical political practices outside of men's institutions as legitimate alternatives to the political status quo-not (or at least not only) because of a lack of masculine political power. Vida Goldstein similarly had strong anti-party ideals, though she campaigned as an (independent) electoral candidate. She wrote in the journal Woman's Sphere in 1903, for example, that:

Women should carry on the fight and the campaign by means of their own organisations, and not by means of any of the existing ones controlled and directed by men. If they do the latter, they

47 Lake, 'Feminist History as National History', 164-5.

48 Rose Scott, President's Address to the Women's Political Education League, 1904, Mitchell Library.

49 Ibid. 
must adopt men's methods and men's aims, and simply help in perpetuating the old order of things. The right of the franchise will have been bestowed on them for no purpose. ${ }^{50}$

Later, in 1909, in The Woman Voter, Goldstein again defended feminists' non-party stance, writing:

By adopting (a non-party) policy it is not to be supposed that we are a body of gelatinous creatures, who have no definite views. We have all got very decided views as to the merits of the various political parties - some of us are protectionists, some are socialists, but we differ from those organised on party lines in one important particular. We believe that questions affecting the welfare of children, the present salvation of the criminal and the depraved, the moral, social and economic injustice imposed on women-we believe that all these questions are greater than party, and that in nine cases out of ten they are sacrificed to party interests. ${ }^{51}$

As Irigaray is critiqued for affirming women's specificity, feminists like Lawson, Goldstein and Scott were criticised by later feminists for their seemingly conservative or separatist views. For example, Judith Allen recalled in the preface to her book Rose Scott: Vision and Revision in Feminism what, at the time, 'an embarrassment earlier women's movement activists like Scott were to young feminists in the 1970s' because of, in this case, Scott's firm opposition to mixed-sex surf bathing in Australia. ${ }^{52}$ Irigaray has argued for the necessity of female places and spaces for women (where we could cultivate our subjectivities and 'sexuate' identities), but critiques of her as separatist or conservative are limited. Irigaray makes it clear that she opposes a strictly separatist feminist agenda. In This Sex Which is Not One, for example, she argued for the significance of a 'female-to-female sociality', but she emphasises that a female sociality should not signify a mere reversal of the patriarchal order. A female-to-female sociality is necessary for feminist politics, she argued, because women 'have always been put in a position of mutual rivalry' and so 'to make their own efforts more effective, they have had to constitute a place where they could be "among themselves". ${ }^{53}$ Such places could be a 'place for individual and

50 Vida Goldstein, 1903, quoted in Lake, Getting Equal, 145.

51 Vida Goldstein, The Woman Voter, no. 1, August 1909; Anne Summers, Damned Whores and God's Police: The Colonization of Women in Australia (London: Allen Lane, 1994), 412.

52 Judith Allen, Rose Scott: Vision and Revision in Feminism (Melbourne; New York: Oxford University Press, 1994).

53 Irigaray, This Sex, 160. 
collective "consciousness-raising" concerning the specific oppression of women, a place where the desire of women by and for each other could be recognised, a place for them to regroup' ${ }^{54}$ But she warned that womenonly spaces were in danger of becoming a utopia of historical reversal, a dream of reappropriation of power'. ${ }^{55}$ Women's political activities have often been, and continue to be, practised in groups with other women. It is important to consider the significance of these female-only or femaledominated spaces, particularly in terms of what they might offer for the cultivation of women's political subjectivities and political practices.

\section{Women's Modes of Politics as an Irigarayan Politics of Relationality}

While Irigaray's early work focused on the need for women, specifically, to cultivate a different approach to doing politics, she has written more recently on the need to develop a new mode of doing politics more generally. Her recent writing on politics offers further resources, I suggest, for reconceptualising women's non-institutional political theories and practices because of her particular attention to relationality. As Lake's work demonstrated (particularly in the 1990s), women's political activity has historically occurred with closer relation to the realms of society that are closest to the home and often in 'informal' groups together with other women. (And it still often does in contemporary Australia.) Women's closeness to the home, family and local community-as well as the associated closeness and attention to natural (and bodily) rhythms — can be characterised as limitations or barriers to women's political subjectivity or citizenship. However, Irigaray's privileging of relationality and attention to nature in her recent rethinking of politics might enable us to think of these aspects of women's political activity in new ways. In a 2019 interview, for example, Irigaray suggests that, 'a new global politics based on the respect for life is necessary', and she begins to imagine what this politics might be and how it could be enacted. ${ }^{56}$ This attention to care and relationality in Irigaray's work has some parallels with feminist writing on developing an ethic of care. In Lake's more recent work, for example,

\footnotetext{
54 Ibid., 160-1.

55 Ibid.

56 Luce Irigaray and Stephen Seely, 'What Does It Mean to Be Living?' PhiloSOPHIA, 8, no. 2 (2019): 8.
} 
she has emphasised the ethic and politics of care that grounded many women's political theory and practice in the nineteenth and twentieth centuries in Australia. ${ }^{57}$

In Irigaray's recent writing on politics, she speaks of desiring a politics that is grounded in 'care about oneself' and that does not rely on a 'codified and presumably neutral civic identity, which cuts [one] off from their real "identity". ${ }^{58}$ For Irigaray, this care of oneself would ground a 'politics between two. ${ }^{59}$ She also describes how, in imagining a new politics, she had begun to practice 'a politics of the relation between two', which she said 'allows for the respect for life and difference(s) — at each time and on any occasion of the day' ${ }^{60}$ She added that she 'also understood that my undertaking was above all to work on the elaboration of a new cultural background from which a new way of practicing politics could little by little arise'. ${ }^{61}$ The politics that Irigaray imagines could (or indeed should), in this sense, begin at a cultural level, rather than a systemic level-from the bottom up. She suggests that we must develop a new way of relating before we can develop a new politics, or perhaps that this way of relating could be a mode of politics in itself —or a way of bringing about political change. This is not a new development in Irigaray's thought. Her writing in the 1990s and 2000s began to elaborate this notion of relational politics 'between-two', based in an ethic of love and her thinking on 'intersubjectivity' (including, I Love to You [1996], Democracy Begins Between Two [2001], The Way of Love [2002] and Sharing the World [2008]). Her more recent philosophical works (such as Through Vegetal Being [2016], To Be Born [2017] and Sharing the Fire [2020]) bring themes of the 'natural' world, life and natural rhythms to the foreground. Could the attention to the care of oneself and relationality between (at least) two be found in the ways that women in Australia have practised non-party and non-institutional politics? Could we describe what Lake considered to be women's 'distinct' modes of practising politics as an Irigarayan relational politics, and, in this sense, a radical politics?

57 Lake, 'Subjective Femininities and Feminist Subject Positions'.

58 Irigaray and Seely, 'What Does It Mean to Be Living?', 6.

59 Ibid.

60 Ibid.

61 Ibid. 


\section{Writing About Women's Historical and Contemporary Political Practices with Irigaray}

In this paper, I have responded to Marilyn Lake's call to develop new feminist conceptual frameworks for understanding women's political practices by looking to the work of French feminist philosopher Luce Irigaray. I have argued that it is not enough to merely document women's non-institutional and non-party political activities without adopting a critical feminist approach. Doing so, I have argued, risks reinforcing the normativity of masculine modes of politics, citizenship and subjectivity, and characterising women's distinct modes of politics as merely lacking or deficient forms of 'real' politics. Instead, I have suggested that it is possible to reconceptualise women's distinct modes of politics as a radical—and perhaps Irigarayan-politics that actively challenges the conventions of male political power, citizenship and practices. Conceptualising women's political practices in this way disrupts the false universality of the masculine political subject and phallocentric notions of 'politics'. I have shown how Irigaray's work can inform such an approach. I have considered Irigaray's writing on the need for women to create new modes of doing politics that do not emulate existing, masculine politics as well as her argument for the disruption of the universality of the masculine subject and the articulation of women's subjectivities. The discussion outlined in this paper could, I suggest, inform ways of telling women's political histories and of understanding women's contemporary experiences of noninstitutional politics in new ways. By thinking about women's politics as radical rather than as deficient, I argue that it is possible to conceptualise women's political histories as legitimate and meaningful political histories, and women's political practices as constituting a legitimate and meaningful politics. 



\title{
Religious Dress and the Making of Women Preachers in Australia, 1880-1934
}

Kerrie Handasyde

University of Divinity

\begin{abstract}
What women preachers wore was a source of fascination for the press who regularly reported on their attire and decorum, as if respectable dress might mitigate the transgression that was a woman's preaching. For women, however, putting on religious dress represented the putting on of a right to minister and to speak: a making of the self anew. This article examines a range of late nineteenth- and twentieth-century reports in mainstream media and denominational journals for what they reveal about the relationship between women's clothing and the representation of gender and religious authority. Building on the work of feminist historians on media representations of women preachers, the article brings a number of previously unexamined sources into view. With an awareness of Protestantism's historical privileging of speaking and listening over seeing, the article finds that denominational approaches to visual culture in general, and women's dress in particular, influenced the reception of women's ministry.
\end{abstract}

When Chave Collisson fronted the media to promote Maude Royden's 1928 preaching tour of Australia, she exhorted critics not to approach 'the women's movement as that washing-day feeling ... but as the best-frock-day feeling'. ${ }^{1}$ Royden would be wearing 'charming clothes', Collisson assured reporters, for women preachers represented a new, yet recognisably feminine expression of religiosity and professionalism. Her response addressed the reality that women's preaching constituted a modern spectacle; a performative act in which gendered identity,

1 'Maude Royden, Welcome Plans', Sun, 14 February 1928, 19. 
and religious authority, was styled and ritualised. ${ }^{2}$ They could appear neither drab and dour nor overtly sexual for, despite centuries in which Protestantism privileged speaking and hearing the Word of God over the visual spectacle of the Catholic mass, women preachers knew that they were watched (objectified, monitored, minded) as often as they were heard.

This article examines reporting on women preachers' dress in mainstream media and denominational presses in the late nineteenth and early twentieth centuries in three Protestant denominations: The Salvation Army, the Presbyterian Church and the Churches of Christ in Australia. The sources, many new to scholarship, are read with an eye to both visual culture and the socio-religious role of dress in each denominational context. Historians have made connections between the authorisation of women's ministry and factors such as patterns in church governance, theological constructions of priest and pastor, education of women, biblical liberalism and church women's guilds. ${ }^{3}$ However, this article observes new aspects of the relationship between visual culture and women's religious authority in Australia that are important in the story of the reception of women as preachers and, more generally, in the social control of women.

Women's dress has long been recognised as a tool of social control in religious communities. The church as the Body of Christ effectively monitored and contained the bodies of women by maintaining expectations around acceptably modest dress. With conformity to dress codes (some denomination-specific, and some demurely conservative variations on the cultural mainstream) came social inclusion and the internalising of religious and social assumptions around gender and behaviour. ${ }^{4}$ Liberation, if a 'calling' that was so closely monitored can be named as liberation, would require a new dress for a new way of appearing in public and before the Body of Christ. For women officers in The Salvation Army,

2 Liz Conor, The Spectacular Modern Woman: Feminine Visibility in the 1920s (Bloomington: Indiana University Press, 2004), 7, doi.org/10.7202/018846ar; Judith Butler, 'Performative Acts and Gender Constitution: An Essay in Phenomenology and Feminist Theory', Theatre Journal, 40, no. 4 (1988): 519-20, doi.org/10.2307/3207893.

3 For example, Julia Pitman and Peter Bentley, 'Women Ministers Before 1977: An Update', Church Heritage, 21, no. 1 (2019): 23.

4 For example, Beth Graybill and Linda B Arthur, 'The Social Control of Women's Bodies in Two Mennonite Communities', in Religion, Dress and the Body, ed. Linda B Arthur (Oxford: Berg, 1999), 9, doi.org/10.2752/9781847888839/reldrbody0006; Joan Kendall, 'The Development of a Distinctive Form of Quaker Dress', Costume, 19, no. 1 (1985): 58-74, doi.org/10.1179/cos.1985.19.1.58; and, on Mormon dress, Colleen McDannell, Material Christianity: Religion and Popular Culture in America (New Haven: Yale University Press, 1995), 198-221, doi.org/10.2307/3170490. 
their public ministry meant the adoption of a military-style uniform; for Presbyterian deaconesses, ministry came with a neat blue dress with white collar and cuffs; and, for the first woman minister in Churches of Christ, a denomination where uniforms and clerical dress were disapproved of, preaching combined with a sartorial inventiveness that confounded the church into watchful silence.

Each of these denominations understood ministry as a role that was pastoral (or shepherding) rather than priestly, thus removing the significant barrier to women's ordination that the theology of a mediating priesthood presented. In denominations such as Anglicanism, the priest mediated Christ to the people through his own body. Thus, it was argued, seeing as Christ was a man, he must be mediated through and represented in the body of a man. While Protestant churches with a pastoral understanding of ministry did not face this issue of the need for women to bodily represent Christ, they inferred prohibitions on women's preaching from scripture. Carefully chosen verses from the New Testament defended preaching as the prerogative of men, and silence as that of women. ${ }^{5}$ Needless to say, they did not pay great heed to those New Testament verses in which Phoebe, Priscilla and Junia lead the churches, or Philip's four unmarried daughters prophesied. ${ }^{6}$

Despite broad nineteenth-century consensus that scripture barred women from preaching, churches that prized the individual experience of salvation (especially those in the Holiness tradition, which includes Methodist, Salvation Army and Pentecostal churches) found that some women's preaching could be countenanced as a special gift of God through the Holy Spirit. For women in the Pentecostal movement, authority came through personal encounter with the Holy Spirit. For instance, after experiencing Holy Spirit baptism, Sarah Jane Lancaster established her own church in North Melbourne in 1909, the first Pentecostal church in Australia. ${ }^{7}$ Mediation of the Holy Spirit through the body of a woman meant that women could act not under their own authority, but as conduits of the

\footnotetext{
5 For example, 1 Corinthians 14:34-35; 1 Timothy 2:12.

6 Romans 16:1-7; Acts 21:8-9.

7 Shurlee Swain, 'Lancaster, Sarah Jane', The Encyclopedia of Women and Leadership in Twentieth Century Australia, Australian Women's Archive Project (2014), www.womenaustralia.info/leaders/biogs/ WLE0330b.htm; Kerrie Handasyde, 'Mother, Preacher, Press: Women Ministers and the Negotiation of Authority, 1910-1933', in Contemporary Feminist Theologies: Power, Authority, Love, eds. Kerrie Handasyde, Cathryn McKinney and Rebekah Pryor (Abingdon: Routledge, forthcoming).
} 
Spirit. Two millennia of Christian women have attributed their ministries to the actions of the Spirit through them: early twentieth-century Pentecostal women operated within a long tradition of prophetesses and mystics.

In churches that valued reason and pragmatism over experience, formal women's organisations offered a platform from which women could speak in public on moral and spiritual matters, and agitate for social and legislative change. ${ }^{8}$ In the late nineteenth to mid-twentieth centuries, women in mainline traditions formed Christian organisations including the Young Women's Christian Association, Anglican Mothers' Union, Presbyterian Women's Missionary Union and Woman's Christian Temperance Union, which campaigned not only against liquor but in favour of suffrage. A number of women active in suffrage campaigning moved from the town square soap-box to the church pulpit in the years after women achieved the vote. Maude Royden was among them. ${ }^{9}$ Chave Collisson's publicity for Royden's Australian preaching tour reveals the negotiations required of these women around received notions of femininity and religious authority in changing times.

As feminist scholars have observed-especially Shurlee Swain, Laura Rademaker and Diane Winston-what women wore when preaching was reported in the press with great interest. ${ }^{10}$ The role of dress in the establishment of women's Christian identity is well established in sociological studies, but in historical studies it is more often noted in the historiography of mission where religious conversion is signalled by the culturally problematic adoption of colonial styles of dress along with

8 Ellen Warne, Agitate, Educate, Organise, Legislate: Protestant Women's Social Action in Post-Suffrage Australia (Melbourne: Melbourne University Publishing, 2017).

9 Jacqueline R de Vries, 'Transforming the Pulpit: Preaching and Prophecy in the British Women's Suffrage Movement', in Women Preachers and Prophets through Two Millennia of Christianity, eds. Beverley Mayne Kienzle and Pamela J Walker (Berkeley: University of California Press, 1998), 318, doi.org/10.1525/9780520919273-020.

10 Shurlee Swain, 'In These Days of Female Evangelists and Hallelujah Lasses: Women Preachers and the Redefinition of Gender Roles in the Churches in Late Nineteenth-Century Australia', Journal of Religious History, 26, no. 1 (2002): 65-77, doi.org/10.1111/1467-9809.00142; Laura Rademaker, 'Religion for the Modern Girl: Maude Royden in Australia, 1928', Australian Feminist Studies, 31, no. 89 (2016): 336-54, doi.org/10.1080/08164649.2016.1254024; Diane Winston, Red-Hot and Righteous: The Urban Religion of The Salvation Army (Cambridge, MA: Harvard University Press, 1999), 17, doi.org/10.1086/ahr/105.4.1323. 
colonial expressions of Christianity. ${ }^{11}$ Dress has rarely been a concern of denominational historians who have tended to frame discussion of women's preaching within the machinations of internal church politics and belief. ${ }^{12}$ Smaller so-called unorthodox denominations, even those in which women held leadership roles, are particularly under-represented in major works of scholarship on women preachers. ${ }^{13}$ As Frank Bongiorno has noted, religious unorthodoxy has been neglected in Australian historiography, and this matters given that many women found their political voice in idealistic minority religious groups. ${ }^{14}$ They found their religious voice there too, as this article shows.

For women finding their voice as preachers, appearing mattered also. What to wear was a constant concern as dress represented to the congregation and to the world the woman's embodiment of the community's gendered moral codes and, thus, her moral and spiritual standing before God. ${ }^{15}$ In the discussion to follow, published writings about women preachers in The Salvation Army, the Presbyterian Church and Churches of Christ reveal that the relationship between dress and each denomination's reception of visual culture played a significant part in the authorisation of ministry.

11 For example, Pamela E Klassen, 'The Robes of Womanhood: Dress and Authenticity Among African American Methodist Women in the Nineteenth Century', Religion and American Culture: A Journal of Interpretation, 14, no. 1 (2004): 57, doi.org/10.1525/rac.2004.14.1.39; Deborah Gaitskell, 'Power in Prayer and Service: Women's Christian Organizations', in Christianity in South Africa: A Political, Social, and Cultural History, eds. Richard Elphick and Rodney Davenport (Berkeley: University of California Press, 1997), 257-8, 264, doi.org/10.1353/jsh.2000.0009; Elisha P Renne, 'Cloth and Conversion: Yoruba Textiles and Ecclesiastical Dress', in Undressing Religion: Commitment and Conversion from a Cross-Cultural Perspective, ed. Linda B Arthur (Oxford: Berg, 2000), doi.org/10.2752/9781847888938/undrel0006.

12 For example, Ken Newton, 'The Status and Role of Women in Australian [Brethren] Assemblies', Christian Brethren Review, 41 (1990); Sally Kennedy, Faith and Feminism: Catholic Women's Struggles for Self-Expression (Sydney: Studies in the Christian Movement, 1985).

13 For example, Anne O'Brien, God's Willing Workers: Women and Religion in Australia (Sydney: UNSW Press, 2005); Muriel Porter, Women in the Church: The Great Ordination Debate in Australia (Melbourne: Penguin, 1989). A Churches of Christ historian was prompted to write in response to Porter's omission of women in ministry in churches with differing understandings of ordination: William Tabbernee, 'Women and Pastoral Ministry in Churches of Christ', Digest of the Australian Churches of Christ Historical Society, 103 (1989).

14 Frank Bongiorno, 'In This World and the Next: Political Modernity and Unorthodox Religion in Australia, 1880-1930', ACH: The Journal of History and Culture in Australia, 25 (2006): 180, 191-4.

15 Klassen, 'The Robes of Womanhood', 40-2. 


\section{The Salvation Army and 'All Her Daring'}

When Captains Thomas and Adelaide Sutherland disembarked the Aconcagua to lead The Salvation Army in South Australia in 1881, she wore a plain dark dress and bonnet and he wore a military-style uniform with a brass helmet. ${ }^{16}$ It was only three years since The Salvation Army had changed its name from the East London Christian Mission and rejected its Methodist inheritance-clerical dress, sacraments and ecclesial language — in favour of a new narrative. ${ }^{17}$ Adopting a military metaphor that reflected the mission's battle for souls, The Salvation Army named its periodical The War Cry, prayers were known as knee-drills, congregations called army corps, street preaching termed 'firing a volley', and members were assigned military rank and military costumes. They expected heartfelt conversion (born out of direct experience of the divine and expressed in the emotive language of the heart that was characteristic of the Holiness Movement) and publicly represented their new-found salvation with the putting on of new clothes. These new uniforms were an outward manifestation of the narrative in which the members lived. The men's uniforms were, at first, a ragtag collection of cast-offs from the British army. They adopted an existing wardrobe and an existing metaphor for men's vocation. But there were no women in the British army, no castoffs to be had. Women Salvationists sewed their own uniforms, literally crafting a new self in preparation for initiation into a new life.

Uniforms provided Salvationist women with a new way of being in public. The dark blue dresses and bonnets signalled modesty, yet attracted attention to the cause. ${ }^{18}$ Women Salvationists in uniform were intended to be noticed in the streets and in the press-visual spectacle was integral

16 Barbara Bolton, Booth's Drum: The Salvation Army in Australia 1880-1980 (Sydney: Hodder and Stoughton, 1980), 13.

17 Roger J Green, The Life and Ministry of William Booth, Founder of The Salvation Army (Nashville: Abingdon Press, 2005), 30; Pamela J Walker, Pulling the Devil's Kingdom Down: The Salvation Army in Victorian Britain (London: University of California Press, 2001), 1, doi.org/10.3138/cjh.37.1.170. Military metaphors were popular in Victorian England, as witnessed in the proliferation of children's 'brigades' and missionary organisations such as the Anglican 'Church Army', carrying connotations of obedience, self-sacrifice and empire.

18 Lynne Marks, "The "Hallelujah Lasses": Working-Class Women in The Salvation Army in English Canada, 1882-92', in Gender Conflicts: New Essays in Women's History, eds. Franca Iacovetta and Mariana Valverde (Toronto: University of Toronto Press, 1992), 67-117, doi. org/10.3138/9781442675186-005. 
to the denomination's missionary strategy. ${ }^{19}$ Their uniforms authorised women to speak and to act for the transformation of lives. ${ }^{20}$ Significantly, they re-defined what was possible for women in the evangelical tradition. Four months after her arrival in Australia, missionary and preacher Captain Adelaide Sutherland was profiled in South Australia's Christian Colonist in terms that re-framed evangelical Christian femininity:

Far from manifesting a want of feminine feeling, there was a real charm about all her daring, yet she was ever ready for a charge straight over hedge or ditch to save. Nobody who saw her clamber over the seats of the Hall of Varieties at Newcastle to seize some penitent, but hesitating ruffian by the head or neck, and lead him out to the penitent form for salvation, can forget the emotion of admiration for her fervour and straight-forward, honest dealing with souls. ${ }^{21}$

Along with the women's Salvation Army uniform came a new vocabulary: fighting qualities could be ascribed to women missionaries in the cities.

In early Australian editions of The War Cry, women officers are profiled with words to fit their military-style clothes. Adjutant Cartner of Launceston, pictured in uniform, was described as 'True as steel ... a champion of God'. ${ }^{22}$ Ensign Sparks of Auckland would reportedly 'face men or devils in the interests of the fallen' ${ }^{23}$ Ensign Winter of Adelaide was 'especially adapted for ... uplifting the fallen and building them up to take their place once more in the battle of life' ${ }^{24}$ In uniform, these women were recast, re-born into a new rhetorical world of salvation soldiery. They were authorised to preach and to take part in the battle for souls in city streets. As Salvation Army co-founder Catherine Booth argued, mild-mannered 'effeteness' and concern with 'respectability' and 'reputation' hindered the saving of souls - what the world needed was 'Aggressive Christianity'. ${ }^{25}$

19 Kerrie Handasyde, God in the Landscape: Themes in the Literary History of Australian Protestant Dissent (London: Bloomsbury Academic, forthcoming).

20 For discussion of perceptions of women's ministry, see Shurlee Swain, Constructing the Good Christian Woman (Melbourne: Uniting Church Historical Society, 1993), 3-10; Anne O'Brien, God's Willing Workers: Women and Religion in Australia (Sydney: UNSW Press, 2005), 36-49, 100.

21 War Cry (British edition, issue number not cited) quoted in 'Mrs Sutherland', Christian Colonist, 1 July $1881,2$.

22 War Cry, 30 July 1898.

23 War Cry, 27 August 1898.

24 War Cry, 13 August 1898.

25 Catherine Booth, Papers on Aggressive Christianity (London: The Salvation Army, 1891), 'The Holy Ghost' 14, 'The World's Need' 12, 'Aggressive Christianity' 3. 
The battle was not only metaphorical but literal, as Salvationist street preachers were often attacked. The War Cry regularly ran lists of injuries, including bruises, concussions, lacerations and even the deaths of women officers. Such lists represented the Salvationists' embodied approach to evangelisation, to the upturning of social values, and to their perception of themselves as martyrs for the cause. ${ }^{26}$ Wearing the uniform, Mary Ann Cox proved a 'fiery, eloquent preacher' whose words provoked attack from a gang of youths to try to wrest the Salvation Army flag from her in Sydney's Domain. Reportedly 'wrapping it round herself and defying the mob to take it', she made herself anew, embodying The Salvation Army like a robed Britannia. ${ }^{27}$ Virtue joined with 'daring' in the new dress of Salvationists such as Mary Ann Cox and Adelaide Sutherland. ${ }^{28}$

Women from other denominations, especially Methodists and other churches influenced by the Holiness Movement with its emphasis on personal conversion, were drawn to The Salvation Army because of the opportunities it offered. Real equality between the sexes was in fact elusive, despite reports that 'the females seem to hold equal rank' (both Thomas and Adelaide Sutherland were afforded the rank of captain). ${ }^{29}$ However, women could preach and take on public ministries traditionally considered the province of men. Catherine Booth had long been an advocate of women's preaching, having published her Female Ministry: Or, Woman's Right to Preach the Gospel in 1859 in support of American Methodist and Holiness Movement preacher Phoebe Palmer, who came to Britain that year. Booth argued that much of the resistance to women's preaching resulted from a perception that ambition was 'unfeminine':

There seems to be a great deal of unnecessary fear of women occupying any position which involves publicity, lest she should be rendered unfeminine by the indulgence of ambition or vanity; but why should woman any more than man be charged with ambition when impelled to use her talents for the good of her race. ${ }^{30}$

26 War Cry (n.d.), cited in Bolton, Booth's Drum, 72. This tendency was also noted in 'The Salvation Army,' Kapunda Herald, 23 April 1886.

27 'How Army Flag Was Saved' (obituary for Mary Ann Sanders, née Cox) News, 26 November $1932,5$.

28 War Cry (British edition, n.d.) quoted in 'Mrs Sutherland', Christian Colonist, 1 July 1881, 2. Mary Ann Cox reportedly converted to The Salvation Army shortly before the Sutherlands were sent to South Australia, and was known at her death as the first woman member and officer of the Salvation Army in Australia': 'How Army Flag Was Saved', News, 26 November 1932, 5.

29 'The Salvation Army', South Australian Advertiser, 27 July 1881, 5.

30 Catherine Booth, Female Ministry: Or, Woman's Right to Preach the Gospel (London: Morgan and Chase, 1859), 4. 
Women's public preaching was endorsed by Catherine Booth and practised from the beginnings of The Salvation Army, and the uniform protected against accusations of vanity and pride.

The Army's insistence on a plain dark blue dress and bonnet required that women give up any outward sign of wealth or class or worldly ambition. In this way they would embody a way of living that empowered even as it invited mockery of their dressing up in pseudo-military costume. Women could wear no silk, no bustle, no jewels and no embroidery beyond the Army's insignia. ${ }^{31}$ This required a public rejection of accepted norms of femininity. ${ }^{32}$ It was a rejection that became part of the religious conversion narrative for many women in many denominations. As historian Diana Winston notes, a genre of writing developed within North American Salvation Army publications in which women hesitated to wear the dark, plain uniform for reasons of fashion. ${ }^{33}$ But then, in these conversion stories, Salvationists come to accept the uniform as they accepted a life in Christ. In the absence of the sacraments of baptism and Eucharist, it functioned something like an 'outward sign of an inward grace'. ${ }^{34}$

The correlation of costume with conversion is evident in the mainstream Australian press too. In 1890 the Seymour Express described a woman who 'had been a notorious character', but who had since 'donned the uniform, and [become] one of the most useful workers'. ${ }^{35}$ In 1897 the Bowral Free Press reported an officer's testimony that once she and her sister had 'got saved. My next impulse was to wear the army uniform'. ${ }^{36}$ The uniform came with an identity that subsumed all else. In Salvation Army weddings women did not wear bridal gowns but were married in uniform, often adding a white bridal sash. ${ }^{37}$ At death, officers were buried in uniform and coffins were draped with the Army's flag and the deceased's poke bonnet. ${ }^{38}$ In the vibrant visual culture of The Salvation Army, the uniform represented eternal salvation.

31 Winston, Red-Hot and Righteous, 86.

32 Lewis R Rambo, Understanding Religious Conversion (New Haven: Yale University Press, 1993),

33 Winston, Red-Hot and Righteous, 88-9.

34 Definition of sacrament commonly attributed to St Augustine.

35 Seymour Express, 5 December 1890, 2.

36 Bowral Free Press, 8 September 1897.

37 Evening News, 14 August 1899; Tasmanian, 26 November 1892.

38 Evening News, 20 February 1891. 
There was only one other costume that could better represent a woman Salvation Army officer's commitment to Christian ministry. The Salvation Army reported on its women officers' imprisonment as an indication of their great commitment to ministry, and it published staged photographs of women wearing prison garb as witness. ${ }^{39}$ In the 1880s and 1890s, the Salvation Army's noisy processions and preaching provoked opposition from the public, especially from publicans and their customers who were frequent targets of Salvationist evangelism. ${ }^{40}$ By-laws were introduced to limit street preaching and arrests were made. In 1891 when the Ballarat city council introduced by-laws to prevent the Army from marching, Salvationists were compelled by force of their own fighting and persecution narratives to court arrest under those laws. A group of officers, both women and men, was tried before the court. Then another group, and then another who travelled from Melbourne especially for the purpose. ${ }^{41}$ Refusing to pay fines, they were sent, with some hesitation on the part of the judge, to Ballarat Gaol. If the young officers thought themselves actors in a drama of sin and salvation, they had chosen an especially powerful stage on which to perform. This gaol was not a country lock-up but a high security prison in which three men were publicly executed that year, one of them for killing a cellmate. ${ }^{42}$

The newspapers reported that the Salvationists were not housed with other prisoners, but they were made to take off their uniforms and wear prison clothes. ${ }^{43}$ The authorities presumably hoped that such a loss might weaken the Salvationists' identity and resolve. Certainly, newspapers recognised the significance of the loss of that which made them so recognisable in the streets. The Argus noted that the Salvationists 'submitted quietly' to wearing prison dress. ${ }^{44}$ Their humble obedience to prison demands appeared as meekness to civil authorities, but in The Salvation Army's alternative worldview, submission to prison authorities was an act in emulation of Christ who 'humbled himself, and became obedient unto death, even the death of the cross' ${ }^{45}$ In the light of Holiness theology, if the uniform signalled salvation, prison clothes functioned as a sign of complete sanctification: a 'being made like Christ' who likewise suffered

39 Handasyde, God in the Landscape.

40 Bolton, Booth's Drum, 71, 76-80.

41 Age, 2 March 1892.

42 Ballarat Star, 21 April 1891, 2.

43 'The Salvation Army and the Ballarat City Council', Argus, 13 October 1891, 5.

44 Ibid., 5.

45 Philippians 2:8 (King James Version). 
at the hands of the authorities and the mob. ${ }^{46}$ Costume became part of the narrative of Salvationist incarceration. ${ }^{47}$ Joseph Perry, who ran the Salvationist's Prison-gate ministry, took pictures for The Army's press. The published image looks highly staged, but The Salvation Army understood well the power of clothing in the public performance of ministry.

\section{Presbyterian Deaconesses, 'Always Neat and Trim'}

For women ministering as deaconesses in the Presbyterian Church, both prison garb and garments designed for publicity would have been unthinkable. Indeed, when badges were introduced for deaconesses to wear while working with the poor in Melbourne streets, the women found they attracted attention and insult, and requested that they not be made to wear them. ${ }^{48}$ Instead, from 1898 , they wore a uniform of blue dress with white collar and cuffs that was intended to be a 'simple, but distinctive costume for protection and for recognition', but which was, in fact, somewhat anonymous in the absence of insignia or other distinguishing features. ${ }^{49}$ While the sources are silent on the matter, perhaps the deaconesses sought to avoid public confusion with the badges and blue dresses of rowdy, street preaching Salvationist women. Certainly, the Presbyterian Church in Victoria valued restraint and propriety, carrying with it to the colonies the establishment assumptions of the Church of Scotland, which were sustained, in part, by the wealth and influence of Scottish pastoral families in the western district. When the young Victorian women of the Deaconess Training Institute wore their blue-and-white dresses, they put on the colours of Scotland and publicly subscribed to the church's gendered expectations around restraint and propriety. In nineteenth-century Britain, Presbyterian women were initially assessed for missionary service on the basis of 'ladylike' qualities,

46 One of the accused, William Bowes was released against his will after his mother, who evidently did not ascribe to the extreme end of Holiness Movement theology, paid the fine: Bendigo Independent, 3 March 1892.

47 Report about the officers in the photo says they were 'clothed in prison garb': 'Salvation Army Troubles at Ballarat', Argus, 24 February 1892, 7.

48 Minutes of Executive Committee of the (Deaconess) Training Institute, East Melbourne, (n.d.), quoted in Catherine L Ritchie, Not to Be Ministered Unto: The Story of Presbyterian Deaconesses Trained in Melbourne (Melbourne: Uniting Education, Uniting Church in Australia's Synod of Victoria, 1998), 14 .

49 Minutes of Executive Committee of the (Deaconess) Training Institute, East Melbourne, 2 May 1898, quoted in Ritchie, Not to Be Ministered Unto, 14. 
while men were chosen for their education and leadership experience. ${ }^{50}$ Although the need for women's training was quickly recognised, being 'ladylike' persisted as a requirement. Women applying to the Deaconess Training Institute in Melbourne were asked to provide a character reference 'from a lady' and answer questions as to whether they could sing, or speak a second language. ${ }^{51}$ The missionary advantage of French or Latin in the streets of Melbourne would have been minimal, but languages suggested refinement.

The Institute's advertising leaflet reminded applicants of the New Testament example of Phoebe who was called 'not to rule' but to engage in 'helpful service'..$^{2}$ The particular interpretation of Phoebe's work and the blue dresses echoed the pronouncement of John Knox, sixteenthcentury Presbyterian founder, that women's garments are a witness to their weakness and inability 'to execute the office of men', insisting that women's rule was 'repugnant to Nature', 'the subversion of good Order'. ${ }^{53}$ Dress made known women's natural subordination, according to Knox. While both Presbyterian deaconesses and Salvationist women wore blue dresses, their costumes carried very different expectations around gender and religious authority. The Presbyterians' 'Blue Ladies' were a world apart from the 'daring' women officers of The Salvation Army and Catherine Booth's 'Aggressive Christianity..$^{54}$

Presbyterian deaconesses performed similar duties to those of women officers in The Salvation Army, especially in their ministry to the poor and ill and in their missionary evangelism, and some occasionally preached from the pulpit. However, the deaconesses represented decorum and social status even as they laboured to help the lowly. They were 'set apart' for ministry as deaconesses. ${ }^{55}$ This separation was evident in their

50 Rhonda Anne Semple, Missionary Women: Gender, Professionalism and the Victorian Ideal of Christian Mission (Woodbridge: Boydell and Brewer, Boydell Press), 192, doi.org/10.1086/ ahr/110.1.225.

51 'Rules of Applicants' (1898), quoted in Ritchie, Not to Be Ministered Unto, 12-13.

52 'Our Deaconesses and the Training Institute' (leaflet, c. 1898), quoted in Ritchie, Not to Be Ministered Unto, 10.

53 John Knox, 'First Blast of the Trumpet against the Monstrous Regiment of Women' (1558), quoted in Jane Dawson, John Knox (New Haven: Yale University Press, 2016), 142-3. Knox's injunction was aimed at least in part at the rule of Mary Tudor, but his pronouncements against ostentation in women's dress and the inadmissibility of women to leadership have proved powerful and persistent.

54 Booth, 'Aggressive Christianity'.

55 Commission of Assembly (May 1895), quoted in Ritchie, Not to Be Ministered Unto, 34. 
dresses that were 'always neat and trim'. ${ }^{56}$ Advertising for women to join the 'Blue Ladies', a 1930 article for The Missionary Chronicle describes them 'going into big State schools, being welcomed and escorted in by dirty little children, their spotless cuffs smeared by hot, loving hands'. They are seen visiting all manner of places a 'Lady' would never venture except as a deaconess working with women and children: factories, courts, a Chinese school, homes for unmarried mothers, pawnshops and 'waiting outside the gaol'. ${ }^{57}$ In all these places, the 'Blue Ladies' remained clean and respectable.

Significantly, the recruitment advertisement noted that a 'Blue Lady' could also be found 'preaching on Sunday in a little church' [emphasis added], although 'that Blue Lady had lost her smile!' In this depiction, another 'setting apart' is evident: while ministry among the poor required a smile, preaching the gospel was much more serious work. It was so serious that women were not ordained to the Ministry of the Word and the Sacraments in the Presbyterian Church in Australia until 1974 and, in the conservative remnant of Presbyterianism that remained outside the Uniting Church at union, no women have been ordained since $1991 .{ }^{58}$

Preaching by deaconesses was not common prior to the 1970s. When they did preach, it was most often as a guest speaker associated with a special church service organised by the Presbyterian Women's Missionary Union. ${ }^{59}$ Miss Hilda Wilson's ministry to the St Andrew's Presbyterian Church in remote Queenstown, Tasmania, was a rare exception. In 1952, '[o]wing to the acute shortage of clergy', Deaconess Wilson was ritually 'Set Apart' to 'do all the work normally carried out by a clergyman', including preaching and performing marriages (requiring a licence) and burials. ${ }^{60}$ Her remarkable circumstances led to an article in Melbourne's Age newspaper, where she is pictured smiling in her blue dress and white collar. Despite being 'Set Apart' by the church and licensed by the state, Hilda Wilson did not wear the garb of a clergyman but that of a deaconess: respectable and subordinate.

56 Advertisement to become a 'Blue Lady', Missionary Chronicle, June 1930, quoted in Ritchie, Not to Be Ministered Unto, 71-3.

57 Ibid., 71-3.

58 Porter, Women in the Church, 32.

59 'Church Budget - Presbyterian', Morwell Advertiser, 6 May 1954, 13.

60 'Deaconess to be "Set Apart", Mercury, 19 January 1952, 7; 'Presbyterian Deaconess Performs Marriages', Age, 25 October 1952, 14. 


\section{Churches of Christ and the Ambiguity of 'Sunday Best'}

Like Deaconess Wilson, the appointment of Violet Callanan to the ministry of the Church of Christ in Hawthorne, Queensland, was attributed to a dearth of suitable men. In the Churches of Christ there was no ritual of 'setting apart' as the denomination did not practise ordination. Instead, it professed the 'priesthood of all believers', denying any distinction between clergy and laity in the administration of the sacraments and preaching of the Word. ${ }^{61}$ Accordingly, preachers wore no clerical garb, no robes or vestments, but neat 'Sunday best'. A simple jacket and tie was expected. Ostentation was considered a sign of sin and so people dressed modestly for worship services in plain chapels with clear windows and only the words of scripture adorning the walls.

Despite their historical adherence to lay ministry, by the 1920s almost all Churches of Christ congregations employed men to preach. Paying their ministers with the often meagre proceeds of the congregation's offering bowl, no central ecclesial body had the right to oversee ministry appointments. When the 36 members of the Church of Christ at Hawthorne, Queensland, could not attract a minister, they quietly engaged the services of a young woman with a Foreign Missions Certificate instead. Violet Callanan was Hawthorne's minister from 1931 to 1934, the first woman in pastoral ministry in Churches of Christ in Australia.

Callanan studied for her Foreign Missions Certificate alongside men training for ministry-the denomination's College of the Bible only enrolled women for studies in missionary service. ${ }^{62}$ Annual college photographs show rows of men in ties, with women seated at the front, their heads covered in accordance with 1 Corinthians 11:2-6. The women wear hats and skirts with blouses and cardigans, but, like the men training for ministry of the Word, Violet Callanan wears a collared shirt and tie. ${ }^{63}$ It was a sign of things to come; her 'calling' to ministry and to the wearing of jackets and ties. Despite her serious attire, members of

61 Ordination was introduced in 1941: Graeme L Chapman, One Lord, One Faith, One Baptism: A History of Churches of Christ in Australia, 2nd ed. (Melbourne: Vital Publications, 1989), 144.

62 Kerrie Handasyde, 'Editorial', Historical Digest of the Australian Churches of Christ Historical Society, 177 (2012): 3.

63 Photo of 'Students at Glen Iris, 1928' and of students enrolled in Foreign Mission studies (College of the Bible, Glen Iris, Melbourne 1928), Australian Churches of Christ Archives, Mulgrave, Vic. 
the congregation joked about having a 'petticoat ministry', ${ }^{64}$ for no matter what she wore on top, as a woman in a man's job she was defined by her metonymic underwear.

Words mattered in Churches of Christ, but Callanan was barely spoken of in the denomination's press. The Church of Christ at Hawthorne kept news of her appointment quiet. In 1931, when Callanan's role began, women's preaching was in the national news: the Reverend Winifred Kiek, wearing the black gown of Congregationalist preachers, was engaged in a high-profile ordained ministry in Adelaide; and Methodist lay preacher Doreen Rita Allen, in her black undergraduate gown, demonstrated women's abilities in the pulpit as the Methodist Church debated the ordination of women in synods around Australia. ${ }^{65}$ The Churches of Christ's federal periodical reported on the news of Methodist debates, but made no mention of Callanan's ministry for many months. ${ }^{66}$ After nearly a year, Callanan's ministry was noted for the first time and simply as a local matter: a column with news from various churches says that at Hawthorne, 'Miss Callanan's addresses much appreciated'. ${ }^{67}$ In 1932 the Churches of Christ annual Conference Program mentions that 'Miss Callanan has been acceptably assisting Hawthorne Church' [emphasis added].${ }^{68}$ She presented herself as a minister in a tie and collared shirt, but the denomination viewed her as an assistant, a help meet to the church, just as in Genesis 2:18 where a woman was created in order to be a help meet to a man. Churches of Christ's organisation of locally autonomous congregations allowed for diverse beliefs, but major disagreements could put the denomination's continuing association at risk. Fracture was always possible and so controversy was avoided. The revolutionary nature of Callanan's role was confined as a local matter, undertaken with little public recognition and muted language.

The congregation grew under Violet Callanan and in such circumstances a minister might be expected to stay on or to move to a larger church. But Callanan did not go on to another pastoral ministry. Instead, she

64 '80th anniversary of Hawthorne Church of Christ' (Brisbane, 1994), 9. Queensland archival sources kindly supplied by Jonathan Smith, Queensland Churches of Christ Archives.

65 Julia Pitman, 'Prophets and Priests: Congregational Women in Australia, 1919-1977'

(PhD thesis, University of Adelaide, 2005), 240. For scholarship on Doreen Rita Allen and Winifred Kiek see Handasyde, 'Mother, Preacher, Press'.

66 HG Payne, 'News of the Churches: Queensland News-letter', Australian Christian, 28 April 1932.

67 'News from the Churches: Hawthorne', Australian Christian, 25 August 1932.

68 'Churches of Christ Annual State Conference Programme' (Queensland, 1932), 12. 
took a position with the church's social welfare department in Melbourne. After the minimal mention of her work at Hawthorne and no celebration of her status as the first woman minister, the church's national periodical reported enthusiastically on her new appointment: 'Miss Callanan has the distinction of being the first woman to be set aside for special social work'. ${ }^{69}$ She was to fulfil a role akin to that of Presbyterian deaconess, working among women and children in need. She put aside her collar and tie and adopted a new uniform of her own devising. It was a grey tunic with a veil, something like a nun's habit; she would be known as 'Sister'. Perhaps these clothes would bring her authority as they did women in other traditions. But the negative comments she received were overwhelming and she stopped wearing her self-styled habit. ${ }^{70}$ When she returned to Queensland to visit family and friends it was reported in the denominational press that she would also 'relate her experiences as Social Service Sister' to the congregation at Ann Street Church of Christ in Brisbane. ${ }^{71}$ No mention was made of her congregational ministry. Callanan's story of men's ties and nun's habits is not a narrative of passing: it is not about disguise, or playfulness, or the determination to live another life. ${ }^{72}$ This is about a woman who was equipped and chosen for ministry but whose female body, however she dressed it, lacked authority within the worshipping community. Whatever she wore, in the subdued visual culture of Churches of Christ there was no recognition for the preaching ministry of Violet Callanan.

\section{Dressing the Part}

Press reports on women preachers reveal that, in Protestant churches where women preachers were watched as often as they were heard, dress and denominational reception of visual culture mattered in the authorisation of women's ministry. The Salvation Army used its press and the richly visual imaginative world of Salvation soldiery to redefine femininity in fighting terms. The putting on of a Salvation Army uniform

69 Australian Christian, 17 May 1934.

70 Tabbernee, 'Women and Pastoral Ministry in Churches of Christ', 3.

71 'Visit of Sister Violet', Christian Echo (Queensland Churches of Christ), May 1937, 4.

72 For example, Lucy Chesser, "Woman in a Suit of Male": Sexuality, Race and the Woman Worker in Male "Disguise"', 1890-1920', Australian Feminist Studies, 23, no. 56 (2008): 175-94, doi.org/10.1080/08164640701576074; Valerie Smith, 'Class and Gender in Narratives of Passing', in Feminist Consequences: Theory for the New Century, eds. Elisabeth Bronfen and Misha Kavka (New York: Columbia University Press, 2001), 189-210, doi.org/10.7312/bron11704-008. 
was a sign of conversion to a new life and a new way of being, and a valuable source of publicity for the mission-oriented denomination. Presbyterian deaconesses were clothed in respectability for work that was lowly. Inconspicuous without insignia, yet 'set apart', a blue dress signalled that Hilda Wilson's role in Queenstown remained a secondorder ministry despite her responsibilities. Women's uniforms, as part of the visual culture of these two denominations, simultaneously expanded and circumscribed the religious authority of women preachers. However, an absence of clerical robes and a prohibition on ostentation in dress effectively limited religious imagination and, with it, the visualisation of expanded roles for women. In Churches of Christ, where clothing officially played no part in ministry, Violet Callanan wore a collar and tie, then a tunic and veil. Neither brought her recognition. In a denomination that was fundamentally suspicious of visual culture, her attempts to re-style herself as a preacher of the Word were largely met with silence. Factors that favoured women's ministry-locally autonomous church governance (or a strongly supportive hierarchy), pastoral understandings of ministry, education, biblical liberalism and strong women's guilds-were not enough to enable women's ministry. Women needed the opportunity to 'appear' as a preacher and, in appearing, become a preacher. 



\title{
'Laugh and Grow Fat': Resistance, Complicity, Fat Bodies and Community Amongst Rural Women in Interwar Western Australia, 1934-1939
}

Jessie Matheson

University of Melbourne

\begin{abstract}
In 1934 rural Western Australian women began writing letters into the women's pages of the Western Mail. These letter writers quickly formed a community-the self-proclaimed 'Virgilians' of 'Virgilians' Friendly Corner'. The letters of 'The Corner' suggest new avenues for the ways in which public womenonly spaces can be understood, particularly in contexts that are coded as conservative. In its study of the fat women who made up a significant portion of the Virgilian community, this article finds that the social and cultural conditions of 'Virgilians' Friendly Corner' allowed these women to create a space to share their experiences of their non-conforming bodies. These stories often resisted, but would also sometimes reinforce, dominant cultural narratives about their bodies. This demonstrates the ways in which these kinds of women-only public spaces do not fit comfortably into traditional radical/conservative binaries, suggesting that they should be redefined by this ambivalence.
\end{abstract}

1 My thanks to Joy Damousi and Mary Tomsic who offered invaluable advice on early drafts of this article. This research was undertaken during my $\mathrm{PhD}$ candidature at the University of Melbourne, in partnership with Museums Victoria as part of the 'The Invisible Farmer Project' (ARC Linkage LP160100555). Thanks also to the two anonymous referees for their helpful feedback. Teach 'Em, 'Laugh and Grow Fat!', Western Mail, 13 June 1935. 
On a cool, sunny autumn day in 1935 in the Western Australian wheatbelt, a woman who went by the penname of 'Wheat Ears' wrote into the women's pages of the Western Mail. She was fantasising about meeting the editor of the pages, 'Virgilia'. The trip to Perth would be difficult for her, she reasoned - she was 'outsized' and dreaded the hostile looks she received when moving through busy public spaces and on public transport. It made her 'blue' just to think of it. She wrote her thoughts in a public letter, addressed to 'Virgilia' and her fellow readers. If she ever did visit, she joked, '[you] couldn't miss me even if you wanted to, there is so much of me!'2 Yet the experiences of 'outsized', or fat, women like 'Wheat Ears' have often been missed by historians.

In 1934 rural Western Australian women, mostly white farming women, began writing letters into the women's pages of the Western Mail in what became known as 'Virgilians' Friendly Corner'. 'The Corner' was enthusiastically adopted and soon became a fixture in the newspaper, with a community of dedicated contributors, many of whom wrote in for decades. 'Wheat Ears' was one of the first women to write regularly to 'The Corner'; many readers wrote back to applaud her recipes, her poetic reflections on life on the wheatbelt, and, significantly, what they termed her 'laugh and grow fat' mentality. ${ }^{3}$ Soon other women began sharing their experiences of their fat bodies in public spaces and their own ideas about what it meant to be a fat woman. In doing so, these women both resisted and perpetuated many of the dominant cultural narratives of conforming femininity that governed Australian cultural ideals throughout the interwar period. As a public space that was coded as an extension of the private home, and as an overwhelmingly conservative space that accommodated many radical ideas, 'The Corner' undermines assumptive public/private and conservative/radical binaries. This article will explore 'The Corner' as a space where women both resisted and sometimes reinforced popular (mis)conceptions about women's bodiesin particular, fat bodies.

In its early years 'The Corner' became a space where women with large bodies began to share their experiences. Usually identifying themselves as 'O.S.' (outsized), these women used 'The Corner' to reflect on their common experiences as 'O.S.' women. They often would air their dismay and disillusionment with the disjuncture between dominant cultural narratives

2 Wheat Ears, 'The Virgilian', Western Mail, 4 April 1935.

3 Zora, 'Camp Life', Western Mail, 4 July 1935. 
about women whose body size fell outside of the arbitrary ideal and what they knew about their own non-conforming bodies. Others, like 'Wheat Ears', found joy and humour in their bodies and used their space in 'The Corner' to express this. By undertaking a detailed textual analysis of the letters of these women and how they responded to this perceived disjuncture, this article suggests that the 'O.S.'-identifying women of 'The Corner' should be incorporated into a 'pre-history' of the 'fat activist' movements that began in the early 1970s. ${ }^{4}$ It analyses three key letters, which formed part of a much larger, vibrant world of 'O.S.' women sharing their experiences. By taking a look at how women experienced and responded to dominant interwar discourses of the fat body, this article suggests that histories of fat, resisting bodies must go beyond studying sites of explicit resistance and incorporate what Jennifer Jones refers to as a 'quiet form of activism'sites of personal resistance and community solidarity. 'The 'O.S.' women of 'The Corner' offer a rare insight into how popular discourse surrounding fat bodies was experienced by people with these bodies. It also represents the quiet resistance to these discourses that preceded movements of explicit fat activism, modern identity politics, and body positivity rhetoric.

\section{Finding Rural Australia in Fat History}

Interdisciplinary fat studies has been growing steadily since 2004, when early conferences in the field were first held in the United States. ${ }^{6}$ However, these studies have been largely based in the social sciences. Histories of fatness have been less pervasive and tend to situate themselves in four categories. First, there are those studies that theorise 'obesity' as a rising social problem of which contemporary culture is the pinnacle or take a pitying look at fat-bodied people. ${ }^{7}$ Second are activist histories of early fat liberation movements such as The Fat Underground. ${ }^{8}$ Third are histories

\footnotetext{
4 Nina Mackert and Jürgen Martschukat, 'Introduction: Fat Agency', eds. Nina Mackert and Jürgen Martschukat, Body Politics, 5, no. 3 (2015): 10.

5 Jennifer Jones, Country Women and the Colour Bar: Grassroots Activism and the Country Women's Association (Canberra: Aboriginal Studies Press, 2015), xi.

6 Marilyn Wann, 'Fat Studies: An Invitation to Revolution', in The Fat Studies Reader, eds. Esther D Rothblum and Sondra Solovay (New York: NYU Press, 2009), xi, doi. org/10.1177/0959353510396340.

7 For example, see Georges Vigarello, The Metamorphoses of Fat: A History of Obesity, trans. C Jon Delogu (New York: Columbia University Press, 2013), doi.org/10.1080/21604851.2015.1041332.

8 For example, see Sondra Solovay and Esther Rothblum, 'Introduction', in The Fat Studies Reader, eds. Sondra Solovay and Esther Rothblum (New York: NYU Press, 2009), 4, doi. org/10.1177/0959353510396340.
} 
of fat oppression, such as those of dieting or of commercialised beauty. ${ }^{9}$ Finally, there are those studies that seek to locate different attitudes to fatness across time, thus exposing the ways in which contemporary notions of 'fat', 'obesity' and 'health' are culturally contingent and undermining an assumption that there is a naturalness to fat stigma or an ideal 'healthy' body. ${ }^{10}$ While fitting most comfortably with the latter categories, this article takes a different approach. It suggests that resistance/ oppression dichotomies do not reflect the embodied experiences of fat people, particularly women. ${ }^{11}$ It also suggests that within cultures of fat stigma, women find creative (and often covert) languages of resistance, yet may also be complicit in the perpetuation of that which seeks to oppress their bodily autonomy. Elena Levy-Navarro has termed this approach a 'fattening' of history-locating sites of joy and exuberance in histories of fat people, which may 'sustain' modern scholarship. ${ }^{12}$ There is something inherently linked to queer theory in this stance; as a study of non-conforming bodies and of questions of assimilation, a fat history suggests challenging the natural state of idealised thinness or notions of 'normal' body sizes. ${ }^{13}$ Much as heterosexuality and history are rendered indistinguishable from one another by the former's supposed naturalness (as Eve Sedgwick has suggested), 'average-sized' bodies represent a central assumption of most histories. ${ }^{14}$ Levy-Navarro proposes that fat histories should both challenge the unnaturalness of the fat body and offer new ways toward exploring relationships with bodies. ${ }^{15}$

9 For example, see Hillel Schwartz, Never Satisfied: A Cultural History of Diets, Fantasies and Fat (New York: The Free Press, 1986).

10 For example, see Laura Fraser, 'The Inner Corset: A Brief History of Fat in the United States', in The Fat Studies Reader, eds. Esther Rothblum and Sondra Solovay (New York: NYU Press, 2009), 1114, doi.org/10.1177/0959353510396340; or the recent uncomfortable work on the pre-history of anti-fat attitudes: Christopher E Forth, Fat: A Cultural History of the Stuff of Life (London: Reaktion Books, 2019).

11 Elena Levy-Navarro, 'Fattening Queer History: Where Does Fat History Go From Here?', in The Fat Studies Reader, eds. Esther Rothblum and Sondra Solovay (New York: NYU Press, 2009), 20, doi.org/10.1177/0959353510396340. This includes discussion of early modern poet Ben Jonson and is a good example of this approach.

12 Ibid., 15.

13 Indeed, histories of fat liberation and queer politics are also entwined. See Zora Simic, 'Fat as a Feminist Issue: A History', in Fat Sex: New Directions in Theory and Activism, eds. Caroline Walters, Helen Hester, and Meredith Jones (Farnham: Ashgate Publishing, 2015), 15-37, doi.org/10.1080/2 1604851.2016.1094979.

14 Eve Sedgwick in Levy-Navarro, 'Fattening Queer History', 17.

15 Ibid., 17. 
Little work has been done on fat resistance that precedes the explicit 'fat activist' movements of the late twentieth century. Very little work has been done on the history of Australian women's fat bodies. ${ }^{16}$ Histories of 'fat activism', in its various forms, must find ways to look beyond explicit languages of resistance. ${ }^{17}$ This article will explore the ways in which more covert, and therefore more ambivalent, communities of women developed around strikingly similar principles to fat liberation movements of sharing their experiences and their stories about their bodies. It stresses the contingency of fat experiences by centring on the ways in which Western Australian interwar culture, and the physical characteristics of a large and profoundly isolated state, influenced women's bodily experiences. These communities were not coded as radical, but nevertheless implicitly questioned hegemonic and patriarchal assumptions about idealised femininity.

'Fat' is not a universal experience; discourses of fat stigma vary more significantly than is often presumed and are reflections of particular cultural conditions. The letters to 'The Corner' on which this article focuses are an expression of the very specific cultural context of interwar Western Australia, which, in many respects, was contending with its status as a newly established (white) 'frontier' and with oncoming waves of modernity and migration. ${ }^{18}$ The dominant historiographical question of Western Australia is, arguably, the extent to which 'consensus' can be understood as the primary ideological goal of Western Australians in the interwar period. ${ }^{19}$ Geoffrey Bolton argues that the particular cultural context of Western Australia as a highly isolated part of Australia and the British Empire led to a situation whereby solidarity, or 'consensus', was prioritised over any discussion of division or tension. While, he argued, this created a situation whereby the dominant ideological position was

16 Australian fat theorists have made significant contributions to transnational approaches to fat studies. Simic's 'Fat as a Feminist Issue: A History' is a good example of transnational approaches to histories of fat activism. Samantha Murray's The 'Fat' Female Body (Basingstoke, Hampshire: Palgrave Macmillan UK, 2008) on contemporary fat female embodiment has significant implications for fat histories.

17 Samantha Murray discusses this in the contemporary context. See Samantha Murray, '(Un/Be) Coming out? Rethinking Fat Politics', Social Semiotics, 15, no. 2 (2005): 153-63, doi. org/10.1080/10350330500154667.

18 An exemplar of this cultural shift is the post-war group settlement schemes. For greater discussion on this, see Mark Brayshay and John Selwood, 'Dreams, Propaganda and Harsh Realities: Landscapes of Group Settlement in the Forest Districts of Western Australia in the 1920s', Landscape Research, 27, no. 1 (2002): 81-101, doi.org/10.1080/01426390220110784.

19 Geoffrey Bolton, A Fine Country to Starve In, 2nd ed. (Nedlands: University of Western Australia Press, 1994), xviii. 
unusually accommodating to different views and experiences, particularly in terms of issues relating to class, it also led to a more extreme ostracisation of anyone who resisted these assimilative practices or was perceived as disruptive. ${ }^{20}$ While some historians have challenged this consensus theory, my study of letters to 'The Corner' finds they were likely an expression of this idiosyncratic type of in-group. ${ }^{21}$ They demonstrated both the flexibility and the conservativism Bolton describes. Virgilians fashioned themselves as a welcoming group that encouraged debate; however, the responses to more radical letters both from 'Virgilia' and from other contributors suggest that women who did not conform were alienated. This particular consensus culture created conditions where more expansive discussions about non-conforming bodies could, at least partially, thrive.

'The Corner' is both an illustration of the unique cultural context of Western Australia in this period and of how women on the land, Australia-wide, experienced global and local pressures. It is an example of the kinds of communities many rural women constructed in response to these various pressures. Letters to 'The Corner' are also a reflection of a culture of rural press that was developing across Australia and, in particular, of women's pages within these newspapers, which were offering new spaces for women on the land to express their experiences. They also add to a study of the ways in which anxieties surrounding the health of Empire was reflected on anxieties over fattening bodies. ${ }^{22}$ Studies of this very particular moment of transition, in which Western Australia was contending with post-war modernisation, may be informed by studies of fatness, as anxiety over fatness is often tied to anxieties over moments of transition and pressure where discourses of morality, consumption and cohesion thrive. ${ }^{23}$

21 For discussion of the reaction against the consensus theory, see Jenny Gregory, 'Western Australia Between the Wars: The Consensus Myth', Studies in Western Australian History, 11 (1990): 1-16.

22 Elena Levy-Navarro, 'Changing Conceptions of the Fat Body in Western History', in Historicising Fat in Anglo-American Culture, ed. Elena Levy-Navarro (Columbus: Ohio State University, 2010), 2, doi.org/10.3366/soma.2012.0069.

23 Ibid. 


\section{The Western Mail and the Women's Pages}

In July 1934 a young Mary Durack took her first paid writing assignment as 'Virgilia', the conductor of 'Women's World', the women's section of the Western Mail. ${ }^{24}$ Durack went on to become a prominent writer and historian, and as a member of one of Western Australia's oldest farming families she was aligned strongly with the public image of the Western Mail. The newspaper was an early addition to the fledgling Western Australian newspaper and literary traditions, firmly linked to the dominant ideologies of local newspaper magnates that the future of Western Australia would be reliant on primary industries. ${ }^{25}$ Like most Western Australian newspapers in this period, it perpetuated a conservative yet optimistic vision of the future whereby 'the public and private spheres of human life merged and conformity to social norms and expectations presupposed personal happiness and material well-being. ${ }^{26}$ In this way, it distinguished itself from those publications that featured more diverse political voices and technology, such as the wireless radio that was beginning to host more varied visions of Australia's future. ${ }^{27} \mathrm{~A}$ focus on primary industries presupposed an audience of nuclear families that were tied to visions of closer settlement farming and mining. Most of the newspaper was aimed at men; the women's pages imagined their wives as the audience and had a decidedly domestic focus. Within these pages, there is little sense of the growing connections between Western Australian feminists, who were increasingly using print and radio to develop their networks across the state in this period. ${ }^{28}$

Durack's initial edition represented a fairly standard collection of recipes and beauty tips that did little to distinguish itself from other suburbanfocused women's columns. However, coupled with an opening article by 'Virgilia' on the pleasures of country life was a call: 'country women are

\footnotetext{
24 Brenda Niall, True North: The Story of Mary and Elizabeth Durack (Melbourne: Text Publishing Company, 2012), 59.

25 Ffion Murphy and Richard Nile, The Gate of Dreams: The 'Western Mail' Annuals, 1897-1955 (Fremantle: Fremantle Arts Centre Press, 1990), 13.

26 Ibid., 11.

27 Jeannine Baker, 'Woman to Woman: Australian Feminists' Embrace of Radio Broadcasting, 1930s-1950s', Australian Feminist Studies, 32, no. 93 (2017): 292-308, doi.org/10.1080/0816464 9.2017.1407643; Diane Kirkby, “"Those Knights of the Pen and Pencil”: Women Journalists and Cultural Leadership of the Women's Movement in Australia and the United States', Labour History, 104, (May 2013): 81-100, doi.org/10.5263/labourhistory.104.0081, are both good examples of the progressive public communication spaces of the interwar period, and the opportunities they represented to feminists.

28 Baker, 'Woman to Woman', 295.
} 
invited to send in short paragraphs of interesting happenings which they think will appeal to other readers'. ${ }^{29}$ At this time, the Western Mail was still one of the only forms of contact many women in remote districts had outside of their immediate families. ${ }^{30}$ 'Virgilians' Friendly Corner' hoped to reach out to a new generation of farming families, many of whom were beneficiaries of various new farm settlement schemes that were established in Western Australia during the interwar period. ${ }^{31}$ It was hoped that 'The Corner' would serve to 'foster friendships between lonely people and to provide a medium of exchange of ideas'. ${ }^{32}$ The popularity of the section soon surpassed 'Woman's World', with more and more space dedicated to 'The Corner'. Durack would publish letters from contributors, usually paired with a short response from herself. 'Virgilians' Friendly Corner' would go on to even outlive Durack's time at the paper, as the persona of 'Virgilia' was taken up by a number of different women. ${ }^{33}$ Some women wrote consistently to 'Virgilia' in 'The Corner' for decades, and a whole culture was built around self-proclaimed 'Virgilians'. Every week, backto-back pages of dozens of letters would be crammed into the little space dedicated to women in the Western Mail. Badges were distributed so fellow writers could identify one another, parties were held where Virgilians could meet, advice and services were swapped, and, most often, stories of lives, mostly in rural and remote Western Australia, were shared. ${ }^{34}$

\section{Identifying a Fat Positive Space}

To an uninitiated reader, 'The Corner' does not appear to discuss weight or fatness. The language of body size is usually coded, with contributors almost uniformly applying the widely popular euphemism 'O.S.' or 'X.O.S.' to indicate they identified as 'outsized'. Fat studies scholars have heavily critiqued the use of euphemisms to describe fatness; Marilyn Wann, for example, has suggested that 'you only need a euphemism if you find the truth distasteful'. ${ }^{35}$ The designation 'outsized' is rendered doubly problematic,

\footnotetext{
29 Virgilia, 'Virgilia', Western Mail, 5 July 1934.

30 Ibid., 24; Niall, True North, 15.

31 Virgilia, 'How the Friendly Corner Began, and Grew', Western Mail, 2 September 1954.

32 Ibid.

33 The penname 'Virgilia' was said to be a derivation of 'Virgil' who they believed captured the spirit of the endeavour. See Virgilia, 'How the Friendly Corner Began, and Grew'.

34 'Virgilian Badges', Western Mail, 28 January 1983.

35 Marilyn Wann in Johnanna J Ganz, “The Bigger, the Better”: Challenges in Portraying a Positive Fat Character in Weeds', Fat Studies, 1, no. 2 (2012): 215, doi.org/10.1080/21604851.2012.651613.
} 
as it gestures towards the existence of one appropriately normal size from which fat people are excluded. ${ }^{36}$ Yet, in the world of Virgilians, there is little sense that to be 'O.S.' is distasteful, as women spoke openly and comfortably about their size. ${ }^{37}$ Indeed, to be critical of these euphemisms for 'fat' would obscure the extent to which 'The Corner' was a world of code and euphemisms. Most contributors to 'Virgilians' Friendly Corner' used pennames, as was customary (but not compulsory) for public letter writing. Sarah Pederson, working with Scottish women's letters to the editor, has argued that in the early twentieth century the use of pseudonyms in newspapers allowed women to construct a civic identity and, by stressing their femininity in their chosen names, extended their private spaces into public discourse. ${ }^{38}$ While the policy of using pennames was initially introduced to combat shyness from contributors, the recurring nature of letters to 'The Corner' enhanced the process Pederson describes, and names were often chosen to reflect a public identity. ${ }^{39}$ Contributors from the Western Australian wheatbelt, for example, often went by names such as 'Wheat Ears' and 'Wild Oats'; (the few) male contributors often chose names that reflected their constructions of masculinity such as 'Viking' and 'Ladies' Man'. ${ }^{40}$ Most popular was the construction of an identity in relation to family, such as 'Bush Mother', 'Digger's Wife', and 'Mater Familias'. ${ }^{41}$

The diversity of these chosen names reflected the disparate goals of the letter writers and highlights how conscious this mode of identity construction was. For the Virgilians, their pennames performed much the same goal as the letters themselves, as they represented a creative opportunity where women were empowered to define themselves in relation to their values. Ironically, the obscuring of identities became an expression of both individualism and literacy in the shared practices of the Virgilian community. As such, the use of euphemisms such as 'O.S.' should be considered in the same terms - as something coded in privacy, respectability and even safety, yet was in reality a feature of a consciously cultivated in-group who shared both language and community, and, importantly, tied their fatness to their civic identity. Much like the

36 Esther D Rothblum, 'Why a Journal on Fat Studies?', Fat Studies, 1, no. 1 (2012): 4.

37 Teach 'Em, 'Laugh and Grow Fat!'

38 Sarah Pedersen, 'What's in a Name? The Revealing Use of Noms de Plume in Women's Correspondence to Daily Newspapers in Edwardian Scotland', Media History, 10, no. 3 (2004): 184, doi.org/10.1080/1368880042000311537.

39 Virgilia, 'How the Friendly Corner Began, and Grew'.

40 Old Pickle, 'Noble First Hundred!', Western Mail, 13 January 1938.

41 Ibid. 
feminist publications of the early twentieth century, 'The Corner' was creating a community of women, but one defined by safety and even the illusion of conformity. This here is the ambiguous space of women letter writers: the pages were, in many ways, radical in their support of women and the space it created for women who identified as 'O.S.' to share their experience, yet by obscuring their discussion in euphemism, this radicalism is tempered by more conservative questions of respectability. These spaces should be considered within a history of resistance as neither comfortably conservative or radical, but rather-as Jones identifies in a different community of rural women - as a 'quiet form of activism' often associated with women's use of their power and space to achieve progress and reform or, at least, to create safer communities. ${ }^{42}$ The community created by Virgilians expands the history of fat activism and suggests that fat positivity can be located in a wide variety of communities that, whilst not explicitly political, were creating spaces for fat women to share their experiences and resist discourses that sought to undermine and alienate them.

\section{'Nil Desperandum' on the Medical Establishment, Women's Work and Fat Women}

In 1936 'Nil Desperandum', a woman from a sheep farm in the central wheatbelt region, wrote to 'The Corner' asking: 'As most of the Virgilians seem to be "O.S.", I wonder what they will say when I tell them that a Harley-street specialist says that most of the "O.S." women of today are the arm-chair type'. ${ }^{43}$ 'Nil Desperandum' clearly established this dichotomy between Virgilians (whom she significantly identifies as mostly 'O.S.') and medical doctors, before responding to herself: 'If I had him here for a week, I bet he would eat his words. ${ }^{34}$ These ideas were not coded as radical, yet within 'The Corner', which had comfortably encoded itself as the prescriptive social space of the majority, women such as 'Nil Desperandum' had begun expressing the ways in which the standards of morality and health of which rural women were often made icons were not only untrue, but were limiting and hurting them.

42 Jones, Country Women and the Colour Bar, xi.

43 Nil Desperandum, 'Cheap Ice', Western Mail, 30 July 1936.

44 Ibid. 
The medicalisation of the rural ideal became a focus around which some Virgilians framed their critique of fat-shaming and embraced their own healthy 'O.S.' bodies. 'The Corner' was a space in which women resisted these discourses. They shared their experiences and their frustration with the disparity between what doctors told them about their bodies and what they knew about their lives and lifestyles. Many histories of fat have found that cultural attitudes around fatness as signifier of laziness and lack of control preceded and informed the slow move of the medical establishment toward habitual weighing and recommending weight-loss to patients, a practice that was firmly established by the $1960 \mathrm{~s} .{ }^{45}$ While loss of weight was associated with a number of 'wasting' diseases such as tuberculosis in the late nineteenth century, the early twentieth century was a period in which doctors were attempting to discern if weight gain was also a sign of un-healthiness or simply an inevitable part of the ageing process. ${ }^{46}$ The early decades of the twentieth century may be characterised by an ambiguity over the extent to which fatness and poor health were linked. This confusion over what weight gain, or fatness, signified in medical terms was dramatised in public discussions surrounding fatness. Many women viewed dieting as a dangerous and unhealthy fad, and confusion over these increasingly mixed messages were played out in spaces such as 'The Corner'. ${ }^{47}$ The Western Mail is a typical example of this disjuncture, as while in the women's pages women were encouraging one another to simply 'laugh and grow fat', in other sections of the same newspaper doctors sternly warned 'Laugh and Grow Fat: But Length of Life is Diminished'. ${ }^{48}$

In his study of diet cultures in the United States, Hillel Schwartz argued that Depression conditions led to a general valorisation of 'reduction', which was embodied by weight-loss narratives. Weight-loss and frugality coalesced in a newly moralised economic culture. ${ }^{49}$ Diet pills—some of which contained toxins found in wartime-era explosives-flooded the market; meanwhile, there were growing discourses that stated only 'natural' foods could be considered healthy..$^{50}$ Psychologists also participated in this boom,

45 Amy Farrell, Fat Shame: Stigma and the Fat Body in American Culture (New York: NYU Press, 2011), 34-5, doi.org/10.1080/21604851.2012.629138.

46 Ibid.

47 Wheat Ears, 'The Virgilian'.

48 Teach 'Em, 'Laugh and Grow Fat!'; 'Laugh and Grow Fat: But Length of Life Is Diminished',

Western Mail, 9 May 1940.

49 Schwartz, Never Satisfied, 192.

50 Ibid., 191. 
pathologising fatness as an expression of mental anguish, associated with lethargy, anxiety and depression-a kind of mindless consumption to satiate more substantial emotional shortfalls. ${ }^{51}$ This coincided with the rise of Western psychoanalytic approaches to questions of 'fat'. ${ }^{2}$ Discussions of weight became increasingly gendered, whereby fatness in women and men began to take on important distinctions. ${ }^{53}$ The new sexual cultures of the interwar period also influenced medicalised misunderstandings of fat. In Western Australia, much as in the rest of Australia, new connections between healthy conforming sexuality and healthy conforming bodies developed. ${ }^{54}$ Consumerism, moralism and the medical industry met in this period to create a tangle of messages, which resulted in the resounding sense that fat women were responsible for their fatness, and that fat was a medical problem that could, and therefore should, be solved.

'Nil Desperandum' paired her critique of the medical establishment with a comment on women's work, concluding:

I have an acre of garden to look after, and I grow all the vegetables for the house, bake 16 loaves of bread a week, do all the other cooking, and keep a six-room house clean; two children to look after, and one to teach, and 100 fowls to care for. So you can imagine how much arm-chair I enjoy. And at present, I have a nice bundle of sewing and darning waiting on the machine ... Last week I made dozens of jars of pickles and chutneys, as the frost killed the tomato bushes ... The garden party frock competition sounds very nice, but, alas, I will be missing again this year, as we are shearing a month later this year, and, as usual, the cook's job falls to me. ${ }^{55}$

Discourse on the health and bodies of rural women often centred around notions of farm work. Kathryn Hunter has described at length the evocative debates undertaken in the Victorian rural newspaper the Farmers' Advocate surrounding the work of women on family farms. She describes a generational divide between those holding pronatalist fears of physical labour unsexing women and risking their reproductive capabilities and (usually) younger women, who appealed to images of hardy and healthy

51 Ibid., 194.

52 Sander Gilman, Fat: A Cultural History of Obesity (Cambridge: Polity, 2008), 191-4.

53 Peter N Stearns, Fat History: Bodies and Beauty in the Modern West (New York: NYU Press, 1997),

74, doi.org/10.1086/ahr/104.4.1325.

54 Richard Nile, 'Eroticism, Sex and the Politics of Imagination', Studies in Western Australian History, no. 11 (1990): 120.

55 Nil Desperandum, 'Cheap Ice'. 
Australian girlhood to advocate for their right to work on the land. ${ }^{56}$ Both these positions drew upon the contradictory medical discourses of the period, and when placed in conversation reveal the disparity between these cultural ideals of rural womanhood and the realities of women's labour on farms. Kate Darian-Smith and Sara Wills have discussed how during the interwar years the institution of the 'Show Queen' was utilised to mask the productive work women did in rural communities, emphasising their symbolic role as signifiers of passive femininity. ${ }^{57}$ Emphasis on women being needed or active, Darian-Smith and Wills argue, threatened to emasculate men, whose own gender identities had been made vulnerable by rural downturn. ${ }^{58}$

'Nil Desperandum' clearly defines herself here by her work, which she talks about openly and frankly. This is an example of the power Virgilians claimed by extending the private sphere of their homes into the pages of a newspaper. She seems to believe that the medicalisation of her body is predicated on the invisibility of her work and counters this by exposing the constant work of women on farms. I argue that by stressing their work, indeed, their over-work, in response to cultural assumptions about their weight, Virgilians were attacking the rural ideal of passive femininity that Darian-Smith and Wills describe, threatening to expose the myth that work and gender had ever represented a neat dichotomy in rural life, as the media and dominant cultural ideals suggested.

\section{'Nota Bene' on the Male Gaze}

'Nil Desperandum's' letter elicited a number of responses, particularly from farm women who likewise rejected the assumption that there was a connection between their 'O.S.' bodies and their (perceived lack of) work. 'Nota Bene's' response to 'Nil Desperandum' contrasted the medicalisation of women's bodies with their sexualisation and identified the ways in which the sexualised and the dismissive or ridiculing gazes came from the same presumptive authority to look:

56 Kathryn M Hunter, 'The Drover's Wife and the Drover's Daughter: Histories of Single Farming Women and Debates in Australian Historiography', Rural History, 12, no. 2 (2001): 191, doi. org/10.1017/s0956793300002430.

57 Kate Darian-Smith and Sara Wills, 'From Queen of Agriculture to Miss Showgirl: Embodying Rurality in Twentieth-century Australia', Journal of Australian Studies, 25, no. 71 (2001): 19, doi. org/10.1080/14443050109387717.

58 Ibid. 
I second "Nil-Desperandum's" remarks re "O.S." figures and armchairs ... I have gained weight when I have not had time to even think of an arm-chair, let alone sit in one. But, why worry? In my youthful days I had a figure that looked like an imaginary line drawn through a princess frock, and one kind (?) neighbour said I looked like two boards tacked together! Now, after twenty-odd years, that same, neighbour views my Mae West curves with a pitying "Ain't she fat" sort of expression. So you see there is no pleasing ' $\mathrm{em}$ !

The letters of Virgilians show the ways in which institutional discourse and localised experience were linked. They are a comment on the multiple fronts upon which myths such as the link between fatness and laziness or low self-discipline are perpetuated. ${ }^{60}$ They also implicitly suggest the ways in which this was a particularly gendered process linked to the qualities women were expected to display, such as submissiveness to control and surveillance of their bodies. ${ }^{61}$ The media has consistently played a crucial role in endorsing and perpetuating both the institutional and local surveillance and sexualisation of women's bodies, fostering the connections between the moralities of indulgence and transgression with women's eating. ${ }^{62}$ In spaces such these, women reclaimed print media spaces, rejecting this myth of connections between fatness and laziness with personal narratives of their own active lives of work and movement.

This article has consciously not focused on men and their perspective on fatness in public spaces. It is significant that one of the few times weight was discussed in negative or aesthetic terms in this period was by a male Virgilian, 'Viking', who suggested that if 'Virgilia' told her male readers she was 'X.O.S.' she would 'pour cold water on most of our fond imaginings' ${ }^{63}$ No male Virgilians identified themselves as 'O.S.'. Male Virgilians were a minority in 'The Corner', which practically functioned as a women-only space. The ways in which individual men used fat jokes to encroach on this women-dominated space is not the focus of this

59 Nota Bene, 'A Matter of Form', Western Mail, 24 September 1936.

60 Ganz, “"The Bigger, the Better”, 210.

61 Ibid.

62 Susan Bordo, Unbearable Weight: Feminsim, Western Culture, and the Body (Berkeley: University of California Press, 2003), 112.

63 Viking, 'Blame "Virgilia”, Western Mail, 13 June 1935. 
discussion of solidarity among women. However, it should be noted that the experience of fat men has frequently collided with aesthetic notions of hegemonic masculinity, and this is a fruitful area for further research. ${ }^{64}$

'Nota Bene's' comment on her neighbour and objectification is an example of the ways in which Virgilian women used 'The Corner' as a space in which they could express experiences of the male gaze and how this gaze changed the way they experienced space. The letters of the Virgilians are an archive of the ways in which women created communities and resisted discourses imposed upon them. Virgilian women spoke openly and comfortably about their size, suggesting that 'The Corner' was a personal, safe community. However, their stories also represented how this category was imposed upon them; narratives of discrimination and ridicule were shared, and many women expressed anxiety about interactions with men in public spaces, which were determined by their size. ${ }^{65}$ The experience of Virgilian women who identified as 'O.S.' reveals a larger point about rural women and the male gaze. The resigned way in which these women reported being looked upon is contrasted with the freedom and relief they convey in sharing their stories. It suggests that popular discourses about rural life had implicitly endorsed the right of the public to assess rural women's bodies, yet that women were seeking their own ways to resist this. Virgilians' letters about their weight reveal the multiple focalisations of the male gaze, from the institutional to the personal. Yet, they also suggest multiple sites of resistance, including those like 'Nil Desperandum' who explicitly resisted these narratives about fat bodies, to more subtle forms of resistance whereby, through sharing their fear and their anxiety, women created a community of support.

'The Corner' offers a valuable insight into how patriarchy and the male gaze were experienced and resisted by rural women. Throughout the interwar period, rural women were subjected to discourses regarding what constituted healthy modern womanhood. In the face of the ever-growing influence of the cities, the supposed moral health of the country was inscribed onto the physical health of rural women's bodies. In her chapter on the 'embellishment' of rural life, Kate Murphy describes the ways

64 Bethany Phillips-Peddlesden, “'A Stronger Man and a More Virile Character”: Australian Prime Ministers, Embodied Manhood and Political Authority in the Early Twentieth Century', Australian Historical Studies, 48, no. 4 (2017): 502-18, doi.org/10.1080/1031461x.2017.1323932. This is an example of recent exciting work in this area.

65 Climber, 'Suggestion for Beach Authorities', Western Mail, 27 February 1936; Frolic, 'Why Not Women Porters?', Western Mail, 21 July 1938. 
in which the interwar period incorporated a specific type of femininity into the notion of a rural ideal. ${ }^{66}$ In response to the moral panic over the disproportionate growth of Australian cities and (supposedly linked) declining birth rates, rural women began to be held up as icons of natural femininity. ${ }^{67}$ As women who were both close to nature and closely linked to their homes, they were a site upon which the contradictions of panics over cities and the increasing pressure upon women to conform to domestic consumerism could be reconciled. For women like 'Nota Bene' and 'Nil Desperandum', this was experienced locally, publicly and, increasingly, in medicalised discourse.

\section{'Climber' and the Ambiguity of 'The Corner'}

The letters of 'Climber', from the mid-western beach town of Geraldton, suggest the ways in which Virgilians could be both responsible for the creation of a community of radical acceptance and complicit in the othering of non-conforming bodies. She writes:

Do you know, 'Virgilia,' if ever I get a seat among the Councillors or other Powers-That-Be, I'm going to do my best to have a portion of every beach reserved for O.S. and X.O.S. bathers. (Did I hear a hearty 'Hear, Hear'?) We love bathing just as much as our slim sisters - and need the exercise far more; but by the time one has procured a suitable costume, and braved the giggles of sundry small boys and girls, and tried to preserve one's dignity under a storm of remarks about tidal-waves, playful porpoises, etc., well! I ask you ... wouldn't you find the bath tub more enjoyable?

Amy Farrell has found that between 1910 and 1940 there was a distinct shift in the nature and focus of jokes about fat women in the United States. ${ }^{69}$ Increasingly tied to narratives of excess and women out of control, Farrell explores the ways in which jokes about women's bodies can be read

66 Kate Murphy, 'Rural Womanhood and the "Embellishment" of Rural Life in Urban Australia', in Struggle Country: The Rural Ideal in Twenieth Century Australia, eds. Graeme Davison and Marc Brodie (Melbourne: Monash University ePress, 2005), 4.

67 Ibid., 11.

68 Ellipses in original. Climber, 'Suggestion for Beach Authorities'.

69 Amy Farrell, "The White Man's Burden": Female Sexuality, Tourist Postcards, and the Place of the Fat Woman in Early 20th-Century US Culture', in The Fat Studies Reader, eds. Esther D Rothblum and Sondra Solovay (New York: NYU Press, 2009), 256, doi.org/10.1177/0959353510396340. 
as a combative response to the increased political and geographic freedom women were enjoying in this period. ${ }^{70}$ Jokes about women's bodies were used as a way to reinforce control over public space. Farrell studies picture postcards from this period, illustrated with images mocking fat women. The beach was a popular scene for these postcards as an icon of middleclass leisure culture. While Farrell's sample of postcards is an example of the ways in which fat jokes were made, 'Climber's' letter to 'Virgilia' is something rarer-a record of how these jokes were experienced. Farrell identified numerous jokes about porpoises and tidal waves in her study of these postcards. 'Climber's' letter shows us that these jokes were experienced as an attack on women's capacity for feeling dignity and joy in public spaces. We also see Farrell's contention that the broader tacit goal of these jokes was to revoke women's newly gained freedom in public space, as 'Climber' sees removal from, or segregation of, shared public spaces as the only possible way forward. ${ }^{71}$

This article has highlighted some examples of the significant number of women who used 'The Corner' as a space where they could resist dominant discourses of fat stigmatisation. However, a question must be raised about the complicity of women in this rhetoric. In contrast to the radically affirming letters of 'Nota Bene' and 'Nil-Desperandum', 'Climber's' letter is also a reminder of the ability of prescriptive literature such as women's pages to reinforce conformity to conservative understandings of femininity and acceptable womanhood. ${ }^{72}$ 'Climber' does not challenge the assumption that 'O.S.' women simply need more exercise, and while she highlights some structural problems that attack women's ability to use public spaces, she ultimately concludes that leaving these spaces is the most appropriate form of action. 'Climber's' letter highlights the ambivalence of 'The Corner' as a space of empowerment. She, like other 'O.S.' letter writers, claimed a community and described her experiences with a radical honesty, but the veneer of respectability of the women's pages also gave space for women to reinforce, rather than challenge, the structural barriers that attacked their use of public space. The Virgilians do not necessarily fit comfortably into histories of fat activism, nor do they distinguish themselves as a community of radical or progressive feminists.

70 Ibid., 261.

71 Ibid., 258.

72 Joanne Scott, 'Dear Editor: Women and Their Magazines in Interwar Australia', Journal of Australian Studies, 22, no. 58 (1998): 79, doi.org/10.1080/14443059809387404. 
However, the conservative coding of their letters, which obscures the many areas of solidarity Virgilians share with such fat activists and feminists, suggests a way forward in complicating both these histories.

As, at least superficially, a conservative-coded space, it is significant to note that Virgilians were also complicit in replicating many of the repressive and narrow conditions associated with their particular cultural context. Kay Whitehead has written on the profound class stratification and racial segregation of rural Western Australia in this period. ${ }^{73}$ While the Virgilians seem remarkably comfortable conversing across class lines-indeed, many of the most prominent contributors were often writing from profound poverty - the letters overwhelmingly reinforced white middle-class social ideals. ${ }^{74}$ Women worst affected by Depression conditions were praised for their ability to re-create these ideals, often in situations of near-homelessness, while women of colour were, with a small number of notable exceptions, not represented at all. 'Chrysanthemum' from the northern coastal town of Broome was one of these exceptions. When, in 1939, she wrote into 'The Corner' for the first time, she was excited as she had been a reader of the Western Mail since childhood and an admirer of 'The Corner' from afar for some time. However, she expressed a nervousness: 'I hope there is no colour bar. I am Japanese. 75 'Chrysanthemum' was largely welcomed into 'The Corner', through a slightly awkward interaction with 'Virgilia' herself, who professed a love for 'the land of the Cherry Blossoms' and reinforced the cultural homogeneity of the space by assuring her 'there is no colour bar among Christians'. ${ }^{76}$ 'Chrysanthemum's' uncertainty that she would even be allowed to contribute her perspective is indicative of the presumptive whiteness of the space.

73 Kay Whitehead, 'Marjorie Caw's Transitions from City Teacher to Leading Citizen in Interwar Rural Western Australia', History Australia, 15, no. 2 (2018): 7-10, doi.org/10.1080/14490854.201 8.1452158 .

74 Fair Fat and Firty, 'Women Are Pioneers Today', Western Mail, 25 April 1935 is an excellent example of this wider trend; 'The Corner' appealed to readers across class divides, in a way more leftist women's publications often struggled to achieve. See Kirkby, “Those Knights of the Pen and Pencil”, 89.

75 Chrysanthemum, 'A Japanese Member', Western Mail, 31 August 1939.

76 Ibid. 
Questions of race and ethnicity were a central question in rural Western Australia in this period-between 1916 and 1934 both Kalgoorlie and Broome had seen significant racially motivated riots. ${ }^{77}$ However, race and ethnicity were almost never discussed in 'The Corner', and while readers and contributors were not all white, there was little space for contributors of colour to talk about how their experience at the intersection of race, ethnicity and fatness may have been different. Further, like many white rural Western Australian women in the interwar period, Virgilians often asserted their place in an Australian national mythology by engaging with an identity of a 'pioneer' ${ }^{78}$ However, few considered the implication of their role as coloniser on Indigenous women, and I found no evidence that Indigenous women ever contributed to 'The Corner'. This can be interpreted as an expression of Bolton's theory of interwar Western Australian consensus culture, whereby difference would be welcomed, as long as it was not perceived as disruptive. It is an example of the importance of considering the cultural contingency of fat and of prescriptive women's literature. The class and racial conditions of interwar Western Australia determined whose experiences were prioritised and whose were completely ignored in this archive of fat women. Women like 'Climber' offered solidarity with other fat women, conditional on their conformity to other social ideals. Her letters have left a powerful trace of how it felt to be fat in Western Australian in the interwar period and how fat women spoke to one another. While 'The Corner' provides little explicit evidence of how race and ethnicity influenced experiences of fatness, the letters do provide insights regarding who was excluded from these rare sites of solidarity.

By the time 'Virgilians' Friendly Corner' had been established, there was a tradition of women's pages in newspapers and women's public letters to these pages. The first example of a regular women's section in Australia

77 Christine Choo, 'Inter-Ethnic Conflict in Broome, Western Australia: The Riots of 1907, 1914 and 1920 between Japanese and Other Asians', Continuum, 25, no. 4 (2011): 465-77, doi.org/10.1 080/10304312.2011.575213; John Yiannakis, 'Kalgoorlie Alchemy: Xenophobia, Patriotism and the 1916 Anti-Greek Riots', Early Days: Journal of the Western Australian Historical Society, 11, no. 2 (1996): 199-211; Sarah Gregson, "“It All Started on the Mines”? The 1934 Kalgoorlie Race Riots Revisited', Labour History, 80 (May 2001): 21-40, doi.org/10.2307/27516768.

78 Janina Trotman and Tom O'Donoghue, 'Becoming a Woman Teacher: Memories of Learning to Be a Monitor in Western Australia in the 1920s and 1930s', Oxford Review of Education, 36, no. 2 (2010): 182, doi.org/10.1080/03054981003696671; Brown Woodpecker, 'Pioneering in the South', Western Mail, 3 June 1937. 
was in the Australian Town and Country Journal, which began in $1870 .{ }^{79}$ Alice Fahs has reflected on the irony that sat at the heart of these pages, which were often at once creating a new and, by definition, radical public space for women, yet chose to, or were required to, couch these spaces in the rhetoric of domesticity. ${ }^{80}$ It is without doubt a further irony that women reported on and, as this article has shown, in many ways resisted the surveillance and control of their fat bodies in women's pages, which were perpetuating these messages of conformity. This poses a question for how women's pages should be characterised. It was a question often posed by the writers and editors of these pages themselves, who often at once required and resented their confinement to the women's pages throughout their careers. ${ }^{81} \mathrm{I}$ would suggest that the resolution to this tension between radical journalists and domestic-coded spaces can be found in a re-focalisation away from the journalists who (sometimes begrudgingly) wrote these pages onto the readers and the ways in which the content reflected their needs and wants. Letters sections such as 'The Corner' render this possible and offer insights into the expansive implications of a domestic-coded public space.

By focusing on the experience of readers, we confront the ways in which women's pages created a discursive community and a public world, yet only by extending private space. Rather than proclaiming their rights to public space, as many more radical newspaper women aimed to do, the women readers and writers who populated pages such as 'The Corner' often hedged the self-conscious creation of a highly public community in the language of the private domestic sphere. Yet, the simple act of sharing their stories and opinions in many ways implicitly questioned hegemonic discourses that devalued women's participation. Katie Holmes in her study of Australian women's diaries reconciles this conservative/radical tension by suggesting: "While writing a diary did not appear to challenge women's traditional roles as wife, mother, daughter or household manager, in doing so women accorded to these activities a status otherwise denied

79 Justine Lloyd, 'Women's Pages in Australian Print Media from the 1850s', Media International Australia, 150 (February 2014): 62, doi.org/10.1177/1329878x1415000114.

80 Alice Fahs, Out on Assignment: Newspaper Women and the Making of Modern Public Space (Chapel Hill: University of North Carolina Press, 2011), 56, doi.org/10.1080/08821127.2012.1067 7816.

81 Mary Durack may have been one of these writers with an amiguous relationship with her readers. Durack's biographer describes her as 'besieged by garrulous readers [of "The Corner"]' and left with little time for 'serious' writing. Niall, True North, 59, 63. 
them. ${ }^{82}$ By focusing on readers and their experiences of this space, it is made clear that the dichotomies of radical and conservative can serve to obscure these women who operated in and were complicit in creating much more ambiguous spaces.

Correspondence from readers was a fairly typical feature of women's pages and the new commercially focused women's magazines, which were being developed in the interwar period. ${ }^{83}$ This trend is often associated with urban newspapers and magazines, but they were also a vibrant space in rural press. ${ }^{84}$ The Weekly Times, Australia's largest rural newspaper launched their women's section, 'The Women's Bureau', in 1931, which included correspondence with 'Miranda', a persona that still exists today. ${ }^{85}$ The Victorian Farmers' Union newspaper, the Farmers' Advocate, had featured letters from its female readers from as early as $1919 .{ }^{86}$ Other women-specific magazines also published the letters of rural women, such as Woman's Budget, which aimed to 'establish a pen-and-ink bond between the bush and city dwellers' ${ }^{87}$ Raelene Frances suggests that Australian women's magazines of the interwar period reflected and enforced the socially mandated behaviours of a cultural majority, perpetuating a conservative 'gender script' that dictated women's behaviour, portrayal and self-image. ${ }^{88}$ By focusing on the letters from readers (while also acknowledging that we have little way of knowing to what degree they were mediated by an invisible editorial hand), we develop a picture of how life was experienced by this supposedly homogenous, authoritative group. We may begin to break down this group: in the case of 'The Corner', we see the ways in which these readers' experiences were determined by their rurality, the particularities of Western Australian interwar culture

82 Katie Holmes, Spaces in Her Day: Australian Women's Diaries 1920s-1930s (Sydney: Allen \& Unwin, 1995), xviii.

83 Kirkby, "'Those Knights of the Pen and Pencil”, 91.

84 Hunter, 'The Drover's Wife and the Drover's Daughter'; Ruth Ford, "I Shut My Eyes and Picture Our Place": Gardens, Farm Landscapes and Working-Class Dreams in 1930s-1940s South-Eastern Australia', Studies in the History of Gardens \& Designed Landscapes, 31, no. 2 (2011): 109-20, doi.org $/ 10.1080 / 14601176.2011 .556374$. Both of these works have used rural women's letters published in Eastern rural newspapers to draw conclusions about the experience of women on the land.

85 Ford, "I Shut My Eyes and Picture Our Place", 110.

86 It is possible that the early addition of women's letters to Farmers' Advocate is an outcome of the more political aims of the paper, which would explicitly seek the support of women voters. For example, see 'For Our Women', Farmers' Advocate, 23 October 1919.

87 Woman's Budget, 9 April 1921, 5, quoted in Scott, 'Dear Editor', 77.

88 Raelene Frances in Scott, 'Dear Editor', 79; Jennifer L Graves and Samantha Kwan, 'Is There Really "More to Love"?: Gender, Body, and Relationship Scripts in Romance-Based Reality Television', Fat Studies, 1, no. 1 (2012): 48, doi.org/10.1080/21604851.2012.627791. 
and their experiences as women. We see a tension between narratives of respectable womanhood and how these narratives were contended with by their consumers. We see how their community was constructed and how they negotiated a space that accounted for the inevitably diverse views and opinions of this supposedly homogenised group. ${ }^{89}$

\section{Conclusion}

When I began my research on the Virgilians, I had no sense that this was an archive of fat politics. My eyes scanned over references to 'O.S. types', subconsciously filed away as unimportant miscellany, a term from the era that I did not know-not desirable, but not wholly unusual. It was by chance that I deciphered the code and this world was opened up to me. This raises questions of how studies of private fat worlds would change fat histories. Fat historians must find ways to push beyond traditional languages of fat empowerment and oppression and ask: how did fat people talk to each other? How did they talk to themselves? How did local and global conditions alter their experience? Perhaps, most importantly, we must acknowledge that few, if any, bodies walk throughout the world in a state of constant resistance, and that the negotiation of social and cultural conditions is central to the historicisation of fat. This article has explored the ways in which the letters of rural women to the Western Mails women's pages undermine assumptions about conforming femininity, resistance, and activism. It has suggested that 'O.S.'-identified women made for themselves a community where they could express and share their bodily experiences. Though coded conservative, this became a space where women shared solidarity and supported one another. It was a unique space in their lives where they could air and undermine the fictions spread about their own bodies. Nevertheless, it was also a space where women could reinforce oppressive gender scripts and perpetuate assumptions about what kinds of space 'O.S.' women could take up. This study sits within the still developing field of fat histories, demonstrating that the experience of fat bodies is an essential reflection of contemporary cultural conditions. Finally, it suggests that traditional metrics for considering resistance and conformity do not reflect the varied conditions women have negotiated to share their stories and to create communities.

89 Scott, 'Dear Editor', 80, 82. 


\title{
Female Invisibility in the Male's World of Plantation-Era Tropical North Queensland
}

\author{
Bianka Vidonja Balanzategui \\ James Cook University
}

\begin{abstract}
Australian rural history accounts abound with the admirable, foolhardy and often savage exploits of white male protagonists, while women, white or of colour, are generally invisible. This is despite the fact there is a substantial primary record of the history of European settlement in rural Australia. Taking the Herbert River Valley, located in tropical north Queensland, as a case study, this article fleshes out the scant detail of the women who, alongside the men, battled life on the frontier of European incursion into Indigenous Country. It will focus on the experiences of three women: Manbarra woman Jenny, Melanesian indentured labourer Annie Etinside, and Australian-born Chinese woman Eliza Jane Ah Bow, and how their lives were enmeshed with those of white women who lived alongside them in the Herbert River Valley in the late nineteenth century. These women were hardly bystanders and observers but active participants in the drama of colonisation that melded cultures from across the globe.
\end{abstract}

Women lived in the Herbert River Valley, in the north Kennedy district of tropical north Queensland, from the beginning of European incursion in the area in the late nineteenth century. ${ }^{1}$ Among them was Manbarra woman Jenny, Australian-born Chinese woman Eliza Jane Ah Bow and Melanesian indentured labourer Annie Etinside, as well as white women Isabella Mackenzie, Isabella Campbell, Elizabeth Burrows and Louisa Buchanan. Such women have often been invisible in the historical record as European men, who penned the majority of this history, did not see women beyond their domestic arrangements. The admirable, foolhardy

1 Herbert River Valley hereafter referred to as the Herbert. 
and often savage exploits of white male protagonists abound in Australian rural history accounts. Due to the predominance of men in frontier society, the 'frontier' is assumed to have been a masculine space. However, the significance of women's presence, and what they did, needs to be addressed. The recorded history of the Herbert contains tantalising hints but few details of the women who battled life on the frontier alongside men. This article fleshes out the scant sources on the lives of both white women and women of colour in the Herbert to reveal the diverse ethnic makeup of its female population, thereby providing a new gendered approach to the topic. It will be argued that the women were not passive bystanders and observers but protagonists in the events that played out on the Herbert upon European settlement.

Fleshing out the lives of white women - let alone women of colour-from the few women's memoirs and men's records that remain is no easy task, the more so because they were rural women. Helen Gregory argues that for a long time, rural women were overlooked in feminist historiography. Though Gregory successfully locates rural women and their contributions, she includes only one woman of colour in her study-Dalleburra woman Wyma of central north Queensland. ${ }^{2}$ Majorie Gilmore, writing of the pioneering Atkinson family, and myself, writing of the history of the Herbert, pay ample tribute to European women, their talents, hospitality, energy and bravery. Those European women may be identified and named but Bandyin, Njawaygi, Warrgamay, Melanesian and Chinese women remain faceless. ${ }^{3}$ It is inarguably more challenging to elaborate on the lives of women of colour than those of white women. Kay Saunders argues that in settler accounts of interactions with Indigenous people generally all 'Blacks' were seen as male, making black women invisible. ${ }^{4}$ The same could be said of the Melanesian and Chinese people on the Herbert.

Today, on the Herbert, both academic and family historians are endeavouring to tell the stories of people of colour. In 2017 Gugu Badhun elder and academic Yvonne Cadet-James, together with Robert Andrew James, Sue McGinty and Russell McGregor, published a work that bridged historical scholarship and Indigenous oral tradition to tell the other side

2 Helen Gregory, “The Hearts That Made the Nation”: Fleshing out the Stereotype', Royal Historical Society of Queensland Journal, 20, no. 5 (February 2008): 160.

3 Bianka Vidonja Balanzategui, The Herbert River Story (Ingham: Hinchinbrook Shire Council, 2011).

4 Kay Saunders, 'All the Women Were White? Some Thoughts on Analysing Race, Class and Gender in Australian History', Hecate, 17, no. 1, (31 May 1991): 157. 
of the story of white settlement of the Valley of Lagoons. ${ }^{5}$ Through family and scholarly research, Albert and Rachel Garlando have told the story of a Melanesian woman in the plantation period. ${ }^{6}$ Historian Sandi Robb, working with the Ingham Family History Association, identified both Chinese men and women who lived and worked on the Herbert during the plantation era. ${ }^{7}$ These accounts affirm the significant roles played by women in the late nineteenth century on the Herbert.

This article will argue that despite their invisibility in nineteenth-century records, women, both white and of colour, were vital to sustaining and advancing human endeavour on the Herbert during the plantation era. That they were protagonists is a novel interpretation of plantation life. The protagonists are usually portrayed in the contemporary records as brave and adventurous white men assisted by faceless men of colour. Nineteenthcentury men, living on the Herbert, may have mentioned particular white women in passing in their accounts, but it has not been til the twenty-first century and in research conducted by women that individual women of colour have been identified. This article is significant because for the first time a group of women - white and of colour, living alongside each other in plantation-era tropical north Queensland-have been identified, their lives fleshed out and their contributions acknowledged.

\section{Where are the Women? Male and Female Record Keeping on the Herbert}

The Herbert was opened to pastoralism and plantation agriculture after the explorer George Elphinstone Dalrymple reported favourably on its economic potential in 1864. The vanguard of European settlers arrived in 1868 and began clearing the traditional lands of the Bandyin, Njawaygi and Warrgamay peoples. ${ }^{8}$ The Herbert settlement, with its administrative centre at Cardwell, was then at the extreme limit of European settlement on the north-eastern coast of Australia. Sugar planters were followed by

5 Yvonne Cadet-James, Robert Andrew James, Sue McGinty and Russell McGregor, Gugu Badhun: People of the Valley of Lagoons (Canberra: AIATSIS Research Publications, 2017).

6 Rachel Garlando, 'Annie Gosling and a Family Living Outside the South Sea Islander Experience', Assessment paper, 2 November 2018, James Cook University, Townsville.

7 Re-Discovering 'BUK TI' presented by the Ingham Family History Association Inc.

8 Bianka Vidonja Balanzategui, 'Small Sugar Farmer Agency in the Tropics 1872-1914 and the Anomalous Herbert River Farmers' Association', (PhD thesis, James Cook University, 2019), 168-71. 
small selectors who were not daunted by the remoteness of the Herbert. Among the first of the white interlopers on the lands of the Gugu Badhun was the Valley of Lagoons partnership of Dalrymple and Arthur and Walter Scott, west of Cardwell. They moved sheep and cattle onto the property and appointed Henry Worsley Stone to manage the Vale of Herbert waystation, located in Warrgamay Country (halfway between Cardwell and Valley of Lagoons). Stone set up the waystation in 1864 becoming the first European settler on the Herbert. Neither he nor the Scotts were accompanied by spouses or female relatives.

Despite a substantial extant primary record of the nineteenth-century European presence in the Herbert, and the role of white men in establishing that settlement, it is hard to locate women as active protagonists. ${ }^{9}$ In her study of Sydney business women during the same period, Catherine Bishop comments that 'male diarists did not seem to see women' ${ }^{10}$ Likewise, north Queensland literary scholars Cheryl Taylor and Elizabeth Perkins attribute women's invisibility in men's records to an instinctive adherence to 'the code of contemporary British men in rarely mentioning women or children or domestic arrangements'. ${ }^{11}$ As for businesswomen, Bishop suggests that men did not mention them in their writings because they did not regard the small businesses that women ran as significant in the same way they regarded larger businesses run by men. ${ }^{12}$ In writings of men from the Herbert, white women were referenced with pity, while women of colour, if mentioned at all, were often described with amusement or contempt; sometimes their difficulties—including domestic violence-were significantly trivialised or downplayed. ${ }^{13}$ For example, Walter Scott, commenting on Stone's

9 Robert Arthur Johnstone, Spinifex \& Wattle: Reminiscences of Pioneering in North Queensland Being the Experiences of Robert Arthur Johnstone (East Melbourne: JW Johnstone-Need, 1984); J A B Diary, 'Robert Mitchell Boyd (1849-1912)', connorhistorycom.files.wordpress.com/2017/12/boyd-robertmitchell-boyd-1849-1912-references.pdf; Arthur Neame, The Diary of Arthur Neame, 1870-1897, ed. Sydney May (Aitkenvale: Terry Lyons, 2003); Jas Cassady for FA Cassady, JC/1 Original notebook James Cassady Archive, Special Collections, James Cook University, Townsville; John Alm, Early History of the Herbert River District being 'The Memoirs of the Early Settlement of the Lower Herbert and the Start and Progress of the Sugar Industry in the District, 1932/33/35' (Aitkenvale: Terry Lyons, 2002); Alec S Kemp, The Kemp Report, unpublished text, n.d.; T Weitemeyer, Missing Friends: Being the Adventures of a Danish Emigrant in Queensland (1871-1880) (London: T Fisher Unwin, 1892).

10 Catherine Bishop, Minding Her Own Business: Colonial Businesswomen in Sydney (Sydney: UNSW Press, 2015), 11.

11 Cheryl Taylor and Elizabeth Perkins, 'Warm Words; North Queensland Writing', in By the Book: A Literary History of Queensland, eds. Patrick Buckridge and Belinda McKay (Brisbane: University of Queensland Press, 2007), 219, doi.org/10.20314/als.d3884732cb.

12 Bishop, Minding Her Own Business, 11-12.

13 See, for example, Walter Scott to station manager, Frederic Beazley, Correspondence, 17 December 1886, Valley of Lagoons Station Deposit, Noel Butlin Archives Centre [hereafter NBAC], M27. 
apparent heavy drinking and his treatment of his housekeeper Maria, the wife of stockman Duncan McAuslan, wrote in a letter: 'I am sorry to hear Mrs McAuslan has had a bad time'. Norwegian anthropologist Carl Lumholtz met Nelly, the Aboriginal wife of a Melanesian labourer in 1882. The Melanesian labourer was the nominal housekeeper for the caretaker of the Vale of Herbert property, but Lumholtz noted that the burden of the work fell on Nelly. Lumholtz's descriptions of Nelly are largely tongue-incheek, and lacking any real empathy with the brutality of her existence. In his opinion 'her existence was a happy one, marred only by an occasional flogging from her husband'. ${ }^{14}$

However, not all men were so dispassionate. Pastoralist James Cassady recounted with rage how he took in another Indigenous woman named Nelly, who was viciously wounded by a trooper of the Native Mounted Police (a paramilitary force used as a means of control, and generally consisting of a group of Aboriginal trackers under the command of European officers). ${ }^{15} \mathrm{He}$ attended to her, giving her food and tending to her health for 10 weeks. ${ }^{16}$ In letters to close relatives, men could be less guarded, and thus these sources often contained more personal details about the lives of the women they lived with. Pastoralist Henry Atkinson of Wairuna (adjacent to Valley of Lagoons) wrote to his brother to tell him that he and his wife had just farewelled a stillborn baby. He wrote:

Little baby died on Monday night perhaps it was as well coming as it did before its time but it is hard to lose them. Isabel is doing well. She is quite cheerful—unless her breasts give trouble which I don't anticipate she will soon be quite well. I want you to come over, you will cheer the girls up a bit $\&$ I want a chat on business. I can't leave as I have to act baby and draw Isabel's milk. ${ }^{17}$

14 Carl Lumholtz, Among Cannibals: Account of Four Years Travels in Australia, and of Camp Life with the Aborigines of Queensland (Canberra: Australian National University Press, 1980), facsimile of 1888 edition, 89.

15 Jonathan Richards, The Secret War: A True History of Queensland's Native Police (Brisbane: University of Queensland Press, 2008).

16 'The Way We Civilise', Brisbane Courier, 27 October 1880, Trove, National Library of Australia; James Cassady to Colonial Secretary, 1 May 1880, Queensland State Archives [hereafter QSA], $847023,80 / 2307$.

17 Henry Atkinson to Tom Atkinson, Wairuna Letterbook, letter number 554, 2 November, 1898, quoted in Majorie Gilmore, On Eagles Wings: The Atkinsons of North Queensland 1862-2014 (Peregian Beach: Queensland, Tableland Research and Consultancy Services, 2015), 123. 
On the whole, however, men predominantly recorded their own and other men's exploits, or the daily running of their properties. Women's invisibility in those records insinuates a lack of agency; in reality, women in the Herbert were integral to the everyday running of properties, and had multifarious skills men depended on.

Women's records are very different in tone to men's recounts and offer intimate glimpses into their everyday lives on the Herbert. Their writings convey both the emotional and material hardship of family life on the colonial frontier. The diaries of Violet Wickham, who lived in the Herbert for nine years with her planter husband, and Augusta (Gussie) Feldt, a Swedish immigrant and the wife of a small farmer, reveal that women could nevertheless retain an indefatigable sense of humour. Violet, commenting on the double tragedy of losing her house in a fire and then damage to the next in a cyclone, wrote: 'Having been burnt out it seemed necessary for me to try the water cure'. ${ }^{18}$ Gussie had a droll turn of phrase. In the teeth of a cyclone she and her husband lay fearfully on the bed with the big lamp under the little dressing-table and the Ansonia clock on top of the table. Every time a big jerk shook the house, out went the lamp and the clock was like a man who was hesitant to write out a cheque. ${ }^{19}$

Women also left a variety of other written sources. Planter's wife Eliza Agnes Boyd kept a recipe book that included medical treatments for family and labourers. Those treatments are a clear example of the assistance women could provide in the absence of professional medical help. The book also contains, most poignantly, a pattern for baby's booties; Eliza would not only bury a child on the Herbert but die there in childbirth. ${ }^{20}$ Even when such records exist, they cannot always be accessed. Letters written by Stone's wife Anna are very frank. Because the custodians feel the comments about individuals may offend their descendants, the letters are under restricted access. ${ }^{21}$ Les Pearson, who was able to circumvent this restriction, writes that the letters reveal that Eliza was a skilled tailoress who made all her own clothes, as well as those for her extended family and husband. Sadly, she never birthed a live baby, and referred to her

18 Violet Wickham, A Lady's Experience in Many Lands as quoted in Edward V Lane, 'Life and work of Henry Wickham', V-'Pioneering in north Queensland', The India-Rubber Journal, 2 January 1954, 18. Another example includes Kate Atkinson Diary, Virginia Bowman collection, Mudgee, NSW.

19 Augusta (Gussie) Feldt, Gussie’s story, unpublished typescript, 17.

20 Receipt Book, E A B, connorhistorycom.files.wordpress.com/2020/02/eliza-agnes-boyd-receiptbook-transcript.pdf.

21 Les Pearson, Henry Stone: A Pioneer with Dalrymple (Brinsmead: L M Pearson, 2007), 24. 
still-born babies as her 'little mites'. ${ }^{22}$ Occasionally women writers visited the Herbert and observed women in a way that men seldom did. Marion Ellis Rowan, the renowned author and traveller, attending an 'amusing' agricultural show in the town of Ingham observed 'mothers ... nursing their babies in most delightful unconcern'. ${ }^{23}$ The surviving memoirs, letters, recipe books and reportage of women who either lived on, or visited, the Herbert provide intimate details of daily life and confirm the range of tasks women undertook. They provide a first-hand account of the physical dangers and emotional toll of living and working in tropical Queensland during the plantation era.

\section{White Women on the Herbert}

While past writers have presented the economic development of the Herbert as a triumphal, white male endeavour, women were there from when the very first stick of cane was planted. If any women are identified in men's records by name and deed it is white women. The first mention of a white woman on the lower Herbert was Italian housekeeper Caterina Cordelia, who worked for licensed surveyor, Maurice Geoffrey O'Connell, his brother John Geoffrey and William McDowall (McDowell). ${ }^{24}$ Caterina was the first of many Italians to make the Herbert their home. First welcomed in the plantation era, as restrictions on the use of Melanesian indentured labour tightened, they were regarded as swarthy enough to be a suitable replacement labour while simultaneously conforming to prevailing ideals of whiteness. Italians, therefore, occupied a dichotomous space in Australia in the attribution of whiteness, especially with the enactment of the White Australia Policy in $1901 .^{25}$ Caterina and her

\section{Ibid.}

23 Marion Ellis Rowan, A Flower-Hunter in Queensland and New Zealand (London: John Murray 1898), 25-6.

24 Kemp, The Kemp Report, 5. Geographically, the lower Herbert area extends from the Seaforth Delta to the junction of the Herbert and the Stone Rivers. Later, lower Herbert came to mean the reach of the river between the town of Ingham, and the Herbert's mouth at Seaforth.

25 Lara Palombo, 'Whose Turn Is It? White Diasporic and Transnational Practices and the Necropolitics of the Plantation and Internment Camps', Australian Critical Race and Whiteness Studies Association, 3 (2007): 1-20; Catherine Dewhirst, 'Collaborating on Whiteness: Representing Italians in Early White Australia', Journal of Australian Studies, 32, no. 1 (2008): 33-49, doi. org/10.1080/14443050801993800; Jane Carey, Leigh Boucher and Katherine Ellinghaus, 'Historicising Whiteness: Towards a New Research Agenda', in Historicising Whiteness: Transnational Perspectives on the Construction of an Identity, eds. Leigh Boucher, Jane Carey and Katherine Ellinghaus (Melbourne: RMIT Publishing in association with the School of Historical Studies, University of Melbourne, 2007). 
companions arrived on the lower Herbert in 1868 when Indigenous people were still cautiously watching their activities from a distance. ${ }^{26}$ The men came to plant sugar but had no designs for a mill or any idea who would crush their cane. There were no public facilities as the European population numbered little more than 12 people. ${ }^{27}$ How Maurice inveigled Caterina to accompany him will forever remain a mystery, but there is no doubting her fearlessness and sense of adventure. 'Housekeeper' could be a euphemism for a more intimate relationship and some infatuation on the part of O'Connell is indicated by several landscape features, namely a creek and a hill, being named after his housekeeper. What happened to the O'Connells and McDowall after their brief stay on the Herbert can be tracked through newspaper reports and documents, but Caterina Cordelia remains an enigma. She epitomises the invisible white woman in plantation-era tropical north Queensland.

The next white woman on the Herbert that can be profiled from the male record is 28-year-old Isabella Mackenzie. She arrived in Cardwell in 1870 and was accompanied by her large extended family. She and two of her brothers moved to the lower Herbert in $1871 .{ }^{28}$ In that year, the European population of the upper and lower Herbert numbered 140 males and 29 females, the Melanesian numbered 63, and the Indigenous population less than $500 .{ }^{29}$ Unlike the O'Connell party, the Mackenzies had the knowledge and access to capital required to establish the first sugar plantation and mill on the Herbert (Gairloch) and used both Indigenous workers and indentured Melanesian labourers to clear the land and establish their mill. Isabella Mackenzie did not lack in means or courage. She owned plantation land, lived in a rough cottage and, soon after her arrival on the Herbert, raced others overland on horseback to Cardwell to the Land Agent's Office there-a difficult rough journey over the Seaview Range-to secure title to a selection for a friend. ${ }^{30}$ Nevertheless, when drinker and hot-head William Stewart obtained the

26 'Bowen', Queenslander, 16 January 1869, 5 (Trove); 'The Flaneur in Sydney', Empire (Trove), 16 January 1869,5 .

27 'Cardwell and the Vale of Herbert', Queenslander (Trove), 23 September 1871, 10.

28 Kemp, The Kemp Report, 5.

29 Douglas R Barrie, Minding My Business: The History of Bemerside and the Lower Herbert River District of North Queensland Australia (Ingham: Douglas R. Barrie, 2003), 28; Kay Saunders, Workers in Bondage: The Origins and Bases of Unfree Labour in Queensland 1824-1916 (Brisbane: University of Queensland Press, 1982), Table 4, 48; Helen Brayshaw, Well Beaten Paths: Aborigines of the Herbert Burdekin District, North Queensland. An Ethnographic and Archaeological Study (Townsville: James Cook University, 1990), 32.

30 Barrie, Minding My Business, 25. 
manager's position at Gairloch, he and Isabella quickly married. ${ }^{31}$ As the ratio of males to females was eight to one, Isabella would not have lacked for choice. ${ }^{32}$ Why she rushed into marriage with a ne'er-do-well puzzled even her contemporaries. Planter Arthur Neame, owner of Macknade, wrote in his diary that Isabella's marriage to William was 'much to the astonishment of everyone. It did not result in a happy life for her'. ${ }^{33}$ Isabella's daughter Elizabeth Charlotte was born on 7 June 1875 and in the same year Gairloch plantation was repossessed by the bank. ${ }^{34}$ Isabella and her husband William vainly tried to continue farming but then left the district. ${ }^{35}$

Isabella Mackenzie was accompanied by a female companion, 32-yearold widow Isabella Campbell, and her three children. A little more is known about her because her daughter wrote a short reflection on life on the Herbert in the late nineteenth century. ${ }^{36}$ Isabella Campbell also married soon after arrival on the Herbert. Like other single women and widows, she had made the hazardous journey to frontier areas to start a new life. In times when women depended on men for social security, widows, especially those with children to support, were impelled to find a new husband as soon as possible and nowhere was that more likely than on the frontier where women were few. Being accompanied by children was no impediment. Historian Katie Spearritt notes that in the years 1859 to 1889 Queensland had the highest marriage rate of the colonies. In the Kennedy district, between 80 and 90 per cent of women were married. ${ }^{37}$ It is perhaps understandable then that Isabella Campbell married immediately after she alighted from the ship in Cardwell given that she was a widow with young children to support.

\footnotetext{
31 Neame, Diary of Arthur Neame, 34.

32 Katie Spearritt, 'The Sexual Economics of Colonial Marriage', in On the Edge: Women's Experiences of Queensland, ed. Gail Reekie (Brisbane: University of Queensland Press, 1994), 66-7.

33 Neame, Diary of Arthur Neame, 34.

34 Queensland Registry of Births, Deaths, Marriages and Divorces (QRBDMD), registration details: $1875 / \mathrm{C} / 9$.

35 'Lower Herbert', Brisbane Courier (Trove), 23 October 1875, 7; 'The Exhibition', Brisbane Courier (Trove), 24 August 1876, 3; Peter Griggs, "Rust” Disease Outbreaks and Their Impact on the Queensland Sugar Industry, 1870-1880', Agricultural History, 69 (1995): 413-37.

36 'Early History: As told by an old pioneer', published in instalments in the Herbert River Express, 1947.

37 Spearritt, 'The Sexual Economics of Colonial Marriage', 66-7.
} 
White women and coloured alike experienced economic and sexual exploitation. Employment opportunities for white women in the Herbert were few, apart from those of domestic, housekeeper or companion, while marriage offered economic and sexual protection in a male-dominated society. However, there was little real protection as being a wife exposed women to exploitative obligations and transactions, particularly sexual, which were codified by colonial law. ${ }^{38}$ Aboriginal women made up the largest portion of female inhabitants on the Herbert. They were absorbed into the workforce not only as domestics but as field workers and, as female Melanesian indentured labourers were few, Melanesian men partnered with Aboriginal women. Single white men like Walter Scott and Stone were dependent on women's labour, in particular the white housekeepers and Indigenous women that they pressed into domestic roles.

Hotel keeping was one domain where women could secure independence and authority. Isabella Campbell and her new husband George Wickham went on to establish a hotel, the Planter's Retreat, in 1875 in an auspicious location, at the landing where passengers alighted for the road journey to the upper Herbert. Isabella employed Indigenous people and catered for the weddings of the local Chinese population. She benefited from the fact that in Australia hotel keeping by women was encouraged and legislated for and privileged women's 'rights as commercial traders over their sexual identities as women'. ${ }^{39}$ The woman hotelier, with her 'feminine qualities of dignity, hospitality, and maternal self-restraint', was regarded as an antidote to the disorderly drunkenness common in male-dominated frontier communities. ${ }^{40}$ Their autonomy in that space was rarely challenged, particularly as they had the backing of the Licensed Victuallers Association and the breweries. Isabella Campbell managed the Planter's Retreat in her own right from 1882 to 1892 . She would live out her life on the Herbert, dying there in 1902.

Another woman Isabella Mackenzie and Isabella Campbell were acquainted with was Elizabeth Burrows. Few personal facts are known but the sensational nature of her death meant that male writers recorded

38 Ibid., 67.

39 Clare Wright, Beyond the Ladies Lounge: Australia's Female Publicans (Melbourne: Melbourne University Press, 2003), 5, 17.

40 Claire Wright, 'Women Publicans (Australia)', in Alcohol and Temperance in Modern History. An International Encyclopedia, Vol. 1: A-L, eds. Jack S Blocker Jnr, David M Fahey and Ian R Tyrrell (Santa Barbara: ABC-CLIO, 2003), 682-3. 
it in detail. ${ }^{41}$ Elizabeth kept to herself and together with her husband, William George Conn, a small selector, lived on a picturesque but isolated selection they named the Hermitage. Elizabeth was 20 years younger than her husband. In this period in Queensland 48 per cent of women lived in rural areas, compared to 64.5 per cent of men, hence the high marriage rates in the Kennedy district. Given that sexual imbalance, marriage or common-law partnerships offered protection against sexual predation, for a woman to be younger than her husband was not unusual. The average marriage for a female in 1875 was 23 years. ${ }^{42}$ We will never know whether Elizabeth was with William for love or opportunity but she proved herself capable to take on the hard, physical work typical of small settlers and their families. Arthur Neame observed the Conns building a hut with William on the ground and Elizabeth on the roof putting on the thatch. ${ }^{43}$ Prior to 1875 there had been few violent confrontations between settlers and the Indigenous people on the lower Herbert; nevertheless, other settlers feared for the Conns' safety. The Conns trusted the Indigenous people and according to contemporary accounts treated them kindly. ${ }^{44}$ When they were brutally murdered by a group of Aborigines on the morning of 7 April 1875, retribution was immediate and merciless. The tragic consequence was that the actual perpetrators may have got away while many Aborigines who had nothing to do with the massacre, including women and children, were slaughtered. ${ }^{45}$

Louisa Buchanan was a contemporary of these women though none had the opportunity to call upon her services as midwife. Details of her life and work as a midwife are meagre. Arriving on the Herbert as a child, Louisa married Swedish immigrant Christian Anderssen (Anderson) in 1879. When Christian was invalided after sustaining a severe injury while shoeing a horse, Louisa turned to midwifery to support the family. She was self-taught. ${ }^{46}$ Midwifery, like hotel keeping, was a respectable profession for a woman and one to which women turned because of a need to earn

41 Johnstone, Spinifex \& Wattle, 58-60; Neame, Diary of Arthur Neame, 48; 'The Murder of Mr \& Mrs Conn on the Herbert River', Toowoomba Chronicle and Queensland Advertiser (Trove), 1 May 1875,3 .

42 Katie Spearritt, 'The Market for Marriage in Colonial Queensland', Hecate, 16, no 1/2

(30 November 1990): 23.

43 Neame, Diary of Arthur Neame, 48.

44 Ibid.; Barrie, Minding My Business, 67; Brisbane Courier (Trove), 14 May 1875, 3.

45 James Cassady, diary entry 20 May 1875, in Jas Cassady for FAO Cassady, JC/1 original notebook; 'Letters to the Editor', Queenslander (Trove), 4 September 1880, 306; 'Black v. White', Brisbane Courier (Trove), 7 October 1880, 5.

46 Finlay Skinner, Memories of a First World War Digger (Nambour: Finlay Skinner, 1981), 17. 
a living after being widowed or a husband being incapacitated. ${ }^{47}$ At that time, infant mortality rates in Queensland were one in eight before the age of one, and with a lack of qualified medical assistance to deal with birthing complications women, understandably, faced pregnancy and childbirth with considerable trepidation. ${ }^{48}$ Childbirth was considered women's business and women relied on each other, and white women even relied on their Indigenous and Melanesian domestics. Whether Louisa assisted women of colour, either in their confinements or postpartum, is not known. Despite enormous loss and hardship-the deaths of three children, an invalid husband, and children to raise-Louisa responded to calls for assistance at any hour of the day or night and was even known to have swum a river to attend to a woman in labour. ${ }^{49}$ Louisa lived to 84 , dying in 1948 in a nursing home in Charters Towers. She was predeceased by all but one of her seven children.

The contributions of these white women-Isabella Mackenzie, Isabella Campbell, Elizabeth Burrows and Louisa Buchanan-to the opening of the Herbert to European settlement and economic development are only mentioned in passing in the male record, making them virtually invisible to later researchers. This occurred whether they left the district, met an early death, or lived out their lives on the Herbert, and in spite of the fact that men and women alike depended on their multifarious skills. Housekeeper, planter, hotel keeper, midwife and small farmer; here, for the first time, these women have been identified, their lives fleshed out and their domestic and gendered contributions to the advancement of European settlement on the Herbert acknowledged as important.

\section{Women of Colour on the Herbert}

\section{Jenny}

Living alongside the white women whose lives have been recounted here were women of colour: Indigenous Aboriginal, Melanesian and Chinese. Though they occupied very different spaces socially, they could hardly have been unaware of each other. Manbarra (Palm Island) woman Jenny

47 Trisha Fielding, Neither Mischievous nor Meddlesome: The Remarkable Lives of North Queensland's Independent Midwives 1890-1940 (Townsville: North Queensland History Press, 2019), 3.

48 Spearritt, 'The Sexual Economics of Colonial Marriage', 69-70.

49 Skinner, Memories of a First World War Digger, 17. 
(Janny) lived on the pastoral property of James Cassady, which had been Njawaygi land; Annie Etinside in the home of a small selector; Eliza Jane Ah Bow in Chinatown in the vicinity of Isabella Campbell's Hotel. Alongside the white women, they were vital to sustaining and advancing human endeavour on the Herbert during the plantation era, often at great physical and emotional hardship.

Jenny would have been in her teens when those white women whose stories have been recounted above came to live on the Herbert. In their time, the Indigenous people's attitudes to the European incursion on their country went from cautious curiosity to fierce resistance to resigned acceptance. ${ }^{50}$ We can gain some idea of the traditional life of Indigenous women on the Herbert from the contemporary writings of naturalist Lumholtz and Robert Arthur Johnstone, Sub-Inspector of the Native Mounted Police. Contemporary newspaper depictions, both in Australia and overseas, of the Indigenous men and women on the Herbert tend to focus on the threat they represented and their 'barbarity', an image Lumholtz perpetrated rather than dispelled. ${ }^{51}$ Displaced and cut off from their traditional food sources, water supplies, trade routes and ceremonial grounds, they were subdued and 'let-in'. ${ }^{52}$ Retributive action taken by Europeans in response to Indigenous efforts to survive and resist the Europeans had reduced the Herbert Indigenous male population drastically, leaving an imbalance of men to women. ${ }^{53}$ By Jenny's time, women were clinging to traditional life while attempting to accommodate white cultural and economic practices and the expectations of white employers. Kate Atkinson, who relied on Indigenous women for heavy household tasks, complained that they were unreliable and prone to take off without warning. ${ }^{54}$ Her incomprehension was typical.

This was the situation when Jenny encountered Barnum and Bailey Circus agent Robert A Cunningham. People displaced and dispersed by colonisation were recruited to perform in Barnum and Bailey's travelling

50 An account of this progression is detailed in Cadet-James et al., Gugu Badhun: People of the Valley of Lagoons.

51 'Cannibals of Australia', San Francisco Call, 72, no. 115, 23 September 1892, 1.

52 'Keeping-out' entailed the forcible removal of Aboriginal people from land used by Europeans for pastoral or agricultural purposes; 'letting-in' happened when Aboriginal people ceased resisting and moved onto Europeans holdings and to the outskirts of towns where they became an important source of cheap labour.

53 Roslyn Poignant, Professional Savages: Captive Lives and Western Spectacle (Sydney: UNSW Press, 2004), 55.

54 Gilmore, On Eagles Wings, 85. 
circus, dime museums, fairgrounds and exhibitions in Europe and America. They performed alongside so-called human freaks and oddities. These displays fascinated European audiences. Among the performers, and of particular ghoulish fascination, were Indigenous Australians, who were portrayed as cannibals. ${ }^{55}$ The Indigenous Australians' displays of culture reinforced for white audiences their own technical advancement, while anthropologists took the opportunity to examine, measure and photograph the performers. Their findings generally supported contemporary ethnographic theories of white superiority compared to Aboriginal 'savagery'. ${ }^{56}$

We know of Jenny because of the painstaking research of Roslyn Poignant, who describes two groups of Indigenous Australians recruited from north Queensland. The first group of nine left Australia in 1883 and included two women. The second group of eight left in 1892 and also included two women, Jenny and Tottie (Dottie). ${ }^{57}$ What enticements were used by the recruiters, and to what degree they were coerced, is open to conjecture. However, kidnapping of Indigenous men, women and children by Europeans was common practice. ${ }^{58}$ In Gugu Badhun: People of the Valley of Lagoons, an entire chapter is dedicated to the practice. Cassady commented about it in a letter to the Queenslander where he wrote:

It is not a very uncommon thing for Native police officers to kidnap gins and boys. I know of a good many people in this locality that are indebted to Sub Inspector Armit for the black boy or gin they have got. ${ }^{59}$

On Cassady's arrival on the Herbert in 1873, he began voicing his concerns about the way he saw Indigenous men, women and children being treated by the Europeans, and the actions of the Native Police. He wrote letters to newspapers and to government representatives. An example of the correspondence entered into is to be found in the 'Black v. White' debate in letters to the editors of several Queensland newspapers.

55 'The Circus Napoleon: An Interesting Reminiscence of the late PT Barnum', Los Angeles Herald (CDNC), 36, no. 18, 5 May 1891, 5.

56 See Henry Reynolds, Frontier (Sydney: Allen and Unwin, 1987), 108-30.

57 Poignant, Professional Savages, 21, 204.

58 Raymond Evans, Kay Saunders and Kathryn Cronin, Race Relations in Colonial Queensland: A History of Exclusion, Exploitation and Extermination (Brisbane: University of Queensland Press, 1993), 102-17.

59 'Letters to the Editor: The Way we Civilize', James Cassady, Queenslander (Trove), 23 October 1880,530 . 
Cassady employed Indigenous and Melanesian men and women on his Fairview and Mungalla properties. On Mungalla they worked in the house, garden and stables, and lived in established communities on the property. ${ }^{60}$ These people saw him as a protector while the wider community vilified him, particularly the officers of the Native Mounted Police. Cassady stated: 'I was accused I constituted myself black protector for my own interests, and to the detriment of my neighbors' property. ${ }^{61} \mathrm{~A}$ neighbouring property was Molonga owned by Sub-Inspector Johnstone. Cassady was most critical of the Native Police and the superior officers, including Johnstone. For a man who offered safe haven on his properties to the Indigenous owners and Melanesians, it is understandable then that he was angry and demanded answers when in his absence some of the people from his Mungalla property were inveigled by Cunningham in 1892 to go with him to appear, ostensibly, in the World's Columbian Fair in Chicago in $1893 .{ }^{62}$

Jenny's group were recruited either from Mungalla or from Townsville where they may have gathered for ceremonial business. Jenny was accompanied by her husband Dilagroo or King Bill (also William or Bell). That he was a Njawaygi man can be identified by his body marks or scarifications. ${ }^{63}$ Njawaygi shared a close kinship system with the Manbarra of Palm Island and intermarriage was permitted. ${ }^{64}$ Jenny is likely to have been a domestic servant, and King Bill stated that he had worked with cattle for the European settlers. ${ }^{65}$ However, while only one of the group may have been a black tracker with the Native Mounted Police, they were all portrayed as such in the American press. ${ }^{66}$ That they originated from the Herbert is confirmed by reports that described the group as 'the Ingham blacks' and their scarifications as the 'favourite style of decoration $\ldots$ of the Ingham tribe'. ${ }^{67}$ The other woman in the group, Tottie, was the wife of a group member also called William and biological brother of King Bill. In addition to being Njawaygi, there is also suggestion that some members of the group could have been part Melanesian. ${ }^{68}$

60 Deidre Pope, New Beginnings: The Roche Family (Deidre Pope, 2017), 100-25.

61 'Letters to the Editor, 'Black v. White', Queenslander (Trove), 2 October 1880, 433.

62 Under Colonial Secretary to the Hon A S Cowley, 11 August 1896, QSA, 861465, 96/4761.

63 Poignant, Professional Savages, 205-6.

64 Ibid., 207.

65 'Held in Slavery on Coney Island', New York Journal (LOC), 19 July 1896, 36.

66 'The Boomerang Throwers', San Francisco Call (CDNC), 72, no. 115, 23 September 1892, 7.

67 'They Possess Sand', Los Angeles Herald (CDNC), 39, no. 103, 22 January 1893, 10.

68 Display panel, second group, Exhibit: Professional Savages. Captive Lives and Western Spectacle. Mungalla Station, Ingham. 
The Queensland authorities insisted on formalising the taking of eight Indigenous people out of the country. Cunningham was required to pay a security of $£ 500$ for their safe return, be able to account for their nonreturn, and prove that the group understood the terms of their agreement. ${ }^{69}$ Since the bond document is missing, it is unknown how Jenny's name, age and origin were recorded. ${ }^{70}$ Even given her good command of English, the degree of her complicity is to be questioned given the power imbalance prevailing between people of colour and whites. ${ }^{71}$ Jenny may have seen the opportunity to travel as a novel experience, but whether she understood the distances and the time that they were expected to be out of the country is another matter. Paperwork signed, the group were hurried on board the Peregrine. At Sydney, they were transhipped to the SS Monowai. Before they had even reached San Francisco in the last week of September, they were already wanting to return home. ${ }^{72}$ Provided with inadequate clothing, 'they huddled together and shivering with cold on the foredeck'. Jenny and Tottie each had only 'a thin shawl and petticoat and their thin limbs quite bare ... their eyes had a sad faraway look'. ${ }^{73}$ On arrival in San Francisco they were immediately put to work displaying their skills of boomerang throwing in Central Park. During the performance, Jenny and Tottie sat alone on the grandstand. They were now wearing 'calico garments and each wore an untrimmed red felt hat with a high dome-like crown'. ${ }^{74}$

Cunningham reported back that the group was happy and thriving, but complained that for his purpose of showcasing 'primitives' they were far too civilised. ${ }^{75}$ Nevertheless, despite their clearly civilised demeanour they were consistently described as 'man-eating. ${ }^{76}$ Portrayed as savages, they did not see themselves as such. As King Bill emphatically stated: "We are not savages although we are natives of a wild country. ${ }^{\text {'77 }}$ Initially they were feted and put up in fine hotels and performed in theatres and large grounds and halls. They were paid and, according to Cunningham,

69 Under Colonial Secretary WE Parry-Okeden to GA Roberts and Leu Solicitors, Townsville, 7 July 1892, QSA, 861429, 92/3922.

70 Poignant, Professional Savages, 211.

71 'Shivering Aborigines', San Francisco Call (CDNC), 2, no. 95, 3 September 1892, 2.

72 Ibid.

73 Ibid.

74 'Australian Aborigines Show How It Is Done', San Francisco Call (CDNC), 72, no. 115, 23 September 1892,5 .

75 'Townsville Blacks in America', Telegraph (Trove), 28 December 1892, 5; Poignant, Professional Savages, 217-18.

76 'The Boomerang Throwers', San Francisco Call (CDNC), 72, no. 115, 23 September 1892, 7.

77 'Held in Slavery on Coney Island', 36. 
were enjoying city life and the services and goods they could procure. ${ }^{78}$ Despite this, members of the group were in fact dying. While the climate of California had suited them, an American winter was another matter. It can only be imagined how Jenny felt when Tottie succumbed at the end of winter, 1893. By 1895 their number was reduced to four, possibly from the effects of exposure to the elements and neglect. While previously they had been applauded and had been able to give somewhat meaningful displays of their skills and culture, as time passed they were reduced to being exhibited in sideshow alleys and were living in cheap boarding houses in the slums. In the winter months they were left to their own devices. ${ }^{79}$ However their managers chose to view their charges' condition, the reality was very different. King Bill insisted that 'thousands of times we have complained about our pay and board, and begged, with tears, of Mr Trask [sic] to send us back, but he gave us no hope'.$^{80}$ King Bill and Jenny were very aware of the extent to which they were being exploited, and declared unequivocally that they knew that Cunningham's lifestyle in America was made at their expense. ${ }^{81}$ Nevertheless, they were compliant, doing what was asked of them. This compliance was extracted, in Poignant's view, with 'economic deprivation and manipulative brutality that undermined their sense of self-worth'. ${ }^{82}$ Already conditioned to this treatment on the Herbert, they were easy prey. King Bill's behaviour and words attested to this. Speaking to a New York Journal reporter in 1896, his eyes darted about in fear and he stated that when they have complained of their conditions of virtual imprisonment they were told to 'shut up' and that they 'couldn't do otherwise'. ${ }^{83}$

After the United States, they travelled on to Germany, the Netherlands, Sweden and Norway, though on leaving the US they may have thought they were going home. In 1896 three of the original group were still alive in Berlin: Jenny, King Bill and William (the husband of Tottie), at which time an anthropological examination was conducted. ${ }^{84}$ Somewhere after this time Jenny's husband King Bill died. According to one account,

\footnotetext{
78 Poignant, Professional Savages, 214-23.

79 Ibid., 219-27.

80 'Held in Slavery on Coney Island', 36.

81 Poignant, Professional Savages, 228, 234; 'The Palm Island Travellers', North Queensland Herald,

19 December 1898, 27.

82 Poignant, Professional Savages, 229.

83 'Held in Slavery on Coney Island', 36.

84 Rudolf Virchow et al., 'Drei Australier' (17 October 1896), Zeitschrift fur Anthropologie, Ethnologie und Urgeschichte, 28, 1896, 461-532.
} 
Jenny and William paid their own fares from Germany to England; an alternative account suggests that Cunningham paid them. From there, their fares back to Queensland were paid by the British government as deck passengers on the Duke of Portland, setting sail on 30 September $1898 .^{85}$ On arrival in Townsville they were met by the police and came under the Aboriginals Protection and Prevention of the Sale of Opium Act 1897, which had been enacted in their absence. ${ }^{86}$ This meant that they could not freely return to Mungalla and may have been immediately placed on a reserve or mission. The name Jenny is ubiquitous (one of the women in the 1883 group was also named Jenny), so tracing Jenny's whereabouts after arrival in Townsville is impossible, especially as correspondence regarding her situation between the Home Secretary and Townsville Police has not survived. ${ }^{87}$

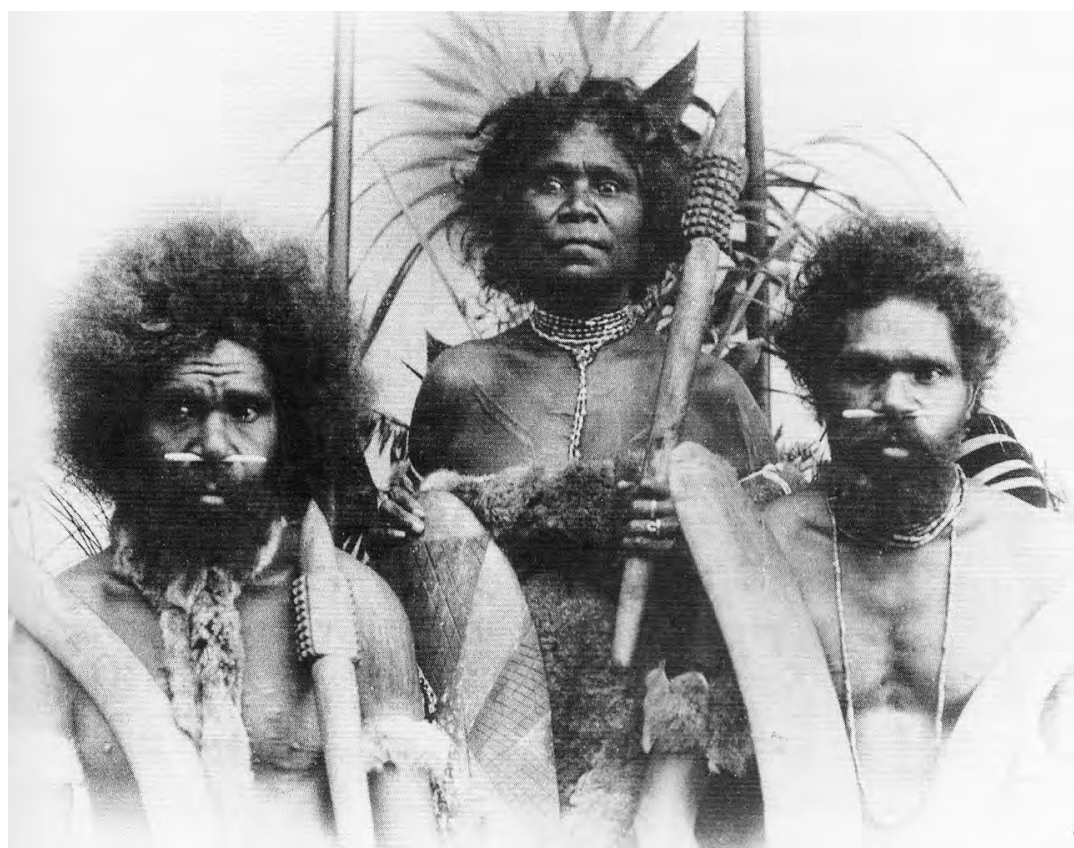

\section{Figure 1: (left to right) William, Jenny and King Bill.}

Source: Wilhelm Scharmann, Berlin, 1896 in Roslyn Poignant, Professional Savages:

Captive Lives and Western Spectacle (Sydney: UNSW Press, 2004), 233.

85 Poignant, Professional Savages, 234-5.

86 Aboriginals Protection and Preventions of the Sale of Opium Act, Qld, 1897.

87 Poignant, Professional Savages, 62, 235, 275. 
Though we know of Jenny's experiences under the supervision of Cunningham and other showmen, as is the case with all these invisible women in this account, we are left to imagine her emotions. We do know from newspaper articles that she found the long journey to America uncomfortable and was already wanting to go home. Once in America she would have felt denigrated as she listened to herself and her husband being described as 'true representatives of the lowest type of humanity'. ${ }^{88}$ Despair would have set in with the discomfort of cold winters, the growing disillusionment as their performances became less meaningful, their accommodation less salubrious and their pay less. Undoubtedly, she felt embarrassed as she was examined and photographed as an anthropological specimen. ${ }^{89}$ Finally, the enormous sorrow as she saw companion after companion, including her husband, succumb to death must have been overwhelming. Unable to return to her own Country, her homecoming was bittersweet. Jenny's story illustrates how one Aboriginal woman living on the Herbert in the plantation era attempted to determine a life for herself through accommodation of white cultural and economic practices, albeit with tragic consequences.

Jenny's story is important because she is an identified Indigenous woman who lived in the plantation era on the Herbert and survived the initial conflict between the Indigenous peoples and European interlopers. At the time of her encounter with Cunningham, she was contributing to the economy of the Herbert in her capacity as house servant; such domestic labour, even by white women, is too often obscured by the masculine biases of the historical record. What is all the more remarkable is that a reconstruction of a brief period of her life has been able to be made, especially given the period in which she lived and that the episode played out on distant shores. The irony is that once she returned to Australia she disappeared from the records. The prevailing racial attitude in the nineteenth and early twentieth centuries was that Aboriginals were 'intellectually at the bottom of the list of existing races comprising the human family'. ${ }^{90}$ Ethnographic and anthropological theories determined not only her recruitment by Cunningham, but the way overseas audiences perceived her. Those theories also underpinned Australian legislation in regards to the Indigenous population and enabled Jenny, and countless

88 'Shivering Aborigines,' 2.

89 Virchow, 'Drei Australier', 528-32.

90 Reynolds, Frontier, 78. 
Indigenous women like her, to be spirited away, out of anybody's memories. Today Jenny represents those invisible lives and by telling her story their manifold contributions are acknowledged.

\section{Annie}

Like Jenny, Annie Etinside Barslo, a Melanesian indentured labourer, was removed from her homeland, deprived of family and alienated from her culture. Despite the colour of her skin, which clearly betrayed her as non-white, the truth of her origins was hidden from her children and grandchildren. Melanesian women started arriving on the Herbert in the early 1880s, more than 10 years after the first Melanesian men had been brought to labour on the sugarcane fields of the Herbert. ${ }^{91}$ They were employed not only as housemaids but in the field, and described as executing the task 'very deftly'. ${ }^{92}$ As not all indentured labourers chose to return home at the end of their indenture, some continued on as timeexpired labour and a community of them formed a small village near the town of Halifax. Finlay Skinner wrote of how his mother always spoke of her admiration of the women of that village, and particularly of the three who 'adopted' her when, as a young mother, she spent long hours alone when her husband was working on the farm. They would be with her every day offering her help and companionship. ${ }^{93}$ However, not all Melanesian woman were automatically one of that community. Rachel Garlando writes that Annie would live out her life on the Herbert outside the experience of the rest of the Melanesian community. ${ }^{94}$

Annie's origins are clouded by inconsistent record keeping. Patricia Mercer calculates that the number of women and children transported as indentured labourers was few..$^{95}$ Annie's story suggests that some women may have entered the country identified as male. Annie's island of origin and her arrival date are unknown and over the period of her lifetime in various documents her geographic origins have been recorded differently. Similarly, her actual age cannot be verified. The only Etinside on the Pacific Island Immigration Queensland register was a male recruited

91 Robert Shepherd, 'The Herbert River Story: The Kanak Struggle', Herbert River Express, 23 January 1992, 5 [reprint, first published, 1957].

92 'Sugar Industry', Sydney Mail and New South Wales, 18 October 1884, 791.

93 Skinner, Memories of a First World War Digger, 19.

94 Garlando, 'Annie Gosling', 3.

95 Patricia Mary Mercer, 'The Survival of the Pacific Islander Population in North Queensland, 1900-1940' (PhD, The Australian National University, 1981), 10, 91. 
on 5 November 1888 from Ureparapara (the third largest island in the Banks group of northern Vanuatu) - the same island recorded on her headstone.${ }^{96}$ In family folklore, she was accompanied by a brother, though there is no official record confirming that. ${ }^{97}$ Among the local Australian South Sea Islander community there is even an assertion that she was the daughter of a Melanesian man and an Aboriginal woman and had been born on Palm Island. ${ }^{98}$ If she was 78 in 1948, as her death certificate states, and she was the 'male' recruited in 1888, then she would have been around 18 when she arrived in Australia. If she had been 67 years in Australia, again as recorded on her death certificate, she would have been indentured in 1881 and around 11 years old.

Female indentured labourers worked in the field and in settlers' homes. On arrival on the Herbert, Annie was indentured to Norwegian Johan (John) Ingebright Alm and his wife Antonia. ${ }^{99}$ Family recollections have her working for Englishman Francis Herron and his wife Lucinda. ${ }^{100}$ Both Alm and Herron were small farmers. Her next position was housemaid to the single George Gosling, another small farmer, who had migrated from Britain to Australia in $1881 .{ }^{101} \mathrm{He}$ had been an overseer of indentured labour gangs, farmed on leased land and then farmed in his own right a piece of land called Poverty Flat by the locals because it was considered useless for farming purposes. ${ }^{102}$ That he created a 'model farm' there was tribute to both Gosling and Annie's efforts, as small farmers depended on wives and children for all field labour apart from harvesting the cane. ${ }^{103}$

While housekeeping for Gosling, Annie would bear him two children. The birth records of her children are the first official record bearing the name Etenside (misspelt). Garlando speculates why they may have married in 1898 after the birth of the second child. ${ }^{104}$ In the absence of official indenture records Annie could have been identified as Aboriginal. Under the Aboriginal Protection and Restrictions of the Sale of Opium Act 1897, her movements and with whom she could associate would have been restricted

96 List of Pacific Island Labourers, LII-I 1865-1904, in Register of Pacific Island Immigration Queensland, QSA, image 23968.

97 Garlando, 'Annie Gosling', 8.

98 Ibid., 9.

99 'Obituary. The late Annie Gosling', Herbert River Express, 30 November 1948, 4.

100 Garlando, 'Annie Gosling', 8.

101 Ibid., 11.

102 'Halifax', Northern Miner, 18 August 1899, 8.

103 'Halifax', North Queensland Register (Trove), 21 August 1899, 48; Vidonja Balanzategui, 'Small Sugar Farmer Agency in the Tropics 1872-1914', 107-8.

104 Garlando, 'Annie Gosling', 14-19. 
and her children, as mixed race and born out of wedlock, could have been taken from her. ${ }^{105}$ Melanesian labour was never intended to be a permanent solution to the labour problem, nor were the Melanesian people to be permitted to settle permanently in Australia. ${ }^{106}$ Marriage to Englishman George Gosling gave her and her children protection. On the other hand, if identified as an indentured labourer, without the protection of marriage to Gosling, she and her children could have been forcibly repatriated. As early as 1892, the Queensland government indicated its intent to end indenture and repatriate those Melanesian labourers remaining in Queensland. Again, marriage to Gosling may have given her immunity. ${ }^{107} \mathrm{~A}$ further three children were born after their marriage. Then, on 17 January 1905, when the youngest was only eight days old, Gosling died of malaria. On his death Annie inherited land and goods worth $£ 1,700 .{ }^{108}$

In 1907 she gave birth to a baby she named Robert Gosling. Two years later she married William John Davey on 17 February 1909. Robert was likely to have been Davey's son. With Gosling's premature death, with a young family to support and a small farm to run, did she turn to William Davey, another European, for physical help on the farm? Tragically, one month after her marriage to Davey on 20 March 1909, she registered the death of Robert (providing no father's name). ${ }^{109}$ Davey was also dead by 30 August of the same year. ${ }^{110}$

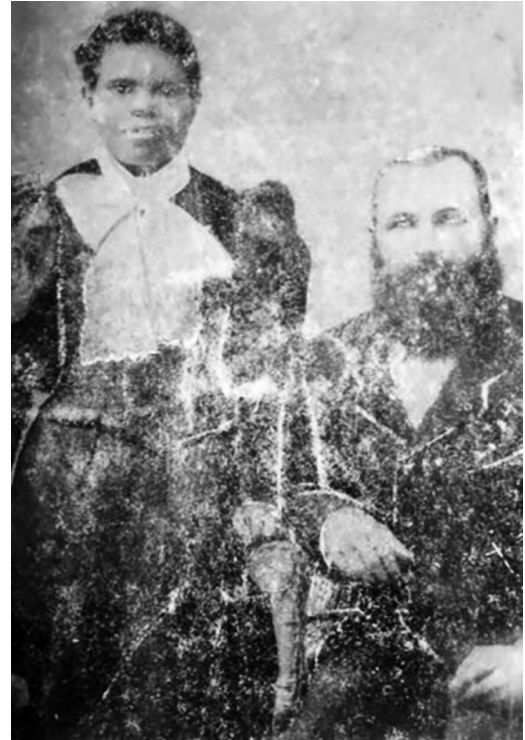

Figure 2: Annie Gosling (née Etinside Barslo) and George Gosling, 1885.

Source: Albert and Rachel Garlando.

105 Aboriginal Protection and Restrictions of the Sale of Opium Act 1897.

106 Vidonja Balanzategui, 'Small Sugar Farmer Agency in the Tropics 1872-1914', passim; Balanzategui, The Herbert River Story, 69-71.

107 Queensland Government, Pacific Island Labourers (Extension) Act, Qld, 1892.

108 'Returned', Morning Post (Trove), 12 July 1905, 2.

109 QRBDMD, registration details: 1909/C/620.

110 Ibid., 1909/C/531 and 1909/C/639. 
Tracey Banivanua-Mar states that settlement and economic development of tropical north Queensland by Europeans was rationalised by racial theories and attitudes that sanctioned violence, social segregation and ultimately forced repatriation. ${ }^{11}$ Those prevailing theories and attitudes may explain why Annie hid from her children that she was Melanesian with the result that her grandchildren had no idea they were descended from a Melanesian woman. Legislation dictated that only those former indentured labourers with a Certificate of Exemption could remain in Australia after 1907. Annie does not appear to have been granted a certificate of exemption, yet she remained and became a respected member of the Halifax community. Though her skin colour betrayed her as being other than white, she concealed or lost her heritage and her children were able to pass as white. Legal documents, the electoral role, newspaper reports, Annie's obituary and family accounts indicate that Annie did not experience the discrimination and prohibitions that other people of colour did. She inherited all of George's estate as his lawful widow and participated in civic life, was registered on the electoral role, and conducted a farm. Her children, meanwhile, all attended the Halifax State School, her male sons farmed and held jobs at the Colonial Sugar Refining Company (CSR) sugar mills (which was unusual for children of former indentured labourers), and her children married not only Anglo-Australians, but Europeans and Asians. ${ }^{12}$ Annie did 'not appear to be constrained by her ethnicity' as a Melanesian and was able to pass her children off as European. ${ }^{113}$ The cost, however, was her and her descendants' complete disassociation from the Melanesian community.

Annie's life was one of contradictions, and details of her life are elusive. There were fewer women indentured labourers on the Herbert than in other areas, so Annie could have easily found a partner from among the Melanesian community. ${ }^{114}$ Yet she did not. But as there were fewer white women to men on the Herbert perhaps it is not surprising that George

111 Tracey Banivanua-Mar, 'Stabilising Violence in Colonial Rule: Settlement and the Indentured Labour Trade in Queensland in the 1870s', Labour History, 113 (2017): 9-29; Tracey Banivanua-Mar, Violence and Colour: The Australian-Pacific Indentured Labour Trade (Honolulu: University of Hawai' $\mathrm{i}$ Press, 2007).

112 Mercer notes that as a migrant Annie would have had no voting rights and presumes that, as Annie Gosling disappeared from the electoral roll after 1908 when her name was first recorded, the authorities had caught up with the discrepancy. However, what Mercer missed was that Annie continued on the roll as Annie Davey.

113 Garlando, 'Annie Gosling', 20.

114 Mercer, 'Survival of a Pacific Islander Population', 78. 
Gosling married his Melanesian housekeeper. Though convenient for both, it could have been expected that he would face severe disapproval from the white community. Yet in Annie's obituary it is indicated that their relationship did not diminish opinions of him and rather he was remembered as 'well known and respected'. ${ }^{15}$ Meanwhile, forcible displacement meant that Annie had to live out her life apart from her own kin and family, resulting in a loss of heritage. Until the threat had passed, she had to live with the fear of forcible deportation. As a result, she determinedly raised her children as white in order to protect them from social rejection and racial slurs. So effective was she that on her daughter Elizabeth Rose's wedding to Frederico Garlando in 1925, a detailed report of the wedding featured in both the Herbert River Express (HRE) and the Townsville Bulletin. ${ }^{116}$ When Annie died on 23 November 1948 she was legally Annie Davey, though after Davey's death she reverted to Gosling and her obituary in the HRE was for the late Annie Gosling. There she was described as a 'grand old pioneer'. ${ }^{117}$ Annie's intriguing story adds a female dimension to the Melanesian indentured labourer's experience on the Herbert. The number of Melanesian labourers on the Herbert as repatriation measures came into force in 1906 were 14 Melanesian women and 500 men. ${ }^{118}$ The significance of having such a fulsome account of her life is underscored by the small number of Melanesian women who were recruited to the Herbert and, in turn, remained there. Her story illustrates how one Melanesian woman living on the Herbert in the plantation era attempted to determine a life for herself and her children through accommodation of male-dominated white cultural and economic practices.

\section{Eliza}

Eliza Jane Ah Bow and Annie would have undoubtedly recognised each other as they passed in the main street of Halifax. Like Annie, Eliza, who was the daughter of a Chinese father and an Irish mother, was caught between two cultures. Large numbers of Chinese men were employed on the sugar plantations on the Herbert in the 1880s, supplementing the Melanesian indentured labour force. The majority came from rural

115 'Obituary: The Late Annie Gosling', 4.

116 'Family Notices Wedding Garlando-Gosling', Townsville Daily Bulletin (Trove), 4 December $1925,7$.

117 'Obituary: The Late Annie Gosling', 4.

118 Mercer, 'Survival of the Pacific Islander Population', 78. 
communities in the Guangdong Provence in the Southern Pearl Delta. ${ }^{119}$ In 1884 there were as many as 640 employed by the sugar mills, and by 1885 the Chinese population on the Herbert was described as 'numerous and prosperous'. ${ }^{120}$ Included were 25 Chinese families. ${ }^{121}$ Chinatowns were established at Cowden (Wickham's property) with commercial centres in East Ingham and in Halifax. ${ }^{122}$ Not only did the men labour for others, they were also market gardeners, shopkeepers and sugar farmers in their own right. But the Herbert was dominated by sugar growing and there was little agricultural diversification, so the bulk of the Chinese population was engaged in the industry as employees or as farmers. With the restrictions imposed by the White Australia Policy legislation (1901) and the Sugar Bounty Acts (1903 and 1905), which mandated that sugar be grown and harvested using only white labour, Chinese people were essentially forced off the Herbert. ${ }^{123}$ Europeans on the Herbert would not have normally acknowledged the Chinese residing there as 'pioneers'; however, Alec S Kemp, an early resident on the Herbert, listed both Chinese and Europeans settlers as pioneers in his memoir. In an unusual sentiment for a European in the time, he wrote that 'its [sic] a pity they left the area'. ${ }^{124}$ He described in detail the Joss House in Halifax and the shops that were 'a wonderland of enchantment for child and adult alike'. He recalled, 'the lovely little sloe eyed girls, "like lovely little frightened fawns", dressed in their picturesque chinese [sic] costumes, helping to serve when times were busy'. ${ }^{125}$

The girls Kemp described were likely to have been born in Australia of mixed marriages, as wives and children of married men remained behind in China, often never to be seen again. ${ }^{126}$ The first Chinese-born woman to settle on the Herbert did so in $1911 .{ }^{127}$ Chinese men married white migrant women, but they endeavoured to marry their daughters to fellow

119 Sandi Robb, 'Chinese Families', Exhibition banner in Rediscovering Buk Ti: Chinese settlers in the lower Herbert Valley (Ingham Family History Association Inc: Exhibition February 2019).

120 Pugh's Almanac and Queensland Directory (Brisbane: Gordon \& Gotch, 1884); 'A Winter Tour in Queensland', Argus (Trove), 24 October 1885, 4.

121 Robb, 'Chinese Families'.

122 Jan Wegner and Sandi Robb, 'Chinese in the Sugar: A Case Study from the Ingham District', in Northern Links: Chinese in Tropical Australia, eds. Sandi Robb and Kevin Rains (Ipswich: Chinese Heritage in Northern Australia (CHINA) Inc., 2014), 8-9; Gossner and Robb, 'Lee Hop'.

123 Wegner and Robb, 'Chinese in the Sugar', 11-13.

124 Kemp, The Kemp Report, 27.

125 Ibid.

126 Robb, 'Chinese Families'.

127 Gossner and Robb, 'Mar Gee'. 
Chinese. ${ }^{128}$ James Ah Bow married Irish immigrant Ellen Bridget O’Daly in Townsville in 1875, where their four children were born. On their move to Chinatown at Cowden, James ran a market garden. ${ }^{129}$ There their son Patrick went to school, though it is unclear whether their daughters ever did. The girls did, however, lead active social lives. ${ }^{130}$

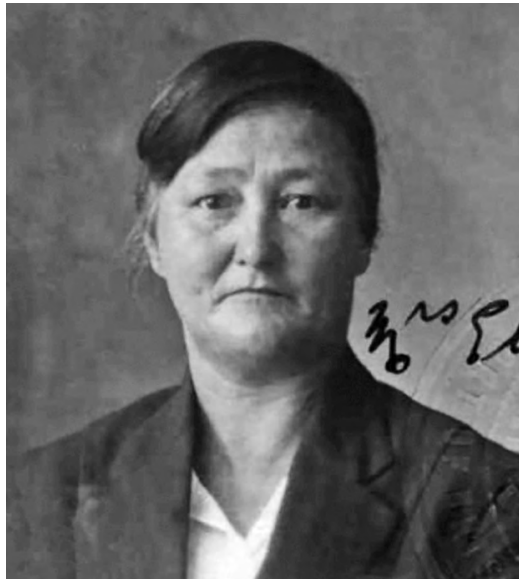

Figure 3: Elizabeth Jane Look Hop (née Ah Bow) 1925.

Source: National Archives of Australia, NAA: Series no. J2483, 391/45, Certificate Exempting from Dictation Test (CEDT), 14 November 1925.
At some point, Eliza Jane, the oldest daughter, met Lee Look Hop (Thomas Look Hop). On arrival in Queensland, Thomas was drawn by the gold rush to the Palmer River, later moving to the lower Herbert where he opened a shop behind the Planter's Retreat. ${ }^{131}$ His neighbours were the Ah Bow family. It is not recorded how his marriage to Eliza was arranged or if she was complicit. What is known, however, is the fact that Eliza was already pregnant before the marriage and Thomas was a prominent eligible man in Chinatown. ${ }^{132}$ Eliza married Thomas at the Planter's Retreat on 5 June $1891 .{ }^{133}$ She was only 13 years of age, though she was recorded as 14 on the marriage record. ${ }^{134}$ Four months after her marriage she gave birth to her first child at home. ${ }^{135}$ At the age of 18 she lost both her parents, at 19 she lost a younger sister, and at the age

128 Robb, 'Chinese Families'.

129 Gossner and Robb, 'Ah Bow'.

130 Ibid.

131 Gossner and Robb, 'Lee Look Hop'.

132 Ibid.

133 QRBDMD, registration details: 1891/C/352.

134 Ibid., 1878/C/5247; Gossner and Robb, 'Lee Look Hop'. Further information on Eliza can also be obtained through the records of Hinchinbrook Shire Council cemetery.

135 QRBDMD, registration details: 1891/C/2227. 
of 21, in 1899, she left on the first of her trips to China. ${ }^{136}$ Travelling with her and Thomas were their five children (the youngest being eight months). ${ }^{137}$ In China they lived in the village of Loong Dou, Zhongshan, where they remained until 1909. ${ }^{138}$ On their return to the Herbert, she gave birth to four more children the youngest of whom was only six months old when Thomas died in 1912. ${ }^{139}$ Two years later she gave birth to another child, Cornelius Daly Lee (the surname having been shortened from Look Hop to Lee). No father was recorded. ${ }^{140}$ She outlived her husband by 49 years, dying in Townsville on 27 August 1961 as Elizabeth Jane Lee. ${ }^{141}$ Her children retained strong connections with the village and family in China, some living their adult lives there, others visiting for lengthy periods or, in the case of James, her first son, balancing both countries and their customs. ${ }^{142} \mathrm{He}$ maintained a large house in China and had two wives, which he brought to Australia after the Second World War. ${ }^{143}$

In her lifetime, Eliza demonstrated pluck, a sense of adventure, sustained hard work and persistence, no less so than the Chinese men we know so much more about. Eliza endured much from a very young age, beginning with marriage to an older man and childbirth when she was still a child. She experienced frequent childbearing and suffered the death of her mother and sister when she most needed them. She fearlessly faced the perils of nineteenth-century sea travel with children, including an infant, and life in a foreign country far distant from the Herbert and her brother and sister. Her husband's early death left her with a young family to support and yet she survived all that to live to 83 years of age. Where the Chinese experience is invariably recorded in terms of the men's contribution to the sugar industry and commerce, Eliza's life story offers a more nuanced version of the Chinese experience on the Herbert in the plantation era.

136 Gossner and Robb, 'Lee Look Hop'.

137 Ibid.

138 Gossner and Robb, 'Ah Bow'.

139 QRBDMD, registration details: 1911/C/2143, 1912/C/710.

140 QRBDMD, registration details: 1914/C/2442.

141 Ibid., 1961/C/4636. Further information can also be obtained through the records of Belgium

Gardens Cemetery, Townsville.

142 Gossner and Robb, 'Lee Look Hop'.

143 Ibid. 


\section{Conclusion}

In this article, the lives of these women who lived in the Herbert Valley during the plantation era of the late nineteenth century have been fleshed out, informed by the often two-dimensional descriptions given by European men, and supplemented by the few records left by women themselves, and other primary sources and secondary scholarship. Theirs was an invisible narrative running parallel to the well-documented one of men's exploits; their stories add to our knowledge of the gender history of this period and challenge the notion of the frontier as an entirely masculine landscape. When they appear in the primary accounts of men, they do so briefly and are often regarded with pity if they are white or contempt if they are coloured. With this account, a group of women, white and of colour, living alongside each other in plantation-era tropical north Queensland have been identified and their contributions rightly acknowledged; they were not bystanders and observers, and were certainly not pitiable or contemptible. Rather, they were strong, active participants in, and survivors of, the drama of colonisation that opened the Herbert to white settlement, displaced the Indigenous land owners, and melded cultures from across the globe. 


\title{
Unnatural Womanhood: Moral Treatment, Puerperal Insanity and the Female Patients at the Fremantle Lunatic Asylum, 1858-1908
}

Alexandra Wallis

University of Notre Dame Australia

\begin{abstract}
Puerperal insanity, or what might be understood as a form of postnatal depression, was the third most frequent diagnosis among the women of the Fremantle Lunatic Asylum from 1858 to 1908 . The emphasis society placed on pregnancy and child-rearing as women's primary function resulted in anxieties surrounding childbirth. Modern medical professionals are now aware there are several factors involved in postnatal depression. However, nineteenth-century physicians viewed it as a common issue of 'mental derangement' in women soon after childbirth, but unlikely to be permanent. To treat this, Fremantle Asylum physicians instituted moral treatment methods, including domestic work as rehabilitation. As this paper demonstrates, this form of rehabilitation reinforced the conventional feminine behaviours essential for functioning wives and mothers in nineteenth- and early twentieth-century society. As women suffering puerperal insanity challenged the notions of domesticity and femininity, their experiences allow for an analysis of how moral treatment was implemented in Fremantle. Through the patient records and case books of the Fremantle Asylum, this paper reveals that moral treatment did not cure all patients, leaving some susceptible to readmission and continued mental illness.
\end{abstract}


Alice Mary Anderson was a 27-year-old Roman Catholic housewife admitted to the Fremantle Lunatic Asylum on 30 December 1901 diagnosed with 'puerperal melancholia' caused by childbirth and with 'general symptoms of puerperal mania'. ${ }^{1}$ One month before Alice's admission, she had given birth to a daughter, Kathleen Maud. ${ }^{2}$ However, her husband, Charles, reported Alice had threatened to poison herself, and the day before admission 'she attempted to get away to drown herself in the river. She also attempted to take hold of a knife. Later she took her boots off in the street in order that she might walk across broken glass. ${ }^{3}$ In the asylum, Medical Superintendent Dr Sydney Hamilton Rowan Montgomery observed Alice was 'very restless and excited, weeps and bemoans all days, says she is lost forever'. ${ }^{4}$ Eight days later, on 7 January 1902, Montgomery noted that Alice was 'still very depressed' and 'will not speak or employ herself'. ${ }^{5}$ However, towards the end of January, she was 'rather better, has started to do a little sewing' but was 'still depressed'. ${ }^{6}$ Approximately one month later, on 14 February, Montgomery reported that Alice was 'improving, is more cheerful and contented'. 7 By the end of February, Alice was considered convalescent, and on 22 March 1902, she was 'discharged recovered', after three months in the asylum. ${ }^{8}$ Alice's depressed responses after childbirth manifested as suicidal actions that resulted in her committal.

Puerperal insanity was a nineteenth-century understanding of postnatal depression, although not understood or treated as it is today. ${ }^{9}$ It was not uncommon for a diagnosis to include both puerperal melancholia and

1 Thanks to my supervisor Leigh Straw for her advice and support, Deborah Gare, Joan Wardrop and the Notre Dame postgraduate crew for their encouragement and feedback, in particular, to Toni Church for her comments on this article. I would also like to acknowledge the State Records Office of Western Australia (SROWA) for their assistance in accessing records. This research has been carried out with the aid of an Australian Postgraduate Award (APA). SROWA: Case Book Female Patients, 1901-08, Folio 13, 30 December 1901.

2 Ibid.; The Births, Deaths, and Marriages Index of Western Australia (BDMWA): Certificate of Birth, Kathleen Maud Anderson (1543/1901).

3 Certificate of Birth, Kathleen Maud Anderson (1543/1901).

4 SROWA: Case Book Female Patients, Folio 14, 30 December 1901. Dr Montgomery was Medical Superintendent 1901-08.

5 Ibid., 7 January 1902

6 SROWA: Case Book Female Patients, Folio 14, 21 January 1902.

7 Ibid., 14 February 1902.

8 Ibid., 28 February; 22 March 1902.

9 A direct comparison between puerperal insanity and postnatal depression is not overly beneficial; this paper does not intend to retrospectively diagnose the women of Fremantle. 
puerperal mania, as the words were used interchangeably. ${ }^{10}$ Puerperal mania was the most common form of puerperal insanity found in asylums and was an acute and sudden onset of mania. ${ }^{11}$ The treatment for Alice was similar to that of the other women admitted to the Fremantle Lunatic Asylum: moral treatment. Alice was prescribed the domestic task of sewing, which she initially refused to do, although she eventually took well to the task. Alice was a success of moral treatment as her behaviour was perceived to be improved and she had regained some sanity through the domestic tasks. However, Alice's case also reveals that although she was discharged, she may still have been suffering from various mental illnesses and quite possibly did not receive adequate help for her situation.

This paper will examine the implementation of moral treatment in the Fremantle Lunatic Asylum from 1858 to 1908, through the cases of the women admitted with puerperal insanity. ${ }^{12}$ The examination of the female patient records will reveal that moral treatment reinforced nineteenthand early twentieth-century gender expectations for women through domestic chores and socially appropriate behaviours for women. Thus, the analysis of puerperal insanity patients determined the underdeveloped institutional and social understandings of postnatal depression in colonial Fremantle. The paper concludes that while moral treatment and domestic rehabilitation provided useful chores for women in the asylum, this method alone failed to provide the help that the women needed or to treat underlying psychological issues. Thus, it left women vulnerable to readmission and the potential for continued mental illness.

This research will contribute to existing historical scholarship on puerperal insanity and moral treatment, to aid in understandings in the development of attitudes and treatment methods regarding postnatal depression. The paper is shaped by wider research into the experiences of the female patients at the Fremantle Lunatic Asylum. As such, this paper provides original data on puerperal insanity and adds analysis of Fremantle Asylum patient notes to gendered Australian asylum historical scholarship.

10 I Loudon, 'Puerperal Insanity in the 19th century', Journal of the Royal Society of Medicine, 81 (1988): 76.

11 Ibid. See Table 1.1 for details of Fremantle asylum diagnosis.

12 SROWA: Case Book Female Patients, 1878-97; AU WA S2219, Cons 2724 03; Case Book Female Patients, 1901-08; AU WA S2219 Cons 3100 01; Case Book Female Patients, 1906-08; AU WA S2219 Cons 2724 04; Case Book Female Patients Chronic Medical Conditions, 1901-08; AU WA S2219, Cons 3103 01; Female Register Fremantle Lunatic Asylum Case Book, 1873-78; AU WA S2219, Cons 5759 1; Register of Female Patients, 1858-73; AU WA S507, Cons 1120 04. These dates have been selected according to the time the asylum was in operation in Fremantle. 


\section{Moral Treatment}

Inspired by the Enlightenment, nineteenth-century physicians began to revolutionise asylum treatment. The development from this period was moral treatment. Moral treatment originated in England when William Tuke founded the York Retreat in 1796. The founder's grandson Samuel Tuke wrote in 1813 that intellectual, active, and moral power, are usually rather perverted than obliterated' in cases of insanity; with moral instruction, they could be cured. ${ }^{13}$ Moral treatment aimed to enforce 'good' habits in patients to teach them how to be good citizens; therefore the asylum had to reinforce skills according to gender, including social norms and work. ${ }^{14}$ Louise Hide notes that moral treatment was seen as an advancement in humanitarian asylum treatment. ${ }^{15}$ However, as Michel Foucault argued, moral treatment 'symbolized the massive structures of bourgeois society in its values. ${ }^{16}$ Thus, Foucault saw moral treatment as moral imprisonment. ${ }^{17}$

In colonial Western Australia, moral treatment governed asylum methods. ${ }^{18}$ The Fremantle Lunatic Asylum was constructed from 1861 and opened in $1865 .{ }^{19}$ Although designed for the Fremantle community, the asylum was at capacity ( 28 men and 17 women) when it officially opened..$^{20}$ These admission numbers were a sign of chronic overcrowding in Fremantle, which was a constant complaint in the medical superintendent's annual reports. ${ }^{21} \mathrm{~A}$ common issue for physicians who implemented moral treatment was overcrowding. Overcrowding created

13 Samuel Tuke, A Description of the Retreat: An Institution Near York for Insane Person of the Society of Friends (London: Dawson, 1813), 134.

14 Elaine Showalter, The Female Malady: Women, Madness and English Culture 1830-1980 (London: Virago Press, 1987), 31.

15 Louise Hide, Gender and Class in English Asylums, 1890-1914 (Hampshire: Palgrave Macmillian, 2014).

16 Michel Foucault, Madness and Civilization: A History of Insanity in the Age of Reason, trans. Richard Howard (Oxon: Routledge, 2001), 260.

17 Suzanna M Peloquin, 'Moral Treatment: Contexts Considered', The American Journal of Occupational Therapy, 43, no. 8 (1989): 524.

18 Indigenous peoples are the traditional custodians of Western Australia with a history spanning 40,000-60,000 years and the Whadjuk Noongar are custodians of the land in Fremantle.

19 Jane Hall, May They Rest in Peace: The History and Ghosts of the Fremantle Asylum (Carlisle, WA: Hesperian Press, 2013), v-5. The Harbourmaster Daniel Scott's warehouse was used as a temporary asylum from 1857 , admitting women from 1858 . These patients were transferred to the permanent building from 1864 .

20 Hall, May They Rest in Peace, 6.

21 Ibid. The difference in male and female population demographics during this period could account for the male patients usually outnumbering the female patients. 
difficulties in providing individualised care, and leisure rooms were used as sleeping quarters. ${ }^{22}$ Thus, Fremantle sometimes struggled to institute moral treatment ideals.

The first of the Fremantle medical superintendents, Dr George Attfield, emphasised human nature in the care for the mentally ill. ${ }^{23}$ In order to implement moral treatment he supplied amusements such as books, ball games and draughts in the evening. ${ }^{24}$ However, under his care, women's amusement constituted washing, sewing and housework. ${ }^{25}$ Female patients were not forbidden to engage with those amusements; nevertheless, domestic tasks were the primary amusements for women. The succeeding medical superintendent, Dr Henry Calvert Barnett, created Rules for the Guidance of Attendants (1872), which embraced the idea of moral care and emphasised the notions of 'Gentleness, Firmness, Tolerance'. ${ }^{26}$ Barnett's rules reflected moral treatment techniques: patients were to be employed and active, and attendants were not to use physical intimidation or harm in their overall humane treatment of patients. ${ }^{27}$ In his 1889 report, Barnett wrote that 'the male patients are occupied in gardening, cutting firewood, pumping water, cooking, cleaning the premises, etc., and the women do all the washing, and make their own clothing'. ${ }^{28}$ Thus, medical superintendents made a clear link between women's amusement and domestic chores.

To examine the use of moral treatment in Fremantle, this paper analyses a particularly gendered experience of madness: puerperal insanity. Nineteenth-century physicians believed that childbirth had links to insanity. ${ }^{29}$ In 1835, Dr James Cowles Prichard argued that puerperal madness was a form of mental 'derangement' in women soon after childbirth, and it would often end in death or the quick recovery of

22 Peloquin, 'Moral Treatment', 542.

23 Phil Maude, 'Treatment of Western Australia's Mentally Ill During the Early Colonial Period, 1826-1865', Australasian Psychiatry, 21, no. 4 (2013): 400-1, doi.org/10.1177/1039856213492863. Dr Attfield was Medical Superintendent from 1858-70.

24 Maude, 'Treatment of WA Mentally Ill', 400.

25 Ibid.

26 Philippa Martyr, 'Unlikely Reformer: Dr Henry Calvert Barnett (1832-1897)', Australasian Psychiatry, 25, no. 5 (2017): 498, doi.org/10.1177/1039856217715992. Dr Barnett was Medical Superintendent 1872-97.

27 Henry Calvert Barnett, Rules for the Guidance of Attendants, Fremantle Lunatic Asylum, 1872, Lunatics (Folios 12-106), SROWA, AU WA S2941-cons36, item 721.

28 Henry Calvert Barnett, Report Upon the Lunatic Asylum at Fremantle, for the Year 1889, by the Surgeon Superintendent (Perth: Richard Pether, Government Printer, 1890), 5.

29 Loudon, 'Puerperal Insanity', 76. 
reason. ${ }^{30}$ Hilary Marland writes that physicians recognised puerperal insanity as so common that it was almost an 'anticipated accompaniment of the process of giving birth'. ${ }^{31}$ James De Burgh Griffith, medical officer at Yarra Bend Asylum, Victoria, wrote in 1882, 'I do not know anything more alarming to a family circle, or more trying to the medical attendant. All that seemed bright has suddenly become changed, and instead of joy there has come unmeasured trouble. ${ }^{32}$ Therefore, hospitals did not always have the time or facilities to treat these patients, and they were sent to asylums. However, Griffith added that 'the friends of the patient shrink from the idea of sending her to an asylum for the insane, and indeed, will endure such trouble before they adopt such a course'. ${ }^{33}$ Griffith, and others, believed puerperal insanity could be well treated at home, thus those women sent to asylums were very unwell or even violent. ${ }^{34}$

The women who were diagnosed with puerperal insanity were perceived by medical professionals and society as the opposites of 'good' women, rejecting or struggling with the important role of motherhood. Jill Julius Matthews argues, in her study of the Glenside Hospital in South Australia during the twentieth century, that case notes revealed some women had 'suffered no illness till after the birth of a child'. ${ }^{35}$ Whether their mental illness was perceived to be directly caused or exacerbated by parturition, moral treatment was applied to these women. Morag Allan Campbell notes that a focus on puerperal insanity patients can obscure the fact that all female patients were expected to adhere to the ideal female role. ${ }^{36}$ Moral treatment in Fremantle was not exclusive to puerperal patients and was used across all diagnoses and genders. ${ }^{37}$ However, women diagnosed with puerperal insanity offer a unique insight into the gendered experience of diagnosis and treatment in a nineteenth-century asylum.

30 James Cowles Prichard, A Treatise on Insanity and Other Disorders Affecting the Mind (London: Sherwood, Gilbert, and Piper, 1835), 306, doi.org/10.1037/10551-000.

31 Hilary Marland, Dangerous Motherhood: Insanity and Childbirth in Victorian Britain (Hampshire: Palgrave Macmillan, 2004), 5.

32 James De Burgh Griffith, 'Puerperal Insanity', Australian Medical Journal, iv, no. 6 (June 1882): 241.

33 Ibid.

34 Ibid.

35 Jill Julius Matthews, Good and Mad Women: The Historical Construction of Femininity in Twentieth Century Australia (North Sydney, NSW: George Allen \& Unwin Publishers, 1984), 178.

36 Morag Allan Campbell, "Noisy, Restless and Incoherent": Puerperal Insanity at Dundee Lunatic Asylum', History of Psychiatry, 28, no. 1 (2017): 54, doi.org/10.1177/0957154x16671262.

37 Moral treatment in the Fremantle Asylum is examined in greater detail in the author's PhD thesis. 


\section{Puerperal Patients in the Fremantle Lunatic Asylum}

In Fremantle, 62 women were admitted to the asylum for puerperal insanity. As seen in Table 1.1, the total number of puerperal insanity patients admitted was 13.7 per cent of the total asylum population from 1858 to 1908 (452 patients in total). ${ }^{38}$ The context of all female admissions to Fremantle reveals that the most frequent recorded diagnosis was delusions at 24 per cent, 19 per cent with mania, 12.4 per cent with dementia and 10.8 per cent with melancholia. Thus, puerperal insanity was the third-highest identified reason for admission to the Fremantle Asylum. On admission there were often different terms used for diagnosis resulting in 73 terms written into the case books. The many terms could be due to the fact that puerperal insanity was, at times, a convenient diagnosis for women, with physicians eager to find labels that were applicable for their patients. ${ }^{39}$ Joan Busfield argues that the category was imprecise and often referred to anything from pregnancy to years after confinement. ${ }^{40}$ Thus, in Fremantle, different puerperal terms were used interchangeably.

Table 1.1: Puerperal Insanity Terms Used on Admission to the Fremantle Lunatic Asylum (1858-1908)

\begin{tabular}{|l|r|r|r|r|r|r|r|r|}
\hline & $\mathbf{1 8 5 8 -}$ & $\mathbf{1 8 7 3 -}$ & $\mathbf{1 8 7 8 -}$ & $\mathbf{1 9 0 1 -}$ & $\mathbf{1 9 0 1 -}$ & $\mathbf{1 9 0 6 -}$ & Total & \% \\
\hline Puerperal mania & 1 & 1 & 5 & - & 12 & 7 & $\mathbf{2 6}$ & $\mathbf{4 2 \%}$ \\
\hline Pregnancy & 2 & 1 & - & - & 4 & 2 & $\mathbf{9}$ & $\mathbf{1 4 . 5 \%}$ \\
\hline Lactation & - & - & 1 & 1 & 5 & 1 & $\mathbf{8}$ & $\mathbf{1 3 \%}$ \\
\hline Miscarriage & - & - & - & - & 4 & 3 & $\mathbf{7}$ & $\mathbf{1 1 . 3} \%$ \\
\hline Death of children & - & - & - & - & 2 & 2 & $\mathbf{4}$ & $\mathbf{6 . 4 \%}$ \\
\hline Childbirth & - & - & - & - & 2 & 2 & $\mathbf{4}$ & $\mathbf{6 . 4 \%}$ \\
\hline $\begin{array}{l}\text { Attempted harm } \\
\text { of child }\end{array}$ & - & - & 2 & - & 1 & - & $\mathbf{3}$ & $\mathbf{4 . 8} \%$ \\
\hline Abortion & - & - & - & - & 2 & - & $\mathbf{2}$ & $\mathbf{3 . 2} \%$ \\
\hline $\begin{array}{l}\text { Puerperal } \\
\text { melancholia }\end{array}$ & - & - & - & - & 2 & - & $\mathbf{2}$ & $\mathbf{3 . 2} \%$ \\
\hline
\end{tabular}

38 These statistics are based on the SROWA sources and the dates listed correspond to the case books: see footnote 13 . The percentages for Table 1.1 are the total number of admissions that relate to puerperal insanity.

39 Marland, Dangerous Motherhood, 105.

40 Joan Busfield, Men, Women and Madness: Understanding Gender and Mental Disorder (London: MacMillan Press Ltd, [1996] 2005), 159. 


\begin{tabular}{|c|c|c|c|c|c|c|c|c|}
\hline & $\begin{array}{c}1858- \\
1873\end{array}$ & $\begin{array}{c}1873- \\
1878\end{array}$ & $\begin{array}{c}1878- \\
1897\end{array}$ & $\begin{array}{c}1901- \\
1908\end{array}$ & $\begin{array}{l}1901- \\
1908\end{array}$ & $\begin{array}{c}1906- \\
1908\end{array}$ & Total & $\%$ \\
\hline Puerperium & - & - & - & - & 1 & - & 1 & $1.6 \%$ \\
\hline Premature baby & 1 & - & - & - & - & - & 1 & $1.6 \%$ \\
\hline Infanticide & 1 & - & - & - & - & - & 1 & $1.6 \%$ \\
\hline Puerperal insanity & - & - & 1 & - & - & - & 1 & $1.6 \%$ \\
\hline $\begin{array}{l}\text { Neglect of nurse } \\
\text { in confinement }\end{array}$ & - & - & - & - & - & 1 & 1 & $1.6 \%$ \\
\hline Postpartum & - & - & - & - & - & 1 & 1 & $1.6 \%$ \\
\hline $\begin{array}{l}\text { Demented after } \\
\text { confinement }\end{array}$ & - & - & 1 & - & - & - & 1 & $1.6 \%$ \\
\hline Not herself after birth & - & - & - & - & - & 1 & 1 & $1.6 \%$ \\
\hline $\begin{array}{l}\text { Total times } \\
\text { terms used }\end{array}$ & 5 & 2 & 10 & 1 & 35 & 20 & 73 & - \\
\hline $\begin{array}{l}\text { Total number of } \\
\text { women admitted for } \\
\text { puerperal reasons }\end{array}$ & 5 & 1 & 10 & 1 & 27 & 18 & 62 & $13.7 \%$ \\
\hline
\end{tabular}

Note: The percentages are based on the total number of women admitted for puerperal reasons. However, the $13.7 \%$ figure is based on the total number of female patients admitted across 1858 to 1908.

Source: Author's research.

The individuals who admitted the 62 women included those with a professional responsibility for the patient and those with a personal relationship, as seen in Table 1.2. The majority, 69.3 per cent, were admitted by professionals including doctors, regional magistrates or Justices of the Peace. Another 30.6 per cent were admitted by their male relatives, of which 26 per cent were their husbands. These statistics are consistent with the general female patient statistics in which most women were also admitted by professionals at 61.5 per cent, and 19 per cent were admitted by a male relative, of which 11.7 per cent were husbands. This reveals that admission of women with puerperal insanity to the Fremantle Asylum was decided amongst male professionals and male family members.

Table 1.2: Persons Who Admitted Female Patients to the Fremantle Lunatic Asylum (1858-1908)

\begin{tabular}{|l|r|r|r|r|r|r|r|r|r|}
\hline & $\begin{array}{c}\text { Drs/ } \\
\text { RM/JP }\end{array}$ & Husband & $\begin{array}{c}\text { Medical } \\
\text { Board }\end{array}$ & Brother & Son & Father & Friend & Mother & N/A \\
\hline Total & 43 & 16 & 2 & 1 & 1 & 1 & 1 & 1 & 1 \\
\hline$\%$ & $69.3 \%$ & $26 \%$ & $3.2 \%$ & $1.6 \%$ & $1.6 \%$ & $1.6 \%$ & $1.6 \%$ & $1.6 \%$ & $1.6 \%$ \\
\hline
\end{tabular}

Note: If admitted twice by the same person it was counted once.

Source: Author's research. 
The patient registers and case books from 1858 to 1908 also provide a greater picture of the kinds of women that were admitted to the asylum, through their age, marital status, religious denomination, occupation and nationality. As puerperal insanity was a postpartum mental illness, it is no surprise that the women who were admitted were of childbearing age, most were aged between 20 to 39 years old (76 per cent). ${ }^{41}$ This statistic is slightly higher than the general female asylum age range (which was 55.5 per cent for those between 20 and 39), although this was still the highest category.

The marital status of the women admitted for puerperal reasons is evidenced in Table 1.3. This data reveals that women admitted for puerperal reasons were overwhelmingly married, at 87 per cent. However, overall, married women constituted only 45 per cent of all female patients admitted from 1858 to $1908 .{ }^{42}$ Thus, it can be suggested that more married women were identified as having puerperal symptoms than single women. Pat Jalland notes that in colonial Australia many convicts and early migrants were obliged to confront illness and destitution without the support of family networks or traditional communities, until new family formation took place over generations. ${ }^{43}$ The lack of familial support would be further isolating for single mothers. It is also possible that single mothers perhaps received different diagnoses that were not associated with puerperal insanity as they may have kept their pregnancies secret.

Table 1.3: Marital Status of Puerperal Patients in Fremantle Lunatic Asylum (1858-1908)

\begin{tabular}{|l|r|r|r|r|r|r|}
\hline & \multicolumn{1}{|c|}{ Married } & \multicolumn{1}{c|}{ Single } & \multicolumn{1}{|c|}{ Widow } & $\begin{array}{l}\text { Married/ } \\
\text { Widow }\end{array}$ & $\begin{array}{l}\text { Single/ } \\
\text { Married }\end{array}$ & \multicolumn{1}{c|}{ N/A } \\
\hline Total & 54 & 2 & 1 & 1 & 2 & 2 \\
\hline$\%$ & $87 \%$ & $3.2 \%$ & $1.6 \%$ & $1.6 \%$ & $3.2 \%$ & $3.2 \%$ \\
\hline
\end{tabular}

Note: Married/Widow = Married then later noted as widowed in a readmission. Single/ Married $=$ Single and then later noted as married in a readmission.

Source: Author's research.

41 Total percentages for the age of puerperal patients on admission: 10-19 (1.6 per cent), 20-29 (46.7 per cent), 30-39 (29 per cent), 40-49 (7.7 per cent), 50-59 (3.2 per cent), unknown (1.6 per cent).

42 Marital status of all female patients from 1858 to 1908: married 45 per cent, single 24.5 per cent, widowed 8.8 per cent, married/widowed 1.3 per cent, single/married 0.88 per cent, and 19.5 per cent were unknown.

43 Pat Jalland, Old Age in Australia: A History (Melbourne: Melbourne University Press, 2015). 
Table 1.4 details the various religious denominations of the women admitted for puerperal reasons, of which Protestant faiths were the most frequent at 55 per cent. This statistic is also slightly higher than the general statistic for religion, which was 40.5 per cent in total. Thus, religion must not have been a significant factor in admission, as it was reasonably consistent with general female admissions.

Table 1.4: Religious Denominations of Puerperal Patients in Fremantle Lunatic Asylum (1858-1908)

\begin{tabular}{|l|r|r|r|r|r|r|r|}
\hline & $\begin{array}{c}\text { Roman } \\
\text { Catholic }\end{array}$ & $\begin{array}{c}\text { Church of } \\
\text { England }\end{array}$ & Anglican & Presbyterian & Methodist & Wesleyan & N/A \\
\hline Total & 13 & 9 & 11 & 6 & 3 & 4 & 11 \\
\hline$\%$ & $21 \%$ & $14.5 \%$ & $17.7 \%$ & $9.6 \%$ & $4.8 \%$ & $6.5 \%$ & $17.7 \%$ \\
\hline \multicolumn{2}{|l}{ One each was listed for Protestant, Jewish, Catholic, Church of Christ and Baptist. } \\
\hline
\end{tabular}

Source: Author's research.

As detailed in Table 1.5, the occupations for puerperal women were most commonly housewife or housework, with 50 per cent of puerperal patients considered to be housewives. However, 22.6 per cent were also employed beyond the home, most commonly in domestic service. The puerperal patients' statistics are not dissimilar to the general female patients, of which 23.6 per cent were in domestic work and 21 per cent were listed as housewives; a further 47.3 per cent had no occupation identified. However, puerperal patients were identified more as housewives than were general female patients. This is not to say that because these women were mothers they did not also have paid employment; however, it does reveal that it was generally women who were working within their homes, juggling domestic duties and child-rearing, that were admitted to Fremantle for puerperal reasons.

Table 1.5: Occupations Listed for Puerperal Patients in Fremantle Lunatic Asylum (1858-1908)

\begin{tabular}{|l|r|r|r|r|r|r|}
\hline & Housework & Housewife & $\begin{array}{c}\text { Domestic } \\
\text { Service }\end{array}$ & Tailoress & $\begin{array}{l}\text { School } \\
\text { Teacher }\end{array}$ & N/A \\
\hline Total & 17 & 14 & 11 & 2 & 1 & 17 \\
\hline$\%$ & $27.4 \%$ & $22.6 \%$ & $17.7 \%$ & $3.2 \%$ & $1.6 \%$ & $27.4 \%$ \\
\hline
\end{tabular}

Source: Author's research. 
Lastly, the nationalities of the patients were also recorded on admission. As seen in Table 1.6, the largest percentage of women admitted were from Victoria and, overall, most were of Australian origin at 46.7 per cent. $^{44}$ The Australian majority indicates that puerperal patients most likely had stronger family networks, which led to their illness being identified and their incarceration in the asylum.

Table 1.6: Nationalities of Puerperal Patients in Fremantle Lunatic Asylum (1858-1908)

\begin{tabular}{|l|r|r|r|r|r|r|r|r|r|}
\hline & Vic & Colonial & English & WA & Irish & SA & British & Scottish & N/A \\
\hline Total & 16 & 7 & 5 & 2 & 2 & 2 & 2 & 2 & 21 \\
\hline$\%$ & $26 \%$ & $11.3 \%$ & $8 \%$ & $3.2 \%$ & $3.2 \%$ & $3.2 \%$ & $3.2 \%$ & $3.2 \%$ & $34 \%$ \\
\hline
\end{tabular}

Source: Author's research.

Interestingly, of the 62 puerperal patients, 38 (61.3 per cent) were discharged from the asylum at some point, as seen in Table 1.7. Overall, most of the women admitted were later transferred to Claremont (35.5 per cent), were discharged just once (32.3 per cent), with another 13 per cent discharged multiple times, or died in the asylum (19.3 per cent). ${ }^{45}$ These statistics reveal that most puerperal patients were discharged from the asylum at one time or another. This clearly illustrates that nineteenthcentury physicians believed that puerperal insanity was curable and not a long-term issue. However, of all those discharged, 47.4 per cent were readmitted to the asylum, indicating that despite this attitude, their mental illnesses were often not effectually 'cured' or treated.

Table 1.7: Puerperal Patients Who Were Discharged, Died or Transferred in the Fremantle Lunatic Asylum (1858-1908)

\begin{tabular}{|l|r|r|r|r|}
\hline & \multicolumn{1}{|c|}{$\begin{array}{c}\text { Discharged } \\
\text { Once }\end{array}$} & \multicolumn{1}{c|}{$\begin{array}{l}\text { Discharged } \\
\text { Multiple }\end{array}$} & \multicolumn{1}{c|}{ Died } & Transferred \\
\hline Total & 20 & 8 & 12 & 22 \\
\hline$\%$ & $32.3 \%$ & $13 \%$ & $19.3 \%$ & $35.5 \%$ \\
\hline
\end{tabular}

Note: 38 women were discharged at some point, including the number indicated in the discharged sections of the table and 10 women from the section of those who were later transferred to Claremont $=61.3 \%$ of all puerperal patients.

Source: Author's research.

44 Australian nationality in the patient notes did not include Indigenous women admitted, of which there were five with one woman labelled 'half-caste'.

45 Of those transferred to Claremont, three patients were admitted before 1900, and 19 were admitted from 1900; thus, there was less time for those patients to potentially recover before the move to the Claremont Hospital for the Insane in 1908. 
It is important to note that the patient registers and case books from the Fremantle Lunatic Asylum are potentially problematic resources. The medical superintendents did not always record information consistently, and not every patient has a complete entry. Another factor that should be considered is that they are not written from the perspective of the women; they were written by male medical professionals whose interpretations and diagnoses were influenced by their context. Further, most of the women admitted to Fremantle were illiterate. Literacy was rarely noted in the registers and case books. Dr Attfield made more effort in 1858 to 1872; however, 94 per cent of the women did not have this skill mentioned in their records. Only 10 women were noted to be able to write, eight to read, six for reading and writing, and three were listed as illiterate. Therefore, these patient notes are likely the few remaining sources that provide some understandings of their experiences. Through examining the male medical doctors' notes and assembling new data concerning female patients across the whole period the Fremantle Asylum was in operation, the women admitted for puerperal reasons take greater shape and allow deeper insights into an aspect of their lives. While not personal accounts, they reveal how nineteenth-century colonial physicians categorised and treated women suffering from a gendered form of madness, and thus are invaluable to understandings of the history of mental illness.

\section{Domestic Work and Gendered Madness}

An important feature of moral treatment was to refrain from treating patients inhumanely. A prominent advocate of humane moral treatment was English physician John Conolly who proposed that inmates be allowed the freedom to control their behaviour under the observation of the attendants. ${ }^{46}$ Therefore, nineteenth-century asylums also began to reduce the use of mechanical restraints. ${ }^{47}$ The implementation of this was inconsistent, though most British superintendents did not abolish all forms of restraint. ${ }^{48}$ The irregularity in non-restraint methods in moral

46 Susan Piddock, "The "Ideal Asylum" and Nineteenth-Century Lunatic Asylums in South Australia', in Madness in Australia: Histories, Heritage and the Asylum, eds. Catherine Coleborne and Dolly MacKinnon (Brisbane: University of Queensland Press, 2003), 38.

47 Nancy Tomes, 'The Great Restraint Controversy: A Comparative Perspective on Anglo-American Psychiatry in the Nineteenth Century', in The Anatomy of Madness: Essays in the History of Psychiatry, Vol III: The Asylum and its Psychiatry, eds. William F Bynum, Roy Porter and Michael Shepherd (London: Routledge, 2004), 190, doi.org/10.4324/9781315017112-8.

48 Tomes, 'Great Restraint Controversy', 196. 
treatment was evident in the Australian colonies where the use of restraints persisted, due in part to the colonies' penal origins and their focus on punishment. ${ }^{49}$ Thus, Stephen Garton comments that immediate reform was inhibited by these foundations as well as a general lack of funding. ${ }^{50}$ However, as Peta Longhurst writes, reform in treatment was reflected in improvements in the construction of asylums, and the presence of updated government asylums in New South Wales from at least 1838 reveals an incentive to provide more humane treatment in the Australian colonies. ${ }^{51}$

Work was an essential aspect of moral treatment, it kept patients occupied, which minimised the potential need for the use of restraint. Patient work in psychiatry required routine and acceptance of discipline, which was crucial to re-entering nineteenth-century society. ${ }^{52}$ Therapeutic labour was first introduced into asylums in the 1830s at Conolly's Hanwell Asylum. ${ }^{53}$ Work as rehabilitation was deemed necessary for the 'curable' and convalescent, and was also gradually introduced to the 'chronic' or intellectually disabled patients. ${ }^{54}$ Anne Digby writes that women were the best-occupied patients in the nineteenth century, as it was comparatively easier to employ women in household tasks. ${ }^{55}$ Male patients were taught trades if possible, but they were rarely employed beyond physical labouring in the asylum grounds. ${ }^{56}$ Domestic tasks were deemed unsuitable for men and would not contribute to their recovery. ${ }^{57}$ Conversely, the association between women and domesticity ensured constant employment in the asylum laundry, sewing, knitting, and in self-cleanliness. ${ }^{58}$ As a result, for the female patients domestic tasks were effectively retraining women in expected gender roles.

49 Kenneth C Kirkby, 'History of Psychiatry in Australia, pre-1960', History of Psychiatry, 10, no. 38 (1999): 193, 199, doi.org/10.1177/0957154x9901003802.

50 Stephen Garton, 'Why Asylum Facilities Might Still Be Relevant for Mental Health Care Services Today', Health and History, 11, no. 1 (2009): 33.

51 Peta Longhurst, 'Madness and the Material Environment: An Archaeology of Reform in and of the Asylum', International Journal of Historical Archaeology, 21 (2017): 33, doi.org/10.1007/ s10761-017-0399-0.

52 Waltraud Ernst, 'The Role of Work in Psychiatry: Historical reflections', Indian Journal of Psychiatry, 60, no. 2 (2018): online.

53 Showalter, Female Malady, 40.

54 Anne Digby, 'Moral Treatment at the Retreat, 1796-1846', in The Anatomy of Madness: Essays in the History of Psychiatry, Vol II: Institutions and Society, eds. William F Bynum, Roy Porter and Michael Shepherd (London: Routledge, 2004), 63, doi.org/10.4324/9781315017105-4.

55 Digby, 'Moral Treatment', 63.

56 Lee-Ann Monk, Attending Madness: At Work in the Australian Colonial Asylum (New York: Editions Rodopi BV, 2008), 71.

57 Monk, Attending Madness, 71.

58 Showalter, Female Malady, 79. 
Through these domestic tasks, nineteenth-century physicians reinforced stereotypes of femininity for women who they diagnosed as mentally ill and potentially defying contemporary gender roles. ${ }^{59}$ As Judith Butler states, gender is culturally constructed, and as such women's acceptable behaviour was also created by nineteenth-century society. Butler states that people are only recognised through gender intelligibility; therefore, identity is established through sex and gender, and a person is called into question if they do not act according to that gender. ${ }^{60}$ Anne Summers writes that 'femininity is a cultural imposition upon the female sex, an artificial contrivance designed to replace natural conduct and appearance with conventions which make their governing easier' ${ }^{61}$ Thus, nineteenthcentury Australian society, influenced by British colonialism, had specific expectations of women as wives and mothers. Characteristics for "good" women included quietness, modesty and cautiousness. ${ }^{62}$ Women should preserve the moral values of society, guard her husband's conscience and guide her children. ${ }^{63}$ Penny Russell writes that Australian women's place in respectable society was through her attachment to the home and family. ${ }^{64}$

This construction of gender was also apparent in defining mentally ill behaviours for women and men. Therefore, nineteenth-century Western societies perceived differences in how madness manifested in women and men. During this period, women's insanity could come under the umbrella term 'hysteria', which encompassed varying types of female madness, including religious ecstasy or sexual deviation. ${ }^{65}$ British physicians maintained that a woman's place in society, her role and behaviour were controlled by her reproductive organs. ${ }^{66}$ In 1878 , Bucknill and Tuke wrote that the reproductive organs are frequently

59 Ibid., 86.

60 Judith Butler, Gender Trouble: Feminism and the Subversion of Identity (New York: Routledge, 1990), 10-23.

61 Anne Summers, Damned Whores and God's Police: The Colonisation of Women in Australia (Sydney: NewSouth Publishing, 2016), 367.

62 Andrea Nicki, 'The Abused Mind: Feminist Theory, Psychiatric Disability, and Trauma', Hypatia, 16, no. 4 (2001): 90, doi.org/10.1353/hyp.2001.0060.

63 Sally Mitchell, Daily Life in Victorian England, 2nd ed. (Connecticut: Greenwood Press, 2009), 266.

64 Penny Russell, 'In Search of Woman's Place: An Historical Survey of Gender and Space in Nineteenth-Century Australia', Australasian Historical Archaeology, 11 (1993): 28.

65 Roy Porter, 'The Body and the Mind, the Doctor and the Patient: Negotiating Hysteria', in Hysteria Beyond Freud, ed. Sander L Gilman (Berkley: University of California Press, 1993), 227.

66 Andrew Scull, Hysteria: The Disturbing History (Oxford: Oxford University Press, 2009), 72. 
the seat of disease or abnormal function' ${ }^{67}$ As men's bodies have been the standard by which everything was compared, medical professionals viewed women's bodies, especially pregnant bodies, as dubious or potentially madness-inducing. ${ }^{68}$ Nineteenth-century medical authorities did not solely base their opinions on scientific fact but bent reality to the cultural perceptions and needs of their universe. ${ }^{69}$ Thus, there was a well-established connection between women's bodies and insanity in the nineteenth-century medical community.

The most apparent connection between women's bodies and madness was in puerperal insanity. While puerperal insanity was a unique nineteenthcentury diagnosis, women still suffer from postnatal depression, and there are continued scientific debates of the causes of postnatal mental illness. Modern medical professionals note there are many factors involved in postnatal depression, including hormonal changes, economic and relationship stress, previous traumas and a genetic predisposition to depression. However, nineteenth-century physicians deemed that the 'unusual excitement throughout the nervous system' and their weakened constitution due to pregnancy and childbirth predisposed women to madness. ${ }^{70}$ The combination of 'intestinal irritation, loss of blood and exhaustion' was what contributed to puerperal insanity. ${ }^{71}$ However, Marland argues that in the nineteenth century many women admitted to asylums with puerperal insanity were also unhealthy and suffering other diseases, which could also contribute to their mental state. Thus, it is essential to remember that there were likely women who suffered from some form of postnatal mental illness that did not seek or get help or were not diagnosed with puerperal insanity.

However, the biggest concern for nineteenth-century physicians was that puerperal patients acted outside the bounds of womanhood. Puerperal patients 'challenged notions of domesticity and femininity and flouted ideals of maternal conduct and feeling'..$^{72}$ Nancy Theriot contends that

67 John Charles Bucknill and Daniel Hack Tuke, A Manual of Psychological Medicine Containing the Lunacy Laws, the Nosology, Aetiology, Statistics, Description, Diagnosis, Pathology and Treatment of Insanity, 3rd ed. (Philadelphia: Lindsay and Blakiston, 1874), 595, doi.org/10.1192/ s0368315x00227059.

68 Rebecca Kukla, Mass Hysteria: Medicine, Culture, and Mother's Bodies (Maryland: Rowman \& Littlefield Publishers Inc., 2005), 3.

69 Robert Muchembled, Orgasm and the West: A History of Pleasure from the Sixteenth Century to the Present, trans. J Birrell (Cambridge: Polity Press, 2008), 160.

70 Marland, Dangerous Motherhood, 41.

71 Ibid.

72 Ibid., 5. 
women's indifference or hostility to children or husbands contradicted physicians' notions about women's 'maternal and wifely devotion'. ${ }^{73}$ Therefore, as Theriot argues, puerperal insanity was a socially constructed disease, reflecting both nineteenth-century gender constraints and the professional battles accompanying medical specialisation. ${ }^{74}$ She asserts that whether on a conscious or unconscious level, women who suffered from puerperal insanity were rebelling against the constraints of gender. ${ }^{75}$ Hilary Marland also notes that physicians believed that social, economic and circumstantial situations like poverty, domestic difficulties and 'the despair of motherhood' were causes of puerperal insanity. ${ }^{76}$ Thus, there was an awareness of a connection between the constraints of women's lives and mental illness. As Bronwyn Labrum notes, 'the existence of feminine notions of respectability affirms the importance of gender in studies of madness. ${ }^{77}$ However, female patients in colonial contexts were not labelled as insane only due to their lack of feminine behaviours, and there is no evidence of a fundamental link between women and madness. ${ }^{78}$ Labrum argues that the realities of women's lives and the conditions they lived with their families were equally important factors. ${ }^{79}$ Nevertheless, an analysis of puerperal insanity patients illustrate how nineteenth- and early twentieth-century moral treatment aimed to reinforce gender roles, as these women behaved in opposition to the ideal wife and mother.

\section{'Discharged Recovered': Charlotte and Edith}

In the Fremantle Lunatic Asylum, work was encouraged for all women, including the puerperal patients. However, a reluctance to perform household tasks was punishable, incurring lengthier stays. ${ }^{80}$ As Catharine

73 Nancy Theriot, 'Diagnosing Unnatural Motherhood: Nineteenth-century Physicians and "Puerperal Insanity”, American Studies, 30, no. 2 (1989): 74.

74 Theriot, 'Diagnosing Unnatural Motherhood', 72.

75 Ibid., 81.

76 Hilary Marland, 'Women, Health, and Medicine', in The Oxford Handbook of the History of Medicine, ed. Mark Jackson (Oxford: Oxford University Press, 2011), 491.

77 Bronwyn Labrum, 'Looking Beyond the Asylum: Gender and the Process of Committal in Auckland, 1870-1910', New Zealand Journal of History, 26, no. 2. (1992): 144.

78 Ibid.

79 Ibid.

80 Bronwyn Harman, 'Out of Mind, Out of Sight: Women Incarcerated as Insane in Western Australia 1858-1908' (PhD thesis, University of Western Australia, 1993), 117. 
Coleborne writes, a female patient's refusal to work would be read as a rejection of attempts to 'reform' and 'tame' her. ${ }^{81}$ This attitude was reflected in Fremantle as physicians emphasised a willingness to work, rather than the amount of work completed. ${ }^{82}$ It was the activity itself that was thought to be therapeutic rather than the end product. ${ }^{83}$

In Fremantle, women diagnosed with puerperal insanity would often be 'cured' and sent home after a short amount of time. This theory was based on the belief that puerperal insanity was temporary, though severe, and likely to be curable. ${ }^{84}$ In 1846 , Conolly stated that 'cases of puerperal insanity appear to afford a better prospect of recovery than any other'. ${ }^{85}$ Allan Campbell notes that 'curing the patient meant restoring her to a condition fit for return to home, family and the responsibilities of her role as wife and mother'. ${ }^{86}$ In 1903, Australian asylum superintendent William Beattie Smith stated that 'half the cases recover in four months, and thence onward to the ninth month, with a few recoveries even as late as a couple of years' ${ }^{87}$ This attitude was displayed in Fremantle; patients with puerperal insanity who were willing to undertake domestic tasks would often have short asylum admissions. Table 1.7 shows that 61 per cent of all puerperal patients were discharged. This theory was in operation in Fremantle, as will be explored through the patient notes of Charlotte and Edith. However, a speedy turnaround of puerperal patients into their husband's care did not necessarily result in the patients' 'cure' or indicate that they had received the help they needed.

Charlotte Isabella Lyford was 26 years old when she was admitted on 11 January 1904 with puerperal melancholia caused by childbirth. ${ }^{88}$ She was 'melancholic in demeanour' and had made 'unfounded charges

81 Catharine Coleborne, 'Space, Power and Gender in the Asylum in Victoria, 1850s-1870s', in Madness in Australia: Histories, Heritage, and the Asylum, eds. Catharine Coleborne and Dolly MacKinnon (Brisbane: University of Queensland Press, 2003), 55.

82 Harman, 'Out of Mind, Out of Sight', 117-18.

83 Digby, 'Moral Treatment', 63.

84 Hilary Marland, "'Destined to a Perfect Recovery”: The Confinement of Puerperal Insanity in the Nineteenth Century', in Insanity, Institution and Society, 1800-1914, eds. Bill Forsythe and Joseph Melling (Oxon: Routledge, 1999), 137.

85 John Conolly, 'Description and Treatment of Puerperal Insanity', Lecture XIII: Clinical Lectures on the Principle Forms of Insanity, Delivered in the Middlesex Lunatic Asylum at Hanwell, Lancet 1, 28 March 1846, 349, doi.org/10.1016/s0140-6736(02)89248-0.

86 Allan Campbell, "'Noisy, restless and incoherent"', 54.

87 William Beattie Smith, 'Insanity in its Relations to the Practioner, the Patient, and the State', Intercolonial Medical Journal of Australia, 8, no. 2 (1903): 67.

88 SROWA: Case Book Female Patients, 1901-08, Folio 151, 11 January 1904. 
of unfaithfulness against her husband', William. ${ }^{89}$ Dr Montgomery noted Charlotte was 'very dull and stupid, will not speak when spoken to' and had 'to be forced to eat, will not dress or undress herself'. ${ }^{90}$ However, in March, Charlotte began to improve, she was more cheerful, and her delusions were disappearing. ${ }^{91}$ Her improvement continued in April when she 'started to work', and from then she was considered convalescent. ${ }^{92}$ On 2 May Charlotte was given a month's trial release; however, she was 'discharged recovered' merely two days later, after four months in the asylum..$^{93}$ Thus, Charlotte's improved condition was noted through her cheerful demeanour, less obvious delusions and, importantly, her willingness to work.

Edith Maude Jones was also admitted for a short time. Edith was 19 years old when she was admitted on 5 October 1904 with 'puerperal mania' caused by 'puerperium'. ${ }^{94}$ Edith was noted to be dangerous to her three-week-old child, William Ronald, and her medical certificate stated: 'very incoherent, delusions of persecution, aversion to her child, often to husband', James. ${ }^{95}$ Dr William Blackall noted her mental condition as 'emotional'. ${ }^{96}$ However, by the end of October, Edith was 'very much improved, quite coherent, useful in infirmary, quiet', although she 'still had tendency to emotional laughter' ${ }^{97}$ In November, Blackall reported that Edith's improvement was maintained, 'but the abnormal cheerfulness and lack of desire of discharge persists. ${ }^{98}$ Edith relapsed in early November but by the end of the month she was 'improving again, much more rational, quiet and tidy'. ${ }^{99}$ In December, Blackall wrote again that she 'does not seem anxious to see her infant nor for her discharge'. ${ }^{100}$ However, in January 1905 it was reported that Edith 'remains well, useful but perhaps too cheerful'. ${ }^{101}$ Edith was 'discharged

89 Ibid.

90 Ibid.

91 Ibid., Folio 151-152, 14-28 March 1904.

92 Ibid., 14-28 April 1904.

93 Ibid., 2-4 May 1904.

94 Ibid., Folio 199, 5-9 October 1904.

95 Ibid.; BDMWA: Certificate of Birth, William Ronald (778/1904).

96 SROWA: Case Book Female Patients, 1901-08, Folio 199, 5-9 October 1904. Blackall was medical officer to Dr Montgomery from 1904-08.

97 Ibid., 27 October 1904.

98 Ibid., 3 November 1904.

99 Folio 199, 5-9 October 1904, 8-25 November 1904.

100 Ibid., 8 December 1904.

101 Ibid., 5 January 1905. 
recovered' on 12 January after three months in the asylum. ${ }^{102}$ The asylum staff considered Edith's work in the asylum infirmary, likely to be cleaning or laundry, to be a vast improvement, although they noted her disinterest in her child was concerning.

Both Charlotte and Edith were discharged after short asylum admissions. They were considered well enough for discharge when they began to show signs of improvement through the moral treatment methods of domestic chores as rehabilitation. Marland writes that many women may have seen the diagnosis of puerperal insanity and the treatment as a possible respite from the household and maternal duties. ${ }^{103}$ While it may have been a break from the children, especially in Edith's case, the treatment emphasised domestic duties to ready them for the home. Other factors may have led to Charlotte's and Edith's discharges, possibly even time. O'Hara and McCabe reported in 2013 that 'postpartum blues' are a common and transient mood disturbance that can often occur three to five days after childbirth, but the postpartum depression (PPD) period varies from four weeks to a year. ${ }^{104}$ However long the period may have lasted, moral treatment aimed to instil 'good' behaviours in women by ensuring they left the asylum able to fulfil their role as a wife and mother. As will be explored in the following cases of Catherine and Flora, however, the short asylum admissions and moral treatment methods did not necessarily result in a cure.

\section{'Puerperal Mania': Catherine Blackmore}

One of the first women Fremantle physicians diagnosed and recorded as suffering with puerperal mania was Catherine Blackmore. Catherine was a 29-year-old Catholic wife of a York farm labourer, Patrick, when she was admitted with 'puerperal mania' on 26 January $1863 .{ }^{105}$ Catherine had been sent from Perth on the certificate of Drs Ferguson and Poulton after spending three months under treatment in the Perth Hospital and the Perth Poor House. ${ }^{106}$ The admission entry revealed that 'some

102 Ibid., 12 January 1905.

103 Marland, Dangerous Motherhood, 142.

104 Michael W O'Hara and Jennifer E McCabe, 'Postpartum Depression: Current Status and Future Directions', Annual Review of Clinical Psychology, 9 (2013): 381-2.

105 SROWA: Register of Female Patients, 1858-73, Folio 60, 26 January 1863. Catherine's name was also recorded as Caroline and Mary. York is a small wheatbelt town, 97 kilometres from Perth. 106 Ibid. 
symptoms of deranged intellect showed themselves soon after her last confinement (about four months ago) the peculiar symptoms however are not known'. ${ }^{107}$ The Births, Deaths, and Marriages Index of Western Australian reveals that in 1862, Catherine gave birth to her fourth child, Samuel; she had also lost her second baby, James, in 1859, at 10 months old. ${ }^{108}$ Catherine's mental state may have been impacted by having another baby after her son's death. While in the asylum, and not noted in her records, Samuel died at six months old in March, two months after her admission. ${ }^{109}$ Catherine's patient notes, written by Dr Attfield, stated that she was 'of sullen disposition and sometimes violent', and that she had 'rather a wild haggard unsettling look'. ${ }^{110}$ Although she seemed to comprehend questions, she would not answer the physicians. ${ }^{111}$

Catherine was not reported on again for three months, when in April Attfield noted anomalies in her menstruation. Eighteenth- and nineteenth-century doctors regarded puberty as the most psychologically dangerous period of the female life cycle, believing that menstrual discharge predisposed women to insanity. ${ }^{112}$ In Catherine's patient notes Attfield wrote, 'very little alteration has taken place', she had 'menstruated twice since admission but very scantily. ${ }^{113} \mathrm{He}$ also reported that she was 'sometimes very willing to do any work in washing and cleaning, always dresses herself'. ${ }^{114}$ By June, Catherine was recorded as having 'a less downcast look and is more prompt and ready when spoken to' but would still not answer questions and menstruated irregularly. ${ }^{115}$ In August, Attfield wrote that she 'does any kind of work in cleaning, washing and scrubbing to which she is put'; however, she was 'as taciturn and moody as when she first came', and her catamenia was now absent. ${ }^{116}$ Thus, the concern over Catherine's menstrual cycle was evident in the patient records, and it continued to be tracked and noted into 1864 .

107 Ibid.

108 Ibid. Catherine had five children across 1856-68; BDMWA: Certificate of Birth: Mary Jane (3470/1856), James (4213/1858 - d. 1208/1859), Thomas (5053/1860), Samuel (6575/1862 d. 2142/1863), Katherine Elizabeth (10549/1868).

109 SROWA: Register of Female Patients, 1858-73, Folio 60, 26 January 1863.

110 Ibid.

111 Ibid.

112 Showalter, Female Malady, 56.

113 SROWA: Register of Female Patients, 1858-73, Folio 60, 27 April 1863.

114 Ibid.

115 Ibid., 16 June 1863.

116 Ibid., Folio 62, 19 August 1863. 
Despite the physicians' concerns over menstruation, Catherine's willingness to work was positively reported. By April 1864, Attfield commented that Catherine was 'always willing to any work that is set her'. ${ }^{117}$ In July, Catherine's husband and child visited her in the asylum, it had been over a year since she had seen them. ${ }^{118}$ She was reported to have recognised them 'but would not speak a word to them. She does not however fret.' ${ }^{119}$ In September, Attfield noted that 'catamenia now regular, looks wonderfully improved in health, but can hardly be induced to speak'. ${ }^{20}$ This behaviour was maintained and, in October 1865, Patrick applied 'to the Governor to be allowed to take his wife home'; Catherine was noted as 'improved but not sane'. ${ }^{121}$ Attfield wrote that 'her husband having promised to keep supervision over her and treat her kindly was allowed to take her home'. ${ }^{122}$ Therefore, the combination of improved menstruation and willingness to work was acknowledged as an improvement, although not a complete cure.

However, Catherine's 'improved' mental state did not last. On 24 October 1895, 30 years after her discharge, Catherine was readmitted, a 70-yearold 'semi-imbecile' reported as 'harmless and silent'. ${ }^{123}$ At the same time, Catherine's daughter Elizabeth Blackmore was also sent from Katanning by the same physician, Dr Adam. ${ }^{124}$ Elizabeth was a 27-yearold with 'dementia'; Dr Barnett noted 'these hereditary cases are usually hopeless'. ${ }^{125}$ Heredity was especially considered in cases of puerperal insanity: if the family was insane, it was considered a 'predisposition' to mental unbalance. ${ }^{126}$ Catherine spent the rest of her life in the asylum and died on 18 January 1899 aged $74 .^{127}$

Catherine's case reveals the moral treatment methods in Fremantle and also the impact that mental illness could have intergenerationally. Catherine's treatment in the asylum was based on the moral treatment

117 Ibid., Folio 62, 15 April 1864.

118 Ibid., 19 July 1864.

119 Ibid.

120 Ibid., 12 September 1864.

121 Ibid., Folio 83, 2 October 1865.

122 Ibid.

123 SROWA: Case Book Female Patients, 1878-97, Folio 182, 24 October 1895.

124 SROWA: Case Book Female Patients, 1878-97, Folio 182, 24 October 1895.

125 Ibid., Folio 183, 8 November 1895. Elizabeth was discharged to her sister Mary Jane Bradbury in March 1896. She was readmitted in August with 'suicidal insanity', and discharged in January 1897.

126 Theriot, 'Diagnosing Unnatural Motherhood', 77.

127 SROWA: Female Occurrence and Daily Strength Book, 1895-1901, Folio 436, 18 January 1899. 
methods of domestic chores. Her ability and willingness to complete the tasks garnered positive reports, though her irregular menstrual cycle was believed to worsen her condition. Catherine's case reveals that although the asylum staff were aware that she was not completely 'sane', husbands would be granted their wives' discharge if their improvement through domestic tasks was deemed good enough for release. Thus, nineteenthcentury physicians determined that sane behaviour for women was competency in domestic work and the ability to care for their family.

\section{'Puerperal State': Florence 'Flora' Mary Brown}

On 27 September 1903, Florence 'Flora' Mary Brown, a 30-year-old Presbyterian housewife from Kalgoorlie, was admitted to the asylum by her husband Adam in a 'puerperal state' after the birth of her daughter, Mary Florence. ${ }^{128}$ Flora was diagnosed with puerperal mania and described as 'thin and emaciated, brown hair, blue eyes' with a wild manner, 'excited and restless, refuses food, is destructive and at times violent. Scratches and bites. ${ }^{129}$ In October, Dr Montgomery reported Flora to be 'very dull and stupid' and 'will not employ herself'; by November she was still noted as 'continually lazy'. ${ }^{130}$ However, by June 1904 Flora was 'much better, is sewing and seems to take more interest in things'. ${ }^{131}$ In September, Dr Blackall reported that Flora 'varies a great deal between fairly normal mental stability and distinct insanity, she has lately maintained her improved condition for a longer time than normal'. ${ }^{132}$ Consequently, on 23 September, Flora was 'discharged relieved to care of husband'. ${ }^{133}$ Despite Flora's fluctuating mental state, Blackall believed she was well enough to undertake domestic chores at home, which would enable her to care for her family.

128 SROWA: Case Book Female Patients, 1901-08, Folio 121, 27 September 1903; BDMWA: Certificate of Birth, Mary Florence (1701/1903). Kalgoorlie is a Goldfields town 595 kilometres north-east of Perth.

129 SROWA: Case Book Female Patients, 1901-08, Folio 121, 27 September 1903.

130 SROWA: Case Book Female Patients, 1901-08, Folio 121, 7-14 October; SROWA: Case Book Female Patients, 1901-08, Folio 121, 28 November 1903.

131 Ibid., Folio 122, 3 June 1904.

132 Ibid., 5 September 1904.

133 Ibid., 23 September 1904. 
However, the following year on 27 September 1905, Flora was readmitted with melancholia of lactation due to childbirth: her second child, John Donald, was born two months previously. ${ }^{134}$ In her physical exam, Dr Blackall noted that Flora looked 'ill and worn out', and that she 'has a child 2 months old, both breasts hard and full of milk. Abdomen flaccid and such as would be expected after recent confinement'. ${ }^{135}$ Lactational insanity, also taking manic or melancholic form, was seen by nineteenth-century physicians to exhaust the system and lead to depression. ${ }^{136}$ Physicians also believed it to be curable; removal of the patient from her home and its 'associated distress' would solve her problems. ${ }^{137}$ Lactational insanity was reported to only occur in women with several children, not first-time pregnancies, and indeed this was Flora's second pregnancy. ${ }^{138}$

Flora was also in a similar condition to her arrival just before her discharge. Blackall recorded that she was 'quiet and inclined to be resistive, melancholic appearance, speaks very little' and was suicidal. ${ }^{139}$ Sixteen days later, Blackall reaffirmed that 'she has returned to very much the same condition she was in for months previous to her last discharge, quiet and silent, abstracted, rather resistive, smiles vacantly, can answer coherently'. ${ }^{140}$ On 27 October, Flora 'secreted a knife in her dress "to cut her head off" and was placed on a red ticket, a form of suicide watch. ${ }^{141}$ In November, Blackall reported that there was 'little or no change, chattering to herself all day long "why can't I get out of this place; why was I brought here amongst all these people"'. ${ }^{142}$ By 1908 , Flora had made 'no improvement, full of delusions' and she was transferred to Claremont in June. ${ }^{143}$ Flora's battle with suicidal thoughts was deemed too risky for discharge.

134 Ibid., Folio 289, 27 September 1905; BDMWA: Certificate of Birth, John Donald (1857/1905).

135 SROWA: Case Book Female Patients, 1901-08, Folio 289, 27 September 1905.

136 Marland, Dangerous Motherhood, 26.

137 Ibid.

138 Theriot, 'Diagnosing Unnatural Motherhood', 73.

139 SROWA: Case Book Female Patients, 1901-08, Folio 289, 27 September 1905.

140 Ibid., 12 October 1905.

141 Ibid., 27 October 1905.

142 Ibid., 16 November 1905.

143 Ibid., 24 January; 5 June 1908. Flora's story continues in the Claremont records but they are out of the scope of this project. Further research would provide insights into puerperal admissions in the twentieth century. 
Flora's removal to the asylum after the birth of her first baby lasted 10 months, ending when she began to function well enough to care for her family and household. However, her readmission suggests that her potential psychological issues were not cured or understood as she also suffered at the birth of her next baby. The similar mental state was mentioned in her patient notes, although with varying reasons for admission, they were still connected to childbirth and lactation. Therefore, Flora's inability to handle domestic life after childbirth directly impacted her asylum admission. Flora's case also reveals that despite becoming successful at domestic tasks through moral treatment, the method did not cure all the patients. Flora's readmission suggests she, and possibly others, were susceptible to the same recurrent issues that were seemingly left untreated.

\section{Conclusion}

In nineteenth-century society and in the medical community, puerperal insanity was believed to be the ultimate in female mental weakness, an inability to handle the one job they were supposed to do as women. To treat puerperal insanity, the physicians at the Fremantle Lunatic Asylum, from 1858 to 1908, aimed to incorporate the British innovation of moral treatment and introduced work as rehabilitation. This method utilised and represented the ideal of womanhood: cleaning, caring, quietness.

However, the performance of domestic tasks could lead to recovery without treating potentially deeper psychological issues or providing the women with the help they needed. Thus, nineteenth- and early twentiethcentury physicians were yet to understand the complexities of women's postpartum responses. The willingness or ability to complete domestic tasks did not always translate into a healthy mental state, with women who suffered from puerperal insanity often readmitted to the asylum after they had been discharged.

Using original data assembled from the patient registers and case books of the Fremantle Lunatic Asylum, this paper provides insights into colonial women's experiences with diagnosis and treatment methods. In particular, the analysis of women's experiences with asylum care for puerperal insanity placed the women of Fremantle within the existing historical 
scholarship on gendered asylum experiences. This study reveals the value that nineteenth- and early twentieth-century physicians in Fremantle placed on moral treatment and the importance of female gender roles.

Today, societal myths of motherhood still result in women hiding their postnatal depression symptoms. ${ }^{144}$ Alternatively, if and when women do seek help, others may dismiss their concerns. ${ }^{145}$ However, an Australian study from 2019 reveals that awareness of postnatal depression has improved; although, there is still a lack of understanding regarding mental health during pregnancy and awareness of this impact on fathers. ${ }^{146}$ Therefore, continued research in all academic disciplines contributes to removing stigma and constructing a dialogue on postnatal depression. By understanding how women diagnosed with puerperal insanity were treated in nineteenth- and early twentieth-century asylums, this paper provides greater insights into colonial Fremantle women's lives and provides further context for understanding postnatal responses in women today.

144 Teresa M Twomey and Shoshana Bennett, Understanding Postpartum Psychosis: A Temporary Madness (Westport: Praeger Publishers, 2009), xvi.

145 Ibid., xvi.

146 Terri Smith, Alan W Gemmill and Jeannette Milgrom, 'Perinatal Anxiety and Depression: Awareness and Attitudes in Australia', International Journal of Social Psychiatry, 65, no. 5 (2019): 385, doi.org/10.1177/0020764019852656. 



\title{
'I Don’t Want Anything Like That': The Coercion of British Women and Girls into Domestic Service, 1918-1928
}

\author{
Elmarí Whyte
}

University of Queensland

\begin{abstract}
Despite the First World War (WWI) challenging women's traditional sphere of work (the home) as well as Britain's class structure, domestic service remained the largest employer of women and girls until the end of the Second World War. Why, given the reluctance of working-class women to return to domestic service after WWI, did so many take up 'hated domestic service' in the decade following the war? ${ }^{1}$ WWI increased working-class households' reliance on women's income-whether obtained through employment or unemployment benefits. While others have shown the role of state coercion in women's employment in domestic service in the aftermath of WWI, this article highlights the extent to which working-class families were complicit in that coercion. As many British families were deprived of male breadwinners as a result of the war, some pushed their daughters to work as servants as it was one job 'that any girl could get'. Others turned to the occupation as a means of protecting the 'moral health' of a daughter, where they considered it to be in danger. ${ }^{3}$ Drawing upon a range of oral history testimonies, this article examines the role of working-class families in ensuring that domestic service remained an important feature of working-class women's and girls' lives throughout the 1920s.
\end{abstract}

\footnotetext{
1 Deirdre Beddoe, Back to Home and Duty: Women between the Wars, 1918-1939 (London: Pandora Press, 1989), 49.

2 Mr Hudson quoted in: Domestic Service Interview with Mrs Irene Hudson, 26 February 1975, GB131.1103, Manchester Studies 25, Tameside Local Studies and Archive Centre (hereafter TLSAC), Ashton-under-Lyne.

3 Selina Todd, 'Poverty and Aspiration: Young Women's Entry to Employment in Inter-War England', Twentieth Century British History, 15, no. 2 (2004): 138, doi.org/10.1093/tcbh/15.2.119.
} 
My mother ... used to threaten me that she would put me in service but I never took the threat seriously, but the day I was fourteen arrived ... and she said now you are going to Mrs Wright's tomorrow morning.

- Mrs Sandys, Manchester-based domestic servant, 1920s-1930s ${ }^{4}$

My mother ... put an advertisement in the news. She got a hundred and twenty replies for a job for me, and it ended up with me going in service.

- Irene Hudson, Manchester-based domestic servant, $1920 s^{5}$

Approximately 400,000 British women were reported to have left domestic service for work in munitions factories and other war-related industries during the First World War (WWI). ${ }^{6}$ They joined another 4.4 million women engaged in the 'industrial labour force' by April 1918. 'While domestic service in Britain had commenced its decline as an employer of women by the end of the nineteenth century, 'Personal Service'-as recorded in the Census of England and Wales-decreased at double the rate between 1911 and 1921 than it had between 1910 and $1911 .^{8}$ WWI clearly had a significant impact on domestic service as an occupation in Britain.

Before 1914, domestic service was an assumed means of earning an income for many working-class girls, from the time they left school until they married.' However, the war had shaken Britain's Victorian and Edwardian class structure, though not completely upending it. Master and servant, fighting and dying side-by-side at the Somme and at Passchendaele, challenged what formerly seemed an unbridgeable class gap. Working-class widows and daughters sacrificed their husbands and fathers by the hundreds of thousands, all the while keeping the home fires burning. In post-1918 Britain, they would not unquestioningly slip

4 Domestic Service Interview with Mrs Sandys, 28 January 1975, GB131.1103, Manchester Studies 29, TLSAC, Ashton-under-Lyne.

5 Interview with Mrs Hudson.

6 Gail Braybon and Penny Summerfield, Out of the Cage: Women's Experiences in Two World Wars (London \& New York: Routledge \& Kegan Paul Ltd, 1987), 39.

7 Gail Braybon, Women Workers in the First World War: The British Experience (London: Croom Helm, 1981), 47; Adam W. Kirkaldy, Industry and Finance (Supplementary Volume) (London: Sir Isaac Pitman \& Sons, Ltd, 1920), 1.

8 Edward James, 'Women at Work in Twentieth Century Britain', The Manchester School, 30, no. 3 (1962): 283-99. See also Theresa M McBride, The Domestic Revolution: The Modernisation of Household Service in England and France 1820-1920 (London: Croom Helm, 1976), 112.

9 Pamela Horn, Life Below Stairs in the 20th Century (Stroud: Sutton Publishing, 2001), 141. 
back into accepting the authority, assumed superiority and condescension servant-keepers were wont to visit on their employees. As one Manchester-based servant recalled of the period, domestic employers had to start treating their employees 'as human beings ... as equals' given that 'girls were beginning to have a better opinion of themselves'. ${ }^{10}$ As other job opportunities became available to women-in factories, shops and offices-domestic service became an occupation of last resort. ${ }^{11}$ It was this low status of the occupation, coupled with poor working conditions, that caused women to 'struggle so bitterly against "going into service". ${ }^{12}$ That struggle was not to be easily won.

Yet after decades of decline, domestic service in Britain showed its first slight increase in the 1931 census. ${ }^{13}$ While that rise was clearly a result of the Great Depression, it was not the sole contributing element. The Depression might have tipped the percentage of employed women in domestic service into 'increase' territory, but there were factors at play before October 1929 that actively worked against the downward trajectory the occupation had been experiencing. This article hones in on those factors in the decade immediately following WWI, to explain why working-class women's and girls' employment in domestic service did not decline more dramatically in the lead-up to the Depression.

Several scholars of interwar domestic service in Britain have reflected on the role of state coercion in compelling working-class women to return to domestic service or take up the occupation for the first time. A short survey of that work is provided in the next section, as well as a summary of those state coercion methods. In this article I argue, however, that working-class families sometimes colluded with the state in pushing girls and women into domestic service - an aspect that has mostly been overlooked in other scholarly writing. The remainder of the article contributes to rectifying that oversight in three sections. First, it explains why working-class families needed the women and girls in their households to be in paid employment after the war. Second, it explores why those women and girls were so reluctant for that work to be domestic service. Finally, this article turns to examine how working-class mothers, in particular, facilitated

10 Domestic Service Interview with Mrs Ethel Cleary, 16 September 1975, GB131.1103, Manchester Studies 28, TLSAC, Ashton-under-Lyne.

11 Pamela Horn, 'Experiment or Anachronism? The Role of the National Institute of Houseworkers', Labour History Review, 66, no. 1 (2001): 61, doi.org/10.3828/lhr.66.1.61.

12 Violet M Firth, The Psychology of the Servant Problem (London: CW Daniel Company, 1925), 14.

13 James, 'Women at Work', 291. 
and compelled their daughters' entry into domestic service. Through this, I will show that, while there were pressing economic needs that required female employment among the working class, parents' insistence that work be domestic, usually of the 'live-in' or residential kind, were sometimes driven by moral concerns. The vulnerability of those families, due to their inherent structural disadvantage, compounded the effects of the state's coercive policies.

To support my argument, I rely chiefly upon a collection of interviews held at the Tameside Local Studies and Archive Centre in Ashtonunder-Lyne, on the outskirts of Manchester. ${ }^{14}$ The interviews of approximately 40 former domestic servants formed part of a larger oral history project conducted by the Manchester Studies Unit in the 1970s. The unit was established in 1974 by Manchester Polytechnic-now Manchester Metropolitan University. It had a 'general commitment to the people's history' of Manchester and its region at a time when working-class areas of the city, especially, were being demolished for new developments at unprecedented rates. Among its efforts to rescue historical evidence of working-class life in the city, the unit conducted oral history interviews with distinct groups of working-class people. One such group was domestic servants; the records of those interviews are drawn upon in this article.

The domestic service interviews in the Manchester Studies Collection are particularly compelling due to the breadth and depth of information they have recorded. They provide an array of insights, not only into how domestic service was performed, but into the relationship between the domestic and public spheres during the early decades of the twentieth century. These insights pertain predominantly to the Greater Manchester area, where most of the women interviewed had lived and worked. Some grew up and/or worked outside North West England and added their experiences of life and domestic service elsewhere in the country.

Memory, as captured through oral history interviews, has been increasingly common as an historical source since the 1960s, but has not been uncontroversial-as Alistair Thomson's writing on the subject has shown. Oral history has been subject to criticism from conservative historians for

14 The Greater Manchester metropolitan county was created in 1974. In addition to the cities of Manchester and Salford, it includes the boroughs of Bolton, Bury, Oldham, Rochdale, Stockport, Tameside, Trafford and Wiggan. 
its unreliability as a source to those on the Left questioning whether it was 'necessarily radical and democratic'. ${ }^{15}$ In the 1980 s, challenges to the positivist ideas about the objectivity of the researcher emphasised the value of the oral history interview to both interviewer and narrator. ${ }^{16}$ When, as in the case with the Manchester Studies Collection, a person's memories are recorded 50 years or more after the events they are reflecting on, their recollections and the telling of their stories are, inevitably, influenced by their experiences in the intervening decades and by their ability to recall details with relative accuracy after such a long time.

It should also be noted that, due to time constraints, I consulted the transcripts of the interviews rather than the recordings themselves. Inflection, tone and other rich elements of 'the spoken word' get lost in the use of transcribed interviews, as Francis Good points out. ${ }^{17}$ Transcriptions are also subject to the 'selective editing' of transcribers and to the potential of blurring the lines between primary and secondary sources. ${ }^{18}$ These shortcomings notwithstanding, the transcribed interviews of these former domestic servants provide valuable insights into their individual circumstances in and around domestic service in the first half of the twentieth century.

\section{State Coercion and Domestic Service}

Academic interest in domestic service in Britain beyond the Edwardian era is still relatively new. Much of the focus of domestic service historians has been on the peak of the occupation-the Victorian era. ${ }^{19}$ Since 2000, studies concerned with domestic service beyond the beginning of WWI

15 Alistair Thomson, 'Memory and Remembering in Oral History', in The Oxford Handbook of Oral History, ed. Donald A Ritchie (Oxford: Oxford University Press, 2010), 80, doi.org/10.1093/ oxfordhb/9780195339550.013.0006.

16 Ibid.

17 Francis Good, 'Voice, Ear and Text: Words, Meaning and Transcription', in The Oral History Reader, eds. Robert Perks and Alistair Thomson (London \& New York: Routledge, 2016), 458.

18 Ibid., 459.

19 Pamela Horn, The Rise and Fall of the Victorian Servant (Wolfeboro, NH: A Sutton, 1990); Frank E Huggett, Life Below Stairs: Domestic Servants in England from Victorian Times (New York: Charles Scribner's Sons, 1977); Leonore Davidoff, 'Mastered for Life: Servant and Wife in Victorian and Edwardian England', Journal of Social History, 7, no. 4 (1974): 406-28, doi.org/10.1353/jsh/7.4.406; Edward Higgs, 'Domestic Servants and Households in Victorian England', Social History, 8, no. 2 (1983): 201-10, doi.org/10.1080/03071028308567561; Leonard Schwarz, 'English Servants and Their Employers During the Eighteenth and Nineteenth Centuries', Economic History Review, 52, no. 2 (1999): 236-56, doi.org/10.1111/1468-0289.00124. 
have increased, predominantly through work produced by Pamela Horn, Diane Aiken, Lucy Delap and Selina Todd. Horn and Aiken focus on the first half of the twentieth century, whereas Delap's work takes a more even view of the century in its entirety. ${ }^{20}$

Horn, Delap and especially Aiken highlight the role of the 'coercive nature of the unemployment benefits system' in working-class women's employment in domestic service between the wars. ${ }^{21}$ Domestic servants, while controversially included in the National Health Insurance (Part 1) aspect of the National Insurance Act 1911, were excluded from the much more restrictive Unemployment Insurance (Part 2) ${ }^{22}$ Under the Act, those employed in the male-dominated occupations of engineering, shipbuilding, and construction and building at the time were entitled to a maximum of 15 weeks' unemployment pay per year for involuntary unemployment. ${ }^{23}$ Unemployment insurance was expanded to occupations related to the war, including munitions workers, in $1916 .{ }^{24}$ This saw women eligible for unemployment insurance for the first time, and in huge numbers, which became problematic for authorities when WWI ended. If women took up domestic service, not only could they no longer collect unemployment benefits because they were employed, but they would cease to be eligible for those benefits if they became unemployed from their domestic service job. Employment in domestic service, therefore, removed unemployed women as a financial responsibility for the state.

Within a year of the Armistice, approximately 775,000 women had lost their wartime jobs. ${ }^{25}$ By March 1919, over half a million women were claiming unemployment benefits. In order to lift the burden of those benefit payments on government coffers, Lloyd George's government

20 Out of eight chapters of Pamela Horn's Life Below Stairs, five look at the period 1920 to 1939, one at 1900 to 1920, with two covering the remaining six decades: Horn, Life Below Stairs. See also: Diane Rose Aiken, 'The Central Committee on Women's Training and Employment: Tackling the Servant Problem, 1914-1945' (PhD thesis, Oxford Brookes University, 2002); Lucy Delap, Knowing Their Place: Domestic Service in Twentieth-Century Britain (Oxford; New York: Oxford University Press, 2011); Lucy Delap, 'Housework, Housewives and Domestic Workers: Twentieth Century Dilemmas of Domesticity', Home Cultures, 8, no. 2 (2011): 189-210, doi.org/10.2752/17517421 $1 \mathrm{x} 12961586699801$.

21 Delap, Knowing Their Place, 13.

22 Laura Schwartz, Feminism and the Servant Problem: Class and Domestic Labour in the Women's Suffrage Movement (Cambridge: Cambridge University Press, 2019), 173.

23 Pat Thane, 'The Making of National Insurance, 1911', The Journal of Poverty and Social Justice, 19, no. 3 (2011): 218.

24 Tony Lynes, 'From Unemployment Insurance to Assistance in Interwar Britain', Journal of Poverty and Social Justice, 19, no. 3 (2011): 221, doi.org/10.1332/175982711x596973.

25 Beddoe, Home and Duty, 48. 
introduced a suite of measures to reduce women's dependence on unemployment benefits while addressing middle-class women's demands for more and better servants. ${ }^{26} \mathrm{~A}$ primary vehicle for implementing the government's strategy to solve women's unemployment through domestic service was the Central Committee on Women's Training and Employment (CCWTE). The committee was established in August 1914, abandoned during WWI, and re-formed in 1919 under the Ministry of Labour. ${ }^{27}$ Over the course of the 1920s, the remit of the CCWTE narrowed from including training schemes for individuals and in various areas to focusing almost exclusively on group training for domestic service. Concentrating their efforts on domestic service training aided the governments of Stanley Baldwin (Conservative) and Ramsay MacDonald (Labour) in their defence of funding training for unemployed women in the face of male unemployment. ${ }^{28}$ The CCWTE received more than $£ 1,373,000$ to conduct their programs - the equivalent of roughly $£ 63$ million in 2017 - during the interwar period. ${ }^{29}$

The CCWTE was not the only weapon in the British government's arsenal to compel unemployed young women and girls into domestic service. Their work stood alongside that of Employment Exchanges and, later, Unemployment Assistance Boards. Employment Exchanges, with which people had to register to receive unemployment benefits, could match unemployed women with families in need of servants, but could also act with impunity where they refused to take up the positions offered. Employment Exchange officials exercised their power to withhold unemployment benefits to induce claimants to take up positions away from home. ${ }^{30}$ Such officials seemed oblivious to the very real obstacles women faced in the positions they were offered. For example, the requirement of many domestic service posts to 'live in' made it an unfeasible option for women with children (many of whom were war widows), which seemed baffling to officials. ${ }^{31}$

\footnotetext{
26 Ibid., 49; Aiken, 'Central Committee', 2.

27 Aiken, 'Central Committee', 2-3.

28 Ibid., 4.

29 Keith Laybourn, "Waking up to the Fact That There Are Any Unemployed": Women, Unemployment and the Domestic Solution in Britain, 1918-1939', History, 88, no. 4 (2003): 68, doi. org/10.1111/1468-229x.00282. Based on 1930 values, calculated through the UK National Archives' historical currency converter, which only goes up to 2017. Available at: www.nationalarchives.gov.uk/ currency-converter.

30 Aiken, 'Central Committee', 181.

31 Ibid., 182.
} 
Officials' treatment of unemployed women occurred against a backdrop of substantial pressure on the government to push more women into domestic service. In April 1923, the Daily Mail's 'Special Correspondent', Richard Curle, ran a series of four articles on 'Scandals of the Dole' in which he called for women to be refused benefits if they were 'capable of domestic service. ${ }^{32}$ By that time, the issue had 'become so intractable' that a committee had already been discussed and was appointed by the Minister of Labour, Montague-Barlow, in the same month Curle's article series was published. ${ }^{33}$ The resultant report on the 'Supply of Female Domestic Servants' was effectively a response to public pressure from the press and the middle class to investigate a supposed link between the payment of unemployment benefits and the lack of domestic servants. The 1923 report followed only four years after a similar investigation by the Ministry of Reconstruction on the 'Domestic Service Problem' in $1919 .{ }^{34}$ Unsurprisingly, the two reports had rather similar findings. The primary difference was that the 1923 report devoted an entire section to the 'Effect of the Unemployment Insurance Scheme on the Supply of Domestic Workers', with several pages of an appendix containing responses to complaints that had been made regarding women, domestic service and unemployment benefits. ${ }^{35}$

The purpose of this article, however, is to show that domestic service participation rates were not only driven by a top-down approach but that there was some degree, however limited, of complicity by working-class families - mothers in particular-in keeping women and girls in service. Among historians of the working class and domestic service in this era, Selina Todd stands out in her treatment of factors contributing to female participation in domestic service along similar lines to what is covered in this article. Her work taps into the intersection between class and young

32 Daily Mail, 10 April 1923, quoted in Horn, Life Below Stairs, 30.

33 Elaine Harrison, 'Women Members and Witnesses on British Government Ad Hoc Committees of Inquiry 1850-1930, with Special Reference to Royal Commissions of Inquiry' (PhD thesis, London School of Economics and Political Science, 1998), 204.

34 Ministry of Reconstruction (UK), Report of the Women's Advisory Committee on the Domestic Service Problem together with Reports by Sub-Committees on Training, Machinery of Distribution, Organisation and Conditions (London: HMSO, 1919).

35 Ministry of Labour (UK), Report to the Minister of Labour of the Committee Appointed to Enquire into the Present Conditions as to the Supply of Female Domestic Servants (London: HMSO, 1923), 25-35. See also 'Appendix D: Summary of Complaints Investigated', 42-53. 
women's labour in England, especially in the first half of the century. ${ }^{36}$ She also considers the part of mothers in their daughters' 'occupational aspirations' and pathways into the workforce, including domestic service, and references the interviews conducted by the Manchester Studies Unit in some of her writing. ${ }^{37}$ This article draws on Todd's excellent work but focuses strongly on the role of the structural disadvantage of working-class women and girls in explaining the perpetuation of domestic service in the aftermath of WWI, and how the war exacerbated that disadvantage, starting with why their employment was so desperately needed at a time when the male breadwinner model remained dominant.

\section{The Need for Women's and Girls' Employment}

With a younger brother at the front, Anna Bradley, aged 18 in 1914, 'wanted to do something' for the war effort. That 'something' was working on gas respirators for the duration of the war. Within a week of the Armistice, she had simply been made redundant from her job of four years and found herself looking for work at an Employment Exchange. She was offered a domestic service position, which 'at that time you couldn't refuse', given the scarcity of jobs. ${ }^{38}$

Attitudes of the interwar British government towards female unemployment — on both sides of politics — were predicated on a view of the primacy of male employment to families and society that was out of step with the contemporary working-class British reality. The concept of a male breadwinner earning enough to keep his wife and children became

36 Selina Todd, Young Women, Work, and Family in England, 1918-1950 (Oxford: Oxford University Press, 2005); Selina Todd, 'Young Women, Work and Family in Inter-War Rural England', The Agricultural History Review, 52, no. 1 (2004): 83-98; Selina Todd, 'Poverty and Aspiration'; Selina Todd, 'Domestic Service and Class Relations in Britain 1900-1950', Past and Present, 203 (2009): 181-204, doi.org/10.1093/pastj/gtp014; Selina Todd, 'Breadwinners and Dependants: Working-Class Young People in England, 1918-1955', International Review of Social History, 52, no. 1 (2007): 57-87, doi.org/10.1017/s0020859006002781; Selina Todd, “Boisterous Workers”: Young Women, Industrial Rationalization and Workplace Militancy in Interwar England', Labour History Review, 68, no. 3 (2003): 293-310, doi.org/10.3828/lhr.68.3.293.

37 Todd, 'Poverty and Aspiration', 136.

38 Domestic Service Interview with Mrs Anna Bradley, 21 January 1975, GB131.1103, Manchester Studies 41, TLSAC, Ashton-under-Lyne. Anna Bradley was born in Widnes, outside Liverpool, with the family moving to Manchester when her father got a job there. 
prevalent towards the end of the nineteenth century and still influenced government and societal attitudes towards male and female employment. As Hilary Land points out:

In the course of the nineteenth century the home and the workplace became separate for the majority of men and the unit of labour changed from the family to the individual. Married women were not expected to make an economic contribution to the household and if they did it was often not perceived to be 'productive' work. Men were assumed to earn a family wage. ${ }^{39}$

Despite men — and unions - using their need to earn a 'family wage' to justify demands for higher wages, many failed to earn enough to support a family. ${ }^{40}$ Contemporary studies found that up to 20 per cent of the interwar English working-class population lived below the poverty line. The employment of women and children was key to keeping families above that line. The need for their wages was exacerbated by circumstances created by WWI, including the death or injury of male breadwinners. ${ }^{41}$

Male deaths during WWI compelled many more women and children to take up paid employment than might otherwise have been the case. Estimates of British war deaths during WWI vary greatly, but a figure of around 700,000 is most commonly cited. ${ }^{42}$ Between 1911 and 1921, England and Wales saw an increase of 265,172 widows, from 1,364,804 to $1,629,976$. This compares to an increase of 118,397 over the preceding decade and 175,222 in the decade that followed. ${ }^{43}$ Correspondingly, the working female population increased by 10.4 per cent from 1911

39 Hilary Land, 'The Family Wage', Feminist Review, no. 6 (1980): 60.

40 Ibid., 56-7.

41 Todd, 'Breadwinners and Dependants', 64.

42 See Table 4 in J M Winter, 'Britain's "Lost Generation" of the First World War', Population Studies, 31, no. 3 (1977): 451; Dmitri Jdanov et al., 'Estimates of Mortality and Population Changes in England and Wales over the Two World Wars', Demographic Research, 13 (2005): 393-4.

43 Based on figures from the 1901, 1911, 1921 and 1931 Censuses for England and Wales. Census of England and Wales, 1901, Summary tables: Area, houses and population; also population classified by ages, condition as to marriage, occupations, birthplaces, and infirmities, BPP 1903 XXIX [Cd. 1523]; Census of England and Wales, 1911, Summary tables: Area, families or separate occupiers and population; also population classified by ages, condition as to marriage, occupations, tenements, birthplaces, and infirmities, BPP 1914-16 1 [Cd. 7929]; Census of England and Wales, 1921, Table 4: Occupations of Females Aged 12 Years and Over, distinguishing Twelve Age Groups, Marital Condition, Industrial Status and, for Certain Occupations, Those Working 'At Home'. (London, HMSO, 1921); Census of England and Wales, 1931, Table XLVIII: Occupations of Males and Females aged 14 and over: Proportions according to Marital Condition and Industrial Status, England and Wales, 1931 (London, HMSO, 1931). 
to 1921 , compared to 5.7 per cent for men. ${ }^{44}$ A much greater percentage of women were entering the workforce than men due to the far-reaching effects of WWI.

Ethel Cleary's Mancunian family was already poor when her father died in the war in 1918, when she was 10 . She left school at 14, as was common at that time, entering an enjoyable period employed at a confectioners' shop. This came to a swift end when she contracted a skin disease. The wife of the doctor treating her was in search of a servant, and between him and her mother she was 'just pushed into it without ... any preparation, without any warning ... I wasn't given any time to consider'. They were 'desperately poor' and needed the money, and she would not have thought to question her mother or an authority figure such as a doctor. Consequently, she moved away from her family to embark on the first of five different live-in servant positions. ${ }^{45}$ The war exacerbated her family's financial problems, effectively forcing her into domestic service.

Where husbands and fathers returned from the war, the psychological trauma, sometimes coupled with physical injuries, ailments or disabilities caused many to struggle to be fully functional as income earners. Official estimates placed the number of British war-wounded at $1,662,625 .{ }^{46}$ Physical injuries varied significantly, from amputated limbs, to facial disfiguration, to the limiting effects of lodged shrapnel. Due to its complex and hidden nature, the psychological cost of such a protracted war-paid for by ex-servicemen in their quality of life, productivity, employability and relationships-is impossible to calculate.

Reportedly, 80,000 British soldiers were treated for 'shell shock'-a form of post-traumatic stress—but 'many, many more suffered than were treated'. ${ }^{47}$ Norman Fenton, a psychologist who worked with the American Expeditionary Forces based in France, surveyed 758 men treated as 'psychological casualties' at the base in 1919-20 and again in 1924-25.

\footnotetext{
44 Aiken, 'Central Committee', 100.

45 Interview with Mrs Cleary.

46 The War Office (UK), Statistics of the Military Effort of the British Empire During the Great War, 1914-1920 (London: HMSO, 1922), 237.

47 James Bradley, 'Shell Shock Treatments Reveal the Conflict in Psychiatry's Heart', Conversation (6 August 2014), theconversation.com/shell-shock-treatments-reveal-the-conflict-in-psychiatrysheart-29822. Tracey Loughran points out that not all cases historically identified as shell shock would be diagnosed as post-traumatic stress disorder (PTSD) today. She asserts that PTSD is not 'simply shell shock by another name' but encompasses a specific set of symptoms. See: Tracey Loughran, 'Shell Shock, Trauma, and the First World War: The Making of a Diagnosis and Its Histories', Journal of the History of Medicine and Allied Sciences, 67, no. 1 (2012): 102-3, doi.org/10.1093/jhmas/jrq052.
} 
While the men were not British, it still provides an indication of the adjustment 'war neurotic' ex-servicemen faced when re-entering civilian life. ${ }^{48} \mathrm{O}$ those classified as 'neurotic', 22 per cent could work full-time but 'continued to suffer from one or more rather severe nervous difficulties'. The largest group, 38.9 per cent, were considered 'normal' and able to fulfil their role as breadwinners, but not without symptoms. However, nearly 40 per cent (the three worst-affected categories combined) were unable to work full-time or at all. ${ }^{49}$ Provision for their families would have to come from other sources.

Government pensions for veterans were inadequate to support a family, and income from wives and children was required to make ends meet. ${ }^{50}$ Further, psychological war injuries took a high toll on families. That those injuries were not visible, and how to treat them not apparent, could strain relationships to breaking point. Elizabeth Anderton, who grew up in Bolton, Greater Manchester, described her father as having 'died from the war'. He had been gassed and suffered from 'shell shock'. Her mother left him for another man after his return. Consequently, she and her two sisters were placed in a Waifs and Strays Home, from where she was trained for and sent out to service. ${ }^{51}$ This shows the vulnerability of working-class children to the indirect effects of war on family life, and how their parents' unwillingness or inability to care for them resigned girls to domestic employment.

Men who were not at the front also had their jobs affected as certain industries faltered due to the war's end, increasing families' reliance on female members' income. Molly Ducksbury's father worked for a ship building company after serving in the war. When the war ended, the company's licence was not renewed. ${ }^{52}$ While she had already left home for work as a servant at that point, the family needed the money she could contribute even more, given her father's sudden unemployment. His anger and drinking habits were, unsurprisingly, compounded by the loss of his job. His temperament, worsened by his war experience, likely contributed to her decision to move as far afield as London, from Newcastle, when she

48 Peter Leese, 'Problems Returning Home: The British Psychological Casualties of the Great War', The Historical Journal, 40, no. 4 (1997): 1060, doi.org/10.1017/s0018246x97007395.

49 Norman Fenton, Shell Shock and Its Aftermath (St Louis: The C.V. Mosby Company, 1926), 91-4, 97.

50 Leese, 'Problems Returning Home', 1056.

51 Domestic Service Interview with Mrs Elizabeth Anderton, 24 October 1974, GB131.1103, Manchester Studies 21, TLSAC, Ashton-under-Lyne.

52 Molly Ducksbury grew up in a working-class home in Jarrow, County Durham, in the 1900s-1910s. 
turned 14 in 1918 - the year her father returned from the war-and was able to leave school. ${ }^{53}$ Not only did an unemployed breadwinner compel women and children in the family to seek employment, domestic service provided girls with an employment option away from a difficult home situation that also came with accommodation and respectability.

\section{The Aversion to Employment in Domestic Service}

Some girls, like Molly Ducksbury, were keen to leave their family home for a domestic service position that was far afield, but many wanted to remain close to their families. This was among the reasons why women and girls were reluctant to take up domestic service, despite the ample supply of the work and their need for an income. In an era of increased awareness of workers' rights, an occupation that required a worker to be continuously and indiscriminately at the employer's beck and call had become untenable. In a memorandum included in the Ministry of Reconstruction's 1919 Report on the Domestic Service Problem, women's rights activist Lilian Harris expressed her disagreement with the committee's conviction that providing training was 'the most important question' in resolving the occupation's issues. Instead, she considered 'the lack of freedom arising from living in the employer's house' as the main cause of workers' objections and suggested a 'living out' system. ${ }^{54}$ Lack of free time, and lack of autonomy in what little free time they did have, left servants with few opportunities to socialise outside work, compounding the solitude of an already lonely job.

While a declining minority of servants were employed as part of a large domestic staff, the vast majority of servants were working in homes with only one or two servants. ${ }^{55}$ Not only was the burden of work on these

53 Domestic Service Interview with Mrs Molly Ducksbury, 28 January 1975, GB131.1103, Manchester Studies 35, TLSAC, Ashton-under-Lyne.

54 Report on Domestic Service (1919), 5-6. Lilian Harris came from a wealthy family but was very active in the women's and labour movements at that time. She was particularly involved in the Women's Co-operative Guild, an organisation that spread the co-operative movement but also participated in political campaigns for women's rights. Her partner, Margaret Llewelyn Davies, was a very successful general secretary of the Guild. See: Gillian Scott, Feminism, Femininity and the Politics of Working Women: The Women's Co-operative Guild, 1880s to the Second World War (London: Routledge, 2005), 13, doi.org/10.4324/9780203981344.

55 Todd, 'Domestic Service', 191. 
servants great, they wanted more opportunities for 'liberty in the evening. ${ }^{56}$ Recreation clubs to cater for servants' social needs were consistently suggested but of little use if employers were unwilling to allow servants the time to attend them. ${ }^{57}$ Such clubs were not to be exclusively for servants, so as to avoid 'undesirable social distinctions between domestic workers and others' ${ }^{58}$ The subservient nature of domestic service, especially when 'living in', had a decidedly adverse effect on the occupation's status in the eyes of the working class.

As detrimental as employers' attitudes towards their domestic employees were to the occupation, working-class girls and women often encountered the most negativity about 'being in service' from their peers. According to the Ministry of Labour's 1923 report on domestic servants, it was 'not so much the employers, as [maids'] own friends and relatives who look[ed] down upon domestic service. ${ }^{59}$ Author and middle-class occultist Violet Firth also pointed to 'the contempt in which servants [we] re held by their own class', but related it back to the treatment by employers. ${ }^{60}$ In a job where she was treated as inferior, Firth posited that the servant was 'despised by the girl who ha[d] found a trade in which she can sell her labour without selling her independence'. ${ }^{61}$

The negative perception of domestic service among the working class even influenced the desirability of servants as marriage partners. Ethel Cleary, from Manchester, worked as a servant in the 1920s and said that it was 'degrading' and 'quite low to go into service' at that time. ${ }^{62}$ Another former servant Irene Hudson and her husband agreed that there was a 'definite social stigma' attached to the occupation, as it was 'sort of a last resort work' - the one job 'any girl could get'. ${ }^{63}$ The other job options available to women meant that domestic service was seen as insecure, intolerable, or anachronistic as a social institution'. ${ }^{64}$ It was, therefore, unsurprising that female servants would hide being in service when first meeting a potential romantic interest-even lying outright about their

56 'Lack of Parlourmaids', Times (London), 9 June 1915, 11.

57 See Report on Domestic Service (1919), 4, 5, 12, 24,29 and Report on Domestic Servants (1923),

$8,18,34$.

58 Report on Domestic Service (1919), 25.

59 Report on Domestic Servants (1923), 11.

60 Firth, Servant Problem, 22.

61 Ibid., 21.

62 Interview with Mrs Cleary.

63 Interview with Mrs Hudson.

64 Delap, Knowing Their Place, 3. 
occupation. Mrs Arnold pretended to work in a factory, as servants 'were looked down on, there's no doubt about that'. ${ }^{65}$ Irene Hudson's husband defied his family outright by marrying her, a woman they thought beneath him on account of her being a servant. ${ }^{66}$

The popularity of the occupation was not improved by government attempts to coerce women into it. The domestic training centres set up by the CCWTE were concentrated in troubled regions, known as Depressed, Distressed or Special Areas, whereas the employers requiring the services of those being trained were not. The government identified the areas of South Wales, Scotland and England's North East (notably Durham) as 'suffering extreme hardships of unemployment'. These were 'highly specialised industrial regions' before WWI, with a concentration of heavy industries, such as steel, shipping and coal mining, that were harshly affected by postwar conditions. Through the training centres and Employment Exchanges, the government aimed to shift unemployed females from such 'unemployment blackspots' to areas with a high demand for servants. ${ }^{67}$

Rather than focusing on rejuvenating areas of high unemployment, the British government resorted to punitive measures to coerce the unemployed to take up jobs wherever they were to be found. As more young women in the South of England escaped from domestic service into factory work, those unemployed in the North were expected to replace them. Not only did this breed resentment-forcing girls and women into jobs they did not want in places they did not want to be-but it was not always effective. Some girls, though presumably not many, opted to forfeit their benefits rather than be coerced into taking faraway domestic jobs. ${ }^{68}$

The CCWTE's large-scale interwar recruitment and training drive was meant to link domestic employers seeking servants with unemployed women, decreasing the number of women claiming unemployment benefits. The British government's 1919 Report of the Women's Advisory Committee on the Domestic Service Problem identified training as the key to raising the status of the occupation and making it more attractive to

65 Domestic Service Interview with Mrs Arnold, 21 October 1975, GB131.1103, Manchester Studies 22, TLSAC, Ashton-under-Lyne.

66 Interview with Mrs Hudson.

67 Aiken, 'Central Committee', 181, 186, 211; Beddoe, Home and Duty, 62-4; Henry A Mess, The Present Position in the Distressed Areas', The Political Quarterly, 8, no. 3 (1937): 354.

68 Selina Todd, The People: The Rise and Fall of the Working Class, 1910-2010 (London: John Murray, 2014), 65. 
women and girls. ${ }^{69}$ It failed to take into account, however, the full remit of the reasons the occupation was so unpopular and why women refused to leave kith and kin to take it up.

Elizabeth Hughson was recruited for one such training centre in Manchester, the city where she lived with her family as one of 12, around 1923, when she would have been 19 . She protested, initially: 'I said no, I've got a good home, I got a good home, I don't want anything like that'. Her objections reflect the sentiment among the working class that domestic service was an occupation of last resort. Nonetheless, she was strongly encouraged to take the course in order to improve her chances of securing employment, which she did. She had suffered injuries to her eyes in a factory job that had left her unemployable for five years and with no other feasible option but domestic work. The training succeeded in increasing Elizabeth Hughson's employability as she was offered a job in London upon completing her course. Despite her need for work, she was able to decline it without penalty, and soon found another position closer to home. ${ }^{70}$ Women like Elizabeth Hughson did not willingly choose domestic service as an occupation, but were compelled to take it up due to pressure from authorities and lacking other options for earning a desperately needed income.

Working-class women were not necessarily any more enthusiastic about being domestic servants before WWI, but few employment alternatives existed for women then. According to Nellie Jones, born and raised in Marston, Cheshire, there 'were no factories' when she and her older sister started paid work just before the war, but there were plenty of factory opportunities by the time her younger sisters reached school-leaving age. ${ }^{71}$ The North had a longstanding history of factory employment before the war-even women and girls worked in Manchester's cotton mills. Mrs Jones' comment was likely the perception of a girl growing up in a rural part of one of the city's neighbouring counties. As war-related factories closed when the war ended, so did the avenue whereby many workingclass women and girls had managed to avoid domestic service. A big government push to return women to domestic service after WWI, to get them off 'the dole', and the use of punitive measures if they did not

69 Report on Domestic Service (1919), 7.

70 Domestic Service Interview with Mrs Elizabeth Hughson, 15 October 1974, GB131.1103, Manchester Studies 26, TLSAC, Ashton-under-Lyne.

71 Domestic Service Interview with Mrs Nellie Jones, 31 October 1974, GB131.1103, Manchester Studies 10, TLSAV, Ashton-under-Lyne. 
capitulate to that pressure-alongside the economic needs of workingclass families-saw a reluctant return to the unpopular occupation. The British government, however, had an unlikely partner in this campaign—working-class mothers.

\section{Working-Class Mothers and Their Daughters' Domestic Employment}

Many families could not risk losing what little government benefit their daughters were eligible for and encouraged them to take the domestic service opportunities presented to them by the Employment Exchange. Despite a preference to keep their daughters close and the potential dangers of sending them to live far away with strangers, parents knew they 'either did that or starve'. ${ }^{72} \mathrm{Mrs}$ O'Neil, one of 13 children, described the provision of room and board in both private and institutional domestic service as an important part of why girls, even those from 'nice, respectable families', took up domestic work. ${ }^{73}$ Decent accommodation and food, or the fear of it being worse elsewhere, kept some servants in positions where they were treated abominably. For those facing poor living conditions at home and whose families relied on their income, returning home was not an option. Conversely, those with a good home situation to which they could return felt less compulsion to stay where they were unhappy. ${ }^{74}$

For girls with no family home, there was little choice but service until they married. Those who were orphaned or separated from their parents, like Elizabeth Anderton, were trained for domestic service and posted out to positions from their children's home. Once they ceased to be a ward of the state and until they married, live-in domestic service provided them with a place to live that kept their marriageability intact. Therefore, despite the sexual vulnerability inherent in residential domestic service, it provided some perceived moral benefits. Anna Bradley affirmed this sentiment, reflecting on her time in service as a 'nice bringing up'. She felt that girls who struggled to adapt to the strictures of service were from less disciplined homes and preferred the (moral) freedom of factory work. ${ }^{75}$

72 Domestic Service Interview with Mrs O’Neil, 24 February 1975, GB131.1103, Manchester Studies 4, TLSAC, Ashton-under-Lyne.

73 Interview with Mrs O'Neil.

74 Interview with Mrs Hughson.

75 Interview with Mrs Bradley. While moral judgement is inherent to her response, it was much more indirect than its inclusion here might suggest. 
While some parents were reluctant to send their daughters away to residential service, others welcomed the opportunity to instil in them the discipline they considered to be lacking. As opposed to factory work, some working-class mothers viewed domestic service as 'a secure and respectable occupation'. ${ }^{76}$ The appeal of the occupation for some parents was its socially isolating nature that could curb a daughter's potential for moral misdeeds. The use of domestic service as a means of reforming young women and girls thought to be in need of it was not new but parents faced new challenges in managing their daughters' morality in the 1920s and 1930s. Greater leisure time and the consumption of media were seen to have a troubling effect on young women, particularly in relation to their morality. Contemporary social commentators feared that young women's exposure to romance magazines and the cinema was encouraging 'unreal expectations of life and unsuitable values', with the strongest criticism that of creating 'an unhealthy preoccupation with the opposite sex'. ${ }^{77}$

For many working-class parents struggling with the effects of those new influences on their daughters, the answer was domestic service, which 'curbed a daughter's liberty and thus protected her moral health'. ${ }^{78}$ While Anna Bradley welcomed the restrictions of 'live-in' service, preventing her getting 'into mischief', Mrs Sandys' mother used to 'threaten' her with service for that very reason..$^{79}$ Mrs Sandys, who grew up just outside Manchester between the wars, saw her mother eventually carry out those threats. Reflecting on it, Mrs Sandys felt that she was sent into service as a 'punishment' for being a 'tomboy' and not responding 'very well' to discipline at home. If addressing this was indeed the purpose of her time in service, it succeeded. Talking about one employer, Mrs Sandys said, 'I think she had broken my spirit completely, so I just became that ... I was very obedient-I didn't question anything - I did as I was told and life just went on'. ${ }^{80}$ In her case, domestic service succeeded as a means of moral reform, but at a clear cost to her mental and emotional health.

Despite putting Mrs Sandys in service for the occupation's disciplinary benefits, her mother would not allow her daughter to be mistreated. One weekend, while working in their local curate's home, Mrs Sandys

76 Todd, 'Young Women', 89.

77 Penny Tinkler, 'Cause for Concern: Young Women and Leisure, 1930-50', Women's History Review, 12, no. 2 (2003): 245-6, doi.org/10.1080/09612020300200359.

78 Todd, 'Poverty and Aspiration', 138.

79 Interview with Mrs Bradley; Interview with Mrs Sandys.

80 Interview with Mrs Sandys. 
experienced a 'very bad cold'. She recalled that, when they had had colds as children her mother usually plied them with homemade remedies, and they simply continued on with school and other activities. Therefore, she did not see the need to stop her work because she was sick. When her sister, who had gone to visit her, told their mother how Mrs Sandys was continuing to work in spite of being so poorly, the mother would not stand for it. The next morning, finding her daughter in a steam-filled wash house where she was doing the 'colossal usually weekly wash', her mother marched upstairs to the employer, with whom she then had a few words, before taking her child home with her. Mrs Sandys never found out what her mother had said to the curate's wife but had heard her tell others that her employer had been using her 'for a slave' and that she was adamant that 'none of [her] girls [would] slave as hard as [she had] slaved'. It was clear that, for some working-class parents, there was a limit to the kind of treatment they would allow their children to be subjected to in their work as servants, even if they were the ones pushing them into service in the first place. In a time when the demand for servants was great but the supply not, another position could easily be found. ${ }^{81}$

Mothers played a unique role in their daughters' pathway into domestic service, due — in large part — to the gendered nature of the work. They were sometimes accused by the servant-seeking classes of actively discouraging their daughters from taking up the occupation or simply not encouraging them enough to participate in housework. In defending teachers against accusations that they were advising girls against domestic service, Laura Shore, who described herself as a schoolmistress of 24 years, stated that teachers readily advised mothers on how to get their daughters into service. She described mothers' responses as varying from their daughters' complete lack of interest in domestic work to the extent to which the mothers did all the domestic work without demanding their daughters' help. This led Miss Shore to conclude her letter with the 'respectful' suggestion that, in discouraging girls from taking up domestic work, 'the fault [lay] nearer home than school'. ${ }^{82}$

In addition to initiating them into domestic work, mothers were also expected to guard their daughters' morality. While the 'high levels of control' that mothers exerted over their children before WWI became less stringent after the war, as Lucy Delap asserts, mothers were often

82 Laura Shore, 'Training Domestic Servants', Times (London), 19 June 1936, 139. 
still implicated in, especially, their daughters' moral failings ${ }^{83}$ As a result, mothers sometimes turned to domestic service, which had long since been seen as a means to instil moral discipline in 'wayward and troublesome girls' ${ }^{84}$ Female servant-employers and senior female servants were extended the authority of a parent and mandated with the role of moral protector over junior female servants that entered their employ. ${ }^{85}$

On occasion, the threat to a daughter's 'moral health' was not from outside sources, but from within the family home. Irene Hudson, of Manchester, was sent into service by her mother in the 1920s as a direct response to her alleging sexual advances from her stepfather. In her later interview, the language she used to describe the situation was vague, euphemistic and indirect, but its inference of sexual harassment and abuse was clear. She described the ways he disguised the sexual with playful physicality towards her that still inflicted pain. She had thought that he did not know his own strength, that he was 'uncouth', but it was likely an expression of his frustration. Other times, she recognised his 'playfulness' for what it was:

He occasionally chased me 'round the house, and, I was a bit green, I was very green, but I wasn't as green as that ... so I told my mother the first time for which — this is the first time in my lifethat she gave me a terrific slap across the face. Nearly knocked me senseless for telling lies. Well, the second time he did it, I think I got one on the other side of the face. I was absolutely terrified. And this time, she put an advertisement in the news. She got a hundred and twenty replies for a job for me, and it ended up with me going in service. ${ }^{86}$

While the extent of Irene Hudson's stepfather's sexual assault was unclear, her husband confirmed that 'he insinuated that my wife was very good looking. I can imagine that ... it was a problem, you know' ${ }^{87}$ What was clear was the stepfather's verbal and emotional abuse. He belittled her, claiming she would 'end up on the streets' and that domestic service was

83 Delap, Knowing Their Place, 32.

84 Paula Bartley, Prostitution: Prevention and Reform in England, 1860-1914 (London: Routledge, 2000), 94

85 Delap, Knowing Their Place, 29.

86 Interview with Mrs Hudson.

87 Mr Hudson was present at the interview with Mrs Hudson. 
all she was 'fit for'. He demanded that the five pounds of potatoes be 'done just right' as he walked into the house every night and prevented her leaving the house on Sundays or having friends visit. ${ }^{88}$

Domestic service provided Irene Hudson with a haven from her oppressive home life. She not only found her first place of employment 'heaven' as it involved minimal housework and looking after a little girl who was 'absolutely a dream', she even described the physical experience of walking from her home to her employer's home 'like going to heaven'. She literally walked uphill from the dirt and industry of her working-class home to the greenery and fresh air of Higher Broughton. ${ }^{89}$ Yet despite escaping physically, the emotional toll of her stepfather's bullying and her mother's rejection and emotional abandonment left Irene Hudson with indelible psychological scars. She started to internalise their behaviour towards her: 'you see, in the end, my treatment was such that I thought there must have been something really terrible about me'. This sense seemed to permeate her work life. She was repeatedly drawn to families who sought to control her as her own family did, that in the end 'I used to feel lower and lower and lower and lower, they were slowly crushing the life and spirit out of me'. One life event that countered this negative self-belief was her husband defying his family in marrying her, as they thought he was lowering himself in marrying a servant. ${ }^{90}$

Economic imperatives were undoubtedly the main drivers for workingclass parents pressing their daughters into domestic service. Moral concerns, however, played their part in the preference of mothers-as the gatekeepers of their children's morality-for domestic service over other occupations. A high value was still placed on the marriageability and respectability of young women at this time, demanding a vigilance about their moral behaviour that did not apply to boys or men. These gendered ideas around morality combined with the gendered nature of domestic service-especially 'live-in' service, with its long hours and limited opportunities for socialising - to produce a solution for workingclass parents concerned for their daughters' moral wellbeing. Sexual vulnerability was inherent to residential domestic service, yet that did not prevent some parents from treating domestic service as a deterrent to immoral behaviour.

88 Interview with Mrs Hudson.

89 Ibid.

90 Ibid. 


\section{Conclusion}

Following WWI, women like Northwich-born Rose Mutch, who was proud of a family legacy of domestic service and felt it was 'in [her] blood', were swiftly being replaced by those like Mrs Arnold who was 'determined that [her] children would never go into service'. ${ }^{91}$ Nevertheless, some working-class families played an active role in coercing their daughters into taking up domestic service when it was becoming an increasingly unpopular occupation. While elements of a family history in service or the practical benefits of domestic service as training for a woman's presumed future role in marriage remained, parents were more likely to be pushing their girls into paid domestic work for more pragmatic reasons and immediate concerns.

Their daughters' employment in domestic service not only provided families with much-needed income, but the 'live-in' nature of the work, which was still the norm in the 1920s, provided the board and lodging that most new employment options did not. This remained a great boon to families who were struggling to house and feed all their children. And, as this article has shown, getting a daughter out from underfoot could separate her from the young men with which she might be tempted to fraternise and from men in her own home who posed a threat. The role of working-class parents in facilitating the perpetuation of domestic employment after WWI was likely small but clearly some did aid the British government's attempts to address female unemployment through training and punitive measures to compel women to take up 'hated domestic service'. ${ }^{22}$ While the government made decisions for workingclass women as one homogenous group, the parents' decisions-which were not necessarily made in the daughter's best interest-were based on the specific circumstances of their family and their daughter. Their decision-making was informed by working-class economic realities and gendered moralities that were worlds apart from the government's motivations.

91 Domestic Service Interview with Mrs Rose Delena Mutch, 27 January 1975, GB131.1103, Manchester Studies 5, TLSAC, Ashton-under-Lyne; Interview with Mrs Arnold.

92 Beddoe, Home and Duty, 49. 


\section{BOOK PANEL}





\section{Debating Patriarchy}

Julia Adams, Benita Roth and Pavla Miller

This piece is an updated set of panel contributions on Pavla Miller's book Patriarchy (Routledge, 2017) at the Social Science History conference in Phoenix, Arizona, in 2018.

Miller's brief book is part of the Routledge Key Ideas series, which covers the main concepts, issues, debates and controversies in sociology and the social sciences. The blurb summarises the book as follows:

Patriarchy, particularly as embedded in the Old and New Testaments and Roman legal precepts, has been a powerful organising concept with which social order has been understood, maintained, enforced, contested, adjudicated and dreamt about for over two millennia of Western history. This brief book surveys three influential episodes in this history: seventeenth-century debates about absolutism and democracy, nineteenth-century reconstructions of human prehistory, and the broad mobilisations linked to twentieth-century women's movements. It then looks at the way feminist scholars have reconsidered and revised some earlier explanations built around patriarchy. The book concludes with an overview of current uses of the concept of patriarchy from fundamentalist Christian activism, over foreign policy analyses of oppressive regimes, to scholarly debates about forms of effective governance. By treating patriarchy as a powerful tool to think with, rather than a factual description of social relations, the text makes a useful contribution to current social and political thought. ${ }^{1}$

The panellists included Julia Adams and Benita Roth.

1 Pavla Miller, Patriarchy (London; New York: Routledge, 2017). 


\section{Julia Adams: Patriarchy Resartus}

Patriarchy is back. The concept, that is. Readers may recall Steve Bannon's over-heated words, delivered after he had watched Oprah Winfrey's speech about Harvey Weinstein and his ilk at the Golden Globes:

It's primal. It's elemental. The long black dresses and all that-this is the Puritans. It's anti-patriarchy. If you rolled out a guillotine, they'd chop off every set of balls in the room ... Women are gonna take charge of society. And they couldn't juxtapose a better villain than Trump. He is the patriarch. The anti-patriarchy movement is going to undo 10,000 years of recorded history. ${ }^{2}$

So Pavla Miller's slender, meaty book, in Routledge's Key Ideas series, is timely. All too timely, perhaps.

Patriarchy adopts a couple of major tacks to narrow this huge topic. First, it focuses on 'the West', an increasingly ambiguous but broadly understood term. Second, it pursues some salient highlights of how people have used the concept of patriarchy, rather than trying to explore in any detailed way the relationship between theory and empirics. For Pavla Miller, patriarchy is 'a powerful set of conceptual tools with which social order has been understood, maintained, enforced, adjudicated, and dreamt about for over two millennia of Western history'. That is a reasonable focus, and the textuality of the author's choices seem completely defensible. One needs to draw boundaries in the genre of the theoretical essay (150 pages or less). This genre, seemingly so limiting, is also thereby freeing: since it is impossible to 'do justice' to any topic in such a constricted length, the writer has a lot of say-so, with aspects that they themselves care about coming to the fore. Think John Berger's Ways of Seeing, for example, another great feminist theoretical essay. ${ }^{3}$ The broad-brush approach necessarily invites quibbles, of course, so my comments will mention areas of critique as well as things that I love about the book.

But first I want to note that Pavla Miller has been working with the concept of patriarchy for a long time. Many will necessarily read this book in light of Miller's earlier, excellent Transformations of Patriarchy in the West, 1500

2 Charlotte Higgins, 'The Age of Patriarchy: How an Unfashionable Idea Became a Rallying Cry for Feminism Today', Guardian, 22 June 2018, www.theguardian.com/news/2018/jun/22/the-ageof-patriarchy-how-an-unfashionable-idea-became-a-rallying-cry-for-feminism-today.

3 John Berger, Ways of Seeing (New York: Penguin Random House, 1990 [1972]). 
1900. ${ }^{4}$ The first part of that text explored what is the historical mid-section of the present book: the moment of early modern patriarchalism and the shift to fraternalism, via the wave of great European revolutions that kicked off in the eighteenth century. Throughout Miller argued that the concept of patriarchy had its problems, but still did a decent job of capturing the range of early modern tutelary and governance relations, those linking not just fathers and children, and rulers and subjects, but also husbands and wives, masters and servants, and even, initially, some capitalists and workers. Miller was most influenced by Carole Pateman, herself building on Sir Robert Filmer, the social contract tradition, and Sigmund Freud. Thus the big political story is the transition from absolutist father-rule to fraternal revolutions that excluded women from the nascent public sphere. Miller's take was more attuned to political economy than Pateman's-for example, that earlier book also surveys 'challenges to patriarchy that derived from economic changes such as proto-industrialisation and groups such as the journeymen's guilds and Masons that were masculinist, but not patriarchal'. She also noted that the concept was deployed within and across these varied early modern relationships, by the actors themselves, so presented a picture of contradiction and struggle rather than tidy stage-sequential development. But the basic political-conceptual story is the overthrow of father-rule by the lateral alliance of brothers.

Perhaps the existence of this earlier book is why the advent of modernity in the West gets such short shrift in Patriarchy (just five pages), basically boiled down to Jean Bodin, Filmer, Rousseau and Pateman, though Miller returns to the legacy of Max Weber's concept of patriarchal patrimonialism at the end of the book, including my and Mounira Charrad's work, and her own terrific essay on Australia's patriarchal patrimonial 'squattocracy' in one of our coedited volumes. ${ }^{5}$ Why linger on this centuries-long 'moment' in a conceptual-theoretical story of millennia of Western patriarchy? It was a meaningful and deeply influential transitionincluding in the history of the concept and associated practices itselfand it is one with which we are still grappling in the historical present.

4 Pavla Miller, Transformations of Patriarchy in the West, 1500-1900 (Bloomington: Indiana University Press, 1998).

5 Pavla Miller, 'Antipodean Patrimonialism? Squattocracy, Democracy and Land Rights in Australia', in Political Power and Social Theory: Patrimonial Capitalism and Empire, Vol 28, eds. J Adams and M M Charrad (Emerald Group Publishing Limited, 2015), 137-63, doi.org/10.1108/s0198871920150000028006 . 
In this general 'patriarchal/familial' conceptual approach, as Isaac Reed and I have noted, patriarchy and its fraternalist conceptual cousin is a crucial category of analysis and practice. ${ }^{6}$ Modernity emerges, in part, as the result of fathers attempting to ensure the legacy of family lineages. They act on behalf of their future sons, their vision of their ancestors, and the powerful ideology of father-rule itself. They do so through strategic marriages and alliances, lineal property holding, and inventing collective capacities to possess and control state offices and privileges. As an unanticipated consequence, they help usher in modernity and in particular modern statehood. As father-rulers, uniting to preserve their respective lineages, these patriarchs create what turn out to be not only bureaucratic ruleregulated forms and lateral practices of political collaboration, but also norms of fraternity. This explains a great deal about the character of state building and patterns of state dissolution, and specific gendered forms of anti-monarchical violence in the great revolutions, including the French Revolution. Furthermore, although this mechanism does not by itself explain the nature of the public sphere or the variety of institutions that characterise democratic societies, it illuminates why so many ostensibly individualist or neutral public institutions in fact embody masculinist norms and legacies.

Max Weber's concept of 'patriarchal patrimonialism' is one fount of this perspective. Feminist theories of cultural patriarchy (e.g. Joan Landes on the French Revolution) are another. ${ }^{7}$ As I have just articulated it in shorthand here, it applies mostly to elites. But Joan Landes' theory of cultural patriarchy in the French Revolution is fundamentally about its basis as a cross-class political alliance. And the patriarchal modus operandi stands no chance of reproduction without enabling a great chain of social being in which men - those who are deemed men rather than something more disqualified — of the lowest orders have some symbolic and practical possibility of participating. This is precisely where the history of even the concept of patriarchy again intersects forcefully with race, ethnicity and class. But when and how does the patriarchal form become detached from actual fathers and sons and become a working metaphor for governance in situations that are not ideal-typically patriarchal? How do contemporary

6 Isaac Reed and Julia Adams, 'Culture in the Transitions to Modernity: Seven Pillars of a New Research Agenda', Theory and Society, 40 (2011): 247-72, doi.org/10.1007/s11186-011-9140-x.

7 Max Weber, Economy and Society, 2 vols, trans. Guenther Rot (Los Angeles: University of California Press, 1968 [1922]); Joan Landes, Women and the Public Sphere in the Age of French Revolution (Ithaca, NY: Cornell University Press, 1988). 
patriarchal patrimonial states, in which these relations are encoded in law_-and patriarchal politico-legal projects, such as Donald Trump'sinteract with representatives of modern postpatriarchal formations? And to return and take off from Pateman, how do we separate the wheat from the chaff, detaching the 'false abstract universalism' of the rationallegal, the conflation of the paternal with the human and sexual with contractual control, without losing the liberal individual, and the idea of self-determination? In these fundamental ways, that eighteenth-century moment is still with us.

An aside: this is not to suggest that Western patriarchy stopped dead in 1800. In fact, just as Pavla Miller urges us, it is important to consider whether there are essential aspects of modernity-or should I say modernities plural — that are essentially patriarchal. Is there such a thing as a Fordist patriarchy, for example? Contrary to the Marxist tradition, which named and developed the concept, patriarchy could be construed as a core ingredient of the Fordist political economy that underwrote the American Century. ${ }^{8}$ In Henry Ford's vision of the automobile factory, the workers who worked on the assembly line for what was then a generous $\$ 5$ a day wage would then be able to purchase its products. As the Fordist production-consumption cycle was generalised and came to characterise mid-century American manufacturing, it grounded a crossracial working-class ideal of the father-worker identity; the fraternalism of male associationalism in trade unions and the like, and a gendered spatial incarnation of the public/private split. At its most dramatic, this ideal was incompletely available to all, but remained a resonant cultural ideal, whose demise haunts present-day American politics.

In pre- or early modern Western societies, family lineage was co-extensive with authority and the imagined future of society. How do those living in modern societies explicitly and publicly imagine the future? They certainly do not do so solely through the scrim of sons-and-sons' sons. In modernity, in other words, it has seemed that the power of patriarchy cannot constitute an alluring or comforting imagined future. Or ... have we only mistaken this? For another indication that the concept is coming back to the fore is that the absence of father-rule is being lamented, whether by those in power or at least some of those who feel themselves

8 Antonio Gramsci, 'Americanism and Fordism', in Selections from the Prison Notebooks of Antonio Gramsci, eds. Quentine Hoare and Geoffrey Nowell Smith (New York: International Publishers, 1971). See also Bob Jessop, 'Fordism', Encyclopedia Britannica (Sage Publications). 
disempowered and abandoned. Recently, for example, The New York Times ran a striking article on 'angry East German men fuelling the Far Right', the men who were left behind, demographically and otherwiseby the women who fled to West Germany after the Wall came down, and from rural tracts to urban centres - and who excoriate Angela Merkel as a cause. ${ }^{9}$ Like the North American INCELs, there is even an element that calls for the forcible redistribution of women-Elementary Structures of Kinship revisited but in fascist form. ${ }^{10}$ What do we make of this, analytically? Where do we stand, as democratic intellectuals?

In closing, to begin with, let me underline three important things that I really like about this book. First, over the course of 30 pages (pp. 53-83), 'Patriarchy and the Making of Sisterhood', it restores complexity to 1960s-1970s-era feminist theoretical thought, too often caricatured these days. This is the period when the focus shifted from the huge civilisational narratives particularly beloved of nineteenthand early twentieth-century thinkers to people (women, mostly) trying to make sense of the relationship between structures and practices of male domination and capitalism. Friedrich Engels wrote about both'the world historical defeat of the female sex' - as well as the relationship between production and reproduction, and he was a major inspiration, as Miller notes. ${ }^{11}$ So one set of 1970 s-era debates revolved around whether the fundamental dynamics of the capitalist mode of production reside in the contradiction between the forces and relations of production, or relations between production and the market, or whether the linked but relatively autonomous organisation of production and reproduction are the driving forces of development and crisis. Another set of related debates tried to determine the role of women's household labour in capitalist development and political struggle. These debates had major practical political outcomes-and they also shaped academic debates across the disciplines.

9 Katrin Bennhold, 'One Legacy of Merkel? Angry East German Men Fueling the Far Right', The New York Times, 5 November 2018, www.nytimes.com/2018/11/05/world/europe/merkel-eastgermany-nationalists-populism.html.

10 Claude Levi-Strauss, The Elementary Structures of Kinship (New York: Beacon Press, 1969 [1949]).

11 Friedrich Engels, The Origin of the Family, Private Property and the State (New York: Penguin Random House, 2010 [1884]). 
We are not so far past this analytical moment as we sometimes think, because, again, we're not past it historically. For example: what kind of 'gender order' do we inhabit in contemporary capitalism, in the United States, comparatively, and global-transnationally? What are its features, fissures, dynamics, futures? How should we orient ourselves to it, as academics or otherwise? Is patriarchy at all helpful in tackling these questions? A recent paper by Eric Mace in Social Politics argues that 'composite gender arrangements' are a better conceptual lens. ${ }^{12}$ Have even the political institutional spaces that so uneasily interlock reached a level of complexity that they are no longer articulated by any version of fatherrule, or even male dominance? What does Pavla Miller herself think, I wonder? Patriarchy is scrupulously neutral on this important point.

Second, I greatly appreciate Patriarchy's attention to social psychologyand to the social and social-psychological as two sides of one analytical coin, as it were. True, I would have liked that to be marked with respect to the concept throughout the entire historical arc under examination. Instead, this important feature emerges when textually thematised, with the theorists of patriarchal subjectivities - that is, Freud, Jacques Lacan, Nancy Chodorow, Dorothy Dinnerstein, to name a few. Nonetheless, it is extremely important to have it there, and it constitutes an important ground with which people will engage with the book and with the question of whether patriarchy is of the vintage of the truly longue durée, and if so, from whence that longevity emanates. I would in addition note that if scholars are going to think this expansively, collectively, they will also need to rigorously examine the relationship between the social-historical domain and co-evolving empirical areas, concepts and theories that have generally been deemed beyond its boundaries, such as the 'natural' and 'biological'.

Third, I very much like the way that the book situates itself, deconstructively at the end, in empire and the contemporary global and transnational turn, thereby tracing not simply its own but many of our collective theoretical limitations. But what are the implications for the book's own starting point, which flags the Bible and the Roman Empire? For the development of the

12 Eric Mace, 'From Patriarchy to Composite Gender Arrangements? Theorizing the Historicity of Social Relations of Gender', Social Politics: International Studies in Gender, State \& Society, 25, no. 3 (2018): 317-36, doi.org/10.1093/sp/jxy018. See also Ann Shola Orloff and Renee Monson, 'Citizens, Workers or Fathers? Men in the History of US Social Policy', in Making Men into Fathers: Men, Masculinities and the Social Politics of Fatherhood, ed. Barbara Hobson (New York: Cambridge University Press, 2002), 61-91, doi.org/10.1017/cbo9780511489440.004. 
Western patriarchal concept itself, which first appeared in an imperial setting? The book's own geographic and cultural ambit, the West, is not simply one that is mainly European core and its contemporary imperial extensions, but those that are primarily coded as 'Western' only because the European part of that legacy remains culturally dominant. And it does so because there, in these now nationally contained spaces, the genocidal effects and even deliberate projects of European settler colonialism were most thoroughgoingly effective. This is certainly true among the Englishspeaking colonies: the United States, Canada, Australia and New Zealand are all exemplars. I am not contending that it is illegitimate to focus on these spaces. But it would be well for us to remember that the persistence of the patriarchal conceptual heritage of Roman Law, for example, is if anything even more fraught than represented here.

And yet, at its best, what is known as Western feminism continues to raise the banner for some of the cherished legacies of these struggles. And to fight not simply on behalf of women, but on behalf of all-men very much included - for the right to be an individual, to be considered a full social and legal person. The right to be 'seen', socially recognised and respected. To be paid equally. To be able to have a family, or not. To be remembered. To be free.

\section{Benita Roth: Patriarchy and Intersectionality: The Price of Popularity and the Project of Recovering Meaning}

To prepare for the 2018 'author meets critics' panel of Pavla Miller's book Patriarchy, I asked an academic friend if she used the concept in her work or teaching. She answered 'yes', but also commented 'I've never had to define it super carefully'. I also thought about how I, a feminist intersectional scholar, didn't use the concept in my work. In stark contrast, a Turkish graduate student of mine could not have written her dissertation on agrarian reform and Turkish women's land occupations during the Green Revolution without writing often of the 'patriarchal', in terms of how households were formed, in analysing power relations in villages, towns, and in describing Turkish government programs. 
Reading Miller's book clarified for me why my Turkish student needed to wrestle with patriarchy as an analytical concept and why I hadn't. We do know that patriarchy is a key idea for some (many?) feminist scholars; one of the issues Miller tackles in this book is how and when the idea of analysing gender through a lens of patriarchy was attractive to feminist (and other) scholars. Miller is interested in how the term patriarchy has been used and what conceptual work it was expected to perform ... the book treats patriarchy as a powerful tool to think with, rather than a factual description of social orders'. ${ }^{13}$ She argues that the meaning of patriarchy has not been fixed over the years. Miller covers three 'episodes' in the history of conceptualisations of patriarchy (among Anglophones): seventeenth-century debates about absolutism and democracy, nineteenth-century reconstructions of human prehistory, and the broad mobilisations linked to twentieth-century women's movement. Miller does not have as her end goal a definition of patriarchy as such; rather, she is interested in continuities and discontinuities in how scholars and activists assessed the state of male rule over women. Miller hints that for some (many?) feminists, 'patriarchy' as a concept has been emptied of meaning, citing as an example historian Leila Rupp's objections to the way that the use of the term obscures that which needs to be explained. ${ }^{14}$ Miller does see the concept of patriarchy as having content, and at the same time agrees with Cynthia Enloe: '[p]atriarchy ... is not a sledge hammer being swung around a raving feminist head. It is a tool; it sheds light at the same time as it reveals patterns of causality ... "it reminds us we are investigating power"'. ${ }^{15}$

As scholars we have seen this process of the popularisation of concepts to the point of meaninglessness before, and continue to see it. A similar process of popularisation into meaninglessness is happening to 'intersectionality', as it has travelled beyond the US academy into other scholarly spaces and the non-academic press. I want both concepts-patriarchy and intersectionality - to co-exist, but not as empty of meaning, and so I had two main reactions in reading Miller's book as a feminist intersectional scholar. First, I wanted more discussion about the 'patriarchal bargain' and how that concept has been used as a tool to assess the everyday decisions

13 Miller, Patriarchy, 1.

14 Ibid., 92.

15 Ibid., 103. 
made by women within structures of inequality. ${ }^{16}$ Second, I wanted some discussion by Miller about the way in which 'intersectionality' has come to be seen as an alternate framework for feminist investigations of power.

To the first point, Turkish scholar Deniz Kandiyoti put forward the concept of 'the patriarchal bargain' in her 1988 article 'Bargaining with Patriarchy'. To simplify, Kandiyoti argued that women uphold patriarchal norms in order to gain some power/resources in households. I've seen the concept used overtly and implicitly in studies as diverse as Arlie Hochschild's landmark The Second Shift, ${ }^{17}$ Susan Mannon's 2017 book City of Flowers: An Ethnography of Social and Economic Change in Costa Rica's Central Valley; ${ }^{18}$ Lisa Wade's article on the sociology blog site 'The Society Pages', where she analysed Serena Williams' decision to play up her sexuality so as to avail herself of 'the heightened degree of fame and greater earning power we give to women who play by these rules'; and, of course, my student's dissertation. ${ }^{19}$ Maybe the use of 'patriarchal bargain' by disparate feminist scholars means that the concept is also empty of rigour, but it seems useful for many because we must spell out the terms of the bargain, highlight how accommodation and contestation with male dominance is continually made by women, and so we explore the bargain's specifics. This seems consonant with Miller's view of patriarchy being a disputed and changing analytic tool.

On the second point of addressing intersectionality, Miller does note that intersectionality 'became an influential way of simultaneously attending to issues of race, gender, and class'. She defines intersectionality by way of other authors, stating that the concept 'is an attempt to elevate and make space for the voices and issues of those who are marginalised and a framework for recognising how class, race, age, ability, sexuality, gender, and other issues combine to affect women's experience of discrimination'. ${ }^{20}$ But Miller fails to recognise that intersectionality represents an alternative framework for feminist analysis, one that in US

16 Deniz Kandiyoti, 'Bargaining with Patriarchy', Gender \& Society, 2, no. 3 (1988): 274-90.

17 Arlie Russell Hochschild with Anne Machung, The Second Shift (New York: Avon Books, 1990).

18 Susan Mannon, City of Flowers: An Ethnography of Social and Economic Change in Costa Rica's Central Valley (Oxford: Oxford University Press, 2016).

19 Lisa Wade, 'Serena Williams' Patriarchal Bargain', The Society Pages, 22 May 2011, thesocietypages. org/socimages/2011/05/22/women-damned-if-you-do-damned-if-you-dont/.

20 Miller, Patriarchy, 89. 
feminist realms has largely replaced patriarchy as a conceptual means of understanding domination. Intersectionality seems to make patriarchy too one dimensional, too focused only on gender.

And yet intersectionality seems to be losing some analytical utility, even as it becomes more popular, perhaps due to what sociologist Kathy Davis has called its 'ambiguity and open-endedness'. ${ }^{21}$ Perhaps it is the case that neither concept—patriarchy or intersectionality—can be deployed without care. Vrushali Patil argues that the framework of patriarchy has been displaced by intersectionality, and sees the latter as an improvement, but she also argues that intersectionality retains some of the shortcomings of patriarchal analysis, such as: 'the uncritical acceptance of the nation as a necessarily meaningful unit of analysis for feminists', and the limits of intersectional 'attention to cross-border dynamics'. ${ }^{22}$ Patil wants more attention to the transnational and the transpatial in feminist intersectional analysis, citing the moment of UN General Assembly debates over decolonisation being shaped by what Patil calls 'contending patriarchal metaphors'. ${ }^{23}$ Patil then calls for 'an approach the production of various patriarchies as intersectionalities emergent from multiple histories of local-global processes, or as emergent from layers of multiple locals and globals that exist relative to and in relation to each other'. ${ }^{24}$ Patil fills the content of intersectionality with the content she thinks they should have, while employing a similar strategy to Miller's of analysing episodes of public consequential debates about meaning.

I would argue that recapturing meaning for both concepts-patriarchy and intersectionality-relies on thinking of either (both?) concepts as lens, and so I appreciate Miller's historical exploration of patriarchy. Since we are now in the age of 'intersectionality studies', let me just note that the idea of intersectionality as methodological lens fits with what the originator of the term Kimberlé Crenshaw, along with co-authors Sumi Cho and Leslie McCall, see as its future. They write that intersectionality is:

21 Kathy Davis, 'Intersectionality as Buzzword: A Sociology of Science Perspective on What Makes a Feminist Theory Successful', Feminist Theory, 9, no. 1 (2008): 67, doi. org/10.1177/1464700108086364.

22 Vrushali Patil, 'From Patriarchy to Intersectionality: A Transnational Feminist Assessment of How Far We've Really Come’, Signs, 38, no. 4 (2013): 851, doi.org/10.1086/669560.

23 Patil, 'From Patriarchy to Intersectionality', 849.

24 Ibid., 863. 
best framed as an analytic sensibility ... What makes an analysis intersectional-whatever terms it deploys, whatever its iteration, whatever its field or discipline - is its adoption of an intersectional way of thinking about the problem of sameness and difference and its relation to power. This framing - conceiving of categories not as distinct but as always permeated by other categories, fluid and changing, always in the process of creating and being created by dynamics of power-emphasizes what intersectionality does rather than what intersectionality is. ${ }^{25}$

To use either patriarchy or intersectionality in a meaningful way means deploying it as method; the scholar makes decisions about which lens to use; about the nature of socially salient categories, and their interpenetration; about the histories of power configurations; and about the interplay between ideologies of power and their incarnations as practices. I don't want to supplant Miller's project of understanding the debates around patriarchy with one about understanding the debates around intersectionality. Both projects are necessary, and since Miller takes us on the road toward recapturing the utility of patriarchy, I welcome her effort.

\section{Pavla Miller: Where Next?}

In 2005, the US sociologist Julia Adams published an important book dealing with the history of patrimonial politics in the Netherlands. Her argument was that elite family patterns and dynamics first fuelled that country's spectacular rise in the emergent world economy of the eighteenth century, and its decline a 100 years later. In effect, Adams argued, the power of elite patrician families stymied the transformation of political power from one sort of patriarchy to another, something that became necessary in order to compete with other emerging nation-states on the world stage. ${ }^{26}$

In commenting on her book several years ago, I admired her achievement, but asked for more social history, and in particular for more material on changing relations between economies, family dynamics, and demographic patterns. My own book, Transformations of Patriarchy in the West, 1500-1900, sketched out some of these patterns and relations, but

25 Sumi Cho, Kimberlé Williams Crenshaw and Leslie McCall, 'Toward a Field of Intersectionality Studies: Theory, applications and praxis', Signs, 38, no. 4 (2013): 795.

26 Julia Adams, The Familial State: Ruling Families and Merchant Capitalism in Early Modern Europe (Ithaca, NY: Cornell University Press, 2005). 
was of necessity limited by my knowledge of world history and social theory. ${ }^{27}$ The Patriarchy book was in part motivated by an attempt to better understand the key concept I used in my previous work. As diligent essay writers would do, I initially tried to find a satisfactory definition of patriarchy. A fruitless search, spanning several years, finally led to a simple insight: what I was trying to achieve could not be done. There were simply too many people-feminist, non-feminist and anti-feminist—using the term in often powerful and insightful but finally incompatible ways. Theorists who valiantly tried to reconcile this messy literature proved unconvincing - both to me and to a wider scholarly audience. Armed with this realisation, I sidestepped debates about whether patriarchy remained a useful feminist concept and what precisely it meant, and researched how it had been used in different important episodes of Western history.

The project has provided me with an apparently obvious answer to Roth's suggestion that to use either patriarchy or intersectionality in a meaningful way means deploying the concept as a method. ${ }^{28} \mathrm{I}$ disagreed. As far as I could tell from my reading, the causality tended to go the other way around. Feminists with extensive training in one of the social sciences (myself included) tended to be guided by the conventions of their discipline and their scholarly preferences and affiliations. Even activists using what could be called vernacular sociology use the concept of patriarchy in many different ways, informed by local traditions of dissent and theorising. Intersectionality did suggest a more coherent method, but even here what writers and activists actually did was dependent a great deal on their background, education and social movement experience. In all, as Roth herself put it in an earlier paper: 'What we have come to understand is that the second wave was comprised of feminisms, plural: organisationally distinct feminist movements that developed and grew along different paths'. ${ }^{29}$

Careful reflection, and re-reading of some of Roth's work, produced a more nuanced answer. A powerful and widely shared narrative does indeed associate the term patriarchy with a particular approach to activism and research. As a shorthand summary, patriarchy denotes men's

27 Miller, Transformations of Patriarchy in the West, 1500-1900.

28 Benita Roth, Separate Roads to Feminism: Black, Chicana and White Feminist Movements in America's Second Wave (Cambridge, UK: Cambridge University Press, 2004), doi.org/10.1017/ cbo9780511815201.

29 Benita Roth, 'Second Wave Black Feminism in the African Diaspora: News from New Scholarship', Agenda, 17, no. 58 (2003): 46. 
enduring and pervasive oppression of women. Under patriarchy, men are the main perpetrators of violence and oppression, and women the victims. Less developed countries and ethnic groups tend to have a stronger patriarchy, and so warrant patronising interventions by their more civilised, enlightened and liberated peers. Women's shared experience of subordination gives rise to a universal sisterhood, and logically points to a linked series of questions, approaches and categories. Together, these amount to a feminist research method.

My Patriarchy book-and indeed much of Roth's work on feminist movements-attempted to dismantle this schematic (and often racist) account, together with the narrow methodological choices it implied. And yet, in answer to Adams' question, the enduring strength of the shorthand summary, not just in popular discourse and activist politics but among scholarly colleagues and friends, for a long time led me to tone down or cease using the concept of patriarchy in my own work. After all, who was I to redefine the implications and uses of a powerful and widely used term?

Would intersectionality, as Roth suggests, provide a better feminist conceptual tool? Certainly, attention to diverse and interlinked forms of oppressive and unequal relations is a good thing. As a shorthand activist tool, intersectionality is far superior to one-dimensional focus on the oppression of women as an undifferentiated group by 'men' or 'patriarchy'. As one online definition puts it: If feminism is advocating for women's rights and equality between the sexes, intersectional feminism is the understanding of how women's overlapping identities-including race, class, ethnicity, religion and sexual orientation-impact the way they experience oppression and discrimination. Roth herself has emphasised that Black feminists in the US began organising at the same time that white ones did; they just did not join white groups. The failure by authors of earlier case studies to recognise early Black feminist organising has led to idea that white feminism was a template that Black feminists later used, or one from which they 'deviated'. By the same token, Roth notes, a deep understanding of the intersectionality of oppressions was part of Black feminist thinking from its inception. While I do not believe that intersectionality, of itself, provides a coherent method, it has made a powerful and lasting contribution to 'provincialising' Western social and political thought, and highlighting the strengths of 'southern theory'. Together with many other voices and theoretical contributions, intersectionality has helped shake the certainty of white privileged thought. 
Bargaining with patriarchy, Roth suggests, is another useful tool in assessing the everyday decisions made by women within structures of inequality. I agree that the term represents another particularly useful and productive metaphor. Those subject to the mastery of others, it suggests, do not lack agency. Rather, of necessity, they deploy it in ways less likely to spark off violent retaliation. Here again, a user-friendly and widely employed conceptual tool has contributed to a broad effort, both in social sciences and diverse forms of activism, to take respectful account of the agency of those often regarded as passive victims. More broadly, individual and collective bargaining with patriarchy, as Adams and I both argued, has at times led to fundamental transformations of existing forms of (patriarchal) social governance.

In her comments on Patriarchy, Adams returns to this broad area of research. She takes it as read that patriarchy is historically variable, involves forms of both imperial and class-based domination, concerns both gender and generational relations, and is fuelled by the agency of both rulers and ruled. Given her interest in early modern state formation and the rise of modernity, she wants more material on how precisely was legal rational authority infused with what could be called the transgenerational rule of fathers, and beyond that how patrimonialism and fraternalism infused the making of societies we now recognise as modern. I agree that these are important and exciting questions. I also endorse the complicated program of research on the gendered making of modernity in her Theory and Society article with Isaac Reed, even though I would supplement it with materialist dynamics - the changing balance between populations, technologies, forms and relations of production, and natural resources, the results of both purposive action and unintended consequences. ${ }^{30}$ Such a wildly ambitious project can benefit from the impressive accumulation of research since our respective books were published. Among many other things, it can be informed by debates on gendered welfare state regimes, maternalisms and racial formations.

So, to answer Adams' question, yes, I believe that the concept of patriarchy remains a useful category of analysis, not least as a reminder of the many discursive, cultural and institutional traces previous uses of the term have left in everyday life. How, for example, do notions of mastery and social infancy derived from legal codifications of the rights of patriarchs 
affect women and men, the young and the elderly, those with disabilities, indigenous peoples and those from diverse cultural backgrounds - and in different regions and jurisdictions?

I want to conclude with two sobering thoughts. First, a more sophisticated theory does not necessarily lead to better and more effective social action. Conversely, those armed with complex experience and shorthand vernacular sociology can achieve profound results, even if they lack academic sophistication and get their historical facts seriously muddled. Second, large projects dealing with historical transformations of patriarchy, the overlapping and interdependent systems of discrimination and disadvantage, or the activism of subaltern populations, need to be a collective rather than individual undertaking. As Rayna Rapp put it in 1977, 'It will easily be decades before the feminist critique can do for us what a Marx, a Weber, a Freud, a Lévi-Strauss have done for their areas of inquiry'. ${ }^{31}$ Yet the point of feminist critique was fundamentally different from the process 'by which individual men, stunningly well-educated as scholars, and totally confident of their mission as critical thinkers, redefine a tradition, and give it a new direction'. ${ }^{32}$ Rather than trying to replicate this highly individualist project:

What we are now attempting is something at once less grand and more consciously collective. For if we are children of the patriarchs of our respective intellectual traditions, we are also sisters in a women's movement which struggles to define new forms for social process in research and in action. ${ }^{33}$

31 Raina Reiter Rapp, 'The Search for Origins: Unravelling the Threads of Gender Hierarchy', Critique of Anthropology, 3, no. 9-10 (1977): 16.

32 Rapp, 'The Search for Origins', 16.

33 Ibid. 


\section{BOOK REVIEWS}





\title{
Three Lively Feminist Lives
}

\author{
Rosa Campbell \\ University of Cambridge
}

\section{Germaine: The Life of Germaine Greer \\ Elizabeth Kleinhenz \\ (Sydney: Penguin Books, 2019, 432pp., \$24.99) ISBN: 9780143782858}

\author{
Winning for Women: A Personal Story \\ lola Mathews \\ (Clayton, Victoria: Monash University Publishing, 2019, 328pp., \$29.95) \\ ISBN: 9781925835151
}

\author{
Unfettered and Alive: A Memoir \\ Anne Summers \\ (Sydney: Allen \& Unwin, 2018, 496pp., \$39.99) ISBN: 9781743318416
}

These three books chronicle the lives of Australian feminists Germaine Greer, Iola Mathews and Anne Summers. By way of brief introduction: Summers is one of Australia's best-known feminists. She was part of the collective that founded Elsie, the first women's refuge in Australia, and in 1975 she authored the Australian feminist classic Damned Whores and God's Police. ${ }^{1}$ Summers also worked as a journalist in Australia and internationally, and as a political advisor at the highest level of government to improve the lives of Australian women. Unfettered and Alive is the second volume of her autobiography, which begins in 1976 where her first, Ducks on the Pond (1999), ends. ${ }^{2}$ Iola Mathews started her career as a journalist at The Age and was one of the founding members of the Women's Electoral Lobby (WEL), an organisation that sought reform of party politics along feminist lines. She also worked at the Australian Council of Trade Unions (ACTU) where she pursued equal pay and paid parental leave. Germaine Greer wrote what is sometimes called 'the classic text of the [women's] movement' The Female Eunuch (1970) and is a global celebrity, thinker and provocateur. ${ }^{3}$

\footnotetext{
Anne Summers, Damned Whores and God's Police (Hammondsworth: Penguin, 1975).

Anne Summers, Ducks on the Pond: An Autobiography, 1945-1976 (Melbourne: Viking, 1999).

Elizabeth Kleinhenz, Germaine: The Life of Germaine Greer (Sydney: Penguin, 2019), 5.
} 
As these books reveal, the lives of these women were tangentially intertwined. Summers and Mathews worked together at the Office for the Status of Women, and Mathews describes Summers as a frank-speaking, supportive, 'tall woman with a formidable intellect'. ${ }^{4}$ Summers met Greer only once, at a party thrown by a Sydney Push member to celebrate the birthday of Chairman Mao. Summers had drunk too much Jim Beam: 'a drink I have never tried before (or since)'. She threw up in front of Greer, who looked at her with a mixture of 'disdain and compassion'. Mathews never met Greer, except in print when she read The Female Eunuch (1970). Mathews admits the book was life changing for many women, but she was deterred because of 'its angry, in your face tone'. ${ }^{6}$ To reduce their connections to the times they encountered each other would be to deny their most profound entanglement: all three women were driven to spend their lives agitating for greater freedoms for women and all were central to, and shaped by, the Women's Liberation movement.

As an historian of Women's Liberation, I asked a particular question of these books, namely what they add to our understanding of Australian women's liberation history. I discovered that these volumes offer an insight into the profound change the Women's Liberation movement made on women's lives, but also how slow and uneven this change could be-even for those at the centre of this social movement. These books also reveal how important the global currents of Women's Liberation were to the Australian movement and the difficult relationships between individual feminists and the rest of the movement.

The early lives of all three women stand in stark contrast to what they later achieved as feminists. Kleinhenz paints a picture of Greer's childhood, the drama of a violently abusive mother and an emotionally absent father who pathologically lied, played out against the backdrop of lower middle-class Melbourne suburbia. ${ }^{7}$ Summers grew up in the 'staid' suburbs of 1950 s Adelaide, and her father was a violent alcoholic. ${ }^{8}$ This is considered in the first volume of her autobiography Ducks on the Pond, but her upbringing

4 Iola Mathews, Winning for Women: A Personal Story (Melbourne: Monash University Publishing, 2019), 141.

5 Anne Summers, Unfettered and Alive: A Memoir (Sydney: Allen \& Unwin, 2018), 349. The Sydney Push were an exuberant, libertarian group. On Greer's relationship to the Push see Elizabeth Kleinhenz, Germaine: The Life of Germaine Greer (Sydney: Penguin Books, 2019), 64-74.

6 Mathews, Winning for Women, xii.

7 Kleinhenz, Germaine, 11-44.

8 Summers, Unfettered and Alive, xii. 
shadows Unfettered and Alive too. ${ }^{9}$ Mathews' family was more nurturing and was peppered with unconventional women, although her father still upheld the rigidly gendered values of the time where to be a real woman you had to be 'a homemaker' who 'made a man feel good'. ${ }^{10}$

Historians have established that the Women's Liberation movement swept profound changes throughout Australia at the level of politics, society and culture. ${ }^{11}$ These three volumes reveal that on a personal level this change was often uneven and frustratingly slow, even for those who were at the helm of the movement. Mathews, who had been a successful journalist and central figure in WEL, movingly describes the difficulties of raising two children at home, while her husband furthered his career as a politician in the Australian Labor Party. ${ }^{12}$ Despite her desire to live as a liberated woman, she found herself on the edge of a breakdown, frustrated she was unable to live as she wanted. While she had a feminist awakening, political and social structures were slower to change. It was difficult for women to pursue a career and have children because maternity leave could not be shared between partners. Her book satisfyingly charts her central role in championing paid parental leave policies, which were finally enshrined in law in $1990 .{ }^{13}$ Summers recalls her shock at not being able to place a deposit on a house in the late 1970s because, some 10 years after the Women's Liberation movement had taken hold, banks still upheld the sexist 'blanket rule' that meant ' $[\mathrm{w}]$ omen could not borrow' and needed a male guarantor. ${ }^{14}$ In Greer's case, it was men in the counter-culture who were resistant to change, even after The Female Eunuch had sent shockwaves across the world. Greer had an exploitative experience after she had sent self-made pornographic images to anti-censorship magazine Suck-including one of her in a yoga-pose ... splayed legs thrown back over her shoulders' - on the understanding they would be published

\footnotetext{
9 Ibid., 163.

10 Mathews, Winning for Women, 5.

11 See, for example, Marilyn Lake, Getting Equal: The History of Australian Feminism (Sydney: Allen \& Unwin, 1999); Michelle Arrow, The Seventies: The Personal, the Political and the Making of Modern Australia (Sydney: NewSouth Publishing, 2019); Michelle Arrow and Angela Woollacott, eds., Everyday Revolutions: Remaking Gender, Sexuality and Culture in 1970s Australia (Canberra: ANU Press, 2019), doi.org/10.22459/er.2019.

12 Ibid., 68-75.

13 Mathews, Winning, 213-31.

14 Summers, Unfettered and Alive, 85.
} 
alongside those of the other editors. But it was only her image that was published by the editors and then 'hawk[ed] ... around the Frankfurt bookfair. ${ }^{15}$

These books also reveal how profoundly Women's Liberation in Australia was inspired by Women's Liberation elsewhere, especially in the US, Europe and the UK. Australian feminist reading material was sourced almost entirely from overseas and all three had read, or tried to read, Simone de Beauvoir's The Second Sex (1949). ${ }^{16}$ All were profoundly influenced by Betty Friedan. Indeed, Greer suggests that she wrote The Female Eunuch in critical response to The Feminine Mystique (1963). For Williams, it was Friedan's The Second Stage (1981) that spoke to her, with its belief that 'hope lay with the new breed of younger men who were pushing prams and ... washing up'. ${ }^{17}$ Often international literature was directly translated into movement tactics at home. Foucault's Discipline and Punish (1975) inspired Summers, anti-carceral activism, as well as her award-winning journalism about the routine violence meted out to prisoners in New South Wales jails. ${ }^{18}$ Summers later worked as editorin-chief for glossy feminist magazine $M s$, and comments that it was 'something of a status symbol for Australian feminists to brandish the latest issue of [the] magazine'. But it was more than this. Mathews and other WEL members did the hard work of translating the Ms magazine survey of US political candidates' attitudes toward women's issues across contexts, rolling an equivalent survey out in Australia. ${ }^{19}$

As the Women's Liberation movement was inspired by texts from elsewhere, many feminists in the 1960s and 1970s went abroad. Many opted for the UK but also Europe and the US, as both Greer and Summers did. ${ }^{20}$ Greer travelled to Cambridge, where she began postgraduate study and Summers to New York, where she pursued her dreams of writing, working as a journalist and eventually for $M s$. Greer grew up thinking of England as 'the centre' and so was inspired to leave by the 'uncomfortable

15 Kleinhenz, Germaine, 157.

16 Summers, Unfettered and Alive, 438-9; Mathews, Winning for Women, xi; Kleinhenz, Germaine, 304.

17 Mathews, Winning for Women, 117.

18 Summers, Unfettered and Alive, 21, 23.

19 Summers, Unfettered and Alive, 209; Mathews, Winning for Women, 25.

20 This phenomenon is explored in Rebecca Jennings and Liz Millward, "A Fully Formed Blast from Abroad"? Australasian Lesbian Circuits of Mobility and the Transnational Exchange of Ideas in the 1960s and 1970s', Journal of the History of Sexuality, 25, no. 3 (2016): 463-88, doi.org/10.7560/ jhs25304; Summers, Unfettered and Alive, 65; Kleinhenz, Germaine, 84. 
feeling that her own country could never fully nourish and sustain her'. ${ }^{21}$ Greer's perspective is one of 'cultural cringe' explained by A A Philips in his pathbreaking 1950 essay. ${ }^{22}$ Historian Katie Pickles explains this as the understanding that 'Australia has no worthwhile culture distinguishable from Britain, that it held no ... vitality and that ideas must be sought from elsewhere' ${ }^{23}$ However, when living in England, Greer's 'Australianness' was a great boon as she was not beholden to the stringent British class system, as revealed when she talked her way onto a $\mathrm{PhD}$ program at the University of Cambridge. ${ }^{24}$ Women more oriented to the movement, such as lesbianfeminist activist Jill Johnston, were more than a little perturbed when the 'glamourous, impudent foreigner from Australia' was the drawcard to the famous Town Hall Debate with Norman Mailer in April 1971. ${ }^{25}$

Summers' account of leaving Australia is more ambivalent. On one hand she says, 'I thought I came from a lively and interesting place, I was well versed in ... the concept of the cultural cringe' and 'rejected the idea that Australians had anything to apologise for'. ${ }^{26}$ But still she left, because to 'make it' in New York was not the same as succeeding in Sydney. She suggests that her 'outsider status' along with her 'courage enabled her to succeed'. She, and fellow Australian Sandra Yates, 'achieved what no American woman had done', and independently bought out $M s$, along with the teen magazine Sassy. ${ }^{27}$ However, this outsider status led to the resale of both $M s$ and Sassy after just two years. This was partly a result of having underestimated how successful an organised consumer boycott of Sassy by Women Aglow, a right-wing women's group, would be: 'we were blindsided ... there were just too many things we didn't understand about America'.$^{28}$ She travelled back to Australia to begin her work as political advisor to the new prime minister, Paul Keating.

21 Kleinhenz, Germaine, 84.

22 A A Philips, 'The Cultural Cringe', 1950, meanjin.com.au/blog/the-cultural-cringe-by-a-a-phillips/.

23 Katie Pickles, 'Transnational History and Cultural Cringe: Some Issues for Consideration in New Zealand, Australia and Canada', History Compass, 9, no. 9 (2011): 658-9, doi.org/10.1111/ j.1478-0542.2011.00794.x.

24 Kleinhenz, Germaine, 85.

25 Jill Johnston, Lesbian Nation: The Feminist Solution (New York: Simon \& Schuster, 1973) 19; quoted in Kleinhenz, Germaine, 177-8.

26 Summers, Unfettered and Alive, 59.

27 Ibid., 247.

28 Ibid., 275. 
While the lives of all three women were profoundly changed by the Women's Liberation movement, their books make clear the difficult relationship these feminists had with it. Mathews' and Summers' recollections offer insight into the wide-ranging debate in Australian feminism between women who favoured reformist tactics, sometimes called 'femocrats', and those who felt that change could only occur through a grassroots movement external to the state. ${ }^{29}$ Mathews, who agitated for change from inside what were often very hierarchical structures such as government departments and trades unions, recalls the difficulties of working with grassroots collectives who valued consensus over efficiency. ${ }^{30}$ Summers' discussion of working for the Office for the Status of Women reveals the difficult task of representing all Australian women, such as when she was faced with understandable scepticism from non-Anglo women that she, a white woman, could understand and adequately represent their issues to government. ${ }^{31}$

Given the rich seam of scholarship discussing the way that the women's liberation movement negotiated-and sometimes failed to negotiaterace and racism, it is worth noting that aside from the anecdote above, Summers' and Mathews' works are largely silent on this question. ${ }^{32}$ Toward the end of Germaine, Kleinhenz discusses Greer's widely criticised culturally relativist view on female circumcision and her controversial views on Aboriginal Australian politics expressed in her essays White Fella Jump Up (2003) and On Rage (2008); but these opinions seem to be just two more explosive media controversies among many. ${ }^{33}$ Kleinhenz does intriguingly mention Greer's earlier relationships with Aboriginal people and her travels with Aboriginal rights activist and poet Roberta 'Bobbi'

29 See, for example, Hester Eisenstein, Inside Agitators: Australian Femocrats and the State (Philadelphia: Temple University Press, 1996), xv, 67-131; Sara Dowse, 'The Women's Movement's Fandango with the State: The Movement's Role in Public Policy Since 1972', The Australian Quarterly, 54, no. 4 (1982): 324-45, doi.org/10.2307/20635188; Marian Sawer, Sisters in Suits: Women and Public Policy in Australia, (Sydney: Allen \& Unwin, 1990); Angela Woollacott, 'Being a Women's Adviser at the State Level: Deborah McCulloch and Don Dunstan in 1970s South Australia', Australian Feminist Studies, 33, no. 95 (2018): 97-113, doi.org/10.1080/08164649.2018.1498736.

30 Mathews, Winning for Women, 109-10.

31 Summers, Unfettered and Alive, 159.

32 See, for example, in the Australian context: Christina Ho, 'Diversifying Feminism: Migrant Women's Activism in Australia', Signs, 33, no. 4 (2008): 777-84, doi.org/10.1086/528742; Jackie Huggins, 'A Contemporary View of Aboriginal Women's Relationship to the White Women's Movement', in Australian Women and Contemporary Feminist Thought (Oxford: Oxford University Press, 1994), 70-9; Aileen Moreton-Robinson, Talkin' Up to the White Woman: Aboriginal Women and Feminism (Brisbane: University of Queensland Press, 2000); Tikka Jan Wilson, 'Feminism and Institutionalized Racism: Inclusion and Exclusion at an Australian Feminist Refuge', Feminist Review, 52, no. 1 (1996): 1-26, doi.org/10.2307/1395769.

33 Kleinhenz, Germaine, 321-2, 347-53. 
Sykes. ${ }^{34}$ Given this, as well as Greer's convivial relationship with AfricanAmerican feminist Florynce Kennedy, explored by historian Rebecca Sheehan, and her visit to Iran at the invitation of the Women's Association in 1974, I wondered if more could be said about negotiations of race and the women's movement in all three texts. ${ }^{35}$

Summers' and Kleinhenz' books discuss the difficulties of negotiating fame and celebrity within the Women's Liberation movement. When Summers was appointed editor-in-chief of $M s$, she also had difficulties with the American Women's Liberation movement, particularly 'feted local celebrity' Gloria Steinem. ${ }^{36}$ Steinem, a founder of $M s$, continued to have a significant amount of unspoken control throughout the time Summers was editor. ${ }^{37}$ These relationships between Summers and famous American feminists were made more complicated as she was tasked with making a failing magazine, based on the collectivist principles of the 1970 s, function in the more capitalistic, less collectively minded 1980s. ${ }^{38}$ Germaine recalls Greer's savvy use of the media, much to the chagrin of other feminists. Kleinhenz teases out the question of whether or not Greer developed this media image for herself, or whether it was to enable feminist ideas to reach beyond the confines of the movement to ordinary women. Kleinhenz quotes Greer who said, 'the only reason ... I ever submit to the commercialisation of Germaine Greer is to help women in the home ... to spread the movement on the widest possible base. ${ }^{39}$ While this intention may have been true at one time and reflected in the widespread success of The Female Eunuch, Greer's relationship to the movement for gender justice has only become more vexed due to her use of the media. Her position on transgender issues, which Kleinhenz discusses towards the end of the book, reveals a significant failure to listen and learn, in order to generate publicity and maintain her status as a provocateur. ${ }^{40}$

\footnotetext{
34 Ibid., 346.

35 Rebecca J Sheehan, 'Intersectional Feminist Friendship: Restoring Colour to the Second-Wave Through the Letters of Florynce Kennedy and Germaine Greer', Lilith, 25 (2019): 76-92. On Greer's tour to Iran see: Rachel Buchanan, 'The Iran Album (1974): Some Sleeve Notes', Archivaria, 85 (2018): 124-54; Nima Nighibi, Rethinking Global Sisterhood: Western Feminism and Iran (Minneapolis: University of Minnesota Press, 2007) 74-108.

36 Summers, Unfettered and Alive, 247.

37 Ibid., 247, 225.

38 Ibid., 205-85.

39 Kleinhenz, Germaine, 183.

40 Ibid., 357-60.
} 
Each of these books makes a worthy contribution to the history of the Australian Women's Liberation movement. Considered together they offer insight into the way that Women's Liberation played out in the personal lives of individual women who were central to it. They also reveal the importance of global flows to Women's Liberation in Australia and the interesting, complex and intimate relationship between these feminists and the rest of this movement for social change. 


\title{
Female Genital Cosmetic Surgery: Deviance, Desire and the Pursuit of Perfection
}

\author{
Paige Donaghy \\ University of Queensland
}

Female Genital Cosmetic Surgery: Deviance, Desire and the Pursuit of Perfection

Camille Nurka

(Switzerland: Palgrave Macmillan, 2019, 268pp., AU\$100) ISBN: 9783319964898

As an historian of early modern European medicine and gynaecology, I have always wondered why physicians and anatomists of the period so frequently wrote about women's unwieldy, even 'monstrous' labia minora, clitorises and vulvas. Camille Nurka's fascinating monograph, Female Genital Cosmetic Surgery: Deviance, Desire and the Pursuit of Perfection, answers many of my questions through close historical analysis across antiquity, the medieval, early modern and modern period. Nurka is concerned with examining the historical consolidation of the modern medical term 'labial hypertrophy', which denotes a so-called abnormal length of the inner labia minora (abnormal in its supposed overextension past the labia majora). Twenty-first-century gynaecologists-and especially feminist gynaecologists-have recently established that this term is problematic, based on the medical view that there is no real 'normal' length for labia. However, cosmetic surgeons in the US, UK and Australia continue to perform huge numbers of non-medically necessary cosmetic labiaplasties. (Medically necessary labiaplasties, which are recommended by gynaecologists on medical and scientific grounds, are not in contention in this book.) Nurka rightly identifies that cosmetic surgeons are economically invested in maintaining this 'diagnosis', and through continuing to uphold the idea of abnormal labia, they are able to capitalise on women's genital anxieties. Moreover, these surgeons, unable to argue that such procedures are medically necessary, have recourse to 
shame by comparing large labia minora to elephant ears, and, conversely, also to feminist languages of autonomy, arguing that it is empowering for women to get labiaplasty to control their bodies. Yet, as Nurka notes, the lucrative medical idea of women's 'genital normality' (3) has a history, and its embeddedness in social discourses of female beauty, optimisation, bodily ideals, sexual pleasure and femininity, is the product of this history.

Nurka begins by analysing what the ancient Greeks had to say on women's labia to determine whether these ideas sprung from this period. Nurka identifies that writers like Hippocrates, Galen and Soranus were not particularly concerned with excessive labia, and concludes that 'labial hypertrophy did not exist as a clinical problem' for these authors (48). However, as Nurka examines in Chapter 2, the Galenic term 'nymphae', which incorporated both the clitoris and labia, emerged more prominently in medieval and early modern medical discourse and was transformed. Ancient Greek writer Aetius's ideas about 'hypertrophied' clitorises were co-opted in the Renaissance period by anatomists like the famous Vesalius (65-66). Vesalius extended concepts of hypertrophy to the labia, and he repeated Aetius's fables about Egyptian women who had these labia cut off due to enlargement (66). This association of unnatural, excessive labia with African women was then repeated ceaselessly by medical writers, both 'learned' and popular, through the sixteenth to eighteenth centuries (71). This was, Nurka argues, the origin of 'our current norm' that the labia minora should not extend past the majora (72).

Nurka follows this discourse into the eighteenth and nineteenth centuries in the next chapter. Nurka analyses how the medieval and early modern racialised fables of African women's hypertrophic genitals became legitimised in the new anthropological and anthropometrical sciences (84-85). During the nineteenth century, Nurka finds there was a European medical and social fascination with the 'Hottentot Apron', a racist term coined by Dutch colonists to describe Indigenous Khoisan women's labia (86-87). The reproduction of descriptions and illustrations of this 'apron' within European medical, gynaecological and social literature, Nurka argues, functioned to create a 'normalised invisible white female sexuality through the spectacular depiction of aberrant black bodies' (84). Nowhere was this clearer than in the case of Sarah Baartman, a Khoi woman 'brought to London in 1810 to be exhibited as a circus attraction, later becoming known as the "Hottentot Venus" (89). Nurka demonstrates how this colonising approach to African women's bodies by European scientists continued into the twentieth century, with a chapter on 'anthropometry' 
(the mathematical study of the human body). For example, Nurka discusses French gynaecologist Félix Jayle's 'highly detailed categories of vulval types from measurements taken from his female patients' (127). Jayle argued that hypetrophic labia were only found in black women, and if found in white women, it 'was a sign of racial degeneration' (127). Nurka goes on to situate these ideas within broader eugenic discourses that were utilised in Europe during the twentieth century, in which labial variation was seen as 'white racial degeneration' (153). Nurka argues that this history shows we cannot separate 'the very definition of labial hypertrophy' from the 'racist discourses through which it came to attain its meaning as excessive [or] bestial' (112).

The next chapter canvasses twentieth-century sexological approaches to women's labia, with a case study on the work of Robert Latou Dickinson, who argued that masturbation was a cause of labia hypertrophy. Nurka also details the work of sexologist giant Alfred Kinsey (164). The final chapter and conclusion represent Nurka's theorisation about the history of labial 'hypertrophy', modern discourses about genital cosmetic surgery and female genital cutting (FGC). Nurka provides a compelling analysis of debates about FGC, white Western cosmetic surgery practices and 'feminising' surgeries on intersex infants to argue that these practices are bound within a continuum of racial and gendered manifestations of 'normality' (213-32). Nurka suggests, using psychoanalytic concepts of fantasy and belonging, that 'cosmetic surgeries and cutting rituals produce magical transformations that provide a social identity' (231). Nurka's conclusion reiterates how historically men have 'demarcate[ed] biological boundaries between normal and abnormal femininity' (244). But instead of finishing her study on this sombre fact, Nurka discusses recent political-artistic efforts to debunk labial myths like the 'Labia Library', which provides us with a 'feminist' reimagining of vulvas not grounded in misogynistic or racist origins (248-54). Nurka's own project contributes substantially to building this reimagining.

Historians of science, medicine, the body and gender will find Female Genital Cosmetic Surgery a rich and illuminating case study in the power of medicine to define, maintain and enact 'normality', through its classificatory processes, institutions and claiming of authority over the body. Finally, feminist historians and theorists will find in Nurka's work an instructive example of feminist approaches to historical research, and a reminder of the dissembling and reconstitutive promise of queer and feminist methodologies. 



\section{Notes on Contributors}

Julia Adams is a Professor of Sociology and International \& Area Studies and Head of Grace Hopper College at Yale University. Her current research focuses on large-scale forms of patrimonial politics; the historical sociology of agency relations and modernity; and gender, race and the representation of academic knowledge on Wikipedia and other digital platforms.

Jenny Caligari is an experienced secondary school history teacher of 24 years and a recent graduate of $\mathrm{PhD}$ in History from Deakin University, Australia. She is currently employed by Deakin University as a casual academic for the Humanities team. Her research interests encompass the life of Bessie Harrison Lee, suffrage and temperance campaigner, nineteenth-century women's and transnational history. Her present work focuses on the life of Bessie Harrison Lee, Daylesford-born Woman's Christian Temperance Worker, famous for her public oratory. Bessie's life is used as a lens to explore women's social campaigning, lecturing, and writing and travel experiences. Jenny is a descendant of Victorian Premier James Munro who worked with the WCTU to attempt to achieve women's suffrage through the Monster Petition of 1891. His wife and Bessie are key signatures of the petition.

Rosa Campbell is the Smuts Scholar for Commonwealth Research at the University of Cambridge. She is in the second year of her $\mathrm{PhD}$, for which she considers the global history of the Australian women's liberation movement. She writes fiction and non-fiction for adults and children and has written recently for Novara, Overland and the Independent newspaper. She has just finished a book for children about the history of International Women’s Day. She tweets at @rosa_v_campbell.

Toni Church is a museum curator, and $\mathrm{PhD}$ candidate with the University of Notre Dame Australia. Her creative thesis combines her passion for telling women's stories with her professional museum experience (and she promises it will be finished soon). 
Rebecca Louise Clarke is a Monash University $\mathrm{PhD}$ candidate, a Museums Victoria research associate, and a Robert Blackwood Partnership Award fellow. Rebecca has taught at various Victorian universities and presented her work at local and international conferences. She authored the film criticism book The Monkey's Mask: Film, Poetry and the Female Voice (ATOM publishing) and has been published in poetry, film and cultural studies journals. Currently, her work explores memory, emotion, museums and motherhood.

Paige Donaghy is a $\mathrm{PhD}$ candidate in History at the Institute for Advanced Studies in the Humanities and School of Philosophical and Historical Inquiry at the University of Queensland. Her research examines the intellectual and cultural history of the 'false conception', or false pregnancy, within European scientific communities and societies across the period 1600-1800. Her other research interests include the history of pregnancy loss, early modern women's sexuality and feminist historiography, and she has an article on women's masturbation in Journal of the History of Sexuality. She is an Editorial Collective Member of Lilith: A Feminist History Journal and a Postgraduate Representative on the Cultural Studies Association of Australasia Executive Committee. Find her on twitter: @donaphy.

Belinda Eslick is a casual academic in gender studies at the University of Queensland in Brisbane, Australia. Her research explores ways of reconceptualising women's non-institutional and non-party political activity, drawing from historical and contemporary examples of women's political activity in Australia. She also engages more broadly with perspectives in feminist philosophy and theory, and particularly with the work of French feminist philosopher Luce Irigaray.

Kerrie Handasyde lectures in religious history at the University of Divinity where she is also an Honorary Postdoctoral Associate researching women's history in the church and the history of religion in Australia. She is a member of the steering committee of the Australian Collaborators in Feminist Theologies and serves on the committee of the Religious History Association. She is currently preparing a monograph, God in the Landscape: Themes in the Literary History of Australian Protestant Dissent (Bloomsbury, forthcoming), and a volume of essays edited with Cathryn McKinney and Rebekah Pryor, Contemporary Feminist Theologies: Power, Authority, Love (Routledge, forthcoming). 
Jessie Matheson is a $\mathrm{PhD}$ candidate working on the Invisible Farmer Project (ARC Linkage LP160100555) at the University of Melbourne, in partnership with Museums Victoria. Her research is on cultural histories of gender and sexuality in Australia across the twentieth century. Her thesis explores the political identities of Australian rural women.

Pavla Miller is Professor Emerita of Historical Sociology at RMIT University in Melbourne. Her publications include Long Division: State Schooling in South Australian Society and Transformations of Patriarchy in the West, 1500-1900. She has also published on demographic explanations of low fertility, masters and servants legislation, and conceptualisations of children's work.

Benita Roth is a Professor of Sociology, History and Women's Studies at State University of New York, Binghamton, where she is director of the Women, Gender and Sexuality Studies program. She is the author of Separate Roads to Feminism: Black, Chicana, and White Feminist Movements in America's Second Wave and The Life and Death of ACT UP/LA: AntiAIDS Activism in Los Angeles in the 1980s and 1990s. Her wider research focuses on the interaction of gender, race/ethnicity, sexuality and class in post-war US social protest.

Bianka Vidonja Balanzategui is a casual academic at James Cook University, historian and historical consultant. She researches the sugar industry and migration history of tropical north Queensland, with published works such as Gentlemen of the Flashing Blade (JCU, 1990) and 'Basking in a Different Sun: The Story of Conchi Mendiolea' in Amatxi, Amuma, Amona: Writings in Honor of Basque Women (University of Nevada, 2003) marrying those two themes. She also has a keen personal and professional interest in the local history of the Herbert River Valley, north Queensland and her current research explores the contribution of women to that history.

Alexandra Wallis is a $\mathrm{PhD}$ candidate and sessional academic at the University of Notre Dame Australia, Fremantle. Her research focuses on the female patients' experiences at the Fremantle Lunatic Asylum from 1858 to 1908 . She graduated with a BA Hons in History and English from Edith Cowan University in 2014.

Elmarí Whyte was recently awarded her $\mathrm{PhD}$ at the University of Queensland. Her doctoral thesis considered the domestic service of white women in Australia and Britain from 1911 to 1951. 
